UNIVERSIDADE DE SÃO PAULO

FACULDADE DE FILOSOFIA, LETRAS E CIÊNCIAS HUMANAS DEPARTAMENTO DE HISTÓRIA

PROGRAMA DE PÓS-GRADUAÇÃO EM HISTÓRIA SOCIAL

Sandra Perez

\title{
Santo André: a invenção da cidade
}




\author{
UNIVERSIDADE DE SÃO PAULO \\ FACULDADE DE FILOSOFIA, LETRAS E CIÊNCIAS HUMANAS \\ DEPARTAMENTO DE HISTÓRIA \\ PROGRAMA DE PÓS-GRADUAÇÃO EM HISTÓRIA SOCIAL
}

\title{
Santo André: a invenção da cidade
}

Dissertação apresentada ao programa de Pós-Graduação em História Social do Departamento de História da Faculdade de Filosofia, Letras e Ciências Humanas da Universidade de São Paulo, para obtenção do título de Mestre em História Social

Orientadora: Prof. Dra Raquel Glezer

São Paulo 
Dedico esse trabalho à minha filha Sophia... 


\section{AGRADECIMENTOS}

À minha mãe, por cuidar da minha filha Sophia enquanto eu escrevia.

Ao meu marido pelo apoio nos momentos mais difíceis.

À minha amiga Saiury e à minha irmã Silvana pelo apoio nos momentos mais difíceis ao escrever essa dissertação.

Aos meus familiares - meu marido Maurício, meu pai, irmãos, cunhadas, sogra, sogro, tios e primos, pelas constantes palavras de incentivo.

Aos meus amigos que sempre estiveram presente em todas as fases da minha pesquisa: Meg, Saemi, Dida, Roseni, Anderson, Alexandre, Claudia, Rute e Sandra Felipe.

Aos meus amigos do departamento de História: Andrès, Renata, Rodrigo, Evelise, Rosana, Renato, Fernando e Magno e Marly.

À minha orientadora Prof ${ }^{a}$ dra Raquel Glezer.

Às bibliotecárias do Museu de Santo André pela dedicação e atenção, Melina e Márcia.

À Secretaria do Estado da Educação do Estado de São Paulo pela Bolsa de Mestrado. 


\section{RESUMO}

O objetivo dessa dissertação é estudar como ocorreu a formação e a cristalização da memória da cidade de Santo André, a partir de 1938, quando ocorreu a mudança da sede do município de São Bernardo para o distrito de Santo André. A partir desse momento, a elite intelectual da cidade, liderada pelo historiador Octaviano Gaiarsa, desenvolveu uma explicação para a origem da cidade, relacionando o município atual com a vila quinhentista de Santo André da Borda do Campo, que havia sido a primeira do planalto. Através dessa relação, a atual cidade de Santo André teve e tem a sua existência justificada, superando qualquer resistência à mudança de nome e de sede. Do mesmo processo fez parte a elaboração dos símbolos da cidade - hino, brasão e bandeira; a escolha do herói fundador, João Ramalho; a adoção da data de 8 de abril como aniversário da cidade, a criação dos lugares de memória - a Praça do Quarto Centenário, a construção de estátuas dos heróis quinhentistas e a adoção de seus nomes em ruas e bairros. Analisando a historiografia andreense e comparando-a com a paulista, produzida principalmente no Instituto Histórico e Geográfico de São Paulo, podemos indicar que a criação da memória da cidade de Santo André demonstra o uso político do passado.

Palavras Chave: Santo André, historiografia, memória, invenção da tradição. 


\begin{abstract}
In this thesis we study how the memory of a place can be built depending on the interests of the intellectual elite which lives there. We choose as an example the Santo Andre city (São Paulo), whose memory started to be created in 1938, when the headquarters of the São Bernardo do Campo city moved to there. From that time onwards, the intellectual elite of Santo André, led by historian Octaviano Gaiarsa, associated the origin of the city with the $16^{\text {th }}$ Century 'vila' of Santo André da Borda do Campo, the first one in the region. The existence of the city is nowand then justified by this relationship. Its symbols started to appear as part of the same process: anthem, emblem and flag, followed by the choice of its aniversary date, April $8^{\text {th }}$ and the hero which started the city, João Ramalho; memory public places were then built, like the Quarto Centenário Square, and statues were made to glorify its $16^{\text {th }}$ Century heroes; the name of the same heroes were chosen to be the names the streets and districts, and so on...

We finish the thesis using this analysis and the São Paulo city one, which can be found mainly in Instituto Histórico e Geográfico de São Paulo, to emphasize that the memory of a place is an example of the political use of the past.
\end{abstract}

Key words: Santo André, historiography, memory, invention of tradition. 


\section{LISTA DE ABREVIATURAS}

ABC - Abreviatura que designa as três cidades: Santo André, São Bernardo e São Caetano.

IHGB - Instituto Histórico e Geográfico Brasileiro.

IHGSP - Instituto Histórico e Geográfico de São Paulo. 
1 A INVENÇÃO DE UMA CIDADE: SANTO ANDRÉ 23

1.1Valorização de Santo André 32

1.2 João Ramalho - herói $\quad 39$

1.3Vitória de São Paulo $\quad 50$

1.4A "Fenix" renasce 52

2 SANTO ANDRÉ NA HISTORIOGRAFIA PAULISTA 59

2.1 Santo André $\quad 63$

2.2 A desvalorização de Santo André para justificar a mudança $\quad 72$

2.3 João Ramalho $\quad 79$

2.4 Continuidade entre as épocas 92

3 SANTO ANDRÉ NAS FONTES QUINHENTISTAS 96

3.1 Santo André $\quad 96$

3.2 Mudança de sede de vila para a casa dos jesuítas 105

$\begin{array}{ll}3.3 \text { João Ramalho } & 109\end{array}$

$\begin{array}{ll}\text { CONSIDERAÇÕES FINAIS } & 114\end{array}$

$\begin{array}{ll}\text { REFERÊNCIAS BIBLIOGRÁFICAS } & 118\end{array}$

$\begin{array}{ll}\text { ANEXOS } & 129\end{array}$

RELAÇÃO DE ILUSTRAÇõES

$\begin{array}{ll}\text { RELAÇÃO DE MAPAS } & 155\end{array}$ 


\section{INTRODUÇÃO}

O atual município de Santo André possui 172 quilômetros quadrados. Segundo o censo de 2009, a população estimada é de 673.396 habitantes. Sua taxa de alfabetização é de 95,9\% da população maior que 10 anos. $^{1}$ Seu desenvolvimento esteve atrelado ao processo de industrialização.

Sobre ele foram realizados vários trabalhos, nas mais diversas áreas (principalmente urbanização, movimentos sociais e meio ambiente) ${ }^{2}$, porém nenhum

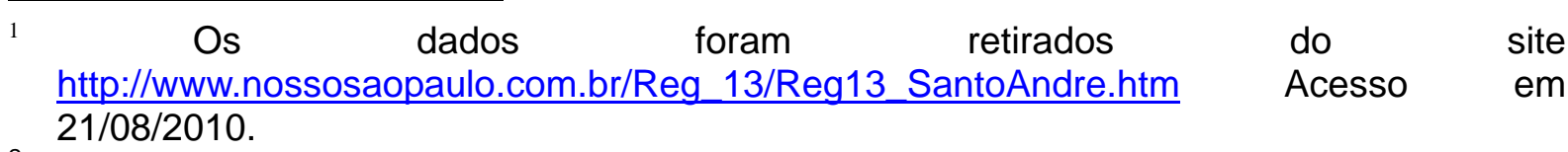

${ }^{2}$ Entre os muitos estudos sobre Santo André, destacamos: TIZIO, Ibere Luiz Di. Santo André: a causa toponímica na denominação de seus bairros. São Paulo: FFLCHUSP, 2009. Tese de doutorado (toponímia); XAVIER, Luiz Felipe. O canteiro é o banheiro, o desenho é a obra. São Paulo, 2009. Dissertação de mestrado (urbanismo); ARMELINI, Ângela Inês Micheletti da Silva Quintino. A preservação do patrimônio em Santo André: uma avaliação sobre a contribuição do uso cultural em imóveis tombados. São Paulo, 2008. Dissertação de mestrado (patrimônio arquitetônico); GUIDES, Fátima Regina Mônaco. Moradias urbanas em Santo André (1900-1950): caracterização da arquitetura popular e seus meios de produção. São Paulo, 2008. Dissertação de mestrado (moradia popular); CRISTIANINI, Adriana Cristina. Atlas semântico lexical da região do Grande ABC. São Paulo, 2007. Tese de doutorado (lingüística); CRUZ, Thais Fátima dos Santos. Paranapiacaba: a arquitetura e o urbanismo de uma vila ferroviária. São Carlos, 2007. Dissertação de mestrado (Paranapiacaba); PINHO, Rodrigo Altair. Santo André (re) ordenação sócio espacial e implicações do período técnico- científico- informacional a partir dos anos 90 . São Paulo, 2007. Dissertação de mestrado (espaço urbano); PULHEZ, Magaly Marques. Espaços de favela, fronteiras do ofício; histórias e experiências contemporâneas de arquitetos em assessorias de urbanização. São Carlos, 2007. Dissertação de mestrado (moradia popular); BLANCO JR, Cid. As transformações nas políticas habitacionais brasileiras nos anos 1990: o caso do programa integrado de inclusão social da Prefeitura de Santo André. São Carlos, 2006. Dissertação de mestrado (política habitacional); CARPIM, Thais Regina Pavez. Políticas públicas e ampliação de capital social em comunidades segregadas: o programa Santo André mais igual. São Paulo, 2005. Dissertação de mestrado (políticas públicas); CORREIA, Eduardo Luiz. A viagem interrompida. São Paulo, 2004. Dissertação de mestrado (história do Partido Comunista na região); História oral com participação comunitária. São Paulo: Annablume, 2004 (desenvolvimento econômico); Moradia social em áreas de mananciais. São Paulo: Annablume, 2004 (moradia popular); TERRAZAS, Marcelo (coordenação). Políticas de inclusão social de Santo André: Programa de apoio ás populações desfavorecidas, Programa Santo André mais igual. São Paulo: Projeto empreendedor popular: Banco do povo, 2004 (inclusão social); DENALDI, Rosana. Políticas de urbanização de favelas: evolução e impasses. São Paulo, 2003. Tese de doutorado (urbanismo); LOZANO, Márcia da Silva. A educação ambiental em uma escola do município de Santo André: análise situacional. São Paulo, 2003. Dissertação de mestrado (educação ambiental); MORAES, Maria Blassioli. A ação social católica e a luta operária: a experiência dos jovens operários católicos em Santo 
trabalho que se preocupasse em fazer análise historiográfica de Santo André e que procurasse entender como ainda hoje se mantém viva uma memória social criada em meados do século $X X$, que relaciona a cidade atual com a vila quinhentista de Santo André da Borda do Campo.

Ao observarmos o mapa do atual município e especialmente da cidade de Santo André, localizada no ABC paulista (Mapas 1 e 2), constatamos pouca semelhança com o da vila quinhentista de Santo André da Borda do Campo, embora a historiografia local coloque a continuidade entre os dois momentos como base de seu discurso.

No início do século XVI, até a fundação de Santo André da Borda do Campo, em 1553, quando Tomé de Souza elevou a povoação de João Ramalho à categoria de vila, exigindo, entre outras coisas, a construção de fortificação e trincheira com baluartes para artilharia, todas as terras do atual Grande ABC e do município de São Paulo eram parte da capitania e da vila de São Vicente (Mapa 3).

André (1954-1964). São Paulo, 2003. Dissertação de mestrado (movimento operário); SILVA, Rosângela Augusta. A qualidade dos mananciais e a inclusão social: a experiência de Santo André na gestão da Bacia Billings. São Paulo, 2003. Dissertação de mestrado (meio ambiente); UVINHA, Ricardo RICCI. Turismo de aventura: uma análise do desenvolvimento desse segmento na vila de Paranapiacaba. São Paulo, 2003. Tese de doutorado (turismo); SANTOS, Magda Carmo dos. Águas revoltas: história das enchentes em Santo André. Santo André: Santo André. Prefeitura municipal, 2002 (problemas urbanos); KULCSAR, Rosa. "O resgate da memória da Fundação Santo André" in Revista Fundação Santo André. V. 1., n. 1., p. 11/29, 2002 (Faculdade Fundação Santo André); SILVA, José Armando Pereira da. Guido Polanas: retratos da cidade. Santo André: Fundo de Cultura do município de Santo André, Secretaria de Cultura, Esporte e Lazer, 2002 (Museu de Santo André); RODRIGUES, Marly. Linhas e trajetos: história do serviço de transporte coletivo em Santo André. Santo André: Memórias, acessória e projetos, 2001 (transporte urbano); SilLVA, José Armando Pereira da. A cena brasileira em Santo André: 30 anos do teatro municipal. Santo André: Fundo de Cultura do Município de Santo André, 2001 (teatro municipal); NOGUEIRA, Bene. Trajetória imigrante, tempo de lembrar. Santo André: prefeitura, 2000 (imigração); $\mathrm{MEDICl}$, Ademir. Migração, urbanismo e cidadania: a história de Santo André contada pelos seus personagens. Santo André: Prefeitura Municipal de Santo André, 19-? (migração); Congresso de História da Região do Grande ABC. Santo André: Prefeitura do município de Santo André, 1990 (história da região). 

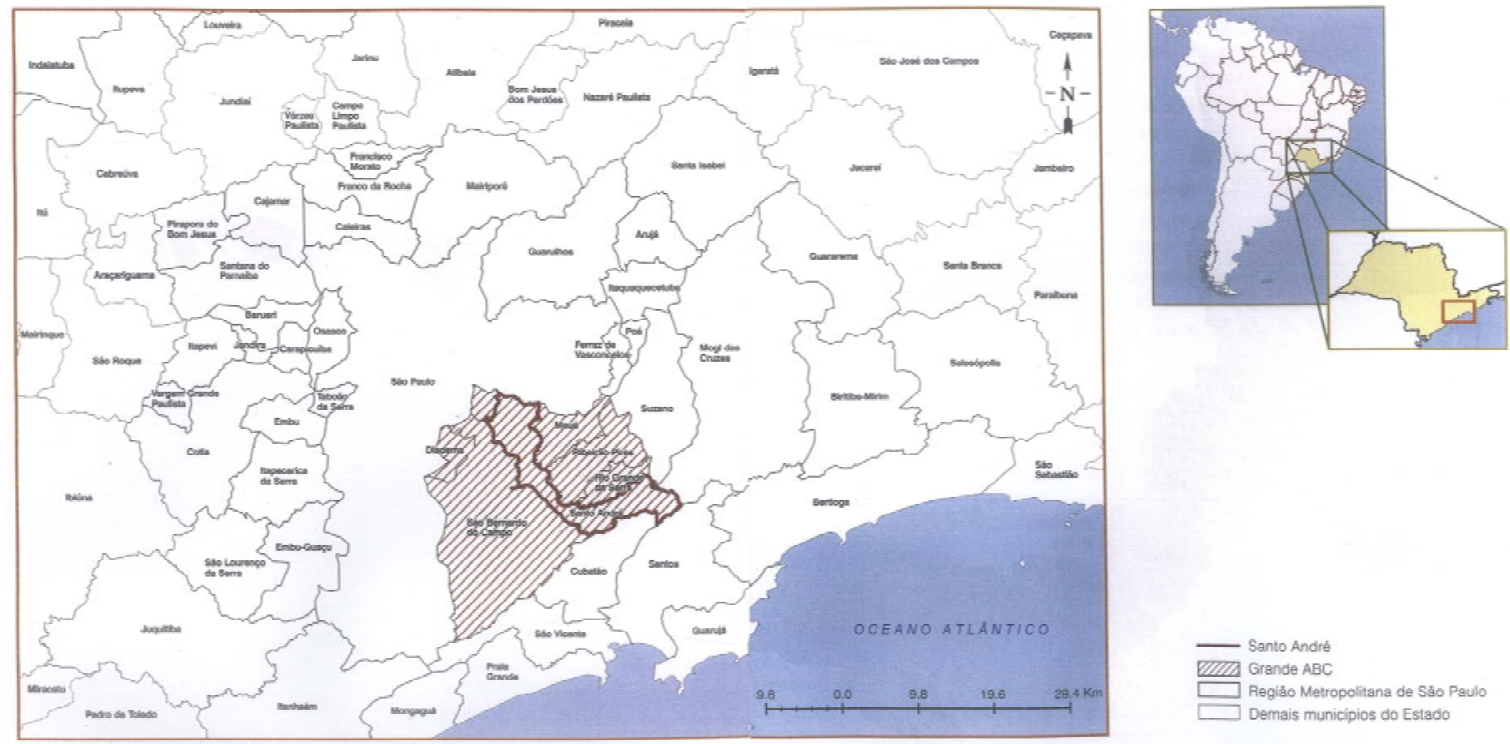

Mapa 1 - Contextualização de Santo André no Estado de São Paulo e no Brasil

(Sumário de Dados - 2008. Santo André: Prefeitura de Santo André, s/d, p.360/361)

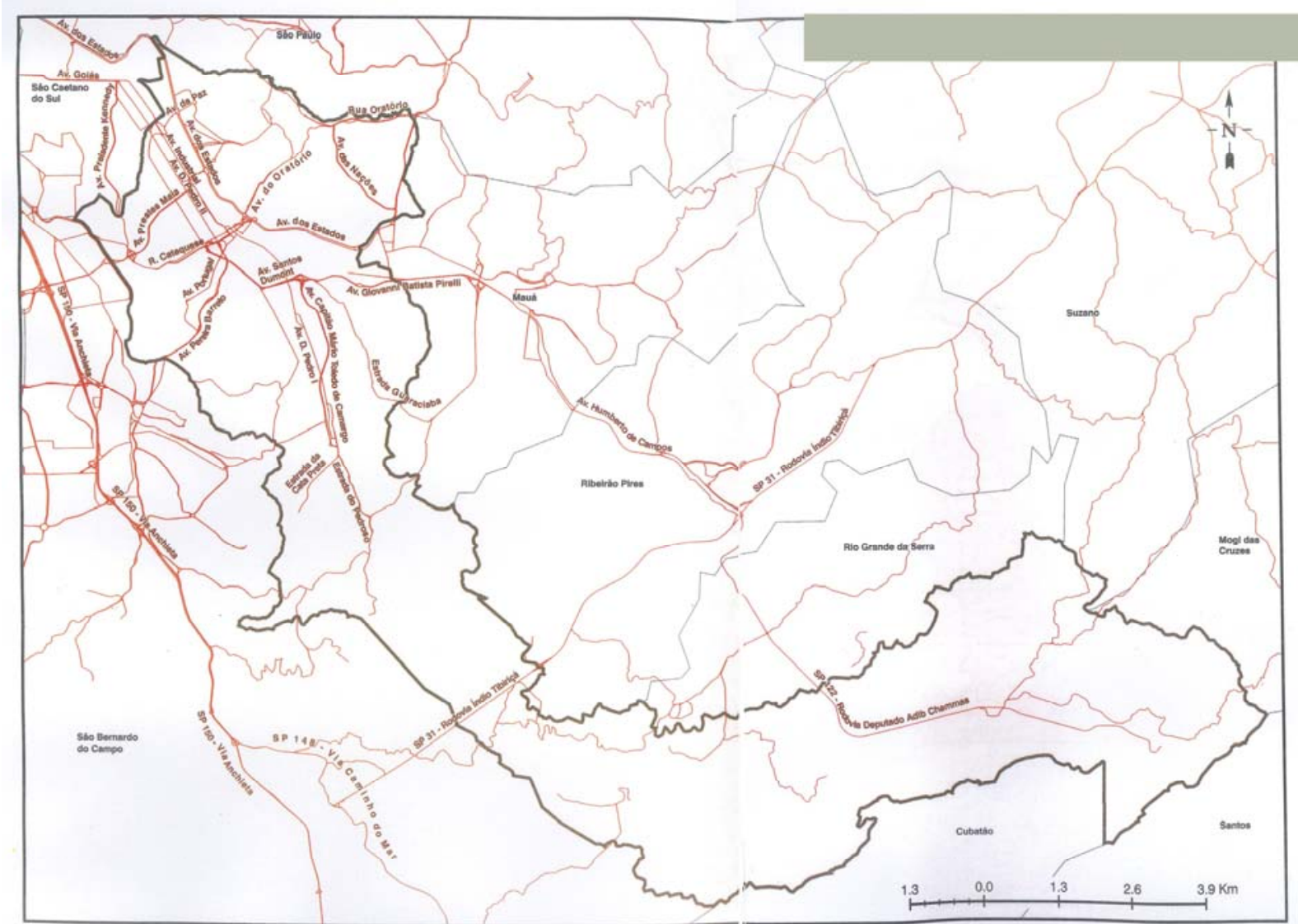

Mapa 2 - Principais vias de Santo André (Sumário de Dados - 2008, op.cit., p.366/367) 


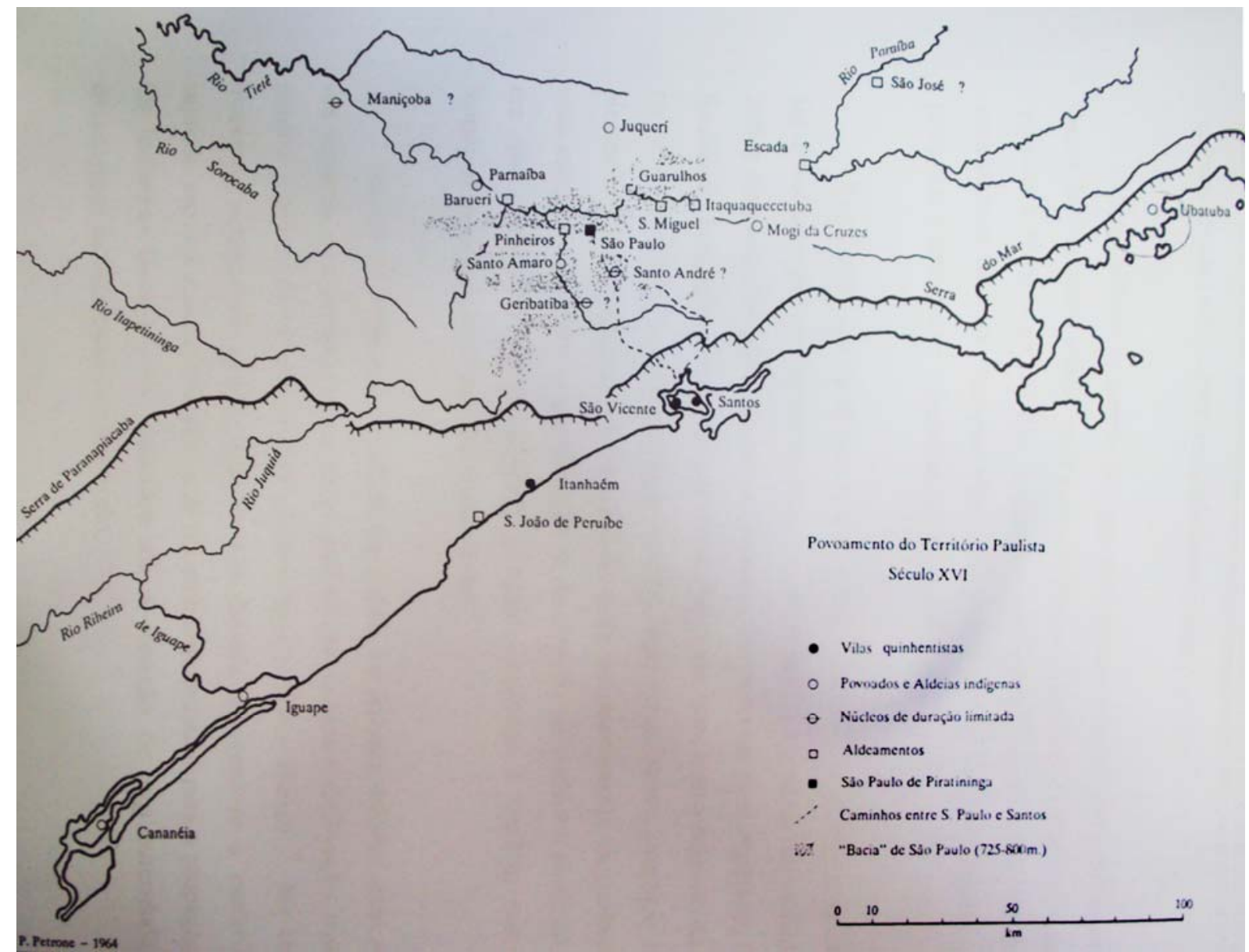

Mapa 3 - Povoamento do território paulista no século XVI (Petrone, Pasquale.

Aldeamentos Paulistas. SP:Edusp, 1995, p.47)

Pouco se sabe sobre a antiga povoação e a historiografia a respeito do assunto é controversa. Frei Gaspar da Madre de Deus ${ }^{3}$, por exemplo, afirma que a antiga povoação se assentava em terras da fazenda São Bernardo, pertencente ao mosteiro de São Bento. Manuel Eufrásio Azevedo Marques ${ }^{4}$ presume que a povoação tenha existido em local junto à antiga estação de trem de São Bernardo,

3 DE DEUS, Frei Gaspar da Madre. Memórias para a História da capitania de São Vicente, hoje chamada de São Paulo. São Paulo: Livraria Martins Fontes Editora S.A., s/ data.

4 MARQUES, Manuel Eufrásio de Azevedo (coligido por). Apontamentos Históricos, geográficos, biográficos, estatísticos e noticiosos da Província de São Paulo seguidos da cronologia dos acontecimentos mais notáveis desde a fundação da capitania de São Vicente até o ano de 1876. São Paulo: Livraria Martins Editora S.A., 1952. Tomo II. 
localizada próximo ao atual centro da cidade e para Teodoro Sampaio ${ }^{5}$, o local exato do antigo povoado ficava na interseção da Borda do Campo e do caminho primitivo aberto pelo gentio, correspondendo a pouco mais de um quilômetro para noroeste da vila de São Bernardo de sua época.

Outro ponto obscuro é referente á data da fundação da vila de Santo André da Borda do Campo. Conforme relatado por Frei Gaspar, ocorrera em 8 de abril de 1553, que corresponde a data em que o representante de Tomé de Souza subiu ao planalto e ergueu o pelourinho municipal. No entanto, Azevedo Marques e Affonso de E. Taunay ${ }^{6}$, afirmam que a data é 08 de setembro do mesmo ano.

A partir da criação do termo e da vila, os campos de Piratininga passaram para a vila de Santo André da Borda do Campo, desmembrando-se da vila de São Vicente e João Ramalho levantou o pelourinho, marco da inauguração da vila, e torna-se alcaide-mor ${ }^{7}$.

Pela sua posição geográfica, há a suposição que Santo André tivera um papel importante no desenvolvimento do território paulista, pois além de estar no caminho que ia para o Paraguai, controlava a passagem para o interior do território e também era uma feitoria importante de apresamento de índios.

Em 1554, um fato importante mudou o rumo da história da vila de Santo André: os jesuítas fundaram uma casa para servir de ponto de catequização dos índios no planalto, dentro da jurisdição de Santo André, próxima a aldeias indígenas, mas distante do povoado que era sede da vila.

Segundo Arlete Assumpção Monteiro ${ }^{8}$, a fundação da casa dos jesuítas, criou a "concorrência" (sic) entre João Ramalho e os religiosos e, com a mudança da rota para o Paraguai, tornou Santo André desnecessária ao governo português,

5 SAMPAIO, Teodoro. São Paulo nos século XIX e outros ciclos históricos. $2^{\mathrm{a}}$ edição. Petrópolis: Vozes; São Paulo: Secretaria da Cultura, ciência e tecnologia, 1978. Dimensões do Brasil, volume 11.

6 TAUNAY, Affonso de E. João Ramalho e Santo André da Borda do Campo. São Paulo: Revista dos Tribunais, 1968.

7 Segundo Joel SERRÃO alcaide é: "Palavra de origem árabe que designava, entre os muçulmanos da Península, o governador de uma praça ou de uma província. Entre os cristãos era apenas aplicada aos governadores de povoações fortificadas. O alcaide representava o rei e exercia, principalmente, funções militares, às quais se juntavam, por vezes, as administrativas e as judiciais. Mais tarde a palavra foi ligada a muitas outras funções, que nada tinham a ver com a função inicial". (Pequeno Dicionário da história de Portugal. Porto: Figueirinhas, 1993, p. 34).

8 MONTEIRO, Arlete Assumpção. Santo André: dos primórdios à industrialização. Um estudo sobre os imigrantes ao longo da SO Railway. São Paulo: FFLCH-USP, 1995. Tese de doutorado. 
impedindo o crescimento de Santo André e iniciou um movimento que levou à mudança de sede da vila para a área em que se localizava a casa dos jesuítas. Santo André passou a ser um bairro paulistano - o bairro rural da Borda do Campo.

Em 1560, o Governador Geral Mem de Sá decretou a mudança da sede da vila para próximo à aldeia indígena e casa dos jesuítas, ao mesmo tempo em que ordenou o fechamento do caminho que ia para o Paraguai passando pela vila de Santo André, com o argumento que o Caminho do padre José, recém criado, era mais seguro; os moradores de Santo André também deveriam se transferir para lá, incluindo João Ramalho.

A partir daí, a região da antiga sede da vila ficou esquecida até a edificação da capela de Nossa Senhora da Conceição da Boa Viagem, em 1735, que foi transformada em freguesia em 1812, com o nome de São Bernardo (Mapa 4). Com a construção da ferrovia entre Santos e Jundiaí - a São Paulo Railway, a região do planalto passou a ter várias paradas: Alto da Serra (Paranapiacaba), Campo Grande, Rio Grande, Ribeirão Pires, Pilar (Mauá), São Bernardo (atual Santo André) e São Caetano. 


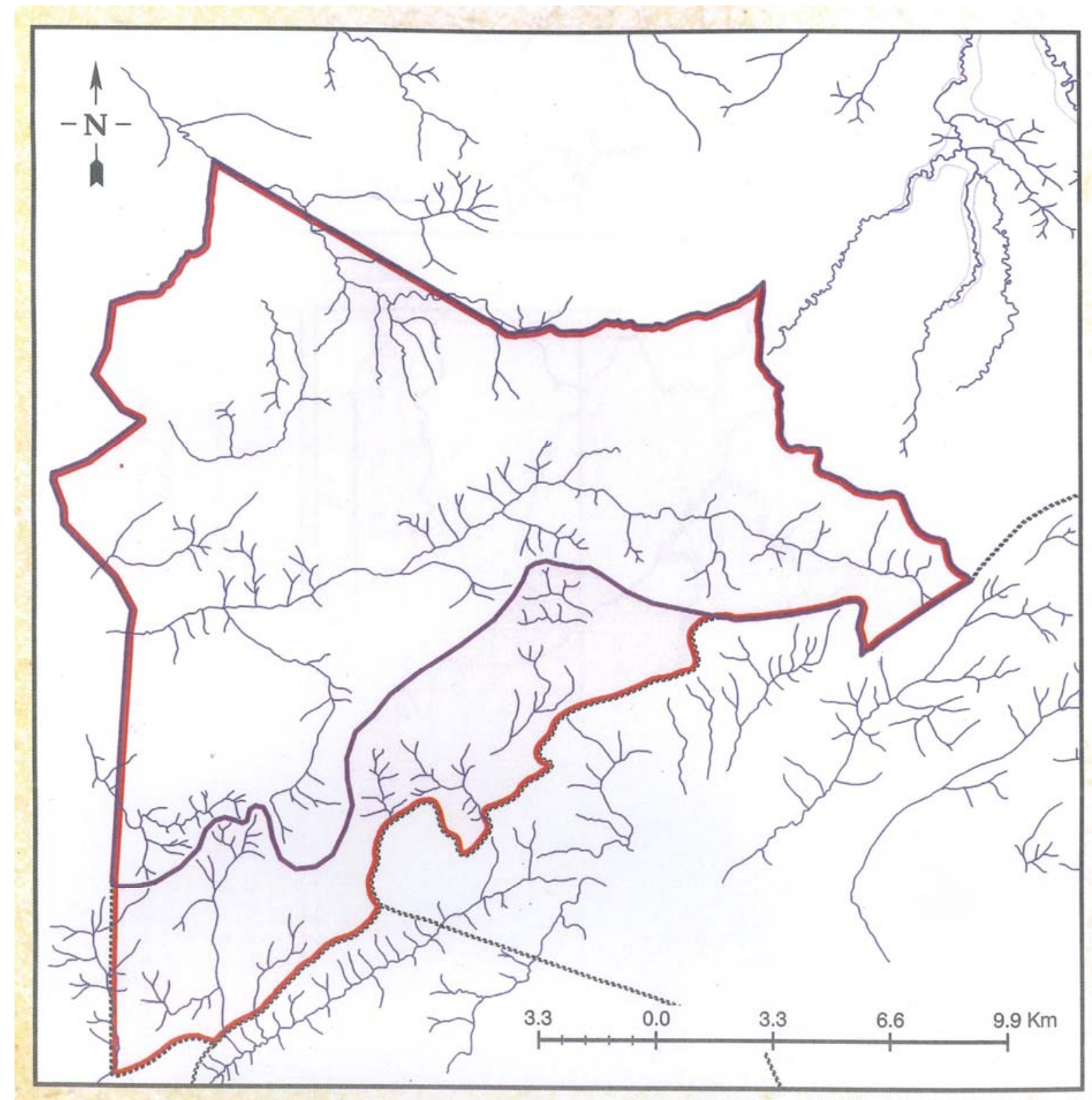

Mapa 4 - A freguesia de São Bernardo em 1832 (Sumário de Dados - 2008, op.cit., p.

348/349)

A autonomia do município de São Bernardo ocorreu em $1889^{9}$ e a sua instalação em 2 de maio de 1890 . Em $1938^{10}$, a sede do município mudou-se para a

9 A Lei n. 38 de 12 de março de 1889 elevou à categoria de município a freguesia de São Bernardo.

Disponível

em

http://www.al.sp.gov.br/portal/site/Internet/IntegraDDILEI?vgnextoid=2ddd0b9198067110V gnVCM100000590014acRCRD\&tipoNorma=9 Acesso em 18/08/2010.

10 O Decreto n. 9775 de 30 de novembro de 1938 "Fixa o novo quadro da divisão territorial do Estado que vigorará de 1 de janeiro de 1939 a 31 de dezembro de 1943 e dá outras providências". (Coleção das Leis e decretos do Estado de São Paulo. Volume 58 1938, Quarto Trimestre - Quarto Volume. São Paulo: Imprensa Oficial do Estado, 1939, p. 5). 
região da atual cidade de Santo André, e o nome passou a ser esse (Mapa 5). Segundo a Enciclopédia dos Municípios Brasileiros ${ }^{11}$, a justificativa para a mudança foi a que nessa região estavam localizadas as repartições públicas, os institutos de previdência e as maiores indústrias.

Segundo a Lei:

O Município de São Bernardo, que volta a sua antiga denominação de Santo André, fazendo-se a sede na povoação deste nome, constituído do distrito de paz da sede e dos de Mauá, Paranapiacaba, Ribeirão Pires e São Bernardo. ${ }^{12}$

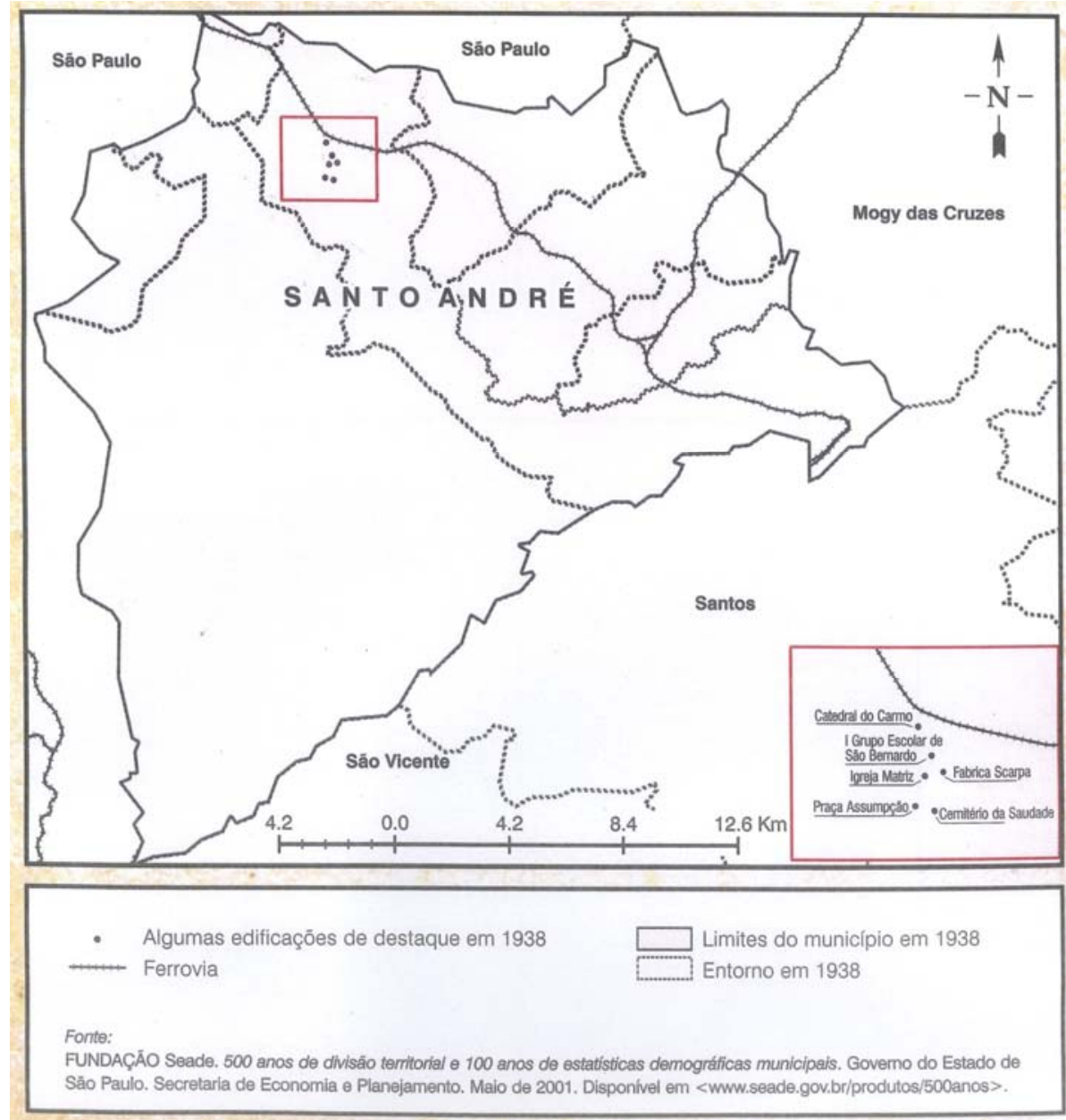

Mapa 5 - 1938 - oficialização do município de Santo André (Sumário de Dados, op.cit., p. 356)

${ }^{11}$ FERREIRA, Jurandyr Pires (orientador). Enciclopédia dos municípios brasileiros. Vol. XXX - São Paulo/RJ: IBGE, 1958.

12 Coleção das Leis e decretos do Estado de São Paulo. Volume 58, op. cit. pp. 321/324. 
Porém, segundo Wanderley dos Santos ${ }^{13}$, a maior influência para a mudança da sede veio da família Fláquer, de grande influência na região, que estava interessada em valorizar o bairro Tamanduateí, em que tinha uma propriedade denominada Santo André, e defendia que a sede da antiga povoação de Santo André da Borda do Campo localizava-se nas proximidades da estação ferroviária de São Bernardo.

Segundo o Dr. Fláquer, a escritura desse sítio confirmava que a

[...] denominação Santo André nunca deixou de designar a localidade [...] Os Fláquer, então, defendiam que o nome de Santo André fosse preservado através da nova povoação que se desenvolvia desde 1867 com a inauguração da ferrovia. Recordando: a estação ali inaugurada recebera o nome de São Bernardo. ${ }^{14}$

Para confirmar sua hipótese, o Dr. José Luiz Fláquer convidou alguns membros do IHGSP para visitarem a cidade em 1902. Porém, a conclusão do parecer do Instituto foi que a sede da vila de Santo André da Borda do Campo não era próxima à estação São Bernardo.

Para Wanderley dos Santos ${ }^{15}$, os moradores da nova povoação, ignorando esse parecer, pediram ao bispado licença para celebrar uma missa campal no local em que pretendiam construir uma igreja que se chamaria Santo André, perpetuando a memória do nome e a ligação com o passado quinhentista.

A igreja foi inaugurada em 1910, em terreno doado pelo coronel Alfredo Luiz Fláquer, irmão do senador José Luiz Fláquer. Os Fláquer conseguiram também a fundação de um distrito de paz junto à Estação São Bernardo. O distrito recebeu o nome de Santo André (Mapas 6 e 7) ${ }^{16}$.

Porém, tiveram que esperar mais 28 anos para a mudança de sede do município e do nome da cidade.

A partir de então, vários municípios da região do planalto paulista ganharam

13 SANTOS, Wanderley dos. Antecedentes históricos do ABC paulista. 1550-1892. Prefeitura do município de São Bernardo do Campo: SECE, 1992, p. 27

14 SANTOS, op. cit., p. 27.

15 SANTOS, op. cit., p. 27.

16 O distrito de Santo André foi criado pela Lei estadual n. 1222-A de 14 de dezembro de 1910. Segundo a Lei: "cria o distrito de paz de Santo André, com sede no povoado da estação de São Bernardo, da estrada de ferro ingleza, no município de São Bernardo". Disponível http://www.al.sp.gov.br/portal/site/Internet/IntegraDDILEl?vgnextoid=2ddd0b9198067110V gnVCM100000590014acRCRD\&tipoNorma=9 Acesso em 19/08/2010. 
autonomia. Em $1944^{17}$, foi o distrito de São Bernardo do Campo ${ }^{18}$, e São Caetano em $1948^{19}$. Finalmente, em 1953, os distritos de Ribeirão Pires e Mauá ${ }^{20}$ também $^{2}$ viraram municípios (Mapa 8).

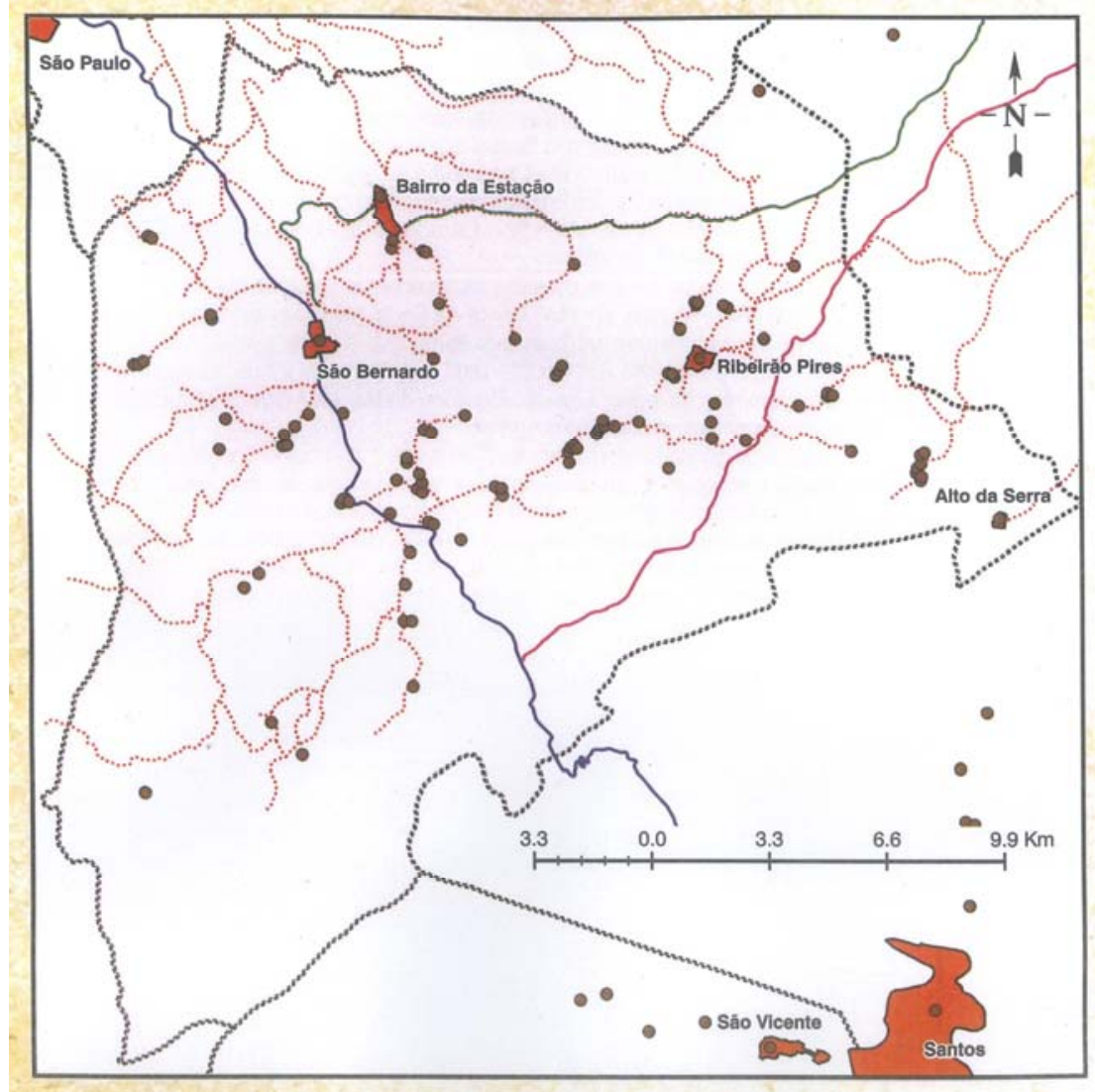

Mapa 6 - Núcleos urbanos e povoamentos no município de São Bernardo em 1906 (Sumário de Dados, op.cit., p.352/353)

17 Pelo Decreto-Lei n. 14334 de 30 de novembro de 1944 "fica fixada, de acordo com o presente decreto-lei, a divisão territorial do Estado que vigorará de primeiro de janeiro de 1945 a 31 de dezembro de 1948". (Coleção das Leis e decretos do Estado de São Paulo. Quarto Trimestre - Quarto Volume - 1944. São Paulo: Imprensa Oficial do Estado, 1945, p. 5).

18 As divisas do município de São Bernardo do Campo encontram-se na página 327 da Coleção das Leis e decretos do Estado de São Paulo. Quarto trimestre - Quarto Volume - 1944. Op. cit..

19 A Lei n. 233 de 24 de dezembro de 1948 "fixa o quadro territorial administrativo e judiciário do estado a vigorar no qüinqüênio 1949-1953". (Coleção das Leis e Decretos do Estado de São Paulo de 1948. Tomo 54. Quarto trimestre - Quinto Volume. São Paulo: Imprensa Oficial do Estado, 1949). As divisas do município de São Caetano do Sul encontram-se na página 393.

20 A Lei n. 2456 de 30 de dezembro de 1953 "Dispõe sobre o quadro territorial, administrativo e judicial do Estado para o qüinqüênio 1954/1958 e dá outras providências". (Coleção das leis e decretos do estado de São Paulo de 1553. Tomo 63. Quarto trimestre. Segundo Volume. São Paulo: Imprensa Oficial do Estado, 1954). As divisas do município de Mauá encontram-se na página 295 e as de Ribeirão Pires podem ser verificadas na página 408. 


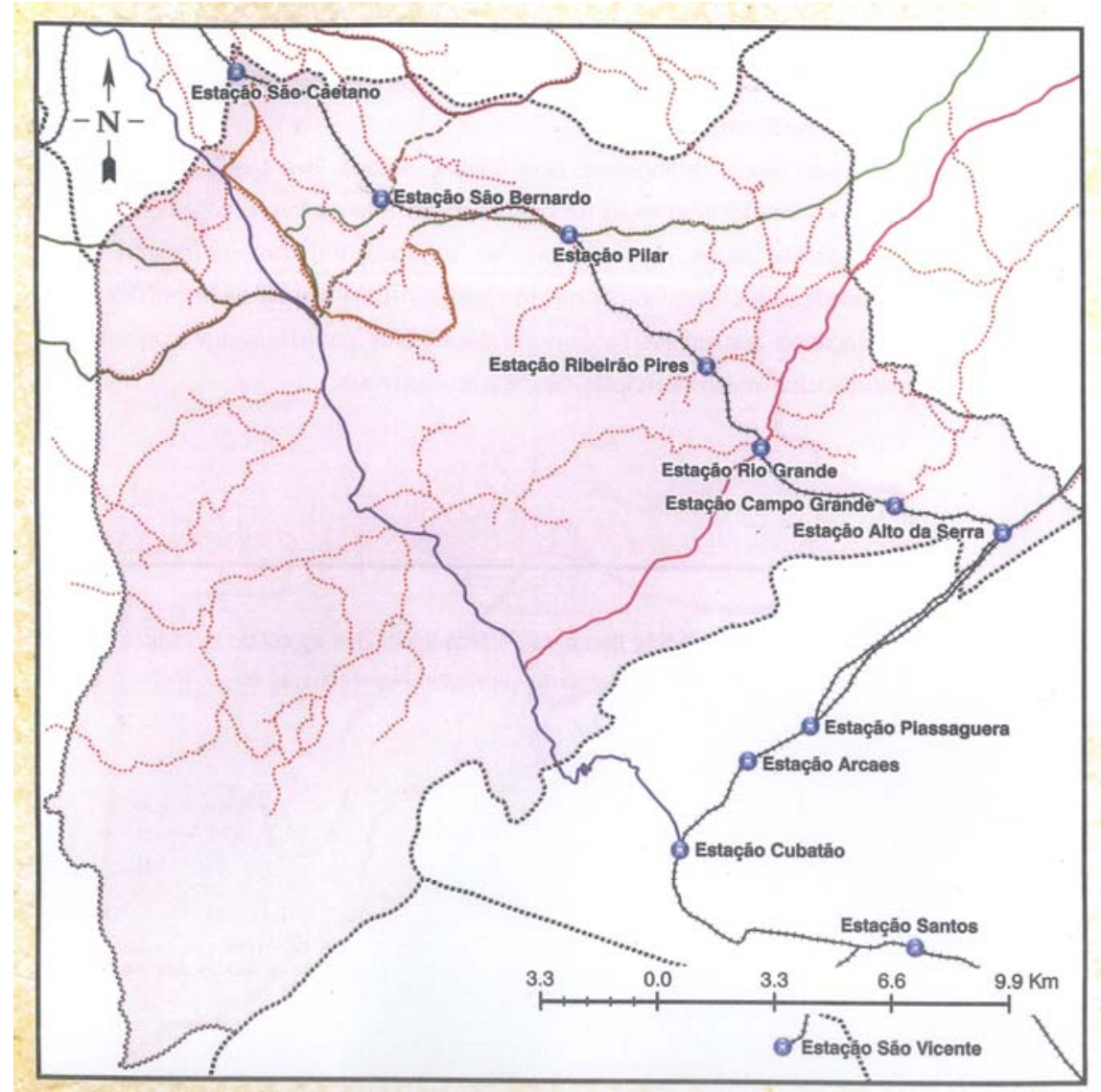

Mapa 7 - Estradas, caminhos e ferrovias no município de São Bernardo em 1906 (Sumário de Dados, op.cit., p.350/351)

Nesse mesmo ano Santo André vira comarca ${ }^{21}$, abrangendo, também, os municípios de Mauá e Ribeirão Pires.

Com a mudança da sede, torna-se necessário criar um elo de ligação entre as pessoas para a nova comunidade, permitindo que os seus habitantes possam imaginar-se como uma "comunidade política imaginada" ${ }^{22}$, principalmente a partir do momento em que diversos distritos foram transformados em municípios, fragmentando uma comunidade inicial.

Dada as constantes alterações nas demarcações territoriais e as discrepâncias existentes entre os autores, é fundamental resgatar como na construção da identidade coletiva da cidade de Santo André, a historiografia local solidificou uma determinada memória do passado, no caso específico, a da

${ }^{21}$ Coleção das leis e decretos do estado de São Paulo de 1553. Tomo 63. Quarto trimestre. Segundo Volume. São Paulo: Imprensa Oficial do Estado, 1954.

${ }^{22}$ ANDERSON, Benedict. Comunidades imaginadas. São Paulo: Companhia das Letras, 1991, p. 32. 
fundação da cidade e a do seu herói fundador, o que acentuou o descompasso entre o saber acadêmico e a invenção de um passado mítico.

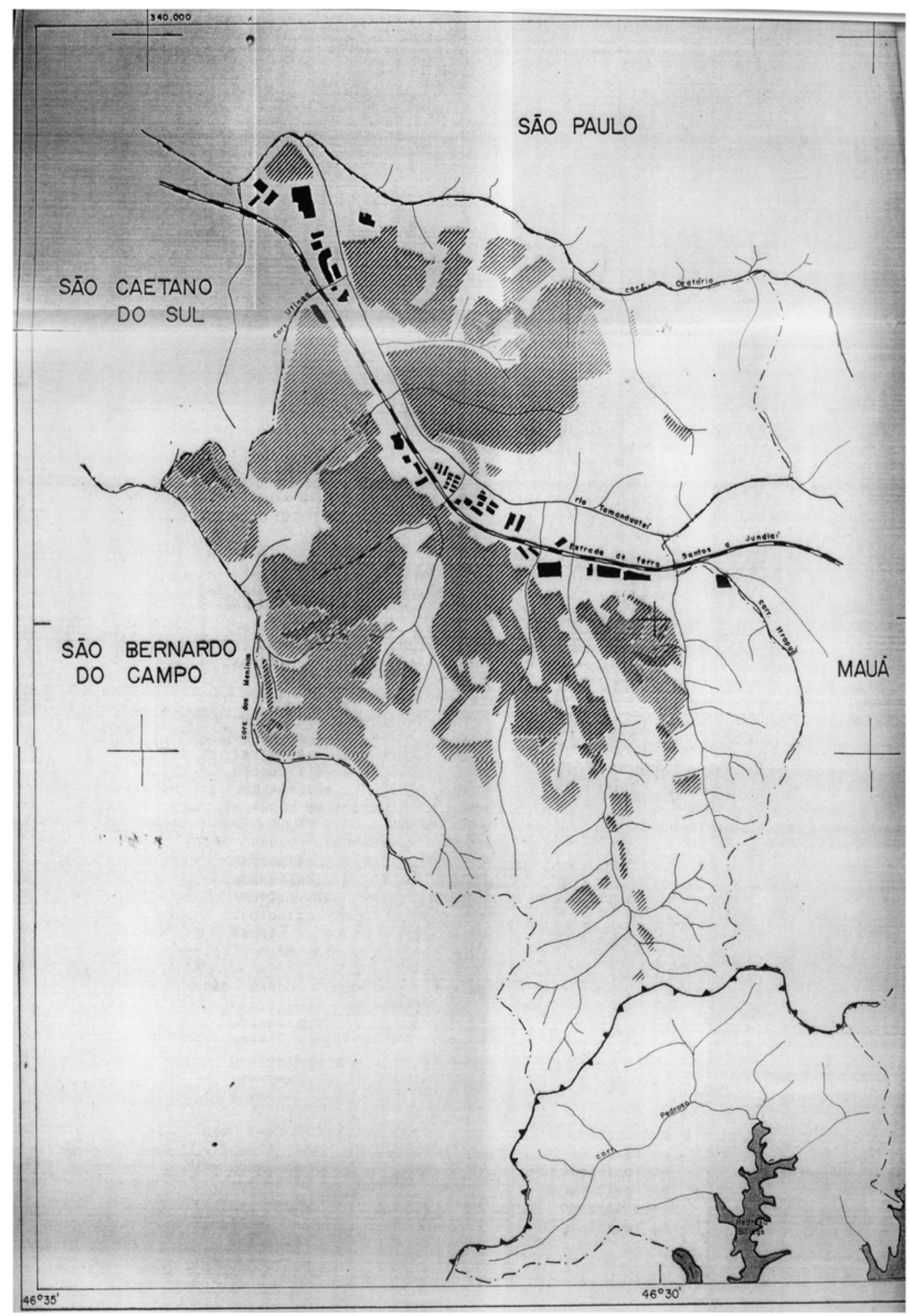

Mapa 8 - Santo André em 1954 (Passarelli, Silvia Helena F. Levantamento cartográfico de Santo André. SP: FAU/USP, 1993, p.21) 
Todo texto historiográfico é um discurso, uma representação do real, com uma ideologia e o objetivo desse trabalho é apresentar o processo da construção da memória social andreense.

Com o estudo das narrativas dos historiadores de Santo André e de São Paulo - produzidas com determinados fins ideológicos e que serviram para uma leitura crítica das "histórias das cidades", contadas pelas mesmas, com a forte marca da tradição inventada ${ }^{23}$ na construção da memória social de sua origem esse trabalho apresenta a construção da memória pela elite letrada andreense, a partir do século $X X$.

A escolha desse tema permitiu desconstruir a identidade cristalizada da cidade de Santo André, para a qual foi utilizada a historiografia para elaborar a memória sobre a origem, criando o seu passado. A "des-construção" desse discurso sobre a origem procurou mostrar o motivo que levou à cristalização da versão de Gaiarsa na memória oficial da cidade e como os autores posteriores repetiram a sua versão.

Segundo Pedro Ruiz Torres, ${ }^{24}$ tanto a identidade quanto a memória são construções históricas. Porém, apenas conhecemos e utilizamos uma parte do passado, a que se manteve como "souvenir", que foi "inventada", evocada a partir do contexto histórico do presente.

Um Estado, ao criar e manter uma identidade coletiva, apropria-se da História e da memória, faz um uso político do passado ${ }^{25}$ que permite manter a hegemonia dos grupos sociais no poder, apagando as outras memórias possíveis.

No caso das cidades, as identidades são construídas para encaixar-se na Nação ou na região e, conforme o papel a ser representado nessa relação, pela cidade, depende a organização desse discurso. Partindo desse pressuposto, a nosso ver, o historiador Gaiarsa - principal historiador sobre a história de Santo

23 Conceito desenvolvido por HOBSBAWM, Eric; RANGER, Terence na obra A invenção das tradições. São Paulo: paz e terra, 2006. $4^{a}$ edição e BANN, Stephen. As invenções da História. Ensaios sobre a representação do passado. São Paulo: Editora da Universidade Estadual Paulista, 1994.

${ }^{24}$ Segundo o autor: "(...) les identités ne sont pás de réalités qui préexistent et que nous pouvons découvrir ou reproduire de manière fidèle, mais elles ne sont pás non plus une pure fiction ou une simple invention (...)". (TORRES, Ruiz Pedro. "Les usages politiques de l'histoire em Espagne. Formes limites et contradictions" in HARTOG, François e REVEL, Jacques (org.). Les usages politiques du passe. Paris: Éditions de L'EHESS, 2001, p. 134)

25 TORRES, op. cit.. 
André - atrelou a história de Santo André a de São Paulo e a do Brasil, fazendo com que a cidade tivesse o bandeirante como fundador, e com o passado mais grandioso do que todas as outras cidades da região.

A dissertação divide-se em três capítulos. No primeiro, abordaremos a construção da memória da cidade de Santo André. Esse processo começou com a comemoração do quarto centenário da fundação da vila quinhentista, acompanhando as discussões da comemoração da cidade de São Paulo e foi sendo complementado com a criação do hino, da bandeira, do brasão, dos monumentos e da sua história oficial. Houve uma tentativa de mudança nesse discurso original que começou a partir da década de 1990, com a alteração do grupo político que controlava a prefeitura da cidade mas mantendo fortes traços da versão inicial.

No segundo capítulo, lemos os autores que serviram de referência para a historiografia loca I- os da historiografia paulista, que a partir do século XVIII, ao construir a história da cidade de São Paulo, procuraram desvalorizar Santo André para justificar a mudança de sede do município para junto à casa dos jesuítas, referindo-se, também, constantemente a João Ramalho, como herói ou vilão, conforme o caso.

No terceiro e último capítulo, partiremos para a análise das principais fontes quinhentistas que foram usadas, tanto pela historiografia paulista, quanto pela de Santo André, como Schmidel, as cartas jesuíticas, bem como as Atas da vila de Santo André da Borda do Campo e de São Paulo de Piratininga, entre outros.

Dessa forma, partindo da memória social cristalizada da cidade de Santo André, procuramos entender o seu processo de construção, partindo do presente, passando pela historiografia paulista e chegando às fontes quinhentistas.

Nessa dissertação irei manter a ortografia das fontes e da bibliografia tal como aparecem nas edições consultadas. 


\section{1 - SANTO ANDRÉ: A CRIAÇÃO DA MEMÓRIA}

Nesse capítulo estudamos a criação da memória do município e cidade de Santo André, por meio da argumentação de um passado heróico, relacionado com a de uma vila existente na região do planalto paulista no século XVI. Paralelamente a construção de uma história da cidade, houve toda uma elaboração da memória local, com a criação do hino, da bandeira, do brasão e do museu, com o objetivo de relacionar o presente com o passado.

A escolha da vila como a origem para a cidade atual foi motivada pela busca da mais antiga referência no período da América portuguesa na região da atual cidade e ela recaiu sobre a vila de Santo André da Borda do Campo, cujo nome coincide com o do distrito de Santo André, criado em 1910, para onde a sede da vila mudou-se em 1938.

Dessa forma, os autores da memória e da historiografia andreense começam uma polêmica com os da cidade de São Paulo para definir qual seria a mais antiga e, iniciado, portanto, a história de São Paulo e do Brasil.

A discussão passou a tentar definir, também, quem teria sido o primeiro "paulista", o "pai de todos" e chegaram a João Ramalho, que foi alcaide-mor da vila de Santo André. Daí a importância da atual cidade ser incontestável, pois além de ter sido a primeira no planalto, ela tinha como figura central e criador o "pai dos paulistas".

Restaram poucas fontes relacionadas a essa vila, o que originou muita polêmica e fantasias a seu respeito, tanto na historiografia ligada à cidade de São Paulo, quanto na da cidade de Santo André.

Como atesta Ruiz Pedro Torres ${ }^{26}$, um Estado manipula a história e forja uma memória para criar e manter uma determinada identidade coletiva e é dessa forma que entendemos a relação entre a vila de Santo André e a atual cidade. Segundo o autor citado, este é um dos usos políticos do passado, que permite manter a hegemonia de determinados grupos sociais no poder.

Podemos perceber tal uso político ao estudarmos a criação da memória da cidade de Santo André, a partir do momento em que houve a mudança de sede do

${ }^{26}$ Ibid., p. 135. 
município para o distrito de Santo André, em 1938, quando escritores e historiadores da nova cidade buscaram criar uma origem gloriosa no período colonial, cujo fundador - João Ramalho era o maior ancestral dos paulistas. Dessa forma, a cidade atual passava a ter a sua existência garantida através desse passado heróico.

Para compreender o processo de criação da memória e da história local, utilizaremos diversas fontes. Assim, veremos como João Ramalho e a vila quinhentista de Santo André da Borda do Campo apareceram na obra de Octaviano Gaiarsa, historiador especializado na história do município, nos textos dos documentos oficiais da Prefeitura de Santo André, encontrados nos sites da Prefeitura e da Câmara Municipal, no curso sobre a história local, oferecido pelo Museu Dr. Octaviano Armando Gaiarsa ${ }^{27}$ para os professores da rede pública de ensino, bem como nos símbolos da cidade - hino, bandeira e brasão -, em jornais, em documentos literários, como a peça teatral $\mathbf{A}$ cidade assassinada ${ }^{28}$ de Antonio Callado e poemas.

A criação da memória da cidade caminhou junto com a criação dos seus lugares de memória e a elaboração da história local, a partir da década de 1950. Nora define que os lugares de memória são construções. Dessa forma,

Os lugares da memória nascem e vivem do sentimento que não existe memória espontânea, que é preciso criar arquivos, que é preciso manter os aniversários, organizar as celebrações, pronunciar as honras fúnebres, estabelecer contratos, porque estas operações não são naturais. ${ }^{29}$

Segundo Jacques Le Goff ${ }^{30}$, a memória é um dos elementos chave para a construção da identidade coletiva de um povo e a sua criação é o resultado da

${ }^{27}$ O projeto de criação de um museu em Santo André teve origem na década de 1950. Em 1974 a Secretaria de Educação, Cultura e Esporte do município desenvolveu uma campanha denominada "Nosso passado pode estar com você", visando dar impulso à formação do museu. Porém, somente em 1981 foi criada a Comissão Organizadora do Museu que elaborou a Lei n. ${ }^{05.942}$ de 03 de agosto de 1982, criando-o efetivamente. Em 2005, passa a chamar-se Museu Dr. Octaviano Gaiarsa. Consulta em http://www.santoandre.sp.gov.br/pop up noticia.asp?cod=6358. Acesso em 17/05/2010.

${ }^{28}$ CALLADO, Antonio. A cidade assassinada. Santo André. DEC, s.d., p. 81.

${ }^{29}$ NORA, Pierre. "Présentation/ La Fin de l'Histoire-Mémoire" in Les Lieux de Mémoire. Vol.1. Paris: Gallimard, 1984, p. XXIV.

${ }^{30}$ GOFF, Jacques Le. "Memória" in Enciclopédia Einaudi. Volume 1. Memória-História, p. 46. 
busca de legitimidade da elite política local. Assim, no caso de Santo André, a elite, vitoriosa com a mudança da sede do município, passou a se preocupar em construir sua versão a respeito da fundação da cidade, criando uma continuidade com a vila de Santo André da Borda do Campo, de cujo nome apropriou-se, por meio da solidificação de determinada memória a respeito da origem, justificando sua existência e inventando, dessa forma, um passado heróico.

Para Catogra, na construção da história de uma região, é fundamental inventar "[...] mitos de origem (ou de refundação), símbolos, heróis (individuais e coletivos) e ritos [...]" 31

A criação da memória de Santo André não fugiu dessa mesma elaboração. Podemos perceber tal preocupação na peça teatral $\mathbf{A}$ cidade assassinada ${ }^{32}$ de Antonio Callado ${ }^{33}$, publicada em 1954, que é uma das primeiras obras que buscou colocar a história de Santo André em seu próprio olhar e não no de São Paulo, a partir do momento em que procurou "inventar" a vida no que teria sido a vila quinhentista. Nessa época havia uma disputa entre as duas cidades para comprovar a qual caberia o pioneirismo no planalto, a partir do momento que ambas estavam comemorando os seus quatrocentos anos. O nome da peça não deixa de ser interessante, pois indica justamente uma reação a fundação de São Paulo, a partir do momento que a sua origem teria significado a morte do povoado "rival" de Santo André.

31 CATROGA, Fernando. Nação, mito e rito. Fortaleza: Edições NUDOC/Museu do Ceará, 2005, p. 16.

32 CALLADO, op. cit.

33 Antonio Callado (1917/1977) formou-se em direito em 1939, porém, acabou exercendo a função de jornalista em diversos jornais a partir de 1937: repórter, cronista e redatorchefe no Correio da Manhã; redator na BBC de Londres; trabalhou no serviço brasileiro da Radio-Diffusion Française, em Paris; colaborador em O Globo; redator do Jornal do Brasil e colunista da Folha de S. Paulo. Participou também da elaboração da Enciclopédia Barsa, publicada em 1963. A partir de 1974, iniciou a carreira acadêmica como Visiting Scholar em Corpus Christi College, na Universidade de Cambridge, Inglaterra. E, em 1981, passou o segundo semestre lecionando, como Visiting Professor, na Columbia University, Nova York. Aposentou-se como jornalista em 1975, mas continuou a colaborar na imprensa. Além das atividades jornalísticas, dedicou-se sempre à literatura. Nessa dissertação iremos trabalhar com a sua peça teatral A cidade assassinada. Sua biografia está disponível nos sites: http://biografias.netsaber.com.br/ver biografia c 4108.html. Acesso em 30/07/2010 e http://www.academia.org. br/abl/cgi/cgilua. exe/sys/start.htm?infoid=152\&sid=138\&tpl=print erview. Acesso em 30/07/2010. 
Partindo das discussões presentes na historiografia paulista, Antonio Callado elaborou um passado para a vila quinhentista, humanizando os personagens históricos, que antes eram apenas nomes, criando uma história para tais pessoas, construindo, também, uma versão para justificar a mudança da sede para próximo à casa dos jesuítas.

Octaviano Armando Gaiarsa ${ }^{34}$, responsável pela criação da história, brasão e bandeira da cidade, nasceu em 1911, neto de imigrantes italianos e filho do dono da fábrica de colchas e cobertores Alfredo Fláquer \& Cia. Fez o curso primário no I Grupo Escolar, local que atualmente é a sede do Museu (Foto 1). Médico formado em 1937, exerceu a profissão durante 32 anos. Foi também vereador pela UDN entre 1948 e 1951. Em 1952, entrou para o serviço público no departamento de saúde e assistência social, tendo exercido vários cargos burocráticos, entre eles, chefe do serviço social.

Durante o mandato de três prefeitos foi encarregado de dar denominações a centenas de vias públicas e publicou em 1953 o primeiro Guia de ruas da cidade, fazendo também parte da Comissão dos festejos do $4^{\circ}$ centenário de Santo André, no ano de 1553. Em 1972, no mandato do Dr. Newton da Costa Brandão, reformulou inteiramente os símbolos municipais - bandeira e brasão.

Além de ter escrito aproximadamente 600 artigos para o jornal 0 repórter, era também membro honorário do Instituto Histórico e Geográfico de São Paulo IHGSP, partindo daí a relação com os historiadores dessa instituição.

O presente trabalho analisou duas de suas obras sobre a história da cidade. A primeira $^{35}$, A cidade que dormiu três séculos (Santo André da Borda do Campo; seus primórdios e sua evolução histórica: 1553 - 1960), editada em 1968, época da prefeitura de Fioravante Zampol $^{36}$, e a segunda ${ }^{37}$, Santo André: Ontem, Hoje e

${ }^{34}$ Consulta disponível em http://www.santoandre.sp.gov.br/pop up noticia.asp?cod=6358 Acesso em 30/07/2010.

${ }^{35}$ GAIARSA, Octaviano. A cidade que dormiu três séculos (Santo André da Borda do Campo; seus primórdios e sua evolução histórica: 1553- 1960). Santo André: Tipografia Bandeirante Ltda São Paulo, 1968. Primeira Edição.

${ }^{36}$ Fioravante Zampol (1908/1977) ingressou na política em Ribeirão Pires, como subprefeito do distrito de Ribeirão Pires de 1933 a 1935, quando foi nomeado membro do Conselho Consultivo Municipal. Foi vereador duas vezes: entre 1936 e 1937 - quando as Câmaras Municipais foram extintas - e entre 1947 e 1951. Tomou posse como prefeito pelo PSP em 1952, exercendo o cargo até 1955, quando assumiu cadeira de deputado na Assembléia Legislativa de São Paulo. Em 1964, foi empossado no cargo de vice-prefeito e tornou-se prefeito com a morte de Lauro Gomes de Almeida em 1964. Foi responsável pela criação da Faculdade Fundação de Santo André. Sua biografia está disponível nos 
Amanhã, que é uma revisão da primeira, foi editada em 1991, na prefeitura de Celso Daniel $^{38}$. Nessas duas obras o autor usou como fontes os inventários e os cronistas do período colonial, além de ter como referência principal, o historiador Taunay e os autores do Instituto Histórico e Geográfico de São Paulo.

Em ambas as obras, Gaiarsa defende que o historiador pode chegar a uma verdade absoluta sobre o passado, construindo uma obra fiel à realidade, escrevendo uma longa crônica como se estivesse presente em cada época descrita.

Vale salientar que a partir de 1991, houve uma busca de novas maneiras de explicar a história do município, as quais nem sempre conseguiram fugir da versão inicial de Gaiarsa, conforme podemos observar nos textos sobre a história da cidade que estão nos sites da Prefeitura, da Câmara dos Vereadores e no Curso de História da cidade do Museu local.

sites: http://augus54.wordpress.com/os-prefeitos. Acesso em 31/7/10; http://dicionarioandreensedepersonalidades.blogspot.com/2009/03/zampol-familia-emandamento 21.html. Acesso em 31/7/10 e MARCELLOS, Lincoln Nogueira. Desenvolvimento regional e identidade industrial: a faculdade de ciências econômicas e administrativas de Santo André (1950-1960). Dissertação de Mestrado em Administração. São Caetano do Sul: IMES, 2006. Disponível em http://www.uscs.edu.br/posstricto/administracao/dissertacoes/2006/lincoln marcellos/diss ertacao lincoln marcellos.pdf. Acesso em 31/07/2010.

${ }^{37}$ GAIARSA, O. Santo André: Ontem, Hoje e Amanhã. Santo André, São Paulo: Prefeitura municipal de Santo André, 1991.

38 Celso Augusto Daniel (1951/2002) foi prefeito de Santo André por oito anos (entre 1989 e 1992 e 1997 a 2002). Engenheiro civil, mestre em administração e doutorado em Ciências Políticas, era professor de Economia na PUC e no departamento de Ciências Sociais da FGV. Foi um dos fundadores do PT em Santo André e lançou-se na política em 1982, concorrendo à Prefeitura da cidade, quando foi derrotado por Newton Brandão. Porém, em 1989, conseguiu sua primeira eleição para o Executivo andreense. Em 1994, foi eleito para a Câmara dos Deputados e durante seu mandato, atuou na Comissão de Reforma Tributária e Fiscal da Câmara. Em 1997, volta à Prefeitura de Santo André. Celso Daniel representou Santo André e o Brasil em junho de 2001 na Conferência Mundial em Istambul. Ele também era diretor-geral da Agência de Desenvolvimento Econômico do Grande $A B C$ e fundador do Consórcio Intermunicipal do Grande ABC, composto pelos sete prefeitos da região. Celso Daniel presidiu o Consórcio nos anos de 1991, 1992 e 1997. Foi encontrado morto em janeiro de 2002. Sua biografia está disponível nos sites: http://amigoscelsodaniel.blogspot.com/2007/09/biografia.html Acesso $\quad$ em 30/07/2010 e http://dicionarioandreensedepersonalidades.blogspot.com/2009/03/zampol-familia-emandamento 21.html Acesso em 30/07/2010. 


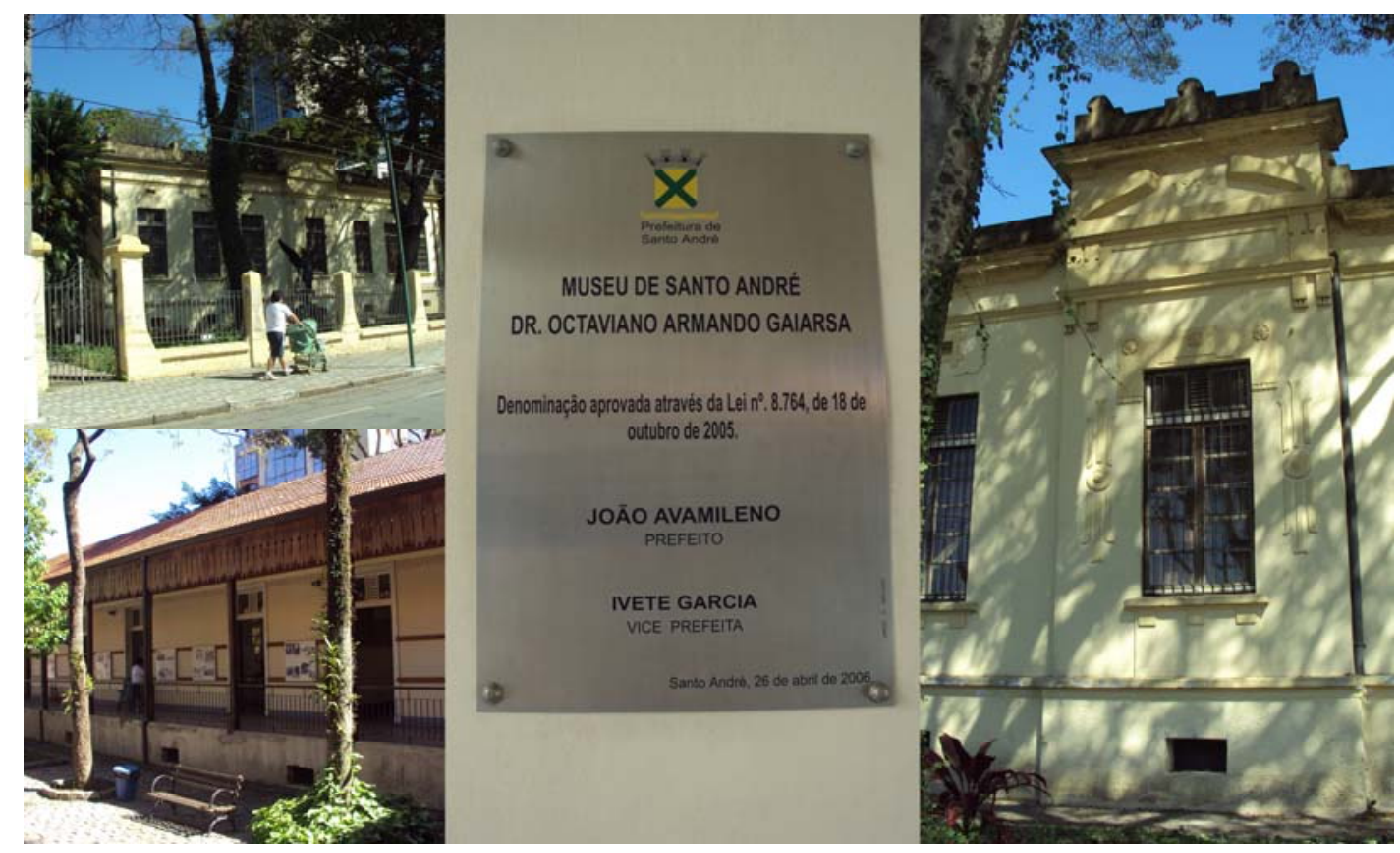

Foto 1 - Montagem de fotos do Museu Dr Octaviano Armando Gaiarsa (Arquivo pessoal)

Em 1950, paralelamente à invenção da origem da cidade, houve a elaboração do que Nora definiu como sendo os lugares de memória, a partir do momento em que:

[...] são lugares, de fato, nos três sentidos da palavra: material, simbólico e funcional, mas, simultameamente em graus diversos. Mesmo um lugar de aparência puramente material, como um depósito de arquivos, não é lugar de memória se a imaginação o investe de uma aura simbólica. [...] Mesmo um minuto de silêncio, que parece o extremo de uma significação simbólica, é, ao mesmo tempo, um corte material de uma unidade temporal e serve, periodicamente, a um lembrete concentrado de lembrar. Os três aspectos coexistem sempre. ${ }^{39}$

No caso que estudamos, foi criada uma Comissão Geral dos festejos do IV Centenário da fundação de Santo André da Borda do Campo, com o objetivo de erigir um monumento a João Ramalho organizar um museu, além da construção do Complexo do Quarto Centenário ${ }^{40}$ (Foto 2). Em 1954, com a finalização das

${ }^{39}$ NORA, op. cit., p. 34 e 35.

${ }^{40}$ Projetado pelo arquiteto Rino Levi e inaugurado como parte das celebrações do quarto centenário de Santo André, abriga a Prefeitura, a Câmara Municipal, um fórum estadual, uma biblioteca e o teatro municipal. Consulta disponível em http://wikimapia.org/37983/pt/Pra\%C3\%A7a-Quarto-Centen\%C3\%A1rio. Acesso em 31/07/2010. 
comemorações, foi criada a Biblioteca Municipal e o projeto do Museu ficou apenas no papel.

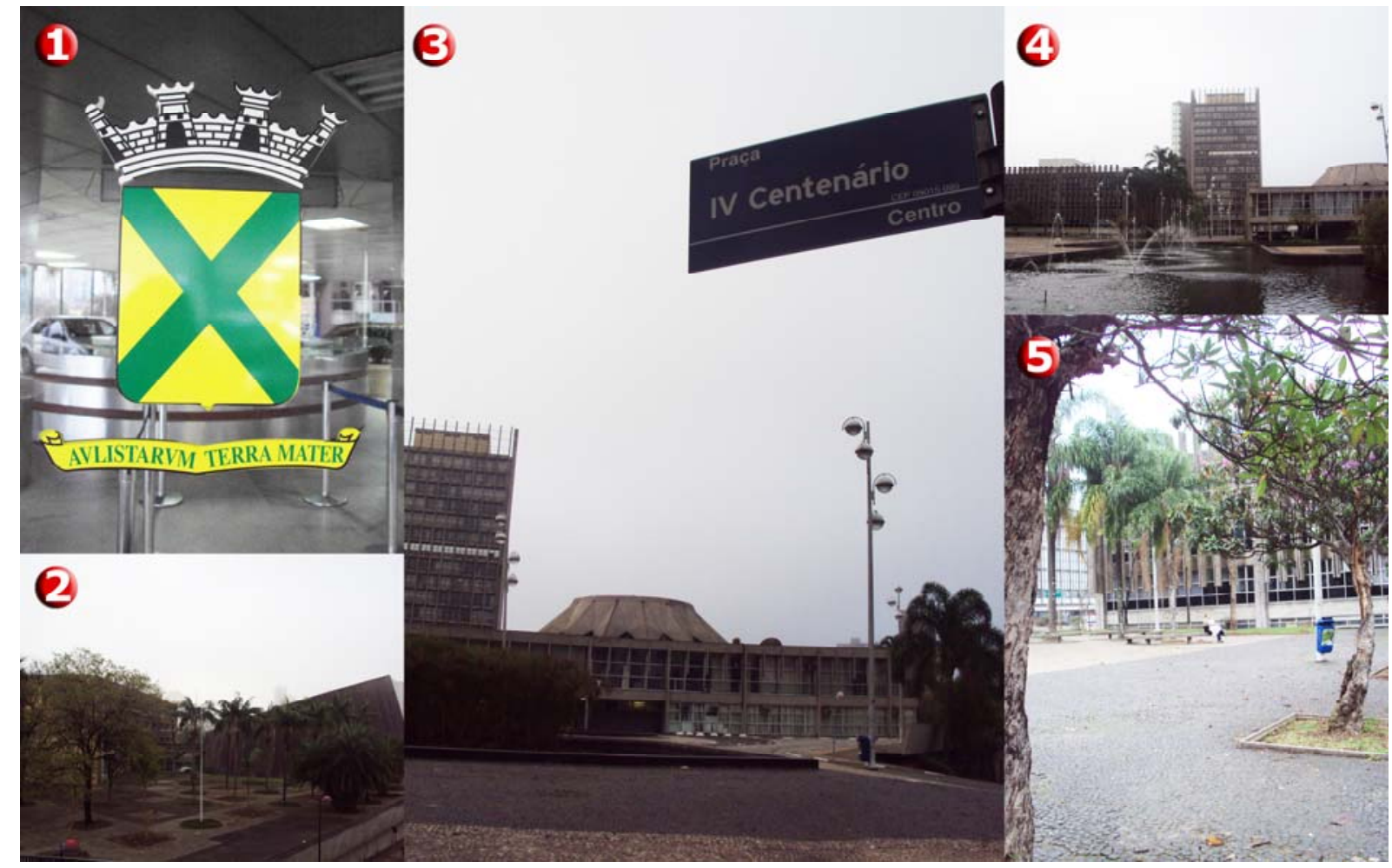

Foto 2 - Montagem de fotos sobre o Complexo Quarto Centenário: 1 - Brasão em frente da Câmara Municipal; 2 - Teatro e biblioteca; 3 - Vista geral do Complexo; 4 - Fórum, Prefeitura e Câmara; 5 - Vista da praça (Arquivo pessoal)

A finalização desse processo foi a comemoração da festa cívica do aniversário da cidade em 8 de abril, uma menção à fundação da vila quinhentista de Santo André da Borda do Campo, confirmando o elo entre as duas épocas.

Para essa comemoração foram organizadas várias exposições durante o decorrer do ano de 1553: de selos, de flores, o I Salão Internacional de Arte Fotográfica e a Industrial. Dessa última, resultou um catálogo ${ }^{41}$, cuja capa podemos visualizar na foto 3. Nesse mesmo ano são inauguradas a Nova Matriz da cidade e o Hospital Municipal, além de ter sido realizado o Concurso de Miss Centenário no Club Atlético Rhodia. As instalações do Correio também foram ampliadas.

41 PATERNOSTRO Filho, Luiz (direção técnica geral). Catálogo Oficial da Exposição Industrial do IV centenário da fundação de Santo André da Borda do Campo. 1553/1953. São Paulo: Empresa Editora Cicerone Ltda, 1953. 
Os jornais da época ${ }^{42}$ não se cansaram de publicar artigos sobre a comemoração. As reportagens iam desde a história da cidade, passando por João Ramalho e as exposições e inaugurações do ano.

A Exposição Industrial realça a importância atribuída às indústrias, o que resultou na criação da imagem da cidade de Santo André como sendo a de um "viveiro industrial", fonte de todo o progresso e prosperidade da região.

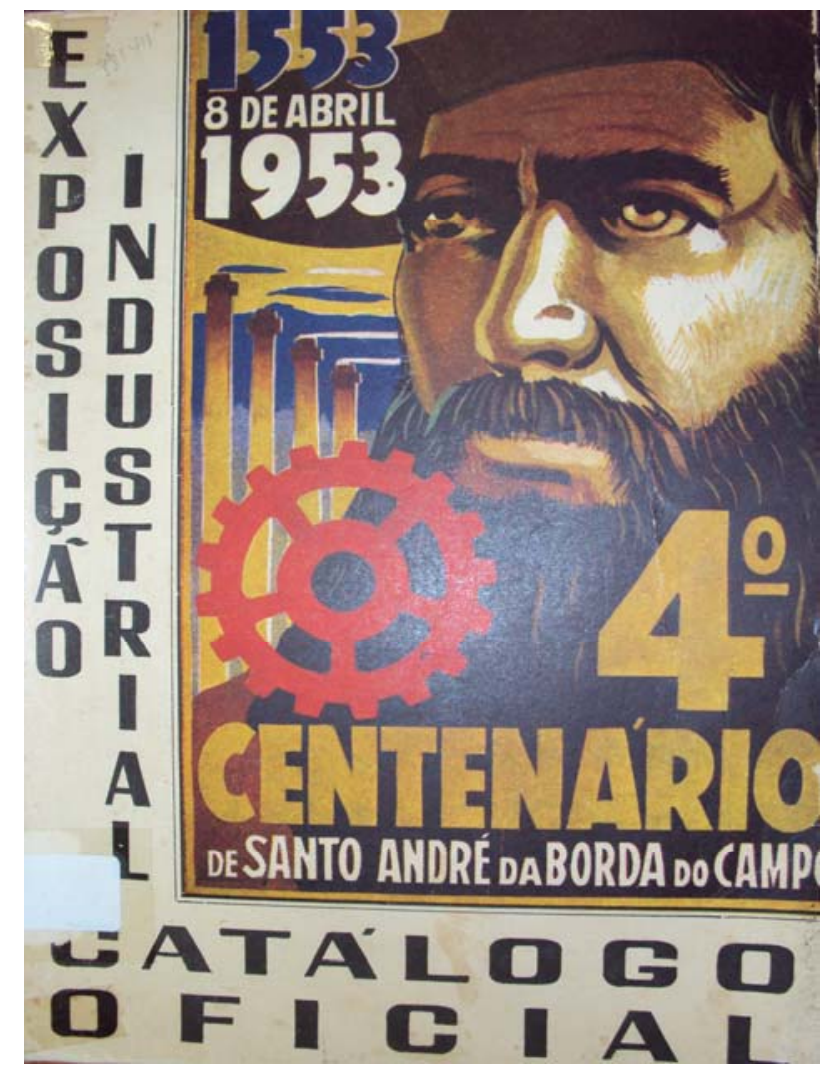

Foto 3 - Capa do Catálogo da exposição Industrial do IV Centenário da fundação de Santo André da Borda do Campo (Arquivo pessoal)

A criação dos símbolos da cidade - hino, brasão (foto 4) e bandeira (foto5) completaram esse processo, a partir do momento em que eles que permitem construir o amor à cidade, conforme foi bem colocado por Catroga ${ }^{43}$.

O hino oficializado pela Lei Municipal n. 541, de 16 de fevereiro de 1950, tem letra de José Amaral Wagner e música de Luiz Carlos da Fonseca e Castro. O

42 Saíram reportagens sobre a fundação de Santo André no Diário de São Paulo, O Repórter, Folha da Manhã, A noite, A Gazeta, O Correio Paulistano, A Estância de Guarujá, O tempo, Folha da Tarde, Cruzeiro do Sul.

43 CATOGRA, op. cit., p. 154. 
brasão $^{44}$ e a bandeira ${ }^{45}$ são criações de Octaviano Gaiarsa e passaram a ser usados a partir de 1972, substituindo os anteriores (ver anexo 4).

A partir da década de 1990, houve procura de novas maneiras de explicar a história do município que, nem sempre, mudaram a versão original de Gaiarsa, conforme veremos nos textos que serão analisados no decorrer do trabalho.

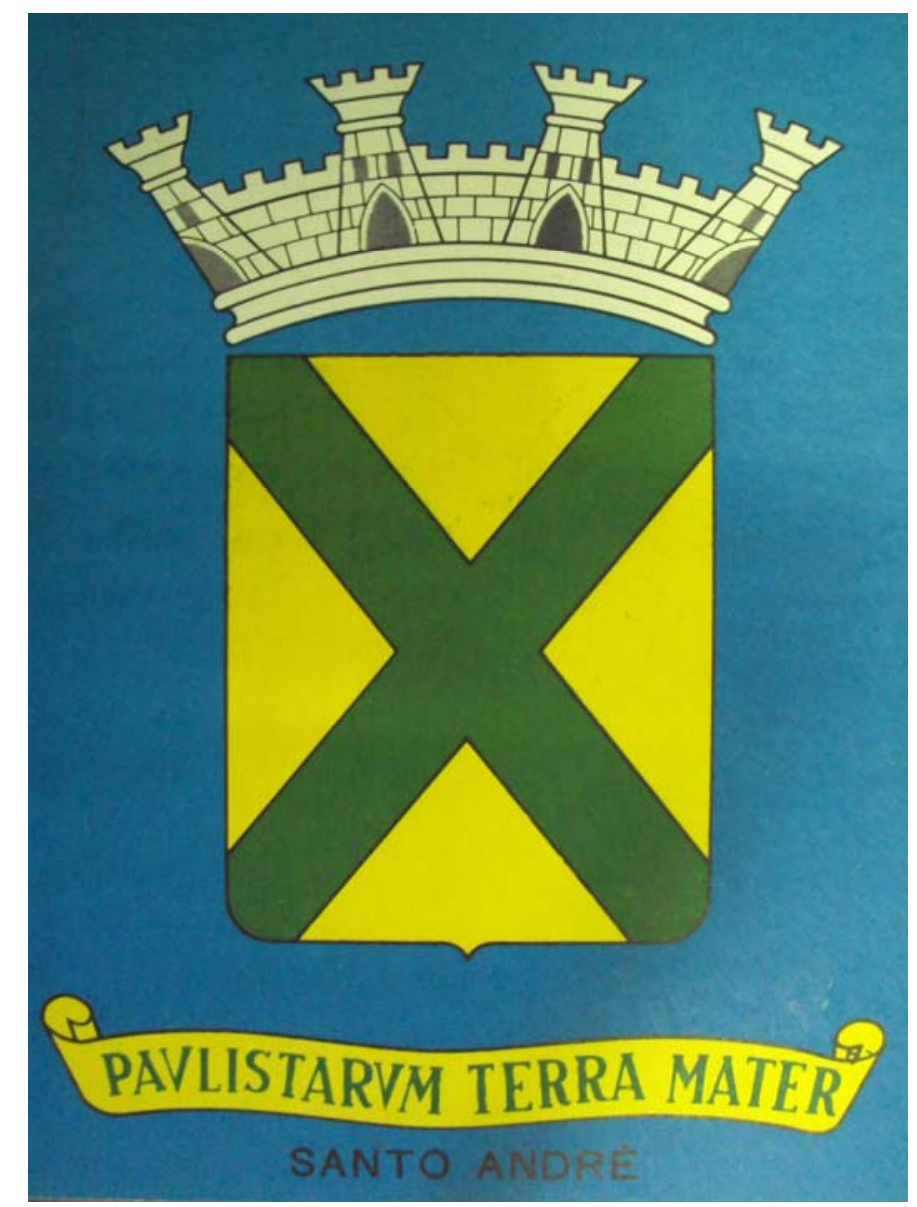

Foto 4 - Brasão de Santo André (Arquivo pessoal)

${ }^{44} \mathrm{O}$ atual brasão de Santo André substituiu o original criado em 1926 por Afonso Taunay e possui as seguintes características: escudo amarelo central, sem divisão interna, pois a cidade não surgiu de outras, ao contrário, foi dividida; Cruz de Santo André verde sobreposta ao escudo; as figuras de carnação (o bandeirante e o índio) que apareciam no brasão anterior foram suprimidas; listel inferior amarelo com a frase: "PAVLISTARVM TERRA MATER" em verde; a palavra PAVLISTARVM segue o mesmo sistema de escrita de 1553, reforçando o elo com a vila quinhentista; supressão da roda dentada do brasão de 1926; coroa mural branca ou amarela com quatro torres, pois as cidades portuguesas obedecem a essa regra. Para compreender o processo que levou à mudança do brasão, consultar: GAIARSA, Octaviano Armando. Brasões e bandeiras do município de Santo André - História. Santo André: Public Grafica e editora Ltda, 2001.

${ }^{45} \mathrm{~A}$ atual bandeira é retangular, dividida ao meio horizontalmente em duas partes, formando dois campos iguais: o superior é amarelo e o inferior verde. No centro, coloca-se o atual brasão da cidade. (Ibid.). 
Veremos a seguir, como ocorre a valorização de Santo André da Borda do Campo e de João Ramalho nessa historiografia, como os autores ligam os dois períodos e, por fim, a explicação que é dada para que a sede da vila mudasse para próximo ao colégio dos jesuítas.

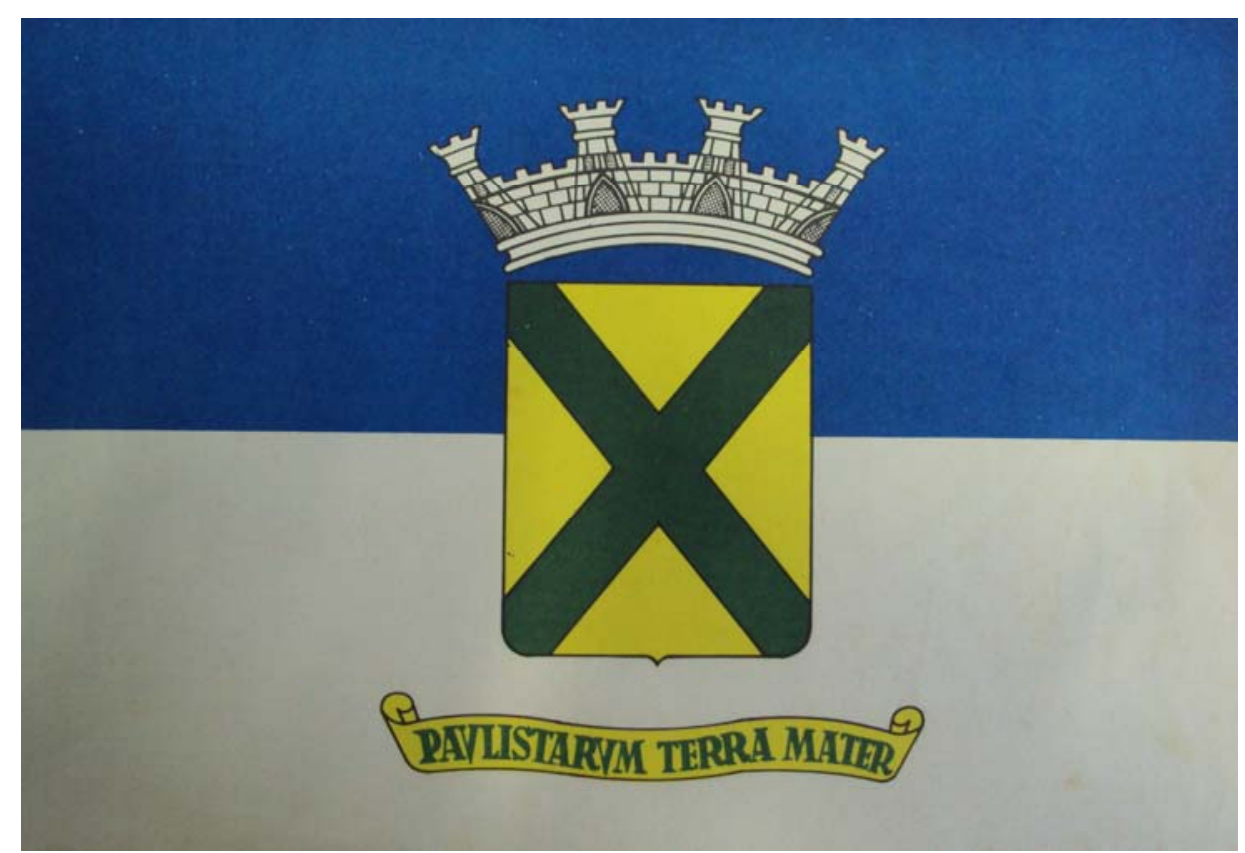

Foto 5 - Bandeira de Santo André (Arquivo pessoal)

\subsection{Valorização de Santo André da Borda do Campo}

$\mathrm{Na}$ construção dos Estados Nacionais, podemos observar que em geral eles são compostos por uma elite política e econômica que, ao tentar estabelecer uma relação de obediência, lealdade e cooperação por parte dos outros grupos sociais, encontra resistência, enfraquecendo, assim, a sua legitimidade.

Partindo dessa problemática, tais elites procuram inventar suas tradições, para estabelecer uma continuidade com um período anterior, que não existiu, idealizando uma idade de ouro, forjando documentos e falsificando a história para provar suas idéias e justificar a sua existência. Tal comportamento foi explicado no estudo de Hobsbawn: 
[...] Não nos devemos deixar enganar por um paradoxo curioso, embora compreensível: as nações modernas, com toda a sua parafernália, geralmente afirmam ser o oposto do novo, ou seja estar enraizadas na mais remota antiguidade, é o oposto do construído, ou seja, ser comunidades humanas, 'naturais' o bastante para não necessitarem de definições que não a defesa dos próprios interesses. Sejam quais forem as continuidades históricas ou não envolvidas no conceito moderno da 'França' e dos 'franceses' - que ninguém procuraria negar - estes mesmos conceitos devem incluir um componente construído ou 'inventado'. E é exatamente porque grande parte dos constituintes subjetivos da 'nação' moderna consiste de tais construções, estando associada a símbolos adequados e, em geral, bastante recentes ou a um discurso elaborado a propósito (tal como o da 'história nacional'), que o fenômeno nacional não pode ser adequadamente investigado sem dar-se a atenção devida à 'invenção das tradições'. ${ }^{46 .}$

Foi em contexto semelhante que a vila quinhentista de Santo André passou a ser engrandecida e o seu "fundador", João Ramalho, mitificado, pois ela passou a ser o embrião, a "célula-mater" da atual cidade, que tem suas raízes em um passado remoto, formulando uma explicação para relacionar essas duas épocas. Não é por acaso que surgem na época as obras de Callado e Gaiarsa, ambas com caráter engrandecedor desse passado.

Callado, mesmo fundamentado no pensamento dominante da historiografia paulista, criou uma obra de ficção, apropriando-se das discussões historiográficas sobre Santo André, principalmente as que se referiam à questão da mudança para próximo à casa dos jesuítas, destacando a visão negativa que os jesuítas tinham sobre a cidade e seus moradores; por outro lado, procurou garantir o pioneirismo da vila no planalto e é esse o ponto principal que também foi recuperado por Gaiarsa que, além de valorizar o pioneirismo, foi o primeiro que procurou relacionar de forma sistemática a vila quinhentista com o município de Santo André, fundado em 1938, através do caráter dos seus moradores, que é o mesmo nas duas épocas, e é responsável pelo progresso da cidade.

Assim, da forma como esses autores apresentaram, foram os moradores da vila quinhentista que deram origem ao Brasil e ao brasileiro. Consequentemente, podemos deduzir que os moradores de Santo André atual também deram a sua contribuição para a formação da pátria. Dessa forma, Santo André era a mais importante cidade do Brasil, inclusive São Paulo, pois a tinha precedido.

${ }^{46}$ HOBSBAWM, Eric; RANGER, Terence (org). op. cit., p. 22-23. 
Sem romper com essa continuidade, o texto sobre a história de Santo André apresentado no site da cidade mais recente, também apresenta a relação entre as duas épocas, a partir do momento em que aparece a imagem (figura 1) elaborada no início do século XIX por Miguel Dutra ${ }^{47}$, do que teriam sido as muralhas da vila quinhentista $^{48}$. O texto especifica a época da produção da imagem, fazendo com que o leitor fique com a impressão que é uma representação real da vila e não uma invenção visual do passado. De certa forma, tenta induzir o leitor a acreditar que aquela vila que realmente existiu, é a origem da atual cidade, através do apelo visual da imagem.

Também no site da Câmara de Santo André ${ }^{49}$ aparece essa relação, porém de forma contraditória. De um lado afirma, logo no início do texto, que Santo André destacou-se desde o século XVI, portanto estabelecendo a continuidade entre as épocas, de outro, informa que a Câmara Municipal só surgiu em 1892

47 Miguel Arcanjo Benício de Assumpção Dutra (1810/1875). Pintor, escultor, ourives, arquiteto, poeta, entalhador, decorador de igrejas, musicista. Autodidata, pertence a uma família que deu origem a várias gerações de artistas. Ao longo de sua carreira, realiza uma série de aquarelas sobre tipos humanos e aspectos da cidade de Itu, além de vistas da cidade de São Paulo e de Piracicaba. As aquarelas, reunidas pelo artista em álbum, pertencem ao acervo do Museu Paulista da Universidade de São Paulo - MP/USP. Sua biografia está disponível em http://www.itaucultural.org.br/aplicExternas/enciclopedia IC/index.cfm?fuseaction=artistas biografia\&cd verbete $=929 \& c d$ idioma $=28555$. Acesso em 1/08/2010. Há várias obras sobre o autor, entre elas: BARDI, Pietro Maria. Miguel Dutra, o poliédrico artista paulista (Itú,1810 - Piracicaba,1875). São Paulo: Museu de Arte de São Paulo Assis Chateaubriand, 1981; MELLO JR, Donato; SOUZA, Jonas Soares de. A contribuição de Miguelzinho Dutra à iconografia paulista do século XIX. Itu (SP), 2000; VELLOSO, Augusto Carlos Ferreira. Os artistas Dutra: oito gerações: presença de mais de dois séculos na arte do Brasil. São Paulo: Imprensa Oficial do Estado de São Paulo: Sociarte 2000; SOUZA, Jonas Soares de. Miguelzinho Dutra: traços e troças da Itu oitocentista, 2004.

${ }^{48}$ Segundo Wanderley dos Santos, "Por volta de 1835, o pintor ituano Miguel Benício da Anunciação Dutra examinou umas ruínas existentes nas vizinhanças de São Bernardo. Moradores próximos diziam que as ruínas eram vestígios do povoado de João Ramalho. Da visita, Miguel Dutra deixou apenas um singelo e impreciso desenho". (SANTOS, Wanderley. Antecedentes históricos do ABC paulista. 1550-1892. Prefeitura do município de São Bernardo do Campo: SECE, 1992).

49 Anexo 2 - História da Câmara de Santo André. Disponível em http://www.cmsandre.sp.gov.br/legislativo/historia.htm AcesSo em 17/05/2010. 


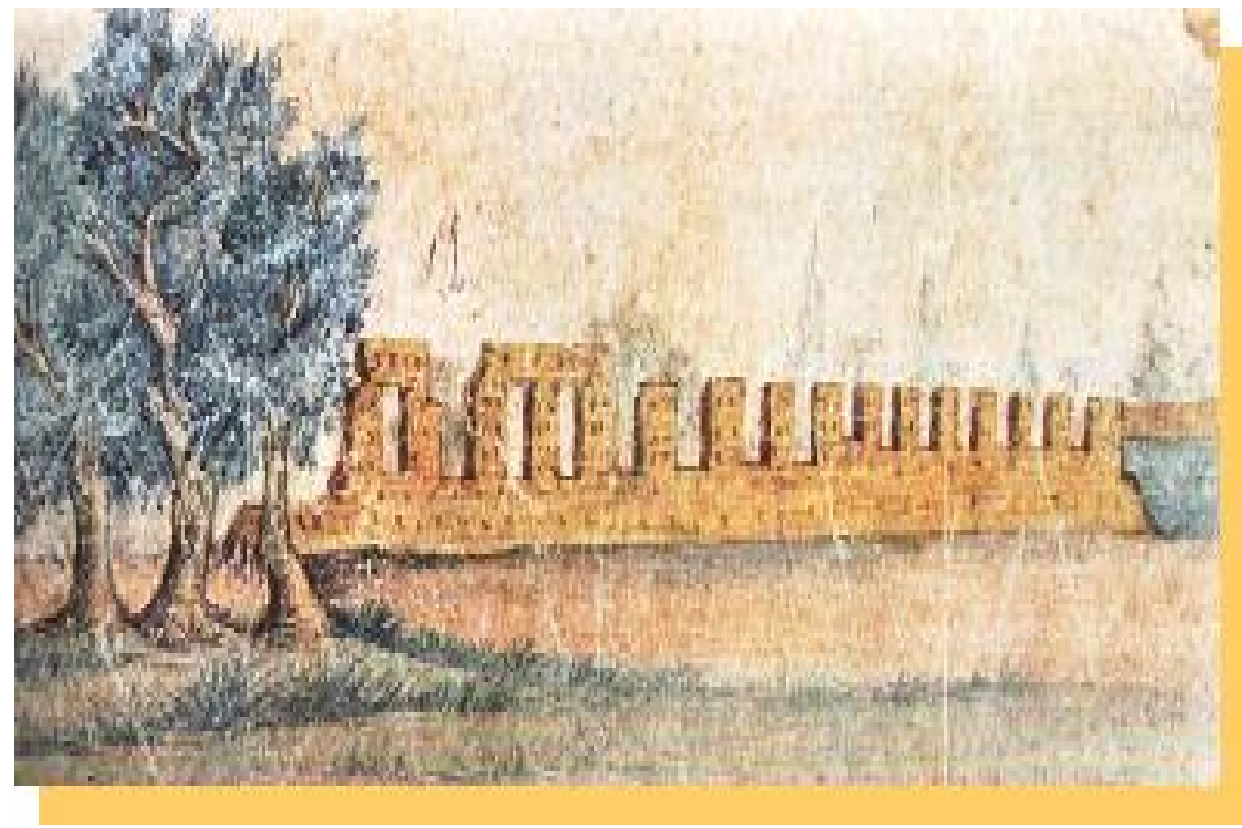

Figura 1 - Ruínas de Santo André da Borda do Campo. Reprodução do livro BARDI, Pietro Maria. Miguel Dutra, o poliédrico artista paulista (Itu 1810 - Piracicaba - 1875). São Paulo: Museu de Arte de São Paulo Assis Chateaubriand, 1981. Aquarela sobre papel.

A imagem de João Ramalho que está nesse site também mostra a relação que é feita entre os dois períodos, valorizando a figura do "fundador" da vila e do "primeiro povoador" do planalto. Porém, desmente novamente a ligação quando afirma que não há relação entre a vila e a cidade, conforme podemos observar a seguir:

A vila de Santo André da Borda do Campo deve ser lembrada por sua importância histórica no planalto e como uma referência do quinhentismo. Nada tem a ver, no entanto, com a segunda cidade, o município de Santo André dos dias atuais. ${ }^{50}$

Nesse texto, a história de Santo André divide-se em duas etapas: a vila quinhentista e o município atual.

Outra contradição, nesse texto, é quanto à referência à mudança da sede do município de São Bernardo para o distrito de Santo André, que se formara em 1910. O texto não deixa claro que foi só depois da mudança que o nome de Santo André voltou a ser usado e a data para o aniversário da cidade passou a ser em 8 de abril (foto 6).

50 Ibid.. 
Para estabelecer a continuidade com a vila quinhentista, os autores procuraram engrandecer a vila e a maneira que encontraram de alcançar tal objetivo foi destacar o pioneirismo de Santo André no planalto e a valorização dos seus moradores, dos quais se originaram os paulistas.

Diversamente dos dados acima citados, o texto do curso de história da cidade do Museu dr. Octaviano Gaiarsa ${ }^{51}$, ministrado em setembro de 2007, é o único que rompe com essas versões, pois, a história da cidade não mais começa no século XVI, mas no ano de 1812, quando foi criada a freguesia de São Bernardo e segue em diante.

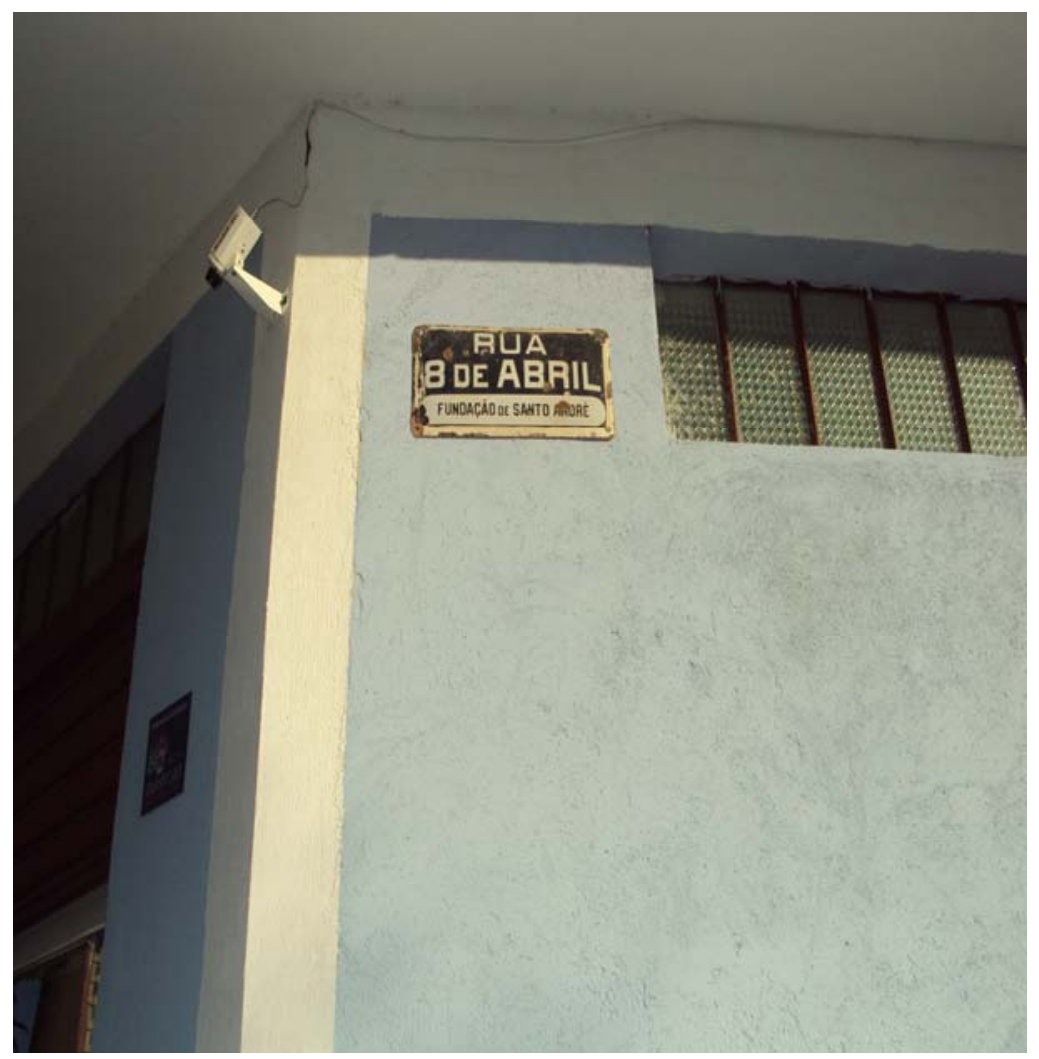

Foto 6 - Nome de rua com a data da fundação da cidade (Arquivo pessoal)

Vale salientar que Callado, ao mesmo tempo em que garantiu o pioneirismo de Santo André no planalto, não procurou esconder que os seus moradores viviam do tráfico indígena, ao contrário das versões posteriores que procuram justificar as suas atitudes não civilizadas. Para ele, "[...] o povoado de Santo André já existia

51 Anexo 3 - Santo André, caminhos percorridos, oferecido pelo Museu Dr. Octaviano Gaiarsa. 
quando foi fundado este colégio aqui, e Santo André vivia principalmente de escravizar índios para vendê-los aos engenhos da costa e aos navios". ${ }^{52}$

No hino da cidade também encontramos que Santo André deu origem ao paulista, com o mestiço do índio e do português, conforme podemos perceber a seguir:

Santo André, livre terra querida, Forja ardente de amor e trabalho, Em teu solo semeias a vida, Em teus lares há pão e agasalho.

Salve, salve, torrão Andreense Gigantesco viveiro industrial! Teu formoso destino pertence Aos que lutam por um ideal!

Três figuras de heróis bandeirantes Isabel $^{53}$, o Cacique e o Reinol Constituíram os troncos gigantes Das famílias paulistas de escol.

Salve, salve, torrão Andreense Gigantesco viveiro industrial! Teu formoso destino pertence Aos que lutam por um ideal!

Se tu foste, no início, um castigo Hoje és benção dos céus sobre nós. Santo André , o teu nome bendigo, Berço e tumba de nossos avós.

Salve, salve, torrão Andreense Gigantesco viveiro industrial! Teu formoso destino pertence Aos que lutam por um ideal!

Eis, pois, a caminho da glória, Santo André do herói quinhentista! Tu serás para sempre na história Marco zero da história Paulista!

Salve, salve, torrão Andreense Gigantesco viveiro industrial! Teu formoso destino pertence Aos que lutam por um ideal!. ${ }^{54}$

CALLADO, op. cit., p. 81.

53 Isabel é o nome cristão de Bartira.

54 O hino de Santo André está disponível em http://letras.terra.com.br/hinos-decidades/942119/. Acesso em 01/08/2010. 
O hino é confirmado com a bandeira e o brasão da cidade, cujo lema é "Terra mãe dos paulistas", conforme podemos verificar nas fotos 4 e 5 (acima).

Gaiarsa, ao contrário de Callado, procurou justificar as atitudes negativas dos moradores, como necessidade do meio, pois, para ele, Santo André era uma terra próspera e os seus moradores corajosos, pois superaram todas as dificuldades, desde os ataques indígenas até a hostilidade do meio. Assim, não era de estranhar que tivessem um aspecto bravio.

Repete nas obras, da mesma forma que no hino e na bandeira, que foram os moradores de Santo André da Borda do Campo que deram origem ao paulista, a partir do momento em que foram para São Paulo e os seus descendentes, os bandeirantes, espalharam-se pelo Brasil, formando, também, o território nacional: "[...] E daí, os descendentes de João Ramalho espalharam-se por todos os quadrantes da pátria Comum (sic), deixando, a perder de vista, a terra humilde e pobre onde viram a luz do dia pela $1^{\text {a }}$ vez". 55

Gaiarsa critica o viajante Ulrico Schmidel ${ }^{56}$, na obra Relatos de La conquista Del rio de La Plata y Paraguay. 1534-1554. ${ }^{57}$ por desvalorizar Santo André, a partir do momento em que afirma que a vila de Santo André era uma aldeia de bárbaros, o que, para o autor, não era possível, pois os seus moradores tinham os costumes de pessoas civilizadas - como o respeito às regras da cidadania e de justiça, bem como as ordens do reino. Ele justifica o caráter dos moradores da vila, argumentando que, devido às dificuldades da região e da época, não poderiam ser "humanos" e muito menos "brandos" - só sobreviviam os mais energéticos e com muita fibra, os fracos eram eliminados pela própria natureza.

Gaiarsa colocou também, que a vitória de São Paulo diante da Confederação dos Tamoios, em 1562, só foi possível com a ajuda dos andreenses que tinham migrado para lá.

55 GAIARSA, Octaviano. A cidade que dormiu três séculos (Santo André da Borda do Campo; seus primórdios e sua evolução histórica: 1553- 1960). Op. Cit., p.33.

56 Ulrico Schmidel nasceu em 1510 e morreu entre 1579 e 1581. Não se sabe com certeza as razões que o trouxeram a América. Nas suas andanças por esse continente, saiu de Assunção com vinte índios carijós em direção a São Vicente em 1553, passando pela região de Piratininga. Em 1554, volta para a Europa e escreve as suas memórias entre 1562 e 1565, cuja impressão se dará em 1567. (FERRETTI, Danilo José Z. A construção da paulistanidade. Identidade, historiografia e política em São Paulo (1856-1930). São Paulo: FFLCH-USP, 2004. Tese de doutorado).

57 SCHMIDEL, Ulrico. Relatos de La conquista Del rio de La Plata y Paraguay. 15341554. Madri: Alianza Editorial, 1986. 
Portanto, para ele, criticar a vila, como feito pelo viajante citado, era uma injustiça, pois, Santo André da Borda do Campo sempre foi uma vila leal ao governo português e forte, graças ao caráter dos seus moradores.

Assim, conforme podemos perceber, a principal preocupação dessa memória é colocar Santo André como "marco zero" da história de São Paulo, valorizando a cidade e os seus moradores, mesmo que, muitas vezes, suas atitudes não possam ser consideradas "civilizadas" e tornando-a a mais importante do que todas as outras.

\subsection{João Ramalho - herói}

Depois de relacionar Santo André atual com a vila quinhentista, através do caráter dos moradores das duas épocas, foi necessário encontrar um herói fundador e esse papel coube a João Ramalho, que passou a ser declarado como o grande patriarca do planalto.

Tal glorificação, entretanto, não começou com Callado, que não se preocupou em esconder o lado negativo da personagem, a partir do momento em que enfatizou não somente suas várias concubinas, entre elas, uma de suas próprias filhas, mas também que a sua relação com os jesuítas era complicada.

Por sua vez, Gaiarsa também explana sobre a discussão do início do século XX, do Instituto Histórico e Geográfico de São Paulo, a respeito do caráter de João Ramalho, chegando a questionar os motivos que o trouxeram ao Brasil, ou seja, se ele seria um degredado, um simples aventureiro ou um náufrago. A questão de ser ou não judeu também é levantada, mas Gaiarsa acaba por negar tal caráter duvidoso do "herói", resgatando Taunay:

Vários cronistas acusam-no de ter sido contrabandista, degredado, traficante de índios ou simplesmente aventureiro ou náufrago de um barco dado a piratarias. Sua ascendência judaica foi aventurada por um autor, após examinar sua assinatura e ter verificado a anteposição de um sinal, o kaf - indicativo de sua progênie. ${ }^{58}$

58 GAIARSA, O. Santo André: Ontem, Hoje e Amanhã. Op. cit., 1991, p. 13. 
Segundo Gaiarsa, João Ramalho nasceu por volta de 1480, chegando ao Brasil entre 1501 e 1510 e foi figura central no Brasil quinhentista, a partir do momento em que se tornou o patriarca dos mamelucos, portanto, dos bandeirantes. A sua vida teria sido a de um verdadeiro herói, que enfrentou todas as dificuldades possíveis para subir ao planalto e unir-se aos indígenas. Foi o herói fundador um andarilho destemido que soube preparar o encontro entre o português e o indígena:

[...] sobe, destemido, as fraldas inclinadas, agarrando-se, em alguns pontos à vegetação rasteira e aos cipós, olhando sempre para os cumes encobertos pela névoa que constantemente os ventos empurram de encontro as cumiadas sem fim. Seu ideal está posto no mistério que o planalto lhe reservava [...]. ${ }^{59}$

Justifica as ações do Ramalho, mesmo as que desrespeitavam as ordens do reino, argumentando que era porque tinha consciência de que era um predestinado e do papel maior que deveria cumprir no planalto.

Também no site da prefeitura de Santo André, encontramos esse papel fundamental de João Ramalho na colonização do Brasil:

\begin{abstract}
Aliada a essa história está a figura de João Ramalho, português que representava, nesse momento, uma porta de entrada para o contato com os índios e para a colonização, pois ele conhecia algumas tribos e conseguia se comunicar com elas. Em contrapartida a sua ajuda, João Ramalho solicitava, desde o início, que o local em que vivia, situado acima da Serra do Mar, fosse transformado em vila [...] Seu pedido foi atendido apenas em 8 de abril de 1553, quando foi criada a vila pelo governador geral Tomé de Souza. Seu nome era Santo André da Borda do Campo. ${ }^{60}$
\end{abstract}

No hino da cidade a glorificação de João Ramalho também está presente, a partir do momento em que ele é visto como o grande herói do período quinhentista e o fundador de Santo André.

A referência ao seu valor e ao seu caráter também pode ser encontrada nos monumentos espalhados pela cidade, como a estátua que se encontra no Paço municipal (foto 7), em nomes de bairros (foto 8) e ruas (foto 9). O próprio time de futebol de Santo André, o E.C. Santo André (fotografia 10), cujo logotipo (figura 2)

59 GAIARSA, O. A cidade que dormiu três séculos (Santo André da Borda do Campo; seus primórdios e sua evolução histórica: 1553- 1960). Op. cit., p. 5.

60 Anexo 1 - História da cidade no site da Prefeitura municipal de Santo André - Disponível em http://www.santoandre.sp.gov.br/bn conteudo.asp?cod=1506 Acesso em 30/03/2009. 
lembra o brasão da cidade, tem por mascote o Ramalhão (figura 3) e a sua sede fica na R. dos Ramalhões. Na letra do seu hino ${ }^{61}$ podemos encontrar a comparação entre o caráter guerreiro de João Ramalho e o dos jogadores, conforme podemos verificar abaixo:

\author{
Santo André do coração \\ Dentre os clubes o maior \\ Uma equipe de valor \\ Pra defender o nosso futebol \\ Tuas cores nos encantam \\ Em cada lance a torcida se levanta \\ Num movimento de bandeiras \\ Em coro te saúda, vibra e canta \\ Salve! Salve! ó grandioso \\ Esporte Clube Santo André \\ Salve! Salve! ó glorioso \\ Santo André da minha fé \\ De João Ramalho a tradição \\ Pois traz no peito o seu brasão \\ És lutador, grande guerreiro, és valente \\ No esporte rei, és campeão, és campeão \\ Tuas cores nos encantam \\ Em cada lance a torcida se levanta \\ Num movimento de bandeiras \\ Em coro te saúda, vibra e canta \\ Salve! Salve! ó grandioso \\ Esporte Clube Santo André \\ Salve! Salve! ó glorioso \\ Santo André da minha fé
}

61 O hino do Esporte Clube Santo André está disponível em http://www.ecsantoandre.com.br/simbolos.html. Acesso em 02/08/2010. 


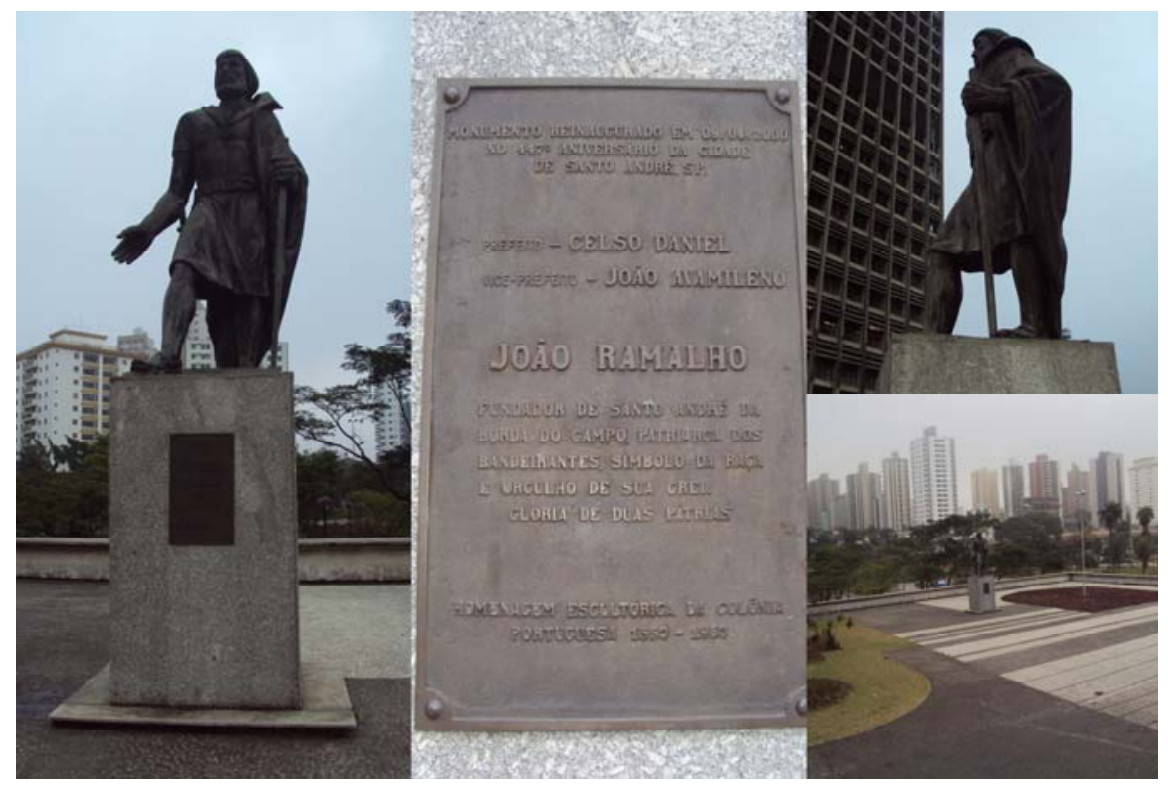

Foto 7 - Montagem de fotos da Estátua de João Ramalho no Paço Municipal de Santo André (Arquivo pessoal)

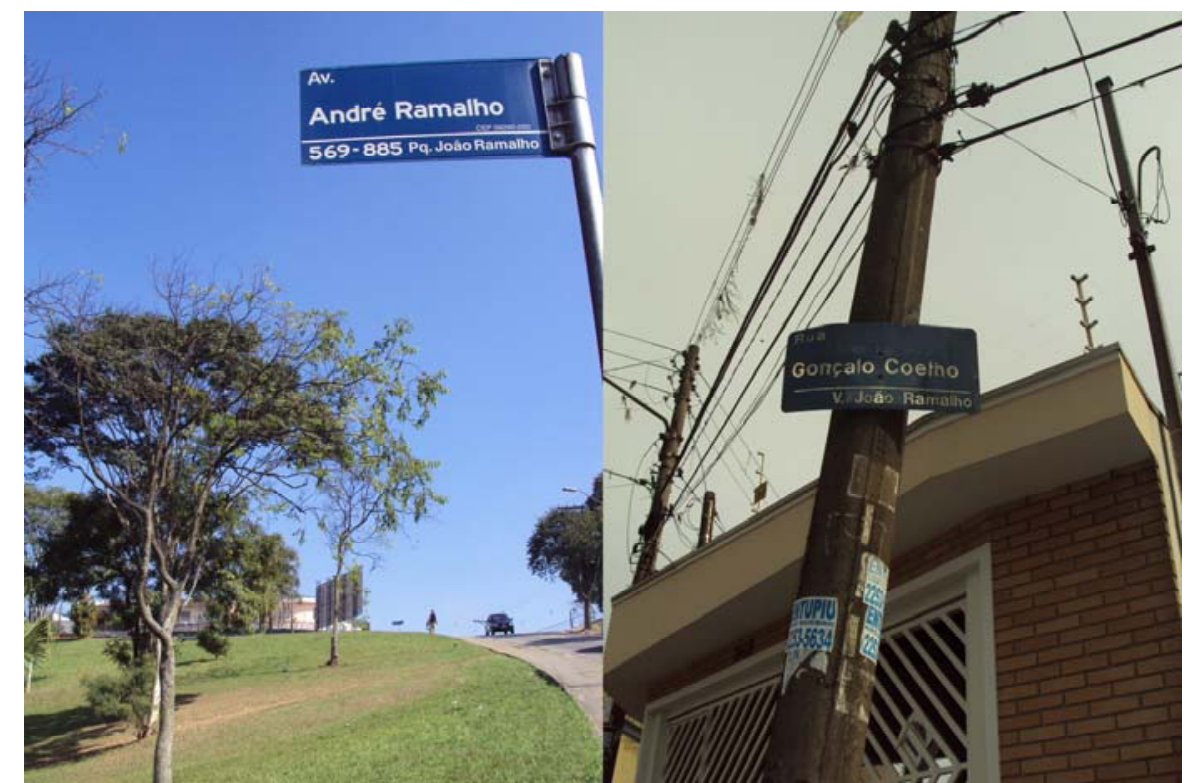

Foto 8 - Montagem de fotos: 1 - Parque João Ramalho; 2 - Vila João Ramalho (Arquivo pessoal) 


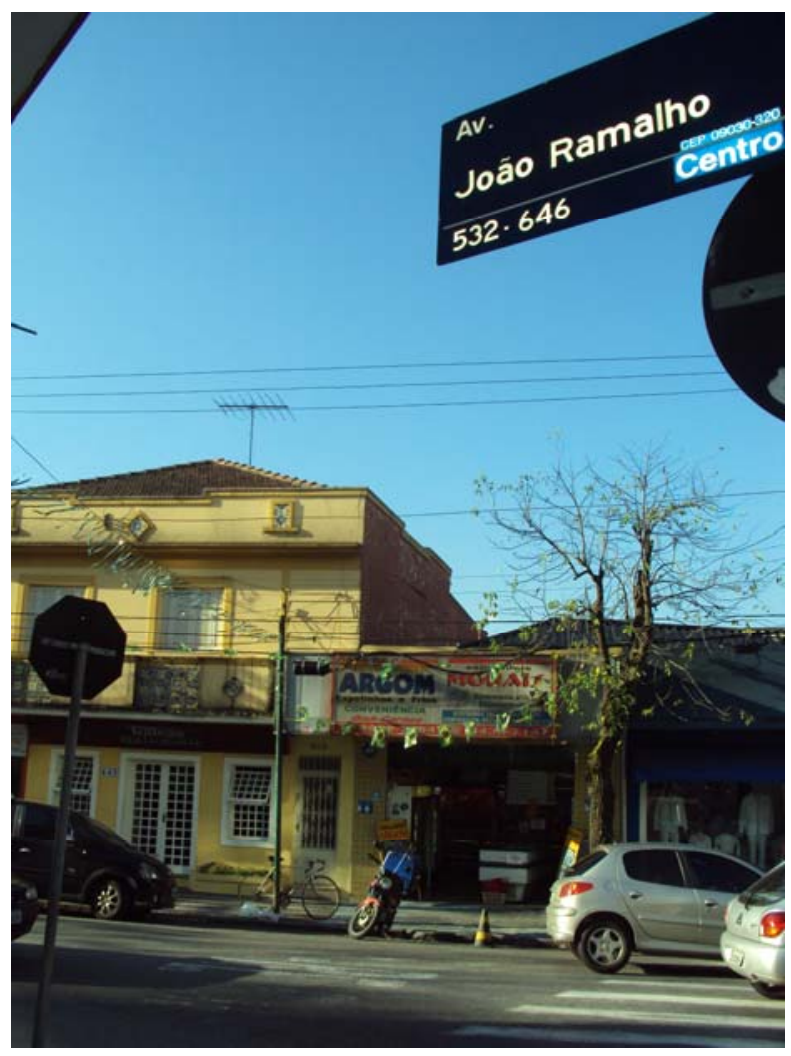

Foto 9 - Av. João Ramalho (Arquivo pessoal)

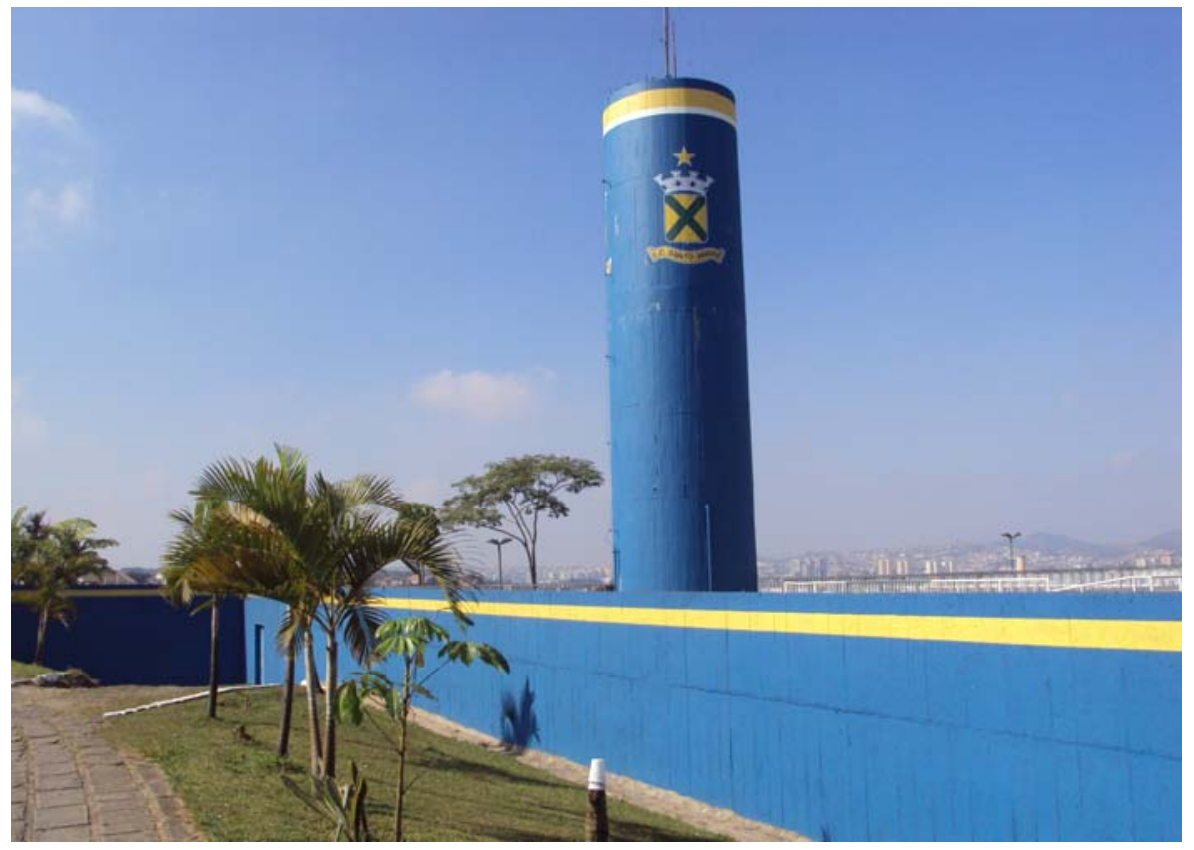

Fotografia 10 - E.C. Santo André (Arquivo pessoal) 


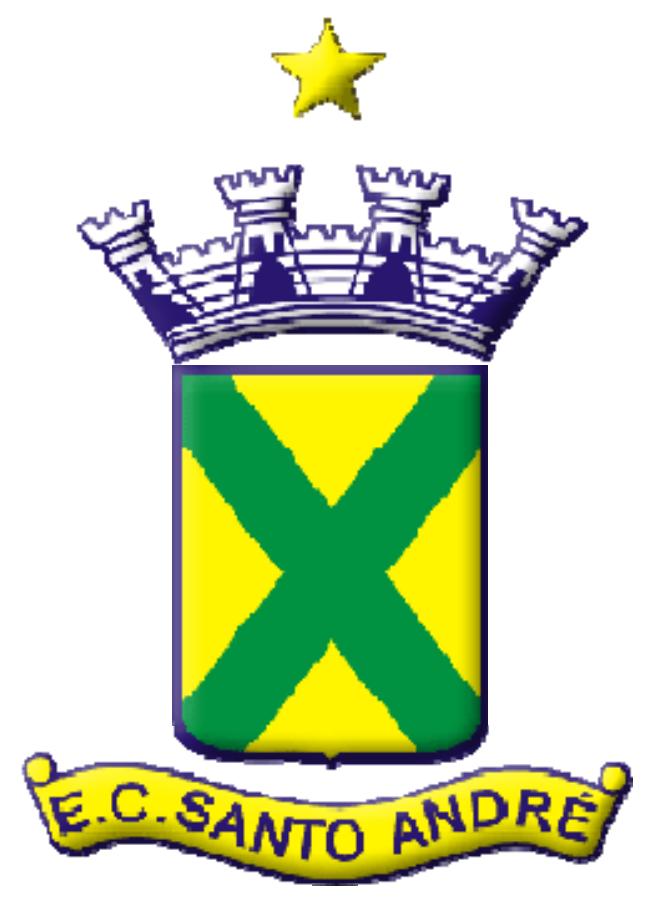

Figura 2 - Logotipo do E.C. Santo André que está disponível em http://www.ecsantoandre.com.br/simbolos.html acesso em 02/08/2010

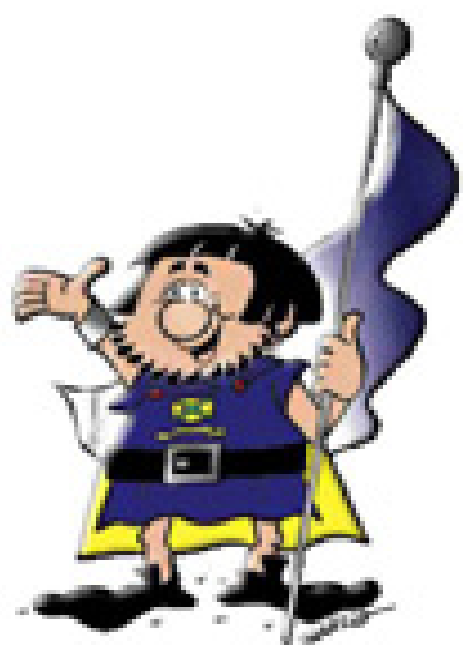

Figura 3- Mascote do E.C. Santo André (Ramalhão) que está disponível em http://www.ecsantoandre.com.br/simbolos.html acesso em 02/08/2010. 
A relação entre as duas épocas não fica apenas na lembrança de João Ramalho, mas também nas pessoas a ele ligadas, como Bartira, Tibiriça e seus filhos como André Ramalho, o Tamarutaca, atualmente nomes de ruas (foto 11), hospitais $^{62}$ (foto 12) e bairros (foto 13) da cidade.

Para saber a localização desses bairros na cidade, observar o mapa de Bairros e distritos de Santo André, no mapa 9.

Assim, conforme podemos observar, João Ramalho só começou a ser cultuado como herói fundador de Santo André, pela cidade, a partir da elaboração do hino e dos livros de Gaiarsa, pois, em Callado ainda observamos a crítica ao seu comportamento.

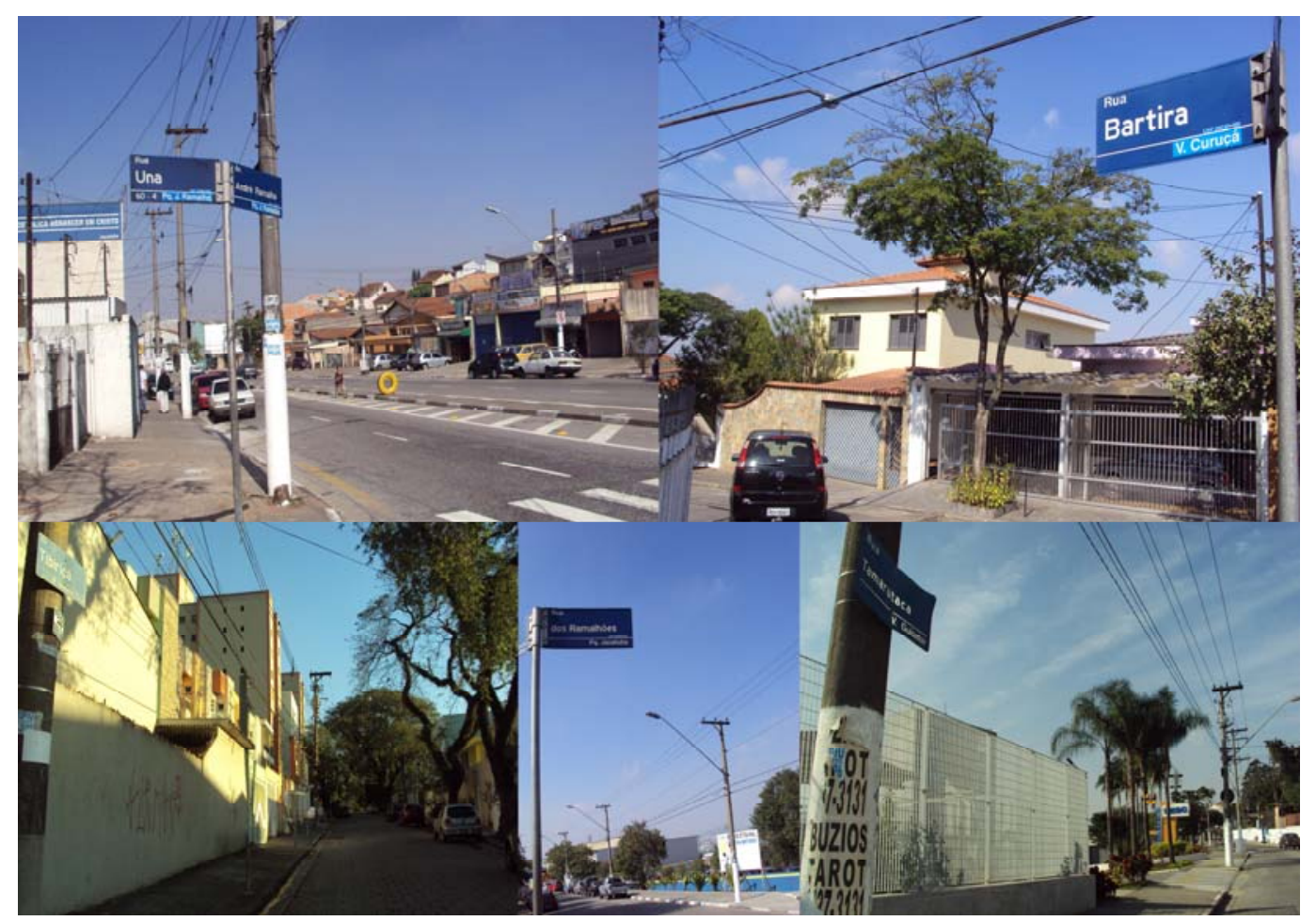

Foto 11 - Montagem de fotos com os nomes de ruas dos personagens quinhentistas ligados a João Ramalho (Arquivo pessoal)

${ }^{62}$ O Hospital e Maternidade Bartira localiza-se na Av. Alfredo Maluf, 430 em Santo André. 


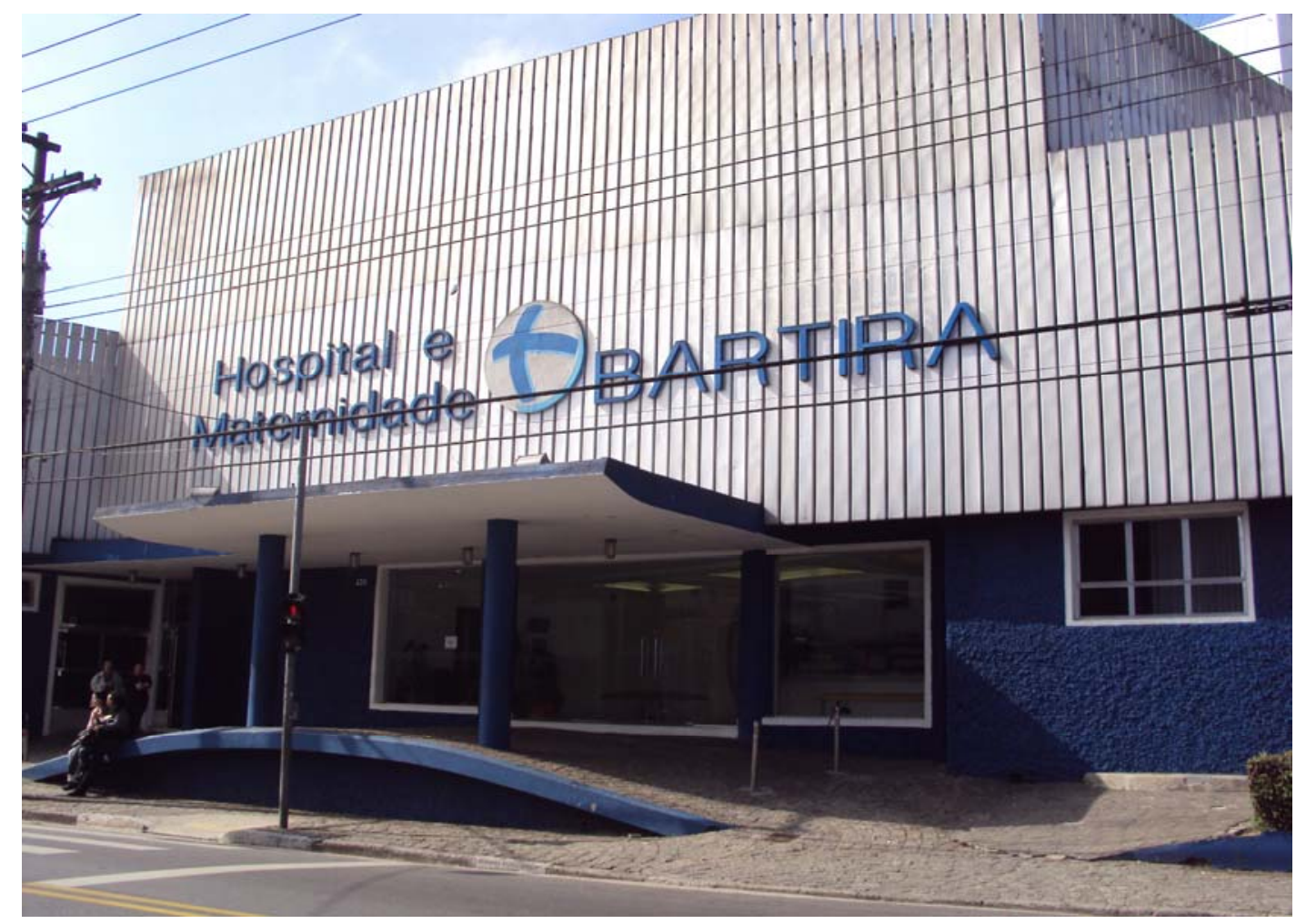

Foto 12 - Hospital Bartira (Arquivo pessoal)

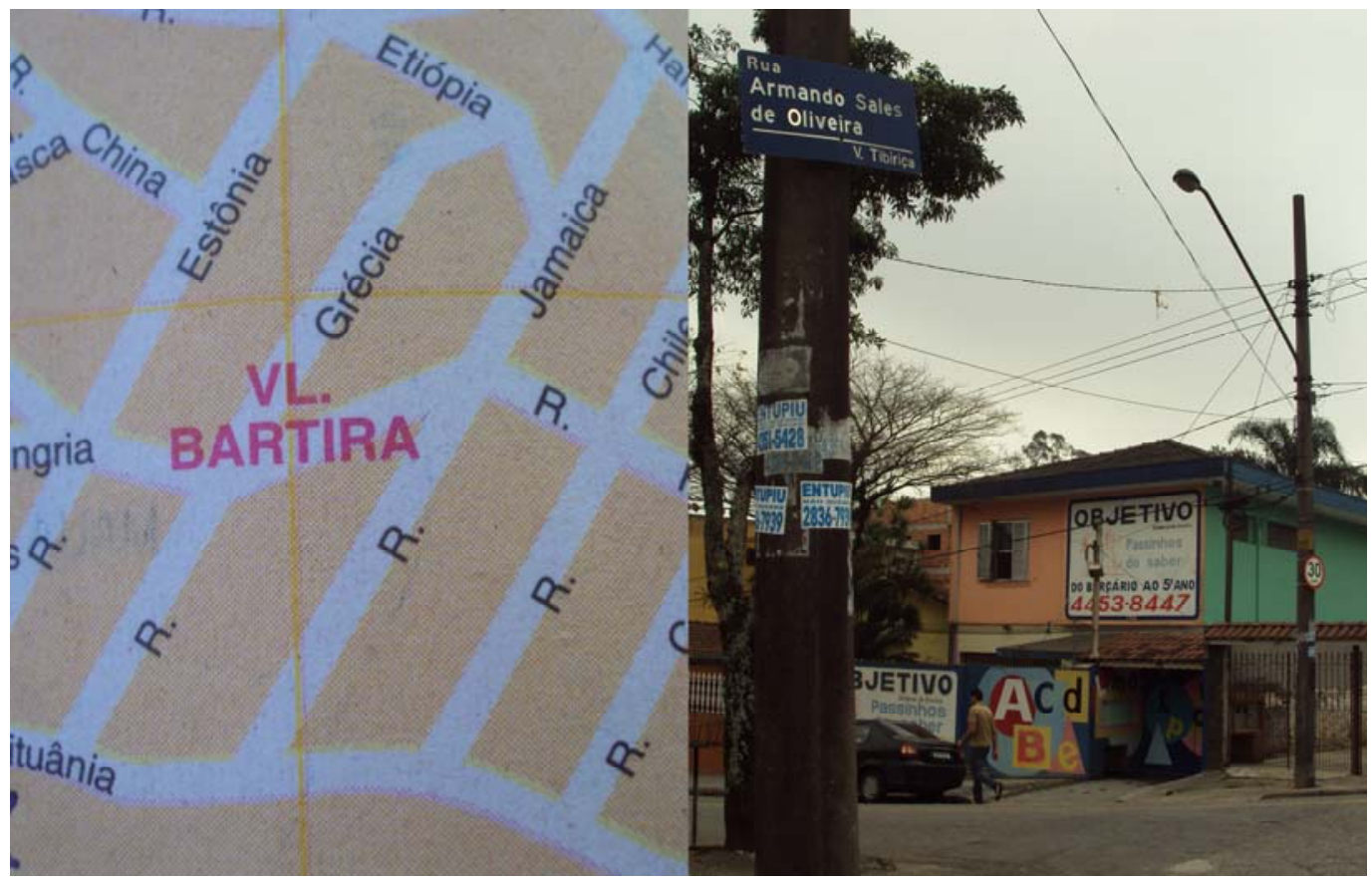

Foto 13 - Montagem de fotos com nomes de bairros dos personagens quinhentistas ligados a João Ramalho (Arquivo pessoal) 


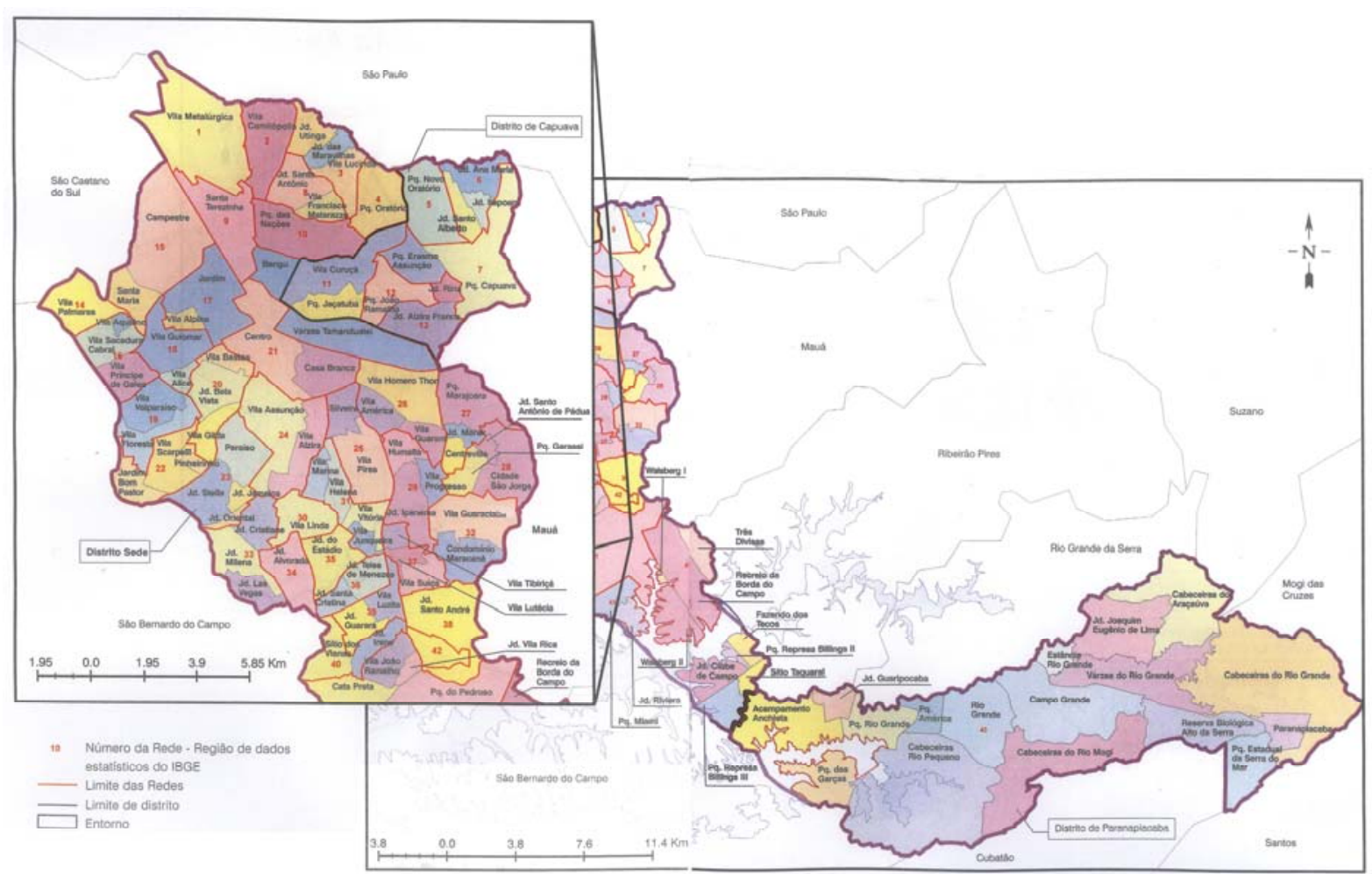

Mapa 9 - Mapas e distritos de Santo André (Sumário de Dados, op.cit., p.368/369)

O culto a Memória de João Ramalho continua presente, conforme podemos observar no poema Vouzela - a Terra, os Homens, a Alma, de Maria da Glória Girão, Maria Teresa Tavares e Francisco Cunha publicado no Diário do Grande ABC de 29/08/2004: ${ }^{63}$

Uma estória vou contar,

A quem possa interessar,

Um pedido da Memória,

Que deseja grande glória,

Referindo-se a Vouzela,

Lugar que sempre se anela;

A vila de João Ramalho

Que em Santo André mostrou malho.

$[\ldots]$

Os costumes vão marcando,

Às novas leis se adaptando,

Nomes que deixam vitória,

Alguns poucos sem ter glórias,

Vai passando toda gente:

Melo, Almeida e contingente,

Inclusive os Ramalho

Sem da árvore ter galho.

$[\ldots]$

63 Artigo disponível na hemeroteca do Museu Dr. Octaviano Gaiarsa, pastas 101 a 104. 
João Ramalho foi servil, Partindo para o Brasil, Logo galgando o planalto,

Santo André funda num salto, Hoje cidade gigante, Nascida de um triunfante, De Vouzela grande filho, Valorizando seu brilho.

João Ramalho Maldonado, Por lá bem considerado, Saiu daqui em 1508,

Talvez jovem bem afoito, A ensejar aventura, Tem vida que muito dura, Pra Vouzela jamais volta, Sua família não solta

Tal qual Santo André, Vouzela, Foi perdendo território, hoje tem um ABC.

A primeira, municípios com seus bairros progressistas, A outra, grandes Concelhos Com distintas freguesias Ambas cidades históricas [...] Além de tudo que mostram Para lembrar seus heróis, Desejamos dar destaque À imprensa que convém De Santo André - um "Diário" De Vouzela - "Notícias", Os dois para cobrir fatos Das regiões de dois rios

E assim vou terminar, Esta estória que asseguro, Tem mil lances de verdade Também brejeiras figuras, pois a Alma de Vouzela, Cativou-me para sempre

E se amo Santo André, a ela agora também.

De João Ramalho bem pouco, Apenas nome de rua, Não conhecem o seu valor Pelas bandas do Brasil, Talvez por sair bem cedo, Só recebem as notícias Aos Vouzelenses, abraços De tudo que vi, saudades, 
O poeta andreense Zhô Bertholini no seu poema Poética Urbana ${ }^{64}$, também se refere a João Ramalho como um conquistador e pai dos bandeirantes:

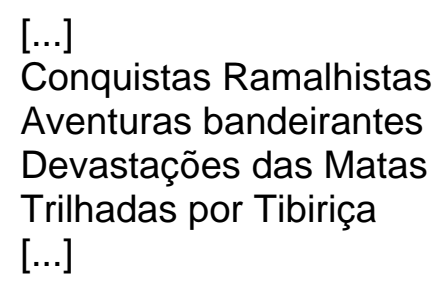

No Poema Fundação de São Paulo ${ }^{65}$, de Judas Isgorogota, encontramos os temas presentes nas discussões historiográficas sobre João Ramalho:

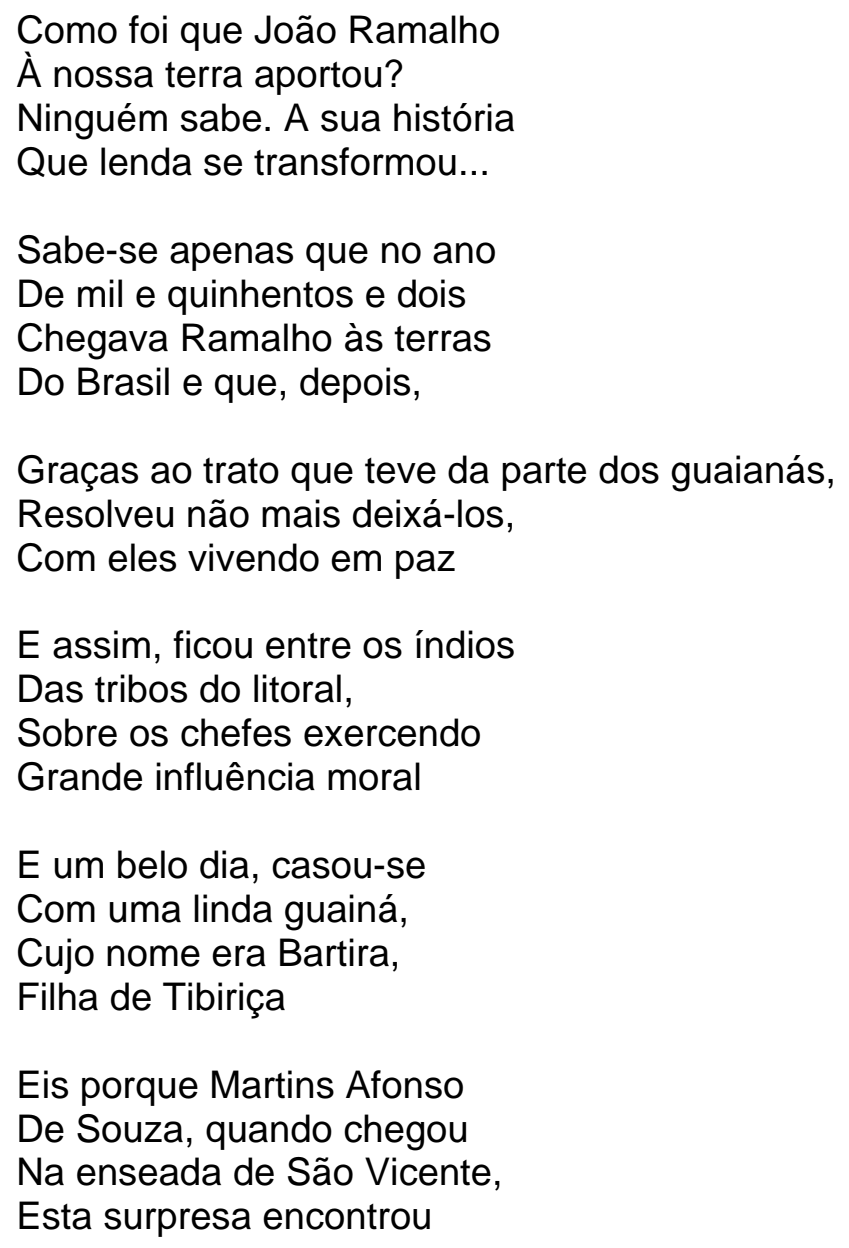

${ }^{64}$ O poema foi publicado no livro de Zhô Bertholini, Poética Urbana, Coleção Poéticas, Santo André: Editora Alfarrabio 1996. (NEVES, João Alves das. Revista das Comunidades de Língua Portuguesa - João Ramalho. N. 19. São Paulo, 2003, p. 116).

65 Esse poema foi publicado no livro de poesias infantis: ISGOROGOTA, Judas. Sapatinhos de prata. São Paulo: Edição Saraiva, 1954, publicado em homenagem à cidade de São Paulo no IV centenário da fundação sua fundação. (NEVES, op. cit., p. 115/116). 
Entre aquela gente inculta

Que andava em plena nudez,

Havia quem Ihe falasse

No idioma português.

\subsection{Vitória de São Paulo}

A maioria dos historiadores que estudamos explica que a mudança da sede da vila de Santo André para junto à casa dos jesuítas foi o resultado de uma disputa entre João Ramalho e os moradores de Santo André, de um lado e, do outro, os jesuítas.

Num primeiro momento, podemos perceber essa oposição de maneira explícita, na peça A cidade assassinada, a partir do momento em que seu autor argumenta que a origem dessa rivalidade estava no tráfico e na escravidão indígena feita pelos portugueses:

Em Santo André os homens escravizam os índios, quando os índios têm uma alma que pertence a Deus. Em Santo André não se castigam os crimes contra a moral. Em Santo André os homens tem quantas concubinas querem e ainda pecam com as próprias filhas. ${ }^{66}$

E como resultado dessa rivalidade, os jesuítas influenciaram o Governador Geral, Mem de Sá, pressionando-o para que a sede da vila mudasse para próximo ao local em que moravam, argumentando que era para se ter mais segurança, diante do perigo dos índios tamoios, que estavam formando uma confederação com o apoio francês. Para ele, João Ramalho havia continuado com as mesmas funções que antes:

Santo André não é uma cidade defensável diante de um ataque indígena maciço, na borda como está do campo, sem nenhuma visibilidade sobre suas próprias cercanias, enquanto São Paulo, de atalaia em suas alturas, poderia defender-se indefinidamente $[\ldots]^{67}$

66 CALLADO, op. cit., p. 21.

67 Ibid., p. 50. 
Callado argumenta que Santo André era muito precária e não conseguia defender-se dos tamoios, mesmo com a tentativa de tentar fortificá-la. Porém, segundo o autor, esse não era um problema para a casa dos jesuítas em São Paulo, melhor localizada, tanto que João Ramalho e os andreenses conseguiram vencer os tamoios, partindo de São Paulo.

Como as atas da vila de Santo André da Borda do Campo desapareceram entre 1558 e 1560, o autor conclui que a cidade "desapareceu" nesse período. As atas seguintes que existem datam de 1562, quando a vila já estava transferida para São Paulo.

Gaiarsa repete essa argumentação, quando explana que o seu pelourinho foi "arrancado" para servir à sua rival e os seus habitantes foram para São Paulo. Podemos constatar isso no texto abaixo, no qual o autor, humanizando a cidade, diz como essa mudança a "entristeceu":

Foi assim Santo André da Borda do Campo. Aniquilada e abatida, palpitou tristemente apenas nos corações daqueles que, abandonando-a por ordem de Mem de Sá, foram acolhidos na vila de São Paulo, ajudando-a na sua construção e desenvolvimento, na sua defesa e na sua expansão incontida e ilimitada [...]. ${ }^{68}$

A justificativa que a causa da mudança havia sido a falta de condições de defesa também está presente no site da prefeitura de Santo André. Porém, acrescenta a dificuldade de subsistência. Assim, esses dois fatores teriam levado os jesuítas a pedirem a transferência da sede da vila:

Dificuldades de subsistência e de proteção fizeram com que a vila de Santo André fosse transferida para São Paulo de Piratininga em 1560, através da proposta do Padre Manoel da Nóbrega ao Governador Geral Mem de Sá. ${ }^{69}$

Por sua vez, o site da Câmara dos Vereadores apenas cita a mudança, sem colocar os motivos, acrescentando que essa mudança encerra a primeira etapa da história da cidade e a segunda começará apenas no século XIX.

Nesse texto, o eixo que une os dois períodos são as atas da Câmara. Dessa forma, há um primeiro período entre 1553 e 1560 - quando a Câmara e suas atas

${ }^{68}$ GAIARSA, O. A cidade que dormiu três séculos (Santo André da Borda do Campo; seus primórdios e sua evolução histórica: 1553 - 1960, op. cit., p. 33.

69 Anexo 1, op. cit.. 
foram transferidas para São Paulo - e outro, que começa no século XVIII com a fixação da sede dos beneditinos na região da antiga vila e o início do povoamento. Porém, como a autonomia do município de São Bernardo só ocorre em 1890, é a partir dessa data que voltamos a encontrar atas na região, agora sob a denominação de São Bernardo e não mais Santo André.

Assim, podemos concluir que há duas formas de colocar a mudança para as proximidades da casa dos jesuítas. A primeira, na versão de Antonio Callado, não se preocupa em esconder o caráter dos moradores e a oposição aos padres jesuítas. Esse autor tem a mesma visão negativa que alguns autores da história de São Paulo sobre Santo André. E assim, ele coloca que a mudança para São Paulo foi o "assassinato" de Santo André.

A segunda versão é a de Gaiarsa, para quem João Ramalho teria sido o primeiro herói e Santo André, a pioneira do planalto. Nesse contexto, a mudança de sede de vila aparece como sendo a morte da vila, da mesma forma que para Callado, porém, sem realçar a oposição entre os jesuítas e os seus moradores, destacando que a vila teria sobrevivido no espírito dos seus moradores. Espírito esse que passou para os seus descendentes - os moradores de São Paulo, os habitantes do planalto e do Brasil.

\subsection{Renascimento da "Fênix"}

Partindo do pressuposto que a cidade de Santo André é a continuidade da vila quinhentista, a forma que os autores encontraram para preencher o vazio temporal entre 1560 e o início do século XIX, variou entre o discurso da "hibernação" e o da "estagnação".

Fazendo uso da humanização da cidade, a forma que Gaiarsa encontra para relacionar as duas épocas foi a "hibernação" da vila. Segundo o autor, depois de tanto trabalho - ter fundado a família bandeirante e salvado o planalto dos tamoios- a cidade merecia um descanso, que teria durado trezentos anos: 
permaneceu numa longa hibernação. Numa longa e merecida pausa após uma trepidante e exaustiva tarefa de criar a família bandeirante e mameluca, dobrara linha das Tordesilhas, descobrira as minas de ouro e abrira caminhos e veredas em todas as direções. ${ }^{70}$

Assim, Gaiarsa enobrece a vila e encontra uma gloriosa justificativa para unir as duas épocas: "Cumprida a tarefa imensa, a cidade que dera tão ilustres e valentes filhos, a cidade que fora o ninho de uma grande civilização, tinha direito a uma trégua". 71

Da mesma forma que durante o sono há silêncio, reinou o silêncio nas ruínas da antiga e extinta sede da vila, durante esses trezentos anos:

Após sua destruição pelos tamoios, Santo André adormeceu e assim permaneceu numa longa e profunda hibernação; numa pausa merecida após exaustiva tarefa de criar a família bandeirante e mameluca que dobraria a linha das Tordesilhas, descobrindo as minas de ouro e esmeraldas, percorrendo por todas as veredas virgens do planalto. Cumprida a tarefa, tinha direito a uma trégua após uma caminhada trabalhosa, agitada, buscando os galardões colhidos pelos seus heróis no princípio da existência da pátria brasileira. Aniquilada e abandonada, palpitou apenas nos corações daqueles que foram recolhidos na vila de São Paulo, ajudando-a na defesa de sua expansão muito além dos limites sonhados pelos seus fundadores. ${ }^{72}$

O texto do site da prefeitura aproveita-se dessa idéia e para preencher o espaço de 300 anos entre as duas épocas, substitui a idéia de hibernação pela de estagnação. A cidade não é mais comparada a um ser vivo, mas o sentido da "vila que deixa de existir" é o mesmo, bem como a sua relação com o município atual: "A partir de então, Santo André deixou de existir enquanto unidade administrativa, passando a ser um bairro de São Paulo. A região passou por um período de estagnação [...]". 73

Por sua vez, no site da Câmara, há relação entre as duas épocas através da Fazenda dos Beneditinos que se localizava nos domínios da antiga vila, da qual a cidade atual surgiu.

70 GAIARSA, O. A cidade que dormiu três séculos (Santo André da Borda do Campo; seus primórdios e sua evolução histórica: 1553- 1960), op. cit., p. 33.

${ }^{71}$ GAIARSA, O. A cidade que dormiu três séculos (Santo André da Borda do Campo; seus primórdios e sua evolução histórica: 1553- 1960), op. cit., p. 33.

72 GAIARSA, O. Santo André: Ontem, Hoje e Amanhã, op. cit., p. 25.

73 Anexo 1, op. cit.. 
Depois dessa longa estagnação ou hibernação, conforme o caso, a cidade renasce ou ressurge e a forma que cada autor encontrou para justificar esse processo decorre de sua visão de história.

Para Gaiarsa, a cidade possuía um destino pré-determinado e, como tal, não poderia deixar de voltar a existir e ser gloriosa como fora outrora e a solução que encontra foi a de comparar Santo André a uma fênix:

O aldeiamento tem vida efêmera; menos de 7 anos, pois segundo consta das atas da Câmara, a cidade foi abandonada em 1560 e seus alicerces foram destruídos pelos índios. Nunca mais foram localizadas as suas ruínas que, na verdade, nasceu prematuramente. Num mundo no qual o destino não lhe proporcionaria oportunidade para tornar-se adulta. Entrou em hibernação, para retornar à vida três séculos depois da morte aparente, ressurgindo das cinzas qual Fênix mitológica. $^{74}$

A pré-destinação da cidade, além de ter influenciado em seu renascimento no século XIX, ajudou em seu desenvolvimento e em sua prosperidade.

A fênix nasce, desenvolve-se e morre, fechando um ciclo e começando outro. Com a cidade ocorre o mesmo, mesmo que tenha demorado três séculos. O vôo da cidade é para o infinito da mesma forma que o crescimento da cidade também aponta nessa direção. Para Gaiarsa, "Qual fênix ressurgida das cinzas, desperta lentamente, estendendo as asas e iniciando um vôo com os olhos voltados para o infinito". ${ }^{75}$

Porém, a diferença entre as duas épocas é que a atual Santo André não irá mais morrer, será eterna e uma das maiores e mais importantes cidades do Brasil.

A partir dessa parte, Gaiarsa é mais objetivo, ao afirmar que o que despertou a cidade da lentidão e do retrocesso foi a intervenção de dois fatores, que, para ele, vieram com a ajuda "divina" - a construção da estrada de ferro São Paulo Railway, fundada em 1867, e a instalação das usinas de eletricidade da Light \& Power na baixada de Cubatão.

Assim, a atual cidade nasce do povoado que surge na parada provisória da estação São Bernardo. Porém, é a imigração que marca o grande desenvolvimento demográfico e econômico da região. Em 1877, os imigrantes compram terras dos beneditinos e dividem-se em dois núcleos coloniais, São Caetano e Jurubatuba. O

${ }^{74}$ GAIARSA, O. Santo André: Ontem, Hoje e Amanhã, op. cit., p. 7.

75 Ibid., p. 25. 
seu trabalho firme é o responsável pelo renascimento e desenvolvimento da cidade atual e permite construir o futuro. Dessa forma, Gaiarsa consegue valorizar o imigrante, que é o responsável pela formação étnica e pelo progresso da região:

Divididos entre as colônias de São Bernardo e São Caetano entregaram-se ao trabalho rude do desmatamento e construção dos primeiros casebres, levantando os alicerces dos atuais municípios. Unidos, dedicados ao trabalho, firmes na faina de edificar para o futuro, para os filhos, netos e bisnetos que, muitos anos depois $[\ldots]^{76}$

Percebemos no autor uma grande preocupação em mostrar que Santo André só conseguiu desenvolver-se devido ao trabalho persistente, ordeiro, ativo e duro dos imigrantes. Essa valorização do imigrante não deixa de ser pertinente, pois Gaiarsa era neto de imigrantes italianos. O autor encontra uma maneira de encaixálos na história da cidade de um modo glorioso: "Mas o destino havia traçado as suas metas. Apenas aguardava o momento propício para efetivar seus desígnios, marcando o desenvolvimento de fatores decisivos para um futuro feliz". ${ }^{77}$

No hino de Santo André também encontramos a mesma idéia a partir do momento em que Amaral Wagner valorizou o crescimento de Santo André, a maior de todas as cidades e que havia dado origem ao paulista.

Mesmo os jornais da época relacionam a vila quinhentista com a atual cidade industrial, é o que podemos observar na figura 4, publicada no jornal A Gazeta, de 9 de julho de $1557 .^{78}$

76 GAIARSA, O. A cidade que dormiu três séculos (Santo André da Borda do Campo; seus primórdios e sua evolução histórica: 1553-1960), op. cit., p. 48.

77 GAIARSA, O. Santo André: Ontem, Hoje e Amanhã, op. cit., p. 27.

78 Imagem extraída da Hemeroteca do Museu dr. Octaviano Gaiarda, op. cit. 


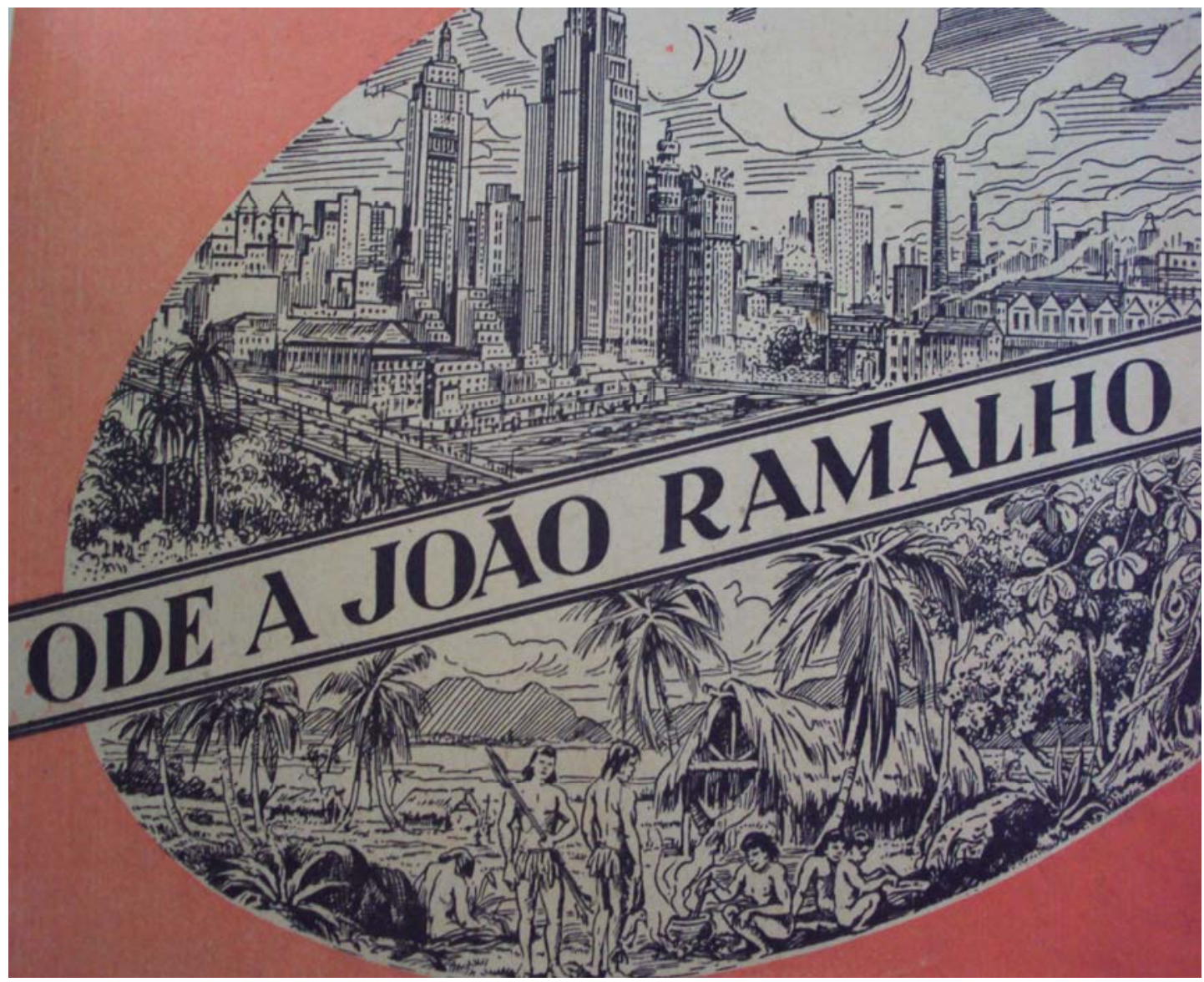

Figura 4 - Jornal A Gazeta de 9 de julho de 1557 - Hemeroteca do Museu Dr.

Octaviano Gaiarsa

O texto no site da Prefeitura ${ }^{79}$ também repete a visão determinista de história de Gaiarsa, pois apresenta o crescimento acelerado da cidade a partir do século XIX, afirmando que o desenvolvimento de Santo André é decorrente da criação da ferrovia, do café, das indústrias e da imigração, porém sem o ufanismo que encontramos em Gaiarsa.

Destacamos que este texto é contraditório, pois mesmo relacionando as duas épocas, conforme anteriormente citado, afirma que a origem do atual município está atrelada ao de São Bernardo, nascendo sob a bandeira da indústria.

A partir daí, relaciona todas as indústrias criadas no final do século XIX e início do século $X X$ e insere as fotos de algumas delas, para provar que existiram. Através do apelo visual, procura cristalizar a visão de que Santo André é uma cidade industrial.

79 Anexo 1, op. cit.. 
No texto, a transferência da sede do município de São Bernardo para o distrito de Santo André decorre da importância dessa região. Mas, não há referência à mudança de nome de São Bernardo para Santo André.

Há, também, uma preocupação em relacionar a história local à nacional, apontando para as mudanças que ocorreram no país na década de 1930, com a criação da Consolidação das Leis do Trabalho (CLT), do salário mínimo, da Justiça do Trabalho e do sindicato corporativista, bem como o crescimento das idéias comunistas.

Ao lado da industrialização, o texto realça as greves e as conquistas operárias, como a jornada de 48 horas semanais e a criação da Liga Operária de São Bernardo, de inspiração anarquista, procurando chegar aos dias atuais. Termina por afirmar que houve uma pausa nesse crescimento a partir da década de 1970 início da desaceleração da economia, o que altera o perfil da cidade, passando de um parque industrial para uma região de serviços e de comércio, a partir da década de 1990.

O curso de história da cidade de Santo André oferecido pelo Museu Dr. Octaviano Gaiarsa também valoriza o desenvolvimento industrial da região, que é acompanhado pelo desenvolvimento do movimento operário, como o subtítulo de "novas relações"80.

Porém, mesmo com a preocupação em colocar as novas temáticas da história e os novos sujeitos, destacando o papel do movimento operário, o texto não conseguiu fugir do discurso que Santo André é a "cidade que mais cresce" de Gaiarsa. Isso pode ser constatado a partir do momento em que podemos deduzir que o seu movimento operário é o mais importante do país e é o que mais se desenvolveu, acompanhando o crescimento das indústrias.

No curso do Museu há destaque para os primeiros moradores, que teriam sido os migrantes, que se deslocaram para a região nas décadas de 1940 e 1950, com o subtítulo de "novos personagens" da história local e não mais os imigrantes como no texto da Prefeitura.

A década de 1950 é considerada a "década da transformação" ${ }^{81}$, pois nesse período há o crescimento acentuado das indústrias e da população. A partir de 1978, ocorre uma atuação significativa dos sindicatos da região na história nacional,

80 Anexo 3, op.cit..
81 Ibid.. 
principalmente do sindicato dos metalúrgicos: a região passa a exercer papel de liderança nacional.

Conclui o texto com a afirmação que houve mudança na estrutura produtiva da região nas últimas décadas, passando de uma região industrial para de serviços, da mesma forma que o texto do site da Prefeitura coloca.

Assim podemos concluir que o curso, mesmo mantendo a versão de Gaiarsa de que a cidade é a que mais cresce, apresenta uma significativa mudança na historiografia local, ao procurar destacar as novas temáticas, de meados do século XX, como a formação do movimento sindical e a migração.

A historiografia de Santo André, a partir da década de 1990, mesmo abrangendo alguns novos temas, não conseguiu romper com a visão linear e progressista de história para a cidade, criada por Gaiarsa.

Em tal discurso, atrela-se o desenvolvimento de Santo André ao de São Paulo, que também teria se desenvolvido a partir do século XIX, graças à união de quatro fatores - a ferrovia, o café, a imigração e a indústria e a cidade de Santo André passou a ser a mais importante do ABC (São Caetano, São Bernardo do Campo, Diadema, Mauá, Rio Grande da Serra, Ribeirão Pires), pois é a primeira! 


\section{2 - SANTO ANDRÉ NA HISTORIOGRAFIA PAULISTA}

No capítulo anterior pudemos perceber que a historiografia de Santo André está relacionada com a da cidade de São Paulo, a partir do momento em que os historiadores locais resgatam os temas dessa historiografia e os adaptam aos seus interesses.

Assim, é fundamental entendermos como aparece na historiografia paulista Santo André quinhentista e a figura de João Ramalho, bem como a sua relação com os jesuítas, para percebermos o que foi resgatado e de que maneira.

Quando procuramos as primeiras referências historiográficas a esse respeito, podemos considerar que o século XVIII foi o primeiro momento em que os paulistas, a fundação da sua vila, e o seu patriarca - João Ramalho - apareceram como tema na obra de historiadores, porque os paulistas desse período começaram a preocupar-se com o seu passado e passaram a querer modificar a imagem negativa criada pelos jesuítas sobre eles.

Segundo Kátia Abud ${ }^{82}$, o crescimento de São Paulo na segunda metade do século XVIII, levou ao fortalecimento dos comerciantes na Câmara incomodando a antiga elite da terra, já que, durante os séculos XVI e XVII, os "homens bons" eram os donos de terra e de arcos e os comerciantes não tinham acesso à vereança.

Porém, o aumento da influência dos comerciantes em São Paulo, a partir do século XVIII, com a mineração, colocou em segundo plano os proprietários de terras descendentes dos sertanistas.

É justamente nesse momento que apareceram os primeiros relatos sobre os bandeirantes, uma literatura que valorizava os paulistas para se contrapor à chegada dos portugueses que enriqueciam e passaram a ocupar os cargos de administração na vila.

Sob esse ponto de vista, podemos entender as obras de Frei Gaspar da Madre de Deus ${ }^{83}$ e de Pedro Taques ${ }^{84}$, que descendiam dos primeiros povoadores

${ }^{82}$ ABUD, Kátia Maria. O sangue intimorato e as nobilíssimas tradições. São Paulo: FFLCH, 1985. Tese de doutorado.

${ }^{83}$ Gaspar de Teixeira Azevedo, ou Frei Gaspar da Madre de Deus (1715/1800) pertencia às mais antigas famílias de povoadores vicentinos. Aos 16 anos, apresentou-se postulante ao novicio beneditino. Noviço na Bahia, estudou filosofia, história e ciências eclesiásticas. Viajou para Portugal, onde permaneceu algum tempo. Mestre de filosofia e teologia no 
das vilas, dos "bandeirantes" e foram os primeiros a instituir uma história pelo viés paulista $^{85}$.

Frei Gaspar da Madre de Deus, além de ter acesso ao registro escrito e à cultura letrada, pôde consultar os arquivos das corporações religiosas, pois circulou pelos mosteiros entre Santos e Paraíba do Norte.

Seu livro Memórias para a História da capitania de São Vicente, hoje chamada de São Paulo, foi escrito em 1797, reeditado em 1847 pelo Visconde Porto Seguro e teve a sua $3^{a}$ edição em 1921 e usa como fontes os documentos religiosos.

Nessa obra, procurou ressaltar a origem mestiça das famílias povoadoras, valorizando o casamento entre o português e a mulher indígena com status diferenciado.

O ponto de partida da sua história era a descoberta da América e do Brasil ou a fundação da capitania de São Vicente. Suas principais críticas são contra a "Legenda Negra" ${ }^{86}$ criada pelo beneditino Vaissete e o jesuíta Charlevoix, contra os paulistas.

Pedro Taques para a elaboração da sua obra História da Capitania de São

mosteiro fluminense, viu- se em 1743 investido na cátedra de teologia. Em 18 de maio de 1749 , defendeu teses de teologia e história, recebendo o doutorado. Sua biografia está disponível em http://www.novomilenio.inf.br/santos/h0333a11.htm Acesso em 04/08/2010 e http://www.ihgs.com.br/cadeiras/patronos/freigaspar.html Acesso em 04/08/2010.

84 Leme, Pedro Taques de Almeida Pais (1714/1777) estudou no Colégio dos Jesuítas e dedicou-se aos estudos de história e genealogia. Exerceu vários cargos públicos a partir de 1750: escrivão da Intendência Comissária e Guarda-Moria do distrito de Pilar, em Minas; tesoureiro-mor da Bula das Cruzadas nas Capitanias de São Paulo, Goiás e Mato Grosso; guarda-mor de uma das Comarcas paulistas. Pertenceu, também, ao regimento real no posto de sargento-mor. Possui uma vasta bibliografia. (MELO, op. cit., p. 301/302).

${ }^{85}$ No século XVIII, as concepções sobre o passado adquiriram peso no horizonte das elites letradas coloniais, levando à criação da Academia dos Renascidos e à formação da historiografia acadêmica brasileira, que assimilou elementos tanto da historiografia européia, quanto da portuguesa. Dessa maneira, o conhecimento sobre o passado passou a ser elaborado de maneira metódica. Tanto Frei Gaspar da Madre de Deus quanto Pedro Taques fizeram parte dessa academia. Sobre as academias no Brasil colonial, ver KANTOR, Iris. Esquecidos e renascidos. Historiografia Acadêmica Lusoamericana (1724-1759). São Paulo-Salvador: Editora Hucitec/Centro de Estudos Baianos/UFBA, 2004.

${ }^{86}$ Para ver mais sobre esse período consultar as obras de BLAJ, Ilana. "Mentalidade e sociedade: revisitando a historiografia sobre São Paulo colonial" in Revista de História. São Paulo: USP, n. 142/143, 2000, p. 239/260; SOUZA, Laura de Mello e. "Vícios, virtudes e sentimento regional: São Paulo, da lenda negra à lenda dourada" in Revista de História. São Paulo: USP, n. 142/143, 2000, p. 261/276; KANTOR, op. cit.; ABUD, op. cit.. 
Vicente consultou os arquivos da Torre do Tombo e da Secretaria de Estado do Ultramar e Marinha em Portugal, além das fontes eclesiásticas. Nessa obra, procura "branquear" a genealogia das principais famílias paulistas.

Esses dois autores, além de valorizarem o documento escrito e a verdade histórica, construíram uma história excludente, feita por uma pequena parte da população (a nobreza paulista, ligada à posse da terra e aos ofícios militares).

As suas obras mostravam quem eram os "homens bons" que a vinda dos reinóis colocou em risco, realçando os valores de nobreza e não os da nova sociedade burguesa em formação, pregando também a pureza de sangue, excluindo judeus, mouros, mulatos e portugueses, criando, assim, o "paulista", que foi traçado em oposição ao português que estava chegando.

Portanto, tanto Pedro Taques como Frei Gaspar valorizaram as famílias antigas, às quais pertenciam e que queriam recuperar o poder que haviam perdido.

$\mathrm{Na}$ primeira metade do século XIX, a figura do paulista por eles criada, é esquecida, pois esse era o período em que os historiadores se voltaram para a construção da história nacional com a Independência.

Porém, com a proclamação da República, que levou os cafeicultores a controlar o governo federal, essa elite passou a querer construir uma nova versão da história nacional, pelo ponto de vista de São Paulo e acabaram por fundar o Instituto Histórico e Geográfico de São Paulo - IHGSP em 1894, que resgatou a figura do paulista, criada no século XVIII, como sendo o símbolo da República Velha, produzindo uma epopéia paulista mítica e buscando as origens e os heróis fundadores, reescrevendo a história nacional escrita no século XIX, "inventando"87 um passado para São Paulo e o Brasil.

Segundo Antonio Celso Ferreira, a relação entre o Instituto e o governo federal era inquestionável, o que pode ser confirmado pela quantidade de recursos que o governo a ele destinou ${ }^{88}$.

A função do IHGSP era consolidar o discurso identitário regional e federalista de São Paulo, legitimando a hegemonia paulista no governo federal, comprovando a influência do local na produção do conhecimento, conforme Certeau já explanou ${ }^{89}$.

HOBSBAWN, E.; RANGER, T., op. cit..

${ }^{88}$ FERREIRA, Antonio Celso. A epopéia bandeirante: Letrados, Instituições, invenção histórica (1870-1940). São Paulo: Editora da UNESP, 2002.

89 CERTEAU, Michel de. A escrita da história. Rio de Janeiro: Editora Forense Universitária, 1982. 
No Instituto encontramos desde monarquistas católicos, até republicanos americanistas, bem como alguns republicanos envolvidos com questões territorialistas, englobando diferentes setores sociais e políticos, "[...] cada qual trazendo interpretações do passado regional e brasileiro específicos [...] $]^{90}$, porém a maioria era de pessoas de laços sociais bem definidos e cuja fortuna já se consolidara com a expansão capitalista de São Paulo ${ }^{91}$.

Dessa forma, cada autor identifica-se com uma determinada corrente: Amaral Gurgel e Teodoro Sampaio pertenciam à corrente monárquico católica; Washington Luís pertencia à corrente liberal republicana; e Teodoro Sampaio também pertencia ao grupo territorialista.

Segundo Danilo Ferretti ${ }^{92}$, foi a corrente liberal republicana que desenvolveu o discurso sobre a liberdade primitiva do paulista. Já, a corrente territorialista preocupou-se em relacionar o meio físico paulista e o bandeirismo e, por sua vez, foi a corrente monárquico católica que iniciou a polêmica sobre João Ramalho em 1902.

A partir de 1910, há um novo grupo de autores no IHGSP, em que não existe mais a contradição entre ser católico militante e republicano convicto. Desse grupo, Washington Luís era o guia e Afonso de Taunay era um dos seus principais auxiliares. Nesse período, o eixo intelectual passa do IHGSP para o PRP e articulase ao redor do jornal $\mathrm{O}$ Correio Paulistano.

Nesses dois contextos, século $X V I$ e começo do século $X X$, encontramos a referência à vila de Santo André e a João Ramalho de duas formas diferentes e é justamente a maneira como essas questões aparecem em Frei Gaspar da Madre de Deus, Pedro Taques, Amaral Gurgel, Teodoro Sampaio, Washington Luís, Affonso de E. Taunay, entre outros, que é o objetivo principal desse capítulo.

\footnotetext{
${ }^{90}$ FERRETTI, op. cit., p. 220.

${ }^{91}$ FERREIRA, op. cit., p. 102.

92 Ibid, p. 220/221/222.
} 


\subsection{Santo André}

Conforme dito, os dois momentos que destacamos para estudar são aqueles em que Santo André da Borda do Campo aparece na historiografia paulista: o primeiro, no século XVIII, com Frei Gaspar da Madre de Deus e Pedro Taques e, o segundo, no início do século XX, na produção do IHGSP. ${ }^{93}$

No primeiro contexto, as menções à vila de Santo André são positivas. Para Pedro Taques, a vila, aclamada em 8 de abril de 1553, teria sido fortificada para garantir a defesa dos moradores diante dos ataques indígenas, mas não emitiu juízo de valor sobre a mesma.

Com a fundação do Instituto Histórico e Geográfico de São Paulo, no início do século XX, a fundação de Santo André passou a ser um dos temas discutidos. Ao todo foram oito estudos sobre a vila quinhentista. Nesses trabalhos, era constante o uso de fotografia e desenhos, com um forte apelo visual ${ }^{94}$. Os autores publicados na Revista do IHGSP ${ }^{95}$ preocupam-se com a localização da sede da vila, a origem do nome, as características dos seus moradores e da própria vila, bem como com os motivos da mudança para a vila de São Paulo.

Para tentar definir o local da sede da vila, montaram uma comissão e Jaime Cortesão, Washington Luís, Teodoro Sampaio, Taunay, Amaral Gurgel, entre outros, gastaram páginas de suas obras nessa questão.

${ }^{93}$ Há numerosos estudos universitários sobre a região do $A B C$, incluindo Santo André, a partir dos anos de 1960 - com a aceleração do processo de industrialização, do processo migratório interno e do surgimento de uma nova classe operária -, realizados por economistas e sociólogos. Tais obras, relevantes para o conhecimento histórico sobre a região na segunda metade do século $X X$, não serão explorados, pois não colaboraram para a construção da memória social.

94 FERREIRA, op. cit., p. 131.

95 O IHGSP foi estudado por FERRETTI, D. J.. Op. cit; FERREIRA, A. C., op. cit; SCHWARCZ, Lilia M. O espetáculo das raças - cientistas, instituições e questão racial no Brasil - 1870-1930. São Paulo: Companhia das Letras, 1993; MATTOS, O. N. "Afonso de Taunay e o Instituto Histórico e Geográfico de São Paulo" in Revista do IHGSP. São Paulo, v. 88, p. 47/52, 1993; LEONZO, N. "Reduto intelectual na intimidade: O Instituto histórico e geográfico brasileiro" in Revista do Instituto de Relações Sociais e Industriais. São Bernardo do Campo, n. 8, p. 4/51, 1987, etc... 
Para Cortesão ${ }^{96}$, Santo André teria sido fundada no local em que já havia uma povoação, que além de ser um "porto seco", era a fronteira, um local estratégico que vigiava a expansão dos espanhóis do Paraguai, uma espécie de posto alfandegário, que unia os moradores do planalto e servia de base para a expansão portuguesa. Segundo suas palavras:

Esse jogo de trocas e comunidade de interesses devem, a nosso ver, explicar que relativamente cedo um português, João Ramalho, se instalasse no ponto estratégico, onde, galgada a serra, se entrava no campo de Piratininga, pórtico do sertão. Santo André da Borda do Campo, a povoação chefiada por João Ramalho, deve ter sido um porto seco, lugar forçoso de trânsito, espécie de posto alfandegário, colocado na fronteira da serra para o planalto e onde se colhiam os benefícios da portagem, conforme a velha nomenclatura portuguesa $[\ldots] .{ }^{97}$

O problema, para esse autor, é o de não poder definir a sua exata localização, apenas supor qual era o seu rossio ${ }^{98}$, que é uma área maior e que englobava a primeira Piratininga de 1532 e a futura São Paulo.

Para ele, seu termo ${ }^{99}$ também não pode ser definido, e provavelmente incluía toda a área do planalto, o que permaneceu até a fundação de novas vilas na região, quando surgiu a necessidade de delimitar a sua extensão. Porém, durante o período da sua fundação, até a transferência para São Paulo, isso não aconteceu. Devido a

${ }^{96}$ Jaime Cortesão (1884/1960) foi escritor, político e historiador português. No Brasil residiu no Rio de Janeiro, tornando-se professor universitário, especializando-se na história dos descobrimentos portugueses e na formação do Brasil. Em 1952, organizou a Exposição Histórica de São Paulo, para comemorar o $4 .^{\circ}$ centenário da fundação da cidade. Sua biografia está disponível em http://cvc.instituto-camoes.pt/figuras/jcortesao.html Acesso em 03/08/2010; http://www.arqnet.pt/portal/biografias/jaime cortesao.html Acesso em 03/08/2010.

97 CORTESÃO, Jaime. A fundação de São Paulo, - capital geográfica do Brasil. Rio de Janeiro: Livros de Portugal, 1955, p. 136.

98 O rossio é o espaço de posse e uso da Câmara, equivalente a meia légua (Segundo o Dicionário Michaellis, a légua é a antiga medida de extensão, variável segundo os países. No Brasil tem de 6 mil a 6.600 metros. WEISZFLOG, Walter (editor). Michaellis: moderno dicionário de Língua Portuguesa. São Paulo: Melhoramentos, 1998, p. 1238), era a área comum para fruição de todos os moradores e abrangia o espaço público e o privado. Em outras palavras, era a parte central da vila colonial. (Ver: MARX, Murilo. Cidade no Brasil em que termos? São Paulo: Studio Nobel Ltda, 1999; GLEZER, Raquel. Chão de terra e outros ensaios sobre São Paulo. São Paulo: Alameda, 2007).

99 Segundo Raquel Glezer, o termo era a área maior da vila e media 6 léguas ou aproximadamente $36 \mathrm{~km}$, conforme o Regimento de Tomé de Sousa e o foral dado a Martim Afonso de Sousa (Ibid.) 
esse fato, as dimensões exatas da do termo, rossio e da vila não pode ser definidos.

Como o termo de Santo André abrangia todo o planalto, quando o colégio dos jesuítas foi fundado, estava inserido na jurisdição da vila de Santo André.

Teodoro Sampaio ${ }^{100}$, para definir a localização do povoado, usou a argumentação que havia um caminho que ligava São Vicente à Assunção, no Paraguai, que passava pela povoação de João Ramalho e não pela vila de Santo André, chegando a conclusão que teria sido no cruzamento da área geográfica da Borda do Campo ou orla da mata com o caminho para o Paraguai, que ficava, a seu ver, a um quilômetro a noroeste da vila de São Bernardo que existia no início do século XX, no qual teria existido um povoado conhecido por Borda do Campo.

Também Afonso Taunay não sabe a sua exata localização, pois defende que por não terem sobrado as ruínas, apenas se pode deduzir que ficava na região do ABC, provavelmente na região da Fazenda São Bernardo.

A partir desses estudos, o que podemos concluir é que, no primeiro momento, a vila de Santo André compreendia todo o planalto, pois o governo português criou a vila, mas não determinou as suas divisas, englobando, assim, todo o planalto, no qual seriam fundadas novas vilas, mas não a exata localização da sua sede.

Outra preocupação dos historiadores ligados ao IHGSP, além da localização, foi com a origem do nome da vila.

100 Teodoro Sampaio (1855/1937) foi engenheiro, geógrafo e historiador brasileiro. Nasceu na Bahia e era filho da escrava Domingas da Paixão do Carmo e do padre Manuel Fernandes Sampaio. É levado pelo pai, em 1864 para São Paulo e depois para o Rio de Janeiro, onde ingressa no curso de Engenharia do Colégio Central. Ao mesmo tempo, estuda, leciona e é desenhista do Museu Nacional. Em 1886, participa da comissão que realiza o levantamento geológico do Estado de São Paulo e entre 1898 e 1903, foi Diretor e Engenheiro Chefe do Saneamento do mesmo estado. Participou da fundação da Escola Politécnica e foi, em 1894, um dos fundadores do Instituto Histórico e Geográfico de São Paulo. Foi membro também dos Institutos Geográfico e Histórico da Bahia e sócio do Instituto Histórico e Geográfico Brasileiro. Mesmo alinhado ao Partido Conservador no Império, conseguiu inserir-se nas principais instituições de saber criadas na República. A respeito do autor, ver: SANTANA, José Carlos Barreto. "Introdução" in SAMPAIO, Teodoro. O rio São Francisco e a Chapada Diamantina. São Paulo: Companhia da Letras, 2007; COSTA, Luís Augusto Maia. O ideário urbano paulista na virada do século. $O$ engenheiro Teodoro Sampaio e as questões territoriais e urbanas modernas (1886-1903). São Carlos (SP): RIMA, FAPESP, 2003; http://portaldaculturanegra.wordpress.com/2008/08/28/teodoro-fernandes-sampaio/ Acesso em 03/08/2010. 
Jaime Cortesão defende que havia uma ermida no local erguida pelo padre Leonardo Nunes com o nome de Santo André. O que é negado por Teodoro Sampaio, para quem não havia ermida na região que virou a sede de Santo André, pois a de São Paulo teria sido a primeira.

Por sua vez, Washington Luís ${ }^{101}$, concorda com Cortesão, a partir do momento em que usa a Carta de Tomé de Souza de 1553 ao rei de Portugal para defender que a origem do nome da vila foi por causa de uma ermida que teria na região. Assim, a sede da vila seria num lugar ermo e não na povoação de João Ramalho. Dessa forma, João Ramalho não teria morado em Santo André.

Além da preocupação com a origem do nome e a sua localização, os autores também procuraram definir o caráter dos moradores e o aspecto da vila. A respeito dessas duas questões, percebemos que há duas formas de referir-se a Santo André. $\mathrm{Na}$ primeira, quando falam da vila, por ela mesma e no segundo, quando a comparam com a vila de São Paulo. Nesse último caso, há a sua desvalorização para mostrar a superioridade de São Paulo e justificar a mudança da sede.

Jaime Cortesão, ao descrever a cidade por ela mesma, encaixa-se no primeiro grupo, e critica Schimidel, que foi o principal autor a difamá-la, argumentando que por estar vindo da parte espanhola da América, acabou tendo a mesma visão negativa dos jesuítas espanhóis sobre a vila.

Ao contrário de Schimidel, Cortesão, através das Atas de Santo André, define Santo André como sendo uma vila pastora, parecida com as vilas medievais, com

101 Washington Luís Pereira de Souza (1869/1957) era de uma família prestigiada no Império, mas que não pertencia à tradicional elite paulista, pois era fluminense. Advogado de formação, iniciou a carreira pública ao ser nomeado promotor público do município de Barra Mansa, no Rio de Janeiro, renunciou ao cargo para dedicar-se à advocacia em Batatais, no interior de São Paulo. Foi eleito vereador em 1897 e prefeito da cidade de Batatais em 1898. A partir de 1901, estabeleceu-se na capital, casou-se com Sofia de Oliveira Barros, filha do segundo Barão de Piracicaba, união que reforçou sua ligação com a oligarquia paulista e virou sócio do IHGSP. Com o apoio dela, foi eleito deputado estadual pelo PRP em 1903, prefeito da capital em 1914 e governador do Estado em 1920. Ao assumir a prefeitura, em 1914, mandou publicar o maior corpus documental referente à história da cidade, as Atas da Câmara da vila de São Paulo, incluindo as de Santo André da Borda do Campo. Assumiu a presidência da República em 15 de novembro de 1926 e foi deposto pela Revolução de 1930. Viveu os 17 anos seguintes exilado na Europa e nos Estados Unidos e, em 1947, voltou ao Brasil. Historiador e membro da Academia Paulista de Letras, escreveu livros e ensaios sobre a história brasileira. A respeito do autor, ver: DEBES, Célio. Washington Luís (1869-1924). São Paulo: Imprensa Oficial, 1994; DEBES, Célio. "Washington Luís historiador" in Revista do Instituto histórico e geográfico de São Paulo, 1990, vol. 85; http://www.netsaber.com.br/biografias/ver biografia c 1069.html acesso em 03/08/2010. 
muros e casas de taipa, cuja população mameluca era ordeira e "[...] por debaixo dos saios e dos arcabouços rudes desses homens, pulsavam corações, com entranhado amor à liberdade e à dignidade humana, temperado pelo sentimento do dever de obedecer e servir". 102

Amaral Gurgel ${ }^{103}$ e Teodoro Sampaio também criticam Schmidel sobre o que escreveu sobre Santo André. Para eles, Santo André jamais poderia ser um valhacouto de ladrões, conforme Schmidel afirma, pois já era uma vila quando ele passou por lá.

Porém, Sampaio é contraditório ao referir-se a Santo André: percebemos que, para ele, em alguns momentos a vila era contra a idéia de civilização, mesmo que os seus moradores fossem honestos e honrados. Segundo ele, "Santo André, no alto dos campos, mais era uma traição à idéia civilizadora do que uma vila de portugueses [...]". 104

E em outros, era povoada por cristãos e civilizada, conforme afirma no trecho que se segue:

[...] o que foi ou o que devia ter sido a vila de Santo André, como núcleo de população cristã, e como o primeiro despertar da civilização neste lugar, fadado para os mais arrojados cometimentos na conquista e descobrimento dos sertões ocidentais. ${ }^{105}$

Teodoro Sampaio defende que Santo André não foi obra de João Ramalho, mas do jesuíta Leonardo Nunes. A importância de João Ramalho estava em ter originado o movimento povoador no planalto, mas não a vila. Por outro lado, concorda com Cortesão quando este afirma que a povoação era parecida com uma aldeia indígena, como todas as construções da época, conforme verificamos no trecho abaixo:

A povoação, como é de presumir-se, não passaria de certo de uma

102 CORTESÃO, op. cit., p. 194.

103 Leôncio do Amaral Gurgel (1876/1939) foi um comerciante e industrial que nas horas vagas dedicava-se à história, às biografias, às genealogias e ao jornalismo. Foi colaborador no jornal o Comércio de São Paulo, no Estado de S. Paulo, no Jornal do Comércio, na Gazeta, entre outros. Como sócio do Instituto Histórico e Geográfico de São Paulo, escreveu um estudo sobre João Ramalho na revista. (MELO, op. cit., p. 272/273)

104 SAMPAIO, op. cit., p. 229.

105 Ibid., p. 174/175. 
reunião de algumas cabanas cobertas de folha de palma, feitas de taipa de mão a modo dos índios, dispostas ao longo de único caminho então existente, e sem nenhuma construção de caráter duradouro, coisa então comum em todo o Brasil. A ermida ou capela não está averiguado que a tivessem edificado [...] . ${ }^{106}$

E acaba por concordar com Schmidel que, a vila de Santo André, por ser tão miserável, poderia passar por um reduto de bandidos, já que era pequena. Dessa forma, acaba por desvalorizá-la, conforme observa-se no fragmento abaixo:

[...] As mesmas fortificações não passavam, porém, de simples estacadas, a modo dos índios, como o eram nessa época as de Santos e São Vicente, a julgar-se por umas velhas gravuras holandesas do século XVI. Feitas de grossos madeiros com os seus fossos ao redor, essas mesmas cercas ou estacadas, envolvendo umas tantas habitações toscamente construídas, não pouco teriam contribuído para a má impressão que a aldeia produziu no recémchegado, aldeia miserável, semelhando um reduto de bandidos, cujos moradores ausentes deixavam as suas palhoças fechadas por longos dias, talvez ocupados com as suas lavouras, ou empenhados nas duras e repetidas expedições para saltear índios". 107

Ao aproximar-se de Schmidel na descrição de Santo André, acaba por discordar de Frei Gaspar da Madre de Deus, para quem a aldeia tinha várias obras públicas. Para Sampaio, Santo André só devia ter fortificações, que seriam comuns na época.

Teodoro Sampaio conclui que Santo André da Borda do Campo era tão miserável que desapareceu até da memória das pessoas:

Nas margens do Guapituba que flui para o Piratininga, cerca de légua da atual vila de São Bernardo, o viajante debalde procura num trecho de velho muro, de taipa esboroada, acaso esquecida da destruição do tempo, o que Ihe recorde esse baluarte do Alcáide-mor da Borda do Campo. Como se fora edificada na areia movediça onde um sopro de desolação tudo subvertera e apagara, nem mesmo a tradição da vila mameluca se salvou na memória dos raros habitadores destas paragens. É que as cidades também se apagam na vida como se apagam as iniqüidades dos homens. ${ }^{108}$

\footnotetext{
${ }^{106}$ Ibid., p. 178.

107 Ibid., p. 180.

${ }^{108}$ Ibid., p. 239.
} 
Por sua vez, para Afonso Taunay ${ }^{109}$, é difícil falar sobre a vila e os seus moradores, pois há pouca informação a respeito, sabemos apenas que foi a primeira vila do planalto e que, mesmo com todos os seus problemas, representou a civilização e o início da expansão territorial, pois foi um posto avançado da conquista do planalto e, a partir dela, João Ramalho controlava a entrada para o interior e a rota para o Paraguai. Servia, também para abastecer o litoral.

Por outro lado, não procura esconder o caráter dos moradores da vila, mas o ameniza ao argumentar era o resultado do contexto da época. Segundo suas próprias palavras,

${ }^{109}$ Affonso d'Escragnolle Taunay (1876/1958) nasceu em Florianópolis e sua família mudouse para o Rio de Janeiro antes que completasse um ano. Passou a infância e a juventude com a elite conservadora Imperial da capital do país. Pelo lado materno era neto dos barões de Vassouras e, seu pai, Afonso d'Escragnolle Taunay (Visconde de Taunay) foi presidente da província de Santa Catarina, sendo ligado à ala modernizadora do partido conservador. Diplomou-se engenheiro no Rio de Janeiro e mudou-se para São Paulo onde foi professor na escola politécnica e no Ginásio de São Bento. Exerceu inúmeros cargos públicos: diretor do Museu Paulista; diretor do Museu do Estado de São Paulo; encarregado do Governo Federal para reorganizar a Biblioteca e o Arquivo do Ministério das Relações Exteriores; professor na Faculdade de Filosofia, Ciências e Letras, da Universidade de São Paulo (1934-1937). Em dezembro de 1945 foi aposentado por decreto especial em que foi distinguido com o título de Servidor Emérito do Estado de São Paulo. Integrou o Instituto Histórico e Geográfico Brasileiro, o Instituto Histórico e Geográfico de São Paulo, a Academia Paulista de Letras, a Academia Brasileira de Letras, a Academia Portuguesa de História e foi sócio correspondente de diversos institutos históricos estaduais. Taunay, mantendo-se politicamente neutro, conseguiu manter relações com os antigos grupos monárquicos e católicos e com a nova elite republicana. Atuou como ensaísta, biógrafo, romancista, tradutor e lexicógrafo. Dedicando-se aos estudos historiográficos, Afonso Taunay especializou-se como o grande mestre do bandeirismo paulista, do período colonial brasileiro e da literatura, da ciência e da arte no Brasil. Foi também um lexicógrafo de reconhecido mérito, especializado, sobretudo, na terminologia científica. Na Revista do IHGSP e nos Anais do Museu Paulista publicou boa parte de sua obra, na qual percebemos a valorização do bandeirante, do qual se dizia descendente. Há numerosas obras sobre ele, entre elas: ARAUJO, Karina Anhesini. Intercâmbios intelectuais e a construção de uma história: Afonso d'Escragnole Taunay (1911-1929). Franca: UNESP, 2003. Dissertação de mestrado; OLIVEIRA Jr, Paulo Cavalcante de. Afonso d’E. Taunay e a construção da memória bandeirante. Rio de Janeiro: Instituto de Filosofia e Ciências Sociais da Universidade Federal do Rio de Janeiro, 1994. Dissertação de mestrado; MATTOS, Odilon Nogueira de. "Afonso de Taunay e o Instituto Histórico e geográfico de São Paulo" in Revista do Instituto Histórico e Geográfico de São Paulo, v. 88, p. 47/52, 1993; AMARAL, Pedro Ferraz do. "Taunay o historiador da vila de São Paulo" in Revista do Arquivo Municipal de São Paulo. N. 189, p. 3/16. São Paulo, 1977; ELLIS, Myriam, HORSCH, Rosemarie Erika. Afonso d’Escragnole Taunay no centenário do seu nascimento. São Paulo: Secretaria da cultura, ciência e tecnologia, 1977 e sua biografia também está disponível nos sites: http://www.prefeitura.sp.gov.br/cidade/secretarias/cultura/bibliotecas/bibliotecas bairro/bi bliotecas a l/affonsotaunay/index.php? $\mathrm{p}=93$ acesso em $04 / 08 / 2010$ e http://www.netsaber.com.br/biografias/ver biografia c 4830.html acesso em 04/08/2010. 
[...] aos rudes povoadores andréenses dominava a mentalidade dos devassadores da América, dos homens de um áspero século de contendas religiosas, tráfico de escravos, sujeição e extermínio das raças aborigenes do Novo Mundo. Há muito que Ihes precise ser desculpado, atendendo à feição do espírito e ao estado dalma. ${ }^{110}$

A seu ver, os moradores de Santo André tinham o sangue bandeirante da conquista dos índios e da expansão territorial, o que teria gerado a oposição dos jesuítas.

Taunay concorda com Gurgel, Sampaio e Cortesão ao afirmar que a vila era muito pobre, como várias outras da época, podendo até lembrar um reduto de bandidos e seus moradores ficavam ausentes por longos períodos, ocupados com a plantação ou as expedições de apresamento indígena.

Assim, para ele, não é de se estranhar o caráter dos moradores, pois são o resultado do meio, conforme o segmento a seguir:

Para ser alguém morador em Santo André precisava certamente possuir fibra de pouco vulgar energia e despreendimento da vida, que se não coaduna com a brandura e os sentimentos humanitários e altruísticos. ${ }^{111}$

O autor também critica a visão negativa de Schmidel sobre a vila, os moradores e João Ramalho, procurando defendê-los através das atas, que mostram que não eram bárbaros, mas sim pessoas que viviam em constante alerta contra o perigo. Dessa forma, demonstra que a vila era civilizada, a partir do momento que tinha regras que eram seguidas por todos os moradores.

Também concorda com Sampaio na crítica que ele faz a Frei Gaspar por exagerar na quantidade de edifícios públicos em Santo André. Para ele, as casas da vila eram simples, mas, afirma que as fortificações eram mais do que simples estacadas, discordando de Sampaio nessa questão. Para confirmar os seus argumentos usa as Atas da Câmara.

Conclui justificando que por ser um centro apresador de índios muito pobre, não podia deixar de ter moradores bastante violentos.

${ }^{110}$ TAUNAY, op. cit., p. 210.

111 Ibid., p. 177. 
Por sua vez, Washington Luís defende que havia um destino pré-definido para Santo André - ser substituída pela cidade de São Paulo, e é o que percebemos abaixo:

Santo André, porém teria existência efêmera; estava destinada a durar pouco mais de sete anos, e dela não ficariam vestígios no campo, nem na História a não ser o magro volume de atas contendo magríssimas sessões [...]. ${ }^{112}$

Procura minimizar Santo André, colocando que tinha poucos moradores e, menos ainda, "homens bons" e que suas casas simples, estavam destinadas a desaparecer, assim como os seus muros:

$\mathrm{Na}$ vila não havia telheiros nem pedreiros [...]. As casas de Santo André eram cobertas de palha, em cujas paredes só havia taipa de mão, quando as havia. Os seus vestígios no terreno deveriam desaparecer com facilidade. Era a vila cercada de muros, que se desfaziam com as chuvas [...]. ${ }^{113}$

Washington Luís conclui que Santo André da Borda do Campo foi uma das vilas mais insignificantes do Brasil quinhentista e que não teve nenhuma relação com a Santo André atual, tendo desaparecido a partir do momento em que se abriu um novo caminho para o Paraguai em 1560, tornando-a desnecessária.

Dessa forma, podemos perceber que há uma preocupação nos autores paulistas em, por meio das poucas atas de Santo André que restaram ou dos poucos parágrafos de Schmidel sobre a vila, tentar definir a aparência da vila a sua função no planalto, bem como o caráter dos seus moradores e, embora com algumas divergências, a maioria concorda que era bem simples, com casas e muros de taipa e poucas construções públicas e que, além de controlar a rota para o Paraguai, era um centro apresador de índios, cujos moradores tinham um aspecto de "bárbaros", embora respeitassem as regras do mundo "civilizado".

Assim, conforme explanado anteriormente, há duas formas de descrever a vila, comparando ou não com a vila de São Paulo. Acabamos de estudar como a vila foi descrita no segundo caso. A partir de agora, iremos analisar como os mesmos autores irão mudar o seu ponto de vista, ao procurar descrever a vila, a partir de

112 LUÍS, Washington. Na Capitania de São Vicente. São Paulo: Livraria Martins Editora, 1956, p. 70.

113 Ibid., P. 70. 
uma outra preocupação: desvalorizar Santo André, para justificar a superioridade de São Paulo, o que levaria à mudança da sede da vila para as proximidades da casa dos jesuítas.

\subsection{A desvalorização de Santo André para justificar a mudança}

Podemos associar a fundação da vila de Santo André aos interesses estratégicos do governo português de impedir o povoamento do planalto, garantindo a ocupação e defesa do litoral.

Dessa forma, Sérgio Buarque de Holanda na História da civilização brasileira $^{114}$, afirma que ao mesmo tempo em que Tomé de Sousa autorizou a fundação da vila de Santo André da Borda do Campo, ordenou o fechamento do caminho terrestre para Assunção, no Paraguai e proibiu aos jesuítas de se instalarem no planalto. Para ele, a função de Santo André era controlar esse caminho.

O fato de Tomé de Souza ter escolhido João Ramalho para capitão da nova vila, reside na sua grande influência entre os índios da região. Era uma maneira de atraí-lo para o serviço da coroa portuguesa, assegurando a guarda do caminho para o Paraguai e evitando o povoamento do planalto. Dessa forma, garantindo a defesa do litoral.

Aparentemente, havia uma contradição entre fundar Santo André e fechar o caminho para o Paraguai. Para o autor, "[...] O certo, porém, é que essa povoação [...] tinha em mira apartar os portugueses da comunicação com os castelhanos $[\ldots]^{\prime 115}$.

Porém, essa contradição desaparece quando se percebe que a função da nova vila seria evitar o povoamento da região e controlar a passagem para o interior do continente.

Porém, com o fim do governo de Tomé de Souza e o início do de Duarte da Costa, os jesuítas passam a ser permitidos no planalto e, a partir da mudança dos

114 HOLANDA, Sérgio Buarque; CAMPOS, Pedro Moacyr. (direção). História geral da civilização brasileira. Tomo 1 - Época Colonial - Primeiro volume - Do descobrimento à expansão territorial. São Paulo; Rio de Janeiro: DIFEL, 1976. Quinta edição.

115 HOLANDA, S. B.; CAMPOS, P. M. op. cit., p. 127. 
moradores da vila de Santo André para as proximidades da Casa dos jesuítas, o que o primeiro governador geral queria evitar, passou a acontecer: o povoamento do planalto.

A partir desses fatos concretos: a fundação de Santo André e a mudança para as proximidades da Casa dos jesuítas, a historiografia paulista foi construída procurando justificar o porque da vila de São Paulo ter sobrevivido e "destruído" a de Santo André. A argumentação usada foi a que os Ramalhos queriam aumentar a sua vila e os jesuítas, a sua aldeia, porém o aumento de uma atrasava o da outra.

Nesse discurso, o oposto era desvalorizado: enquanto São Paulo representava o moderno, Santo André representava o arcaico. Havia uma dialética entre o bem e o mal, a dos opostos. Na questão da mudança de sede de vila isso aparece de forma mais intensa, a partir do momento em que mostram que havia uma concorrência entre as povoações e que São Paulo só cresceu depois do fim de Santo André. Dessa forma, Santo André não foi vista por si mesma e sim pelo olhar do outro: São Paulo.

Mesmo historiadores no século XXI mantém esse discurso. Nesse caso, podemos citar Cylaine Neves $^{116}$, para quem, a fundação da casa dos padres e o crescimento desse povoado, trouxe a concorrência entre as povoações e essa concorrência levou à mudança de sede de vila em 1560. Segundo suas próprias palavras:

E desta maneira, indo enobrecer outra localidade, acabou o pelourinho de Santo André da Borda do Campo em São Paulo de Piratininga, onde se prolongou e se projetou a vida social, econômica e administrativa da vila desaparecida. ${ }^{117}$

Porém, ao voltarmos ao século XVIII, percebemos que em Pedro Taques não aparece a questão da mudança da sede de vila de maneira conflituosa. Para o autor,

Neste lugar se conservaram os jesuítas e os portugueses na vila de Santo André até o ano de 1560, em que Mem de Sá, governador geral do Estado do Brasil [...], se recolheu a vila de São Vicente em junho do dito ano; e o padre superior daquele colégio, Manuel da Nóbrega, pediu ao governador geral que fizesse transmigrar os

116 NEVES, Cylaine Maria das. A vila de São Paulo de Piratininga: fundação e representação. São Paulo: FFLCH-USP, 2004. Dissertação de mestrado.

117 Ibid, p. 119. 
moradores da vila de Santo André para São Paulo de Piratininga, onde os jesuítas residiam conservando a boa paz e amizade com o rei Tibiriçá que já se achava convertido $[\ldots]^{118}$

O mesmo não ocorre em Frei Gaspar da Madre de Deus que foi o primeiro a colocar a questão da mudança como resultado de um conflito, que resultou na vitória de São Paulo, "com sentimento grande de João Ramalho e seus filhos, cujos intentos eram diametralmente opostos aos dos padres". ${ }^{119}$

Segundo ele, os jesuítas convenceram o governo que era útil mudar a vila de Santo André (o pelourinho, os moradores e o fôro de vila) para São Paulo, pois Santo André era mais fácil de ser atacada e não tinha pároco. A mudança resolveria esses problemas, a partir do momento em que a vila de São Paulo ficava em lugar descoberto, não ocultando a marcha dos inimigos.

Porém, Amaral Gurgel ameniza essa rivalidade, a partir do momento em que expõe que João Ramalho não era inimigo dos jesuítas, idéia que fica clara no extrato:

Residindo em São Paulo, onde ocupara o cargo de vereador e comandante da gente que partia para o sertão, afim de combater os indígenas - isso dentro do predomínio dos jesuítas, fica bem patente que ele não era inimigo dos padres da Companhia de Jesus, nem estes o eram dele. ${ }^{120}$

Ao contrário de Gurgel, para Sampaio, Ramalho era o que mais se opunha aos jesuítas "[...] na cruzada a favor do gentio, quando inauguraram o seu apostolado na América, veio de João Ramalho e de seus filhos". ${ }^{121}$

Jaime Cortesão ${ }^{122}$, resgatando Frei Gaspar da Madre de Deus, usa as Atas de Santo André e as cartas jesuíticas para exagerar na questão do conflito entre as duas povoações, argumentando que as duas não poderiam sobreviver juntas e também para ele, a mudança resolveu o problema da falta de segurança diante dos

118 LEME, Pedro Taques de Almeida Pais. História da Capitania de São Vicente. São Paulo: Melhoramentos. s/ data, p. 73.

119 DE DEUS, op. cit., p. 124.

${ }^{120}$ GURGEL, L. Amaral. Ensaios quinhentistas. São Paulo: Empresa Editora J. Fagundes, 1936, p. 132/133.

121 SAMPAIO, op. cit., p. 191.

${ }^{122}$ CORTESÃO, op. cit.. 
ataques dos franceses e dos tamoios. Porém, acrescentou que Santo André também tinha problemas econômicos.

Gurgel expôs a mesma idéia, porém com outras palavras. Para ele, Santo André atrasava o progresso de São Paulo. Essa idéia fica clara no trecho abaixo:

\begin{abstract}
Passaram-se alguns anos mais, porém Ramalho e os seus não viam com bons olhos o crescente progresso da aldeia de São Paulo. E quanto aos jesuítas, possuindo melhores elementos, sob todos os pontos de vista, além da magnífica situação estratégica de sua povoação, - desejavam, quiçá em beneficio dos habitantes da Borda do Campo, tão sujeitos aos ataques dos indígenas ferozes, que a supremacia de Santo André, por ser mais antiga, passasse para São Paulo. ${ }^{123}$
\end{abstract}

Segundo Sampaio, Santo André não tinha condições de prosperar, pois era mal localizada e sofria a oposição dos jesuítas que, para ele, foram os responsáveis pela expansão da ocupação do planalto. O autor esclarece que:

\begin{abstract}
Santo André da Borda do Campo, na verdade, nunca foi mais do que uma pobre aldeia, fadada a uma vida efêmera e sem glória. Mal situada, exposta aos assaltos dos bárbaros por se achar muito próxima das matas, não contando com a boa vontade da gente do litoral, e, depois da vinda dos jesuítas, que foram os melhores e mais eficazes impulsores do povoamento do país, não contando também com as simpatias destes, a vila de João Ramalho não possuía as condições essenciais de prosperidade nesses tempos". ${ }^{124}$
\end{abstract}

Sampaio argumenta que a vila de Santo André era tão negativa e insignificante que desapareceu completamente.

Para o autor, a decadência de Santo André é proporcional ao crescimento de São Paulo, representante da civilização, que acabou por prevalecer e "A sua rápida decadência e total aniquilamento explicam-se, portanto, pelas mesmas causas que determinaram a fundação e crescimento de São Paulo, cerca de três léguas campo adentro". 125

Dessa forma, uma cidade define-se pela oposição com a outra. Dessa forma, enquanto Santo André representava a violência, São Paulo era a civilização:

\footnotetext{
${ }^{123}$ GURGEL, op. cit., p. 131.

${ }^{124}$ SAMPAIO, op. cit., p. 181.

125 Ibid., p. 181.
} 
São Paulo opunha-se a Santo André da Borda do Campo como uma sentinela à vista, como os pólos opostos de dois sistemas diversos e também opostos. Aquele representava a civilização do Brasil pela redenção do selvagem; este, ao contrário, representava a conquista pelo que esta tinha de mais iníquo e opressor, a escravidão. Um era a persuasão, outro era a força. Anchieta era a brandura, Ramalho era a violência. ${ }^{126}$

Para Sampaio, Santo André representava o mal, a discórdia com as autoridades e os índios, ao contrário de São Paulo. A mudança para São Paulo representava a vitória do bem e foi um progresso para os habitantes do planalto. Para justificar essa argumentação, parte para a comparação entre os dois povoados no que se refere à localização, a relação com os índios e as autoridades portuguesas e conclui que:

A demolição não foi ordenada, nem se tornou necessária. Basta fazer-se um paralelo entre as duas povoações vizinhas, cotejando as boas e más condições de cada uma, para se ficar compenetrado de que a mudança da sede importava num real melhoramento, num assinalado progresso para a população serrana, era, enfim, um fato que se impunha com a veemência das coisas inevitáveis. Santo André, edificada à saída da mata, era exposta aos ataques dos índios; São Paulo, ao contrário, situada mais campo adentro, e a cavaleiro de um espigão de encostas íngremes, protegida por dois fossos naturais como o Tamanduateí e o Anhangabaú, era seguro e inspirava confiança. Santo André representava tradições de guerra com os selvagens, salteados de longa data e reduzidos ao cativeiro, era de fato um pomo de discórdia, e muitas vezes o alvo da vindita dos selvagens ofendidos; São Paulo, ao contrário, fundara-se com os índios, isto é, com o auxílio deles, para lhes servir de asilo, proteção, de um centro de justiça, devia, por isso mesmo, ser o alvo das simpatias e da vigilância do gentio. Santo André não logrou jamais obter a boa concórdia com as autoridades do litoral, as quais não raro lhe levantavam tropeços que o gênio de Ramalho, arrogante, não sabia evitar. São Paulo, ao contrário, recebeu sempre das autoridades e do governador geral do Brasil todo o bafejo. Santo André nunca teve igreja, não conseguiu jamais ter um pároco para o seu serviço religioso, coisa indispensável naqueles tempos. São Paulo, pelo contrário, formou-se sob este influxo, e construiu logo igreja, em torno da qual a povoação se foi desenvolvendo, sob a direção beneficente dos Padres. Assim, portanto, à paz, à segurança, ao bafejo das autoridades, à simpatia do gentio, à influência religiosa deve São Paulo a sua ascendência e preferência sobre a vila do alcáide-mor da Borda do Campo, e só isso basta para explicar a decadência de Santo André que

${ }^{126}$ Ibid., p. 182. 
desapareceu sem deixar vestígios. ${ }^{127}$

Assim, para o autor, a transferência da sede de vila para junto ao colégio dos jesuítas só foi possível, superando a decadência de Santo André e representou a vitória e prosperidade de São Paulo.

Por sua vez, Serafim Leite ${ }^{128}$, usando as Atas de Santo André, também procura provar que São Paulo assimilou Santo André, vencendo a competição entre as duas povoações, o que deixa claro no texto a seguir:

Na sua simplicidade documental, reduz-se tudo ao seguinte: havia duas povoações próximas. Surgiriam competições entre ambas? É possível, como em todas as terras vizinhas. Os documentos não autorizam porém uma conclusão certa. Mas se houvesse, não se poderia levar a mal os jesuítas o concorrer para o triunfo de São Paulo. Seria, historicamente, o primeiro ato do seu lema Nom ducor, duco! (Não hei de andar na órbita de influência dos outros, mas os outros na minha!). Seria também o triunfo mais nobre que consiste, não em aniquilar o competidor, mas em absorvê-lo e dirigir-lhe a atividade. Contudo, o que unicamente se pode afirmar diante da verdade histórica, é que São Paulo encorpou a si a vila de Santo André por esta razão, válida em todos os tempos e em todas as regiões da terra: enquanto Santo André tinha vida precária, exposta aos ataques dos índios, vida difícil em que se 'morria de fome', São Paulo era mais defensável e dispunha de vida para si e para os outros! ${ }^{129}$

Afonso Taunay resgata esse discurso, a partir do momento em que coloca que o resultado da concorrência entre as povoações só terminou depois do fim de Santo André e da vitória de São Paulo, com a fusão dos povoados. Assim, a

${ }^{127}$ Ibid., p. 183/184.

${ }^{128}$ Serafim Soares Leite (1890/1969) foi um padre jesuíta, sacerdote e historiador. Depois de frequentar o Seminário dos Carvalhos (Porto), embarcou para o Pará e dedicou-se ao comércio no Amazonas, onde conviveu com os índios e aprendeu sua língua geral. Em 1914, entrou na Companhia de Jesus, onde cursou letras humanas, filosofia e teologia. Em 1932, começou a composição da História da Companhia de Jesus no Brasil, publicada em dez volumes, que ganhou o "Prêmio Alexandre Herculano", em 1938. Foi sócio honorário da Academia Portuguesa de História, pertenceu a Academia Brasileira de Letras e foi sócio correspondente do Instituto Histórico e Geográfico do Rio de Janeiro. Além da História, dedicou-se, também, à poesia, à novela e aos estudos sociais. Sua biografia está disponível em http://www.pucrio.br/pibic/relatorio resumo2009/relatorio/his/livia u.pdf Acesso em 04/08/2010; http://www.esec-dr-serafim-leite.rcts.pt/escola/projedu/projedu.htm Acesso em 04/08/2010; http://www.cm-sjm.pt/175 Acesso em 04/08/2010.

129 LEITE, Serafim. Páginas de História do Brasil. São Paulo - Rio de Janeiro - Recife: Companhia Editora Nacional, 1937. Biblioteca Pedagógica Brasileira - Série $5^{\mathrm{a}}$ Brasiliana - Vol. 93, p. 88/89. 
mudança teria favorecido Piratininga, trazendo o seu progresso e prosperidade. Porém, para ele, não é possível saber com exatidão os motivos da reunião dos dois arraiais porque isso não apareceu nas atas.

Mas supõe que por Santo André ser uma aldeia pobre, como qualquer outra da época e sem pároco e com pouca defesa, teria surgido a necessidade da transferência para São Paulo.

Para Washington Luís ${ }^{130}$, São Paulo também estava localizada numa região mais defensável e mais favorável para o pastoreio e a agricultura e isso tornou inevitável a união entre as duas povoações, confirmando os argumentos dos outros autores sobre as causas da mudança, da falta de defesa e da dificuldade econômica. Porém, acrescenta que a mudança teria ocorrido a pedido dos moradores e dos jesuítas também.

Assim, conforme percebemos, para a maioria dos autores, foi a rivalidade entre os moradores de Santo André e São Paulo que levou à mudança da vila de Santo André para a vila de São Paulo.

Para eles, havia oposição entre a obra dos jesuítas e a intenção de Ramalho, devido a uma disputa pela mão-de-obra indígena e para controlar a população do planalto, João Ramalho querendo aumentar a sua vila e os jesuítas a sua aldeia, porém o aumento de uma atrasava o da outra.

A partir dessa rivalidade, usaram vários argumentos para desvalorizar Santo André, entre eles a falta de pároco, as dificuldades econômicas e a falta de defesa, que existiam de verdade, mas que eram comuns na época, em qualquer povoado da região. Esses argumentos serviram para justificar a mudança, que é colocada de forma a representar o resultado de uma disputa, que trouxe a vitória de São Paulo e a destruição da rival Santo André.

${ }^{130}$ Luís, op. cit.. 


\subsection{João Ramalho ${ }^{131}$}

Da mesma forma que a vila de Santo André é resgatada de diferentes formas, dependendo dos interesses de quem está pesquisando sobre ela, o estudo de João Ramalho, varia definindo o seu papel e caráter, a partir de um ponto de vista favorável ou não.

Colocar João Ramalho como herói ou vilão, conforme o caso, faz parte de um processo maior de construir os símbolos e os mitos fundantes da nacionalidade, cuja origem data do período colonial, principalmente no século XVIII, quando começou a tentativa de criar uma história para a capitania por Frei Gaspar e Pedro Taques e, a partir do final século XIX e nas primeiras décadas do XX, a burguesia cafeicultora paulista aumentou o culto à paulistanidade.

O grande problema para conhecer melhor o que deveria ser o paulista do seiscentos, como João Ramalho, é que eles não escreveram sobre si próprios e muito menos sobre a fundação da sua vila - Santo André ou São Paulo, não deixando suas memórias.

Os primeiros textos sobre os paulistas são da época da Guerra dos Emboabas, são crônicas e descrições de viagens que serviram de base para a criação da "Legenda negra", que trouxe a visão negativa dos paulistas e de quem os historiadores, posteriormente, irão considerar o primeiro, João Ramalho. A "legenda negra", criada, pelos jesuítas espanhóis (Montoya, Jarque) e posteriormente

131 Há diversas obras sobre João Ramalho. Entre elas: ROSSI, Márcio José. João Ramalho: o precursor de uma geração. Trabalho de evento - resumo - nacional. São Paulo: USP, 2007. CD-ROM; NEVES, João Alves das (diretor e editor). João Ramalho. São Paulo: Revista das comunidades de língua portuguesa. N. 19, 2003; FERLINI, Vera Lúcia Amaral. "João Ramalho: como se índio fosse" in Cadernos Paulistas: história e personagens. São Paulo: Imprensa Oficial do Estado, 2002, p. 134/137; VARGAS, Maria Ester. João Ramalho - Bandeirante de Lafões. Viseu: Tip. Beira Alta Ltda, 2000. Coleção "Homens de quinhentos"; FERRETTI, D. J., CAPELATO, Maria Helena Rolim. "João Ramalho e as origens da nação: os paulistas na Comemoração do IV centenário da descoberta do Brasil" in Tempo, Rio de Janeiro, v. 4, n. 8, p. 67/87, 1999; CRUZ, Júlio (editor). Um olhar sobre Vouzela. Viseu: Edem Gráfico,S.A., 1999; SANTOS, Aldo; VALIM, Ana (pesquisa e texto). João Ramalho: de traficante de índios a nome de medalha. São Paulo: CAPES, $2^{a}$ edição. 1997; RIBEIRO, Laerte M. Magno. 20 gerações de João Ramalho e Bartyra, seus descendentes mineiros de andrelândia e outras grandes famílias. São Paulo: L.M.M. Ribeiro, 1989. 
resgatada por Charlevoix ${ }^{132}$ e Vaisette que ficaram indignados com os ataques paulistas às organizações missionárias.

Segundo Kátia Abud:

Pierre François Xavier de Charlevoix foi autor de um livro
considerado clássico, Histoire du Paraguay, que teve larga
divulgação, a partir da sua publicação em 1757, em Paris.
Charlevoix, padre jesuita que nunca esteve no Paraguai,
fundamentou seu trabalho nas obras de seus confrades, Montoya e
del Techo que tinham vivido boa parte de suas vidas no Paraguai.
Nas mesmas fontes se inspirou o monge beneditino da Congregação
de Saint Maur, Joseph Vaissette ao escrever a História Geográfica,
Eclesiástica e Civil. Ao assumirem a posição de Montoya e del
Techo, Charlevoix e Vaissette exprimem total aversão pelos paulistas
e pelo seu modo de vida [... ${ }^{133}$

Portanto, nessa época, a origem das críticas que João Ramalho recebeu vinha da oposição - dos jesuítas, pois guerreavam pelo uso da mão-de-obra indígena, a partir do momento em que ambos queriam usá-la, porém de formas diferentes.

O cronista jesuíta Simão de Vasconcelos ${ }^{134}$ criticou João Ramalho na Crônica da Companhia de Jesus, de 1663, acusando-o de assassino, excomungado e polígamo, seguindo a tradição de animosidade dos jesuítas do período anterior e que serviu de sustentação para a corrente anti- ramalhista.

Porém, segundo Abud, ainda no século XVIII, a essa visão negativa foi contraposta uma nova, a da "Legenda dourada" que passou a valorizar os paulistas e a sua expansão territorial, construindo uma história para São Paulo e uma visão de história do Brasil em que se considerava o "olhar paulista".

Os dois autores responsáveis por essa mudança foram Pedro Taques e o beneditino Frei Gaspar da Madre de Deus que resgataram positivamente João Ramalho, defendendo que ele não era infame, degredado, mas um cavaleiro.

132 CHARLEVOIX, Pedro Francisco Javier de. Historia Del Paraguay. Madri: Librería General de Victoriano Suárez, 1914.

${ }^{133}$ ABUD, op. cit., p. 92.

134 Simão de Vasconcelos (1597- 1671) nasceu em Portugal e imigrou ainda novo para a Bahia. Foi aluno e mestre no Colégio de Santo Inácio. Voltou para Portugal em 1644 e foi para Roma como procurador da sua Província. Em 1662, volta a Portugal e imprime a sua Crônica. Ao voltar para o Brasil, vai residir no Colégio do Rio de Janeiro, onde vem a falecer em 1671, com 74 anos. (VASCONCELOS, Simão de. Chronica da Companhia de Jesu do Estado do Brasil e do que obraram seus filhos n'esta parte do novo mundo. Lisboa: Casa do Editor A. J. Fernandes Lopes, 1865. Disponível em http://143.107.31.150/bibliotecaPdf/Lt-456.1 Original WEB.pdf Acesso em 08/08/2010). 
Frei Gaspar, baseado no testamento de João Ramalho, defende a tese que João Ramalho era náufrago e que teria chegado à América por volta do ano de 1490, portanto, antes de Colombo.

Para ele, João Ramalho é importante, pois quando os portugueses chegaram em São Vicente, foi ele quem impediu que os guaianazes, liderados por Tibiriçá, atacassem-nos. Dessa forma, para o autor, João Ramalho possibilitou a fundação de São Vicente.

Pedro Taques valoriza o lado guerreiro de João Ramalho - o que o teria levado a fundar Santo André. Segundo ele, João Ramalho foi encontrado em Santos pelos Piratininganos e levado ao seu rei Tibiriçá que, por ter simpatizado com ele, deu-Ihe sua filha Bartira ${ }^{135}$ em casamento. Posteriormente, quando Martim Afonso de Souza aporta em São Vicente, é João Ramalho que o recebe.

A partir do século XIX, passou a predominar a visão negativa de João Ramalho, que foi acusado de infame, assassino, polígamo, caçador de índios, judeu. Nesse período, o seu maior detrator foi Cândido Mendes ${ }^{136}$ na obra Notas para a história pátria ${ }^{137}$ que procurou desmentir Pedro Taques e Frei Gaspar da Madre de Deus, descartando ponto por ponto as suas afirmações nobilitadoras a respeito do "pai dos paulistas". ${ }^{138}$

Percebemos que a personagem histórica João Ramalho assumiu o lugar de primeiro herói, após a proclamação da República e o controle do governo federal pelos cafeicultores paulistas. A representação do bandeirante foi difundida como símbolo incontestável da paulistanidade na busca do primeiro - o pai de todos e o indicado foi João Ramalho.

Dessa forma, a elite paulista usou a história para se legitimar no poder e colocar a história de São Paulo como sendo a do Brasil e um ponto central nesse processo foi a questão da origem da cidade e o seu herói fundador.

\footnotetext{
${ }^{135}$ Seu nome cristão era Isabel.

${ }^{136}$ Cândido Mendes de Almeida (1818/1871), o Visconde de Vieira da Silva, era formado em direito. Porém, exerceu diversas profissões: jornalista, advogado, professor e servidor público (magistrado, diretor de seção da Secretaria da Justiça, promotor público e chefe da seção da secretaria dos Negócios do Império. Exerceu 5 cargos de deputado geral e foi senador entre 1871 e 1881. Sua biografia está disponível em http://www.senado.gov.br/senadores/senadores biografia.asp?codparl=1535\&li=17\&lcab $=1878-1881 \& \mathrm{lf}=17$ Acesso em 10/08/2010.

137 ALMEIDA, Cândido Mendes de. "Notas para a história pátria" in Revista do Instituto Histórico e Geográfico Brasileiro. Rio de Janeiro, parte II, v. 40, p. 277-364, 1877. Disponível em http://www.ihgb.org.br/rihgb/rihgb1877t00402.pdf Acesso em 10/08/2010.

${ }^{138}$ A respeito dessa questão, ver: FERRETTI, op.cit., p. 87/88.
} 
Partindo dessa problemática, colocar João Ramalho como pai fundador era uma questão complicada, pois além de ser uma figura controversa no contexto da apropriação do campo político relacionado ao passado e de existirem poucas fontes primárias a seu respeito, seria valorizar o regional sobre o nacional, o que traria problemas.

Percebemos que o início das discussões sobre João Ramalho foi com as Comemorações do quarto centenário da descoberta do Brasil, na virada do século XIX para o XX, quando autores do IHGSP procuram definir o seu papel no descobrimento do Brasil, dando continuidade às discussões do século XVIII.

A partir desse parecer contrário a João Ramalho abriu-se a polêmica sobre os heróis fundadores de São Paulo e da nacionalidade, colocando em campos opostos os três grupos em que se dividia o Instituto na época, procurando encaixá-lo ou não no panteão desses heróis.

A partir dessa preocupação, em 1902, o IHGSP montou uma comissão ${ }^{139}$ para discutir a respeito da personalidade de João Ramalho e do seu papel na colonização, baseando-se nos testemunhos secundários de cronistas da América portuguesa e acabaram por elaborar uma imagem negativa sobre ele.

Coube ao grupo monárquico católico- Teodoro Sampaio e João Mendes Júnior, herdeiros da historiografia indianista-, o início dessa polêmica sobre João Ramalho, pois queriam conferir ao jesuíta o papel de herói civilizador.

Segundo Maria Helena Rolim Capelato e Danilo J. Zioni Ferretti ${ }^{140}$, a discussão começou procurando estabelecer se ele era analfabeto e judeu e foi proposta por João Mendes $\mathrm{Jr}^{141}$, tendo predominado o lado negativo de João Ramalho, porque no momento os membros dessa comissão estavam voltados para

139 As discussões aparecem na Revista do Instituto Histórico e Geográfico de São Paulo, no volume VII, de 1902. São Paulo: Typographia do Diário Oficial, 1903.

140 FERRETTI, Danilo J. Zioni; CAPELATO, Maria Helena Rolim. "João Ramalho e as origens da nação: os paulistas na comemoração do IV centenário da descoberta do Brasil" in Tempo, Rio de Janeiro, $\mathrm{n}^{\circ}$ 8, pp. 67/87.

${ }^{141}$ Almeida Júnior, João Mendes de (1856/1923) cursou a Faculdade de Direito (1873-1877), doutorando-se em 1879. Foi político militante e presidente da Câmara Municipal da Capital (1881 e 1882), colaborando na imprensa periódica. Tornou-se professor da Faculdade em 1889. Em 1916 foi nomeado ministro do Supremo Tribunal Federal. Em defesa de seus pontos de vista, monarquista e católico, polemizou com os positivistas paulistas. Sua biografia está disponível em http://www.cdpb.org.br/dic_bio_bibliografico_almeidajunior.html Acesso em 10/08/2010. 
a questão indígena, defendendo o modelo de incorporação dos índios baseado na experiência jesuítica, indo contra Pedro Taques e Frei Gaspar da Madre de Deus.

Porém, foi significativa a repercussão contrária a esse veredicto na sociedade paulista do início do século XX, tanto que Manoel Pereira Guimarães ${ }^{142}$ manifestouse contra na própria comissão. Segundo ele, João Ramalho não era criminoso, e muito menos traficante de escravos, relacionando-se bem com os jesuítas e não havia incentivado a hostilidade entre a sua vila e a aldeia de São Paulo de Piratininga, ao contrário do que afirmava a comissão do IHGSP e, com ela, toda a tradição oitocentista.

Um terceiro grupo, liderado por Francisco de Campos Andrade procurou integrar as duas alas mais significativas nas quais estava dividido o IHGSP, no que toca à questão das origens de São Paulo - a dos jesuítas e os que pretendiam reabilitar João Ramalho.

O que podemos perceber, é que o empenho na reabilitação da figura de João Ramalho não visava conferir-lhe nenhuma primazia sobre os pais fundadores, mas fixá-lo ao lado dos demais heróis paulistas.

Verificamos que esse era um debate que procurou qualificar ou não Ramalho e, no qual, predominou a posição de conciliar os heróis (jesuítas e a família de João Ramalho), argumentando que embora sempre em campos opostos, ambos muito contribuíram para a expansão da civilização e a conquista do território, portanto, para a formação da nacionalidade brasileira.

Segundo Maria Helena Rolim Capelato, o que estava por traz dessa conciliação era a construção da figura simbólica do bandeirante e do seu pai fundador - promovendo a marginalização do jesuíta-, a ponto de João Ramalho ser designado como o "primeiro bandeirante". Sem sombra de dúvida esta discussão foi determinante na elaboração de uma imagem positiva e heróica dos paulistas, mediante a relativa marginalização da figura do jesuíta.

Além das discussões na comissão, que acabou por tentar chegar a uma conclusão sobre o assunto, há também um debate entre os historiadores fora do Instituto Histórico e Geográfico de São Paulo, que não conseguiu chegar a um

\footnotetext{
${ }^{142}$ Manuel Pereira Guimarães (1865/1948) era formado em direito pela Faculdade de Direito de São Paulo. Além de exercer as profissões de advogado, promotor e juiz, foi também, historiador e biógrafo. Foi um dos fundadores do Instituto Histórico e Geográfico de São Paulo, em cuja revista encontra-se a maior parte da sua produção. (MELO, op. cit., p. 270).
} 
consenso. È o que podemos verificar ao lermos as obras de Cortesão, Gurgel, Sampaio, Serafim Leite, Taunay, entre outros, que também se preocuparam com as questões a respeito do seu papel e as suas funções na origem de São Paulo.

Para Jaime Cortesão, João Ramalho era um náufrago que chegara por volta de 1510 e o construtor de Santo André, a partir dos seus familiares que formaram um grupo considerável, tornando-o respeitável e o grande líder do planalto, assegurando as trocas comerciais com o litoral. Porém, com a abertura de novos caminhos para o Paraguai João Ramalho e Santo André deixaram de ser necessários e isso teria levado a mudança da sede de Santo André para a casa dos jesuítas e, na nova vila, João Ramalho não se afasta de suas funções, pois ele ajuda na defesa da vila em 1562 e foi chamado para ser vereador em 1564, tendo recusado.

O autor critica os jesuítas, principalmente Simão de Vasconcelos, alegando que foram injustos com João Ramalho, por não terem considerado o seu papel na defesa da cidade (sic), assegurando o domínio português no planalto. Dessa forma, para o autor, João Ramalho era o real fundador de São Paulo e o primeiro brasileiro, através da união com os indígenas e também pelo fato de ter adotado os seus hábitos.

Assim como Cortesão, Amaral Gurgel defende que Ramalho havia chegado por volta de 1510 e que era o patriarca das famílias paulistas. Para ele, a "alma" de João Ramalho era nobre, a partir do momento em que ajudou a construir a rival, São Paulo, e também o Brasil, mesmo depois de terem destruído a sua vila. Em suas palavras:

Ao contrário, porém, ei-lo morando em São Paulo de Piratininga, ditosa rival de Santo André; ei-lo trabalhando com afinco pelo progresso de sua nova vila adotiva, e ei-lo enfim, anos depois, talvez curvado sob o peso respeitável de um século de idade, morrendo cheio de relevantes serviços prestado a uma Pátria que não era a sua, mas de seus numerosos filhos e netos. E então, com intensa lucidez e clarividência próprias da proximidade da morte, talvez ele, antes de cair para sempre no silêncio do Além, divisasse ao longe, envolta nas brumas misteriosas do porvir, a sua querida Piratininga, estender-se a povoar-se, enriquecer-se, progredindo, progredindo sempre, até se transformar num opulento São Paulo cosmopolita astro de primeira grandeza que fulge e por certo fulgirá em todos os tempos com luz, vivíssima, no imenso horizonte da nossa Pátria! ${ }^{143}$

${ }^{143}$ GURGEL, L. Amaral. Ensaios quinhentistas. Op. cit., p. 133/134. 
Esse grande feito de João Ramalho deveria ser suficiente para perdoar todos os seus crimes, pois o seu papel foi fundamental no início da civilização e o gerador do progresso de São Paulo. Para ele,

Pois bem, se Deus perdoa ao delinquente que se regenera, porque razão nós, insignificantes e pequeninos diante do Criador, ousaremos criminar um homem que, se fora culpado, incontestavelmente se reabílitara, tornando-se um dos baluartes da civilização, e muito contribuindo para o inicio fundamental da nossa nacionalidade, pelos excelentes serviços prestados à Capitania de São Vicente? ${ }^{144}$

Segundo Amaral Gurgel, João Ramalho é o "nosso" maior ancestral, um desbravador, o agente da civilização e do progresso nos campos de Piratininga. Todos esses fatores seriam suficientes para nunca o criticarmos:

A maior parte de nossas principais famílias é descendente de João Ramalho, e nós paulistas, tão ciosos das nossas glórias, tão ufanos das nossas brilhantes tradições, não devemos, mesmo que ele fosse um celerado revolver as cinzas venerandas desse nosso antepassado, profanando-as com suposições desonrosas! Não! O que nos compete fazer nesse caso é silenciar, respeitando assim a justiça inflexível da história. Outros que falassem e escrevessem contra João Ramalho; nós paulistas, seus netos - ficaremos silenciosos. ${ }^{145}$

O autor também critica a comissão montada pelo Instituto Histórico e Geográfico de São Paulo em 1902, a partir do momento em que teria discutido pontos irrelevantes a respeito de João Ramalho (ser judeu ou cristão) e afirma que isso não tem importância. Acrescentando, também, que ele não era degredado, excomungado e muito menos infame.

Ao contrário, para ele, João Ramalho tinha um caráter louvável, era inteligente, empreendedor e audaz e São Paulo deve-lhe muito por tudo o que fez, devendo desculpar os seus defeitos, pois muito dos seus atos eram considerados normais na época.

Segundo ele, embora a comissão tenha definido que ele era analfabeto, isso não era um problema, pois isso era comum no período e esse fato não o impediu de

\footnotetext{
144 Ibid., p. 52.

145 Ibid., p. 124.
} 
ter cargos importantes nas duas vilas.

Teodoro Sampaio não tem uma visão tão otimista de Ramalho como a de Gurgel e Cortesão. Para ele, Ramalho era um traficante de escravos e aventureiro, que teria chegado entre 1512 e 1571 e não um náufrago, que não possuía sãos princípios, o que teria acabado por gerar a rivalidade com os jesuítas, chegando também a questionar se existe uma verdade a respeito do seu caráter, pois para uns era criminosos, infame e inimigo da religião e, para outros era audaz e valente.

Serafim Leite tem visão oposta a de Sampaio, aproximando-se de Amaral Gurgel a respeito do seu caráter, pois para ele, João Ramalho e Bartira são o Adão e Eva do Brasil, conforme podemos verificar no trecho a seguir:

\begin{abstract}
O primeiro Jesuíta que pisou terras de América e escolheu sítio e mandou fundar o colégio de São Paulo de Piratininga, que é o mesmo que dizer a cidade de São Paulo, na sua excursão apostólica por estas regiões, poucos meses antes dessa mesma fundação, quando aqui se ouvia apenas o rumorejar dos ventos na floresta, olhou para aquele grupo humano inicial, o Adão e Eva da gente de São Paulo, João Ramalho e Isabel, e declara isto, que é mais do que uma esperança, porque foi uma profecia: - Nele e nela e em seus filhos esperamos ter grande meio para a conversão destes gentios! $!^{146}$
\end{abstract}

Dessa forma, João Ramalho teria contribuído para a origem da "raça" paulista, juntamente com Nóbrega e Anchieta.

A síntese e cristalização de uma versão final de todas essas discussões sobre João Ramalho ocorreu com Afonso Taunay ${ }^{147}$, que não mediu esforços para elogiar João Ramalho, na obra João Ramalho e Santo André da Borda do Campo, que foi encomendada pela prefeitura de Santo André na época da comemoração do quarto centenário da suposta fundação da cidade, para quem Ramalho teria sido o criador da "Terra mãe dos paulistas", a partir do momento em que foi um dos primeiros colonizadores e um verdadeiro herói.

Porém, não nega que ele era um traficante de escravos e polígamo, diluindo a sua culpa com a argumentação de que havia vários outros na época que faziam o mesmo e afirmando que foi dessa forma que se tornou importante na região.

\footnotetext{
146 LEITE, Serafim. Páginas de História do Brasil. São Paulo - Rio de Janeiro - Recife: Companhia Editora Nacional, 1937. Biblioteca Pedagógica Brasileira - Série $5^{\mathrm{a}}$ Brasiliana - Vol. 93, p. 95/96.

${ }^{147}$ TAUNAY, op. cit.
} 
Afonso Taunay procurou definir também a sua personalidade e funções com as poucas informações que existem a seu respeito e o que pôde deduzir das atas de Santo André é que tinha várias funções, transformando- o no grande patriarca dos paulistas, no pai dos bandeirantes,

"[...] a figura do Patriarca Povoador, tronco da progenie extraordinaria dos calções de couro, da 'raça de gigantes' de Augusto de Saint Hilaire?" 148 e que "[...] poderia a geração do alcaide e guarda-mór do Campo, orgulhar-se de seus feitos e proclamar quanto fôra obreira da vastidão territorial brasileira". ${ }^{149}$

Seu posto avançado era o que defendia o planalto e que deu impulso para a expansão territorial. Dessa forma, foi o fronteiro mor da civilização, através do domínio do meio ambiente, tornando-se o principal representante da coroa portugusa no planalto, líder de um grupo grande, composto de índios, mamelucos e portugueses, porém com costumes indígenas:

E presidindo a êste movimento inicial da entrada paulista pelo Brasil a dentro, é João Ramalho o pró-homem, o patriarca das bandeiras prodigiosas, anexadoras de milhões de quilómetros quadrados castelhanos, a fé dos tratados - ao nosso patrimônio nacional. ${ }^{150}$

Washington Luís repete argumentos de outros autores. Segundo ele, Ramalho foi um dos primeiros que chegou ao Brasil, entre 1512 e 1517, mas não se sabe o porquê. O autor também coloca a contradição a respeito do seu caráter, resgatando o seu lado bom e também contradizendo Ulrico Schmidel, valorizando a sua força e influência, tanto entre os índios quanto com as autoridades portuguesas. Para ele, mesmo tendo defeitos, suas qualidades os superam.

Um ponto interessante a destacar, que aparece em Afonso Taunay e Washington Luís, é a ênfase que esses autores fazem em destacar que João Ramalho não era judeu, mas sim, cristão. Provavelmente porque não estavam interessados em ter "o pai dos paulistas" que fosse judeu, numa época de antisemitismo, que foi o começo do século $X X$.

148 Ibid., p. 206.
149 Ibid., p. 213.
150 Ibid., p. 211. 
Outra questão discutida a respeito de João Ramalho é sobre a sua relação com os jesuítas. Para Teodoro Sampaio os atritos foram constantes. No trecho abaixo, Sampaio defende que Santo André não favorecia a catequese e os jesuítas, por sua vez, eram contra o tráfico de escravos:

\begin{abstract}
Explorada a região e conhecida a índole dos seus habitantes, os Padres da Companhia, ao iniciar o seu apostolado no Brasil meridional, tinham que escolher com esmero e sumo tato o terreno onde a boa semente devia frutificar. Tinham verificado que em Santo André o lugar não era propício ao seu santo ministério. João Ramalho imprudentemente se indispusera com eles logo de princípio. Fez-se inimigo e perseguidor dos missionários, pois, cedo, reconheceu neles os adversários mais temíveis contra o gênero de negócios a que até ali se entregara em tropeços. Protetores dos índios, como sinceramente se declaravam os delegados do Padre Nóbrega, não podiam nutrir a esperança de obter o apoio e proteção do mais poderoso e destemido dos traficantes de escravos. ${ }^{151}$
\end{abstract}

Ao contrário de Sampaio e Washington Luís, Serafim Leite defende que as relações eram boas, conforme podemos perceber no extrato a seguir:

O mais extraordinário porém de toda esta carta é o reconhecimento explícito da função cristã do próprio Ramalho, naqueles tempos ainda indecisos e tumultuários do Brasil infante, função talvez inconsciente da sua parte, mas conseqüência da sua raça portuguesa, impregnada por muitos séculos de um catolicismo forte. O grito de alma de Nóbrega ao futuro mestre de D. Sebastião para intervir na regularização da vida de João Ramalho deveria ter raízes profundas no amor desta terra. Nas atas de Santo André achamos às vezes a recomendação das autoridades maiores para que se cumpra tudo o que ordenar o capitão a alcaide-mor João Ramalho 'em prol e serviço de Deus e de El-rei nosso senhor'. Como esta frase clássica se ilumina agora de uma nova luz, bem diferente do que estávamos acostumados a ouvir, quando vemos o grande espírito de Manuel da Nóbrega afirmar esta coisa maravilhosa e inaudita que Ramalho, apesar de viver como vivia, conservou esta terra até agora, por causa de Deus. ${ }^{152}$

E mais, para ele, João Ramalho era o "Paladino de Cristo", tendo sido responsável pela manutenção da catequese no planalto e a mudança para a casa dos jesuítas prova que as relações eram boas. Assim, para ele, não podemos concluir que os atritos foram constantes.

${ }^{151}$ SAMPAIO, op. cit., p. 181/182.

152 LEITE, op. cit., p. 96. 
Portanto, para Serafim Leite, as relações eram boas entre Nóbrega e João Ramalho, pois "O P. Manuel da Nóbrega ouviu-o e compreendeu-o. Ambos eram feitos para se entenderem. Deveria ter agradado à decisão e iniciativa do grande Jesuíta a rudeza beiroa daquela alma [...]" 153

Cortesão segue a mesma linha de raciocínio. Porém, acrescenta o fato de que foi Nóbrega quem conseguiu acabar com essa rivalidade, pois sua aldeia de Piratininga estava no termo de Santo André. É o que fica claro nessa fala:

[...] Não se trata, ao que pensamos, dessas ou simplesmente de tais razões, mas, sim, dum discreto tributo de vassalagem ao chefe incontestável do Campo, dentro de cuja alçada penetrava. Terá sido mais uma das habilidades do Padre Nóbrega: lisonjear o fero Alcaide-mor da vila de Santo André, dentro de cujo termo se incluía a aldeia de Piratininga. ${ }^{154}$

Assim, para ele, como Piratininga era um bairro de Santo André, o Padre da Nóbrega foi obrigado a ser político com João Ramalho. Mesmo assim, Cortesão conclui que:

[...] Mas as relações entre a Companhia e João Ramalho, salvo breves períodos de acalmia, foram declarada ou tacitamente más, embora o padre Nóbrega se esforçasse, com rara compreensão e tino político, por suavisá-las. A resistência de João Ramalho a aceitar a severa disciplina dos jesuítas estava na razão direta da sua indianização e prestígio de chefe tribal, de cuja bárbara soberania vai ser deposto pela Companhia de Jesus. ${ }^{155}$

Para Cortesão, a rivalidade começou com a fundação do colégio dos jesuítas, pois o colégio ameaçava a autoridade de Ramalho e a precária vila de Santo André e ela levou à derrota de Santo André pela inteligência superior dos jesuítas.

Para Gurgel, deve-se destacar o papel de Ramalho sem descaracterizar o dos jesuítas, alcançando, além da verdade histórica, o equilíbrio "divino" entre Ramalho e os jesuítas. Esse equilíbrio é a união entre o civil e o religioso que sela o destino das vilas. Para ele,

\footnotetext{
153 Ibid., p. 91.

154 CORTESÃO, op. cit., p. 205.

155 Ibid., p. 139.
} 
João Ramalho era o rústico e possante arado que cavava, preparando a terra; o jesuíta era o semeador paciente, pré-destinado, santo e despido de ambições mundanas, que viera espalhar a

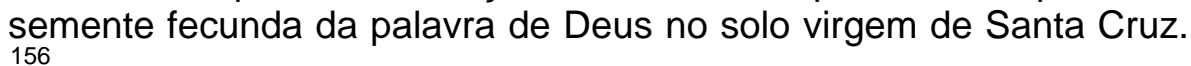

Para Gurgel, a origem do problema era a disputa pela mão de obra indígena e a rivalidade entre as aldeias foi vencida por São Paulo por ser melhor localizada.

Taunay concorda com Gurgel de que a causa da oposição entre os jesuítas e João Ramalho era a disputa pela mão-de-obra indígena e que a mudança para São Paulo representou a vitória dos jesuítas e de São Paulo.

O autor critica Gaspar e Vasconcelos na crítica que fazem à João Ramalho. Por outro lado, analisa e justifica a visão negativa que os jesuítas tem sobre João Ramalho, mas sem deixar de defendê-lo.

Para o autor, a origem da oposição entre eles está na escravidão indígena e, nessa disputa, enquanto os jesuítas representam a civilização, João Ramalho seria a barbárie. Portanto, com a mudança para junto do Colégio, houve a vitória da civlização sobre a barbárie:

Segundo Afonso Taunay, como o problema era a escravidão indígena, a submissão de João Ramalho diante dos jesuítas, fez com que perdesse a influência, sendo por eles derrotado.

Ele defende que o problema para se entender o que teria ocorrido, é que só restaram as vozes dos jesuítas e não a dos andreenses e nas atas não se encontra essa oposição. Mesmo assim, João Ramalho obedece às ordens régias, muda-se para a junto da casa dos padres de Piratininga e mora próximo aos seus inimigos:

Também questiona se João Ramalho teria perdido tanto assim a sua influência com a mudança para São Paulo ou teria feito acordo com os jesuítas, que foram espertos na tentativa de agradar o rival. Porém, recusou-se a morar em Piratininga. Segundo suas palavras:

Habeis como sabiam ser os jesuitas trataram de agradar ao rival vencido, quanto Ihes era possível. Assim Ihe arranjaram ou pelo menos não se opuzeram a que the outorgassem o cargo de capitão-mór de S. Paulo [...]. ${ }^{157}$

\footnotetext{
${ }^{156}$ GURGEL, op. cit., p. 91/92.
}

157 TAUNAY, op. cit., p. 199. 
Washington Luís também resgata a questão de que a relação com os jesuítas nem sempre foi desfavorável, já que, para ele, Ramalho ajudava a catequese:

Esta carta, só a pouco tempo publicada, revela de modo a não deixar dúvida, que João Ramalho, não embaraçava a catequese jesuítica, e que, ao contrário, deixava o seu filho mais velho acompanhar e guiar, no sertão, o Padre Manoel da Nóbrega, para mais autorizar o ministério religioso ${ }^{158}$

No ano de 1553, o Jornal Folha da Manhã ${ }^{159}$ publicou uma série de artigos a propósito do quarto centenário de Santo André, escritos por Afonso Taunay, mostrando que a discussão sobre as origens da cidade de Santo André saia do meio acadêmico e ganhava o público alfabetizado, através de um "porta voz" da academia.

Há também vários poemas dedicados a João Ramalho. No jornal A Gazeta, de 9 de julho de 1957, há uma Ode a João Ramalho ${ }^{160}$. Nela, podemos perceber, que o autor considera João Ramalho o Grande Patriarca dos paulistas:
[...] Senhor da gente paulista
É vosso o chão que pisamos!
Em cada canto da terra
Existe a gota de sangue
Que semeastes na neblina
Das manhãs de nossa raça
É vossa a terra que dorme
Sob a pedra das calçadas
São vossas as paliçadas
De pedra cal e cimento
Que vossos netos ergueram
Contra o cinzento dos céus
É vossa a glória inda viva
De vossos filhos bronzeados
Corações que renasceram,
Do coração que trouxestes
Sobre as ondas que apagaram
Vossas pegadas na praia
Corações pulsando heróicos
Entre os gibões e o infinito
Corações onde vivia
O sangue do vosso sangue

\footnotetext{
158 LUís, op. cit., p. 121.

159 Os artigos estão disponíveis na Hemeroteca do Museu de Santo André Dr. Octaviano Gaiarsa, pastas 101 a 104.

160 Hemeroteca do Museu Dr. Octaviano Gaiarsa, op. cit..
} 
Senhor da gente paulista,

É vosso o chão que pisamos,

Hoje é mais alto o planalto

E vossos olhos contemplam

Dos olhos de vossos netos

O novo dia que surge,

Dia que nasce do dia

Que o milagre fez nascer

Manhã que veio da noite

$\mathrm{Na}$ alvura das velas pardas

E pôs a flor da saudade

Nos cabelos de Bartira!

Senhor da gente paulista!

Renasceis em vosso povo.

Sois vós que vindes de longe

É vosso o chão que pisamos.

A outra questão chave é a discussão sobre a relação com os jesuítas. Enquanto Sampaio defende que as relações entre os dois grupos sempre foi ruim e que a fundação de São Paulo esteve apenas ligada à Igreja; Serafim Leite e Jaime Cortesão defendem que as relações eram boas. Por sua vez, para Gurgel, Taunay e Washington Luís, as relações foram variáveis. Esses últimos, procuraram conciliar os dois lados envolvidos.

De maneira geral, a recuperação da memória de João Ramalho pela historiografia paulista do início do século $\mathrm{XX}$, foi uma questão polêmica, mas que tinha um objetivo claro: definir se ele era a figura certa para representar a fundação de São Paulo e ser a origem do paulista e do bandeirante. A maioria dos autores, Cortesão, Gurgel, Serafim Leite, Taunay, Washington Luís, entre outros, procurou retratar todas as suas ações negativas, justificando-as como sendo fruto da época e irrelevantes diante das suas ações nobres, enquanto que Teodoro Sampaio, junto com o grupo católico do IHGSP, foi o que mais o desqualificou.

\subsection{Continuidade entre as épocas}

Para a maioria dos autores estudados, em 1560 foram transferidos o foral, o pelourinho e os moradores da vila de Santo André para a vizinha povoação de São Paulo de Piratininga e em São Paulo se prolongou e se projetou a vida social, econômica e administrativa da outra vila. 
Cortesão usa as atas para provar que os moradores de Santo André mudaram- se para São Paulo. Verifica os nomes de todos os cidadãos que existiam nas últimas atas de Santo André e nas primeiras de São Paulo e comprovou que ocorreu a mudança de sede de vila, pela continuidade de muitos nomes e pela presença e importância de João Ramalho no fortalecimento da vila de São Paulo.

Para ele, antes da vila de Santo André, existira uma vila fundada por Martim Afonso de Souza em 1532. Em 1553, os moradores dessa primeira vila de Martim Afonso, foram transferidos para a nova vila, a de Santo André, recém fundada. Assim, Santo André seria o segundo ato da fundação de São Paulo. Para ele,

[...] Santo André da Borda do Campo foi o segundo ato na longa e dramática história da fundação de São Paulo. Sem aquele povoado, a fundação dos jesuítas não poderia subsistir. Os moradores da Piratininga de Martim Afonso tiveram que derramar-se pelos campos, congregar-se de novo e amadurecer em Santo André, para com nova pele e nova alma se tornarem dignos de ser paulistas. Na verdade aquele rude burgo foi a indispensável e áspera escola de fronteiros, com a paixão da liberdade, donde iriam sair os bandeirantes. ${ }^{161}$

A sua principal argumentação é que São Paulo foi fundada em três atos: o primeiro, com a vila de Martim Afonso de 1532; o segundo com a fundação de Santo André da Borda do Campo em 1553; e o terceiro, com a fundação da Casa dos Jesuítas em 1554. Dessa forma, a origem da vila de São Paulo, com a conseqüente mudança de sede da vila de Santo André para esse povoado, foi o terceiro ato da sua própria fundação. Para ele, Piratininga, Santo André e São Paulo são a mesma vila.

Também para Amaral Gurgel, houve continuidade entre as vilas de Santo André da Borda do Campo e São Paulo, a partir do momento em que João Ramalho continua ocupando cargos importantes em São Paulo, como o de capitão da guerra contra os tamoios em 1562.

Igualmente para ele, Santo André teria sido uma transição para São Paulo e o próprio João Ramalho agira na mudança de sede e provavelmente assinado a petição solicitando a mudança.

O autor também defende que São Paulo fundou-se em três atos, porém a continuidade é entre São Vicente, Santo André e São Paulo e não mais entre

${ }^{161}$ CORTESÃO, op. cit., p. 195. 
Piratininga, Santo André e São Paulo.Segundo o autor,

\begin{abstract}
Estava pois, em terras do futuro São Paulo, com a fundação da vila vicentina, plantada a primeira semente, que havia de vicejar a florescer, subindo a temerosa serra do Paranapiacaba, numa experiência transitória, com a fundação de Santo André da Borda do Campo, para afinal pouco depois firmar-se definitivamente nos Campos de Piratininga, quando se fundou a vila de São Paulo - a verdadeira célula maravilhosa que, pela bravura e valor dos seus filhos, criou geograficamente boa parte da grande Pátria de que hoje nos orgulhamos. ${ }^{162}$
\end{abstract}

Da mesma forma, Teodoro Sampaio argumenta sobre a mudança da sede de vila. Para ele, ela teria ocorrido de forma natural, com a população de São Paulo englobando a de Santo André. No fragmento a seguir, podemos confirmar a sua argumentação:

[...] Mudada, porém, a sede da vila para São Paulo, onde já havia maior desenvolvimento e Igreja, a população de Santo André foi-se aos poucos dispersando e na quase totalidade se transferiu para ali, ficando as terras em abandono e devolutas. Em 1571, já da extinta Vila de Santo André poucos vestígios havia [...]. ${ }^{163}$

Completa a sua explanação realçando a insignificância de Santo André da Borda do Campo, que teria facilitado o seu desaparecimento, sem precisar derrubála.

Afonso Taunay usa outros termos para dizer o mesmo, a fusão das vilas. Mas, afirma que é difícil saber com exatidão o que ocorrera, pois as atas não falam desse projeto de reunião dos arraiais e da extinção da vila de Santo André.

Segundo Washington Luís também ocorreu a mudança de sede das proximidades da ermida para próximo à igreja (sic), argumentando que isso aparece tanto nos documentos civis quanto nos religiosos, mesmo com a dificuldade para se saber com certeza o que houve pela falta das últimas atas de Santo André e das primeiras de São Paulo entre 1560 e 1562 e do foral da vila de Santo André.

Dessa forma, podemos concluir que, para os autores estudados, a mudança de sede de vila de Santo André para próximo à casa dos jesuítas é vista como natural, diante das dificuldades de Santo André e representa a vitória de São Paulo.

162 GURGEL, op. cit., p. 210.

${ }^{163}$ SAMPAIO, op. cit., p. 256. 
Nessa lógica, o destino de Santo André era pré-estabelecido ao fracasso e de ser apenas uma etapa transitória, como se os moradores daquela época tivessem consciência desse fato.

Ao concluir esse capítulo, podemos perceber que a forma com que a historiografia paulista fez alusão a vila de Santo André e a João Ramalho, foi sempre pelo olhar paulista. Visão essa, que a historiografia de Santo André procurou romper, conforme vimos no capítulo anterior.

Cada cidade, ao construir a sua memória e a sua história procurou dar a sua versão dos fatos. E, no caso de Santo André, procurou as questões que eram as mais convenientes da historiografia paulista, apagando o que não era apropriado aos seus interesses. E, foram justamente essas questões que trabalhamos nesse capítulo.

Resta agora saber como aparecem nas fontes quinhentistas a personagem de João Ramalho e a vila de Santo André da Borda do Campo, bem como as causas que teriam levado à mudança da sede da vila e é isso que iremos trabalhar no próximo capítulo. 


\section{3 - SANTO ANDRÉ NAS FONTES QUINHENTISTAS}

Nos capítulos anteriores vimos várias referências às fontes quinhentistas que os historiadores fizeram ao trabalharem com a vila de Santo André e com João Ramalho e percebemos que, muitas vezes, a mesma fonte é usada para atingir fins diferentes, conforme a leitura que os autores fazem desses documentos e são justamente elas que trabalharemos nesse capítulo: as atas das vilas quinhentistas de Santo André e de São Paulo, as cartas jesuíticas, os relatos de cronistas e viajantes, entre outros.

Como Santo André e João Ramalho deixaram poucos registros e na maior parte das vezes, são os dos seus opositores - os jesuítas e Schmidell-, deve-se, através deles, procurar preencher as lacunas e tentar montar o seu perfil e o da vila.

\subsection{Santo André}

A prova concreta da existência da vila são as atas que estão depositadas no Arquivo do Município de São Paulo ${ }^{164}$, que foram traduzidas na prefeitura de Washington Luis e que estão impressas ${ }^{165}$.

Os historiadores ligados ao IHGSP, estudados no capítulo anterior, ao referirem-se a Santo André, resgataram Charlevoix, que em sua narrativa procura desvalorizá-la. Encontramos na sua obra, a argumentação de que São Paulo tinha um obstáculo às suas conquistas espirituais: a colônia vizinha, em que o sangue português se misturava ao dos índios, saindo uma geração perversa, a qual recebeu o nome de mamelucos, referindo-se a Santo André como "manancial da corrupção".

O foral de Santo André desapareceu, como vários outros documentos da época. Dessa forma, temos que inferir a respeito da sua fundação através de outros documentos e os dois que citam a fundação da vila são a carta de Tomé de Souza

\footnotetext{
${ }^{164}$ O Arquivo Histórico Municipal Washington Luís de São Paulo localiza-se na Praça Coronel Fernando Prestes, 152 - Luz.

165 Atas da Câmara de Santo André da Borda do Campo (1555-1558). Publicadas em: TAUNAY, A. de E. Op. cit., p. 261-320.
} 
ao monarca português ${ }^{166}$ e a carta de São Vicente do Padre Manuel da Nóbrega ao Padre Luiz Gonçalves da Câmara de 15 de junho de $1553^{167}$. Na primeira, o governador-geral informava que havia ordenado na capitania de São Vicente três vilas e a primeira era a de Santo André:

[...] Hordenei outra villla no começo do campo desta vila de São Vicente de moradores que estavão espalhados por elle e os fiz cerquar e ayuntar, pera se poderem aproveitar todas as povoações deste campo; e se chama a villa de Santo André, porque honde a cituey estava hûa ermida deste apostollo e fiz capitão della a lohão Ramalho naturall do termo de Coimbra que Martim Afonso ya achou nesta terra quoando ca veyo. Tem tantos filhos e netos bisnetos descendentes delle ho, non ouso de dizer a $\mathrm{V}$. A., não tem cãa na ${ }_{168}$ cabeça nem no rosto e anda nove leguoas a pe antes de yantar [...].

Essa carta cita o nome de Santo André - explicando o significado desse nome- e o nome de João Ramalho, acrescentando que a sua fundação significou a união de três povoações.

$\mathrm{Na}$ Carta de Nóbrega, porém, encontramos o desejo de unir três povoações por motivos religiosos. Nela não aparecem os nomes de Santo André e de João Ramalho, e mesmo assim, os historiadores deduzem que seja Santo André pela data e localização: "E pelo Campo, daqui doze leguas, se queren ajuntar tres povoações numa, para melhor aprenderem a doutrina cristã e mostram grande fervor e desejo de aprender e que Ihes preguem [...]". ${ }^{169}$

A respeito do aspecto da vila e o dos seus moradores, as principais fontes utilizadas pelos autores são os relatos do viajante Schmidel e a carta de Anchieta de $1^{0}$ de setembro de $1554^{170}$.

${ }^{166}$ A Carta de Tomé de Sousa de 1 de junho de 1553 foi publicada em AZEVEDO, Pedro de. "A instituição do governo geral" in DIAS, Carlos Malheiro (Dir.). História da Colonização portuguesa no Brasil. V. 3: a Idade Média brasileira (1521-1580). Edição Monumental Comemorativa do Primeiro Centenário da Independência do Brasil. Porto: Litografia Nacional, 1924. P. 179-180.

167 Ibid, p. 180.

168 A Carta do Padre Manuel da Nóbrega de 15 de junho de 1553 foi publicada em LEITE, S. Novas Cartas jesuíticas (de Nóbrega a Vieira). São Paulo; Rio; Recife; Porto Alegre: Companhia Editora Nacional, 1940, p. 39 a 50.

169 lbid, p. 44

${ }^{170}$ A Carta do Padre José de Anchieta de $1 .^{\circ}$ de setembro de 1554 ao padre Inácio de Loiola que foi extraída do livro Cartas, Informações, fragmentos históricos e sermões do Padre Joseph de Anchieta, S. J. (1554-1594). Rio de Janeiro: Civilização Brasileira S.A., 1933. p. 35-61. 
Schmidel compara a vila a uma "cova de bandidos". Porém, não podemos nos esquecer que ele vinha do Paraguai e estava influencidado pela visão que os jesuitas espanhóis tinham a respeito dos portugueses:

Nos fuimos de allí y llegamos a um lugar que pertenecía a los cristianos cuyo capitán era Juan Ramallo. Por suerte nuestra no estuvo a La sazón em este lugar, que a mi me parecia uma cueva de ladrone. El dicho capitán se encontraba entonces com otros cristianos em San Vicente, para cumplir ciertos tratos que tenían entre ellos. Los índios, entre los cuales viven ochocientos cristianos em dos lugares, están sujetos AL Rey de Portugal y em poder Del dicho Juan Ramallo, quién, según dice, lleva cuarenta años em lãs Indias, gobernando, guerreando e pacificando El país, por lo que, em justicia debía de regirlo antes que nadie. Y como no lo consiguió. Tienen guerra los unos contra los otros. Este Ramallo puede reunir em um solo dia cinco mil índios, em tanto que El Rey solo junta dos mil; tan grande ES El poder qu tiene em este país. Cuando llegamos AL dicho lugar, estaba allí El hijo Del dicho Ramallo, AL que tuvimos que temer más que a los mismos índios, por bien que nos recibiera. Pero como todo nos salió bien, dimos gracias a Dios Todopoderoso, contentos de habermos escapado sin peligro. ${ }^{171}$

Em algumas edições o nome citado é "Joan Reinveille"172, que de forma interessante acabou sendo traduzido como João Ramalho, o que não foi questionado por nenhum autor. O maior problema é que Schmidel traduz os nomes para a sua língua, tornando-os, por vezes, irreconhecíveis.

Outra fonte usada é a carta de Anchieta, escrita em São Paulo de Piratininga, ao Padre Inácio de Loiola, em 1 de setembro de 1554. Nela encontramos a critica a uma povoação e aos seus moradores, mas sem citar nomes. Segundo ela, os moradores usavam arco como os índios e impediam a catequese:

O que não é tanto para admirar a detestável maldade dos próprios Cristãos, nos quais acham não só exemplo de vida como favor e auxílio para cometerem delitos; porquanto, uns certos cristãos, nascidos de pai português e de mãe brasílica, que estão distantes de nós nove milhas, em uma povoação de Portugueses, não cessam, juntamente com seu pai, de empregar contínuos esforços para derrubar a obra que, ajudando-nos a graça de Deus, trabalhamos por edificar, persuadindo aos próprios catecumenos com assíduos e nefandos conselhos para que se apartem de nós e só a eles, que também usam de arco e flechas como eles, creiam, e não

${ }^{171}$ Schmidel, op. cit, p. 106.

172 É interessante notar que nessa edição espanhola houve tradução do nome de Joan Reinveille para Juan Ramallo. 
dêm o menor crédito a nós, que para aqui fomos mandados por causa da nossa perversidade. Com estas e outras semelhantes fazem que uns não acreditem na pregação da palavra de Deus, e outros, que já víamos entrarem para o aprisco de Cristo, voltem aos antigos costumes, e fujam de nós para que possam mais livremente viver. Tendo os irmãos gasto um ano quase inteiro no ensino de uns certos, que distam de nós 90 milhas e tinham renunciado a costumes pagãos, estavam determinados a seguir os nossos, e haviam-nos prometido que nunca matariam aos contrários, nem usariam de carne humana em suas festas; agora, porém induzidos pelos conselhos e palavras destes Cristãos e pelo exemplo da nefanda e abominável ignomínia dalguns deles, preparam-se não só para os matar, mas também para os comer. ${ }^{173}$

Portanto, podemos concluir que a visão negativa sobre a vila de Santo André é resgatada a partir de Schmidel e dos jesuítas, o olhar do "outro" que representa São Paulo. Os próprios moradores nada deixaram por escrito de sua vivência, para se defenderem dessas críticas.

Por outro lado, para valorizarem a vila, os autores estudados no capítulo Santo André na historiografia paulista usam os trechos das atas para provarem que Santo André era "civilizada" e cristã, pois os seus moradores seguiam as normas da cidadania e os rituais cristãos.

Ao defenderem que Santo André era civilizada, argumentaram que a vila seguia as regras de cidadania, como eleições regulares, com voto aberto, respeitando também a lei e o Rei de Portugal, conforme observamos no trecho a seguir da ata de 3 de novembro de $1555^{174}$ :

\begin{abstract}
E fazedo asi a dita camara hos ditos hoficiais e mãdarão chamar ho dito povo onde cada hu deo sua voz de $\mathrm{p}^{\text {dor }}$ do cõselho e saio $\mathrm{p}^{\mathrm{r}}$ vozes na dita camara $p^{r} p^{\text {dor }}$ do cõselho por mais vozes alv ${ }^{0}$ anes $m^{\text {or }}$ nesta vila logo mãdarão chamar a dita camara ao dito alv $^{\circ}$ anes ao qual deu o dito Juiz juram ${ }^{\text {to }}$ dos samtos havãgelhos em q ele pos a mão presente mim escrivão da dita camara e prometeo de dizer e fazer verdade e seu hoficio e ho q El rei nosso sñor mãda e suas ordenacois de precurar $\mathrm{p}^{\mathrm{r}}$ ho dito cõselho e fazer ho que lhe ho dito Sr mãda [...]
\end{abstract}

Ao mesmo tempo em que seguia as regras de cidadania, era uma aldeia cristã. Para os autores do IHGSP, era importante provar a ascendência cristã dos primeiros povoadores do planalto, negando as acusações de judaísmo que

173 Ibid., p. 46.

${ }^{174}$ Atas da Câmara de Santo André da Borda do Campo (1555-1558), op. cit., p. 277. 
pudessem surgir.

No extrato abaixo da ata de 8 de fevereiro de $1557^{175}$, João Ramalho e Simão Jorge fazem um juramento sobre os Santos Evangelhos, ao assumirem os cargos de vereador e juiz ordinário, respectivamente:

Aos outo dyas do mes de fevereyro da dyta era asyna escryto se ajutarão hos ofysyaes na caza do cõselho aõde derão jurãm ${ }^{\text {to }}$ a symão Jorge e a João Ramalho a saber a João Ramalho de vereador e a symão Jorge de Juys ordenayro desta dyta vylla e llogo perãote mym lhe foy dado jurãm ${ }^{\text {to }}$ dos sãotos avãogelhos em que puzerão a mão que bem e verdadeyram ${ }^{\text {te }}$ e co são cõsyemsya facão seus ofysyos segudo o sõr $D^{s}$ lhes der a emteder e, que $p^{r}$ meterão faze verdade como dyto tenho e o asynarão todos aquy [...]

Da mesma forma que era uma vila civilizada e cristã, vimos que Santo André era vila de fronteira que controlava a circulação das pessoas que passavam pelo planalto de Piratininga em direção ao Paraguai e vice- versa, ao mesmo tempo que era um posto alfandegário, servindo, também, para abastecer o litoral.

$\mathrm{Na}$ Ata de 30 de julho de $1557^{176}$, podemos perceber que Santo André era o posto mais avançado do domínio português no planalto, quando o escrivão afirma que estavam na fronteira com os contrários. O fragmento a seguir da ata mostra essa idéia:

E lloguo na dyta camara a requerym ${ }^{\text {to }}$ do percurador do cõselho em
como a notysia lhe veo que sertos omes m. ${ }^{\text {ors }}$ desta vylla e seus
termos se querem hyr fora da dyta vylla $\mathrm{p}^{\mathrm{r}}$ hu serto ome hos cõpele
$\mathrm{p}^{\mathrm{a}}$ que vão co elle $\mathrm{p}^{\mathrm{a}}$ ho mar que elle lhe requerya que mãodasem $\mathrm{p}^{\mathrm{r}}$
pena ao syto Estevão da costa hos não cõsymtyse hyr nem lleve $\mathrm{p}^{\mathrm{a}}$
sua caza $\mathrm{p}^{\mathrm{r}}$ quãoto estamos em frõteyra dos contrayros e lloguo $\mathrm{p}^{\mathrm{r}}$
elles dytos ofysyais foy acordado de lhe mãodarem por pena ao dyto
Estevão da costa de quymze cruzados a metade $\mathrm{p}^{\mathrm{a}}$ o cõselho e a
metade $\mathrm{p}^{\mathrm{a}}$ quem ho acuzar e asym aos dytos $\mathrm{m}^{\text {ors }}\left[{ }^{[. . .]}\right.$

Ao mesmo tempo que era fronteira, a vila tinha a função de controlar a população do campo, conforme dito anteriormente. Na Ata de 10 de fevereiro de $1556^{177}$, o regimento do governador Duarte da Costa foi apresentado aos cidadãos. Esse regimento proibia os portugueses e os castelhanos de circularem entre 0 Paraguai e São Vicente. É o que observamos abaixo:

\footnotetext{
175 Ibid., p. 306.

176 Ibid., p. 312.

177 Ibid., p. 289.
} 
E logo na dita camara palo de proeça apresetou hu regim ${ }^{\text {to }}$ do sõ governador Dom Duarte da Costa do quall o trelado He o segite. Regim $^{\text {to }} \mathrm{q}$ há de ter o capitão Brás Cubas $\mathrm{p}^{\mathrm{a}}$ a femte $\mathrm{q}$ ouver demtrar pólo cãpo $\S 1 .^{\circ}$ nõ cõsemtireis $q$ nenhu portuges ne castelhano vam pelo campo $\mathrm{p}^{\mathrm{a}}$ o peraguay ne $\mathrm{p}^{\mathrm{a}}$ outra allgua povoasão dos castelhanos e se for caso q allgu castelhano venha por terá dallgua de suas povoasõis a esa capitania vos o fareis logo ebarcar no primeyiro bavio $\mathrm{p}^{\mathrm{a}}$ estas capitanias do brazill [...]

A Carta de Nóbrega ao Padre Luiz Gonçalves da Câmara de São Vicente a 15 de junho de $1553^{178}$ também cita que a rota para o Paraguai foi fechada, conforme observamos no seguinte trecho:

[...] e a principal causa de todas foi fechar-se o caminho, por razão dos castelhanos, que estão pouco mais de cem léguas desta Capitania, e dizem que na demarcação de El-rei de Portugal. E temse por certo haver muita prata na terra e tanta que dizem haver serras dela, e muita noticia de ouro, pelo qual fechou e atalhou o caminho, até Sua Alteza prover a isso [...]

Quatro anos depois, em 1557, esse caminho ainda estava fechado, segundo a Carta do Padre Luiz da Grã a Santo Inácio ${ }^{179}$ :

[...] determinou pedir licença ao Governador para irem os Irmãos tomá-las ao Paraguai, que é uma cidade de Castelhanos, pelo Rio da Prata acima, que já tem Bispo. Não Iha deu o Governador, por estar aquele caminho fechado pelo Governador passado, por seus respeitos temporais, dando-Ihe esperança que EIRei o mandaria abrir para todos.

A vila abastecia o litoral de carne, escravos e mantimentos. $\mathrm{Na}$ ata de 10 de fevereiro de $1556^{180}$, podemos observar que havia liberdade para a população de Santo André sair e "resgatar" índios, desde que houvesse um revezamento e que não fossem os mais novos:

[...] Dareis licemça aos moradores desa capitania $\mathrm{p}^{\mathrm{a}}$ ire resgatar pelo campo demtro e maneyra q o proveito seja ygual así aos pobres como aos riquos e yrão repartidos de maneira q vão hus e hu tempo

\footnotetext{
${ }^{178}$ A Carta do Padre Manuel da Nóbrega de 15 de junho de 1553 foi publicada em LEITE, S. Novas Cartas jesuíticas (de Nóbrega a Vieira), op. cit., p. 41.

${ }^{179}$ A Carta do Padre Luiz da Grã de 7 de abril de 1557 foi publicada em LEITE, id., p. 183.

${ }^{180}$ Atas da Câmara de Santo André da Borda do Campo (1555-1558), op. cit., p. 289.
} 
e despois de vydos yrão outros sem q yrão homes de recado e pesoas q saibam a limgoa que tratem bem os gemtios e não dane o trato aos christãos e ss limgoas que fore co os que fore resgatar sejão homes e não - mosos por q som emformado $q m^{\text {tas }}$ vezes vão por limgoas mosos day da terá o q hé muyto prejuizo dos moradores da dita capitanya $[\ldots]$

O Padre Manuel da Nóbrega também confirma que a função de Santo André era abastecer o litoral com mantimentos, é o que se pode observar no fragmento abaixo da Carta que escreveu da Baía, ao Padre Miguel de Torres, provincial de Portugal, em 2 de setembro de $1557^{181}$ :

[...] Os do mar vivem em mais trabalho, porque, posto que tenham peixe em abastança não têm terras para mantimentos, nem para criações e sobretuto vivem em grande desassossego, porque são cada dia perseguidos dos contrários e o mantimento que comem vem do Campo, dez ou doze léguas de caminho o mais mau que se pode imaginar [...]

Além do apresamento indígena, a população de Santo André também sobrevivia da, conforme verificamos no trecho abaixo, da ata de 22 de janeiro de $1556^{182}$, em que os moradores procuram definir o preço da farinha que plantam:

[...] e estamdo asi todos jumtos em camara lhes pareseo a todos bem $q$ posesem a medida do allqueire da farinha a seis vimteis o allqueire $p^{r}$ quãto a dita medida era muito grade e se aqueixava todos esse povo de tamanha medida e tam pouco preso como era hu tostao e asi o dito precurador do cõselho em nome de too mais povo requereo a eles ditos oficiais q a tanto valese so pena de dous tostões [...]

Ainda nesse mesmo dia, o morador Gracia Roiz solicita ao Concelho mais terras para aumentar os seus currais, provando mais uma atividade econômica dos moradores da vila. É o que aparece no trecho a seguir:

[...] Gracia Roiz $\mathrm{m}^{\text {or }}$ nesta vila de samtãdré faz a saber a a VS. MS. E como ele mnesesidade de hu chão q esta abaixo de seu quintal q podia ter obra de vite brasas quãto diz o seu quitall $p^{a}$ bayxo dos quitais $\mathrm{p}^{\mathrm{a}} \mathrm{o}$ campo o qual lha pede $\mathrm{p}^{\mathrm{a}}$ seus curais de seu gado $[\ldots]^{183}$

A preocupação com a defesa da vila foi constante em Santo André,

\footnotetext{
${ }^{181}$ LEITE, S. Novas Cartas Jesuíticas. op. cit., p. 71.

182 Ibid., p. 284.

183 Ibid.; p. 286/287.
} 
durante a sua curta existência, tanto que em vários momentos, as Atas citam a necessidade de arrumar a cerca, como na ata de 25 de janeiro de $1556^{184}$.

\begin{abstract}
Em os vyte e cyquo dias do mês de Janeiro de Mill e quinhetos e cyquoeta e seis em esta vila de samto amdré da borda do campo forão jutos os ofisiaes da camara desta dita vila a requerim ${ }^{\text {to }}$ do precurador do cõselho o qual dise ter cousas $q$ requerer $p^{a}$ bem do povo $E$ logo na dita camara o dito precurador requereo aos ditos ofisiaes q co hua certa pena mãdase cubrir a cerqua q em allguns lugares estava $p^{a}$ cair o $q$ logo pelos ditos ofisiais foy mãdado $q$ por quãto Fransisquo enes e gerallde enes e amdré fiz tinhão aqui rosas e se logravão da tera como moradores e não tinhão até aqui cuberto nenhua cerqua os ditos ofisiais ouverão por bemque os sobreditos demtro e por toda esta somana q vem cubrisem a cerqua q está por cubrir cõvemm a saber: da casa dele afonso enes até o baluarte a quall cubrirão no dito tempo so pena de douus tostões ametade $\mathrm{p}^{\mathrm{a}} \mathrm{o}$ cõselho e a outra metade para que nos acusar [...]
\end{abstract}

Ainda em setembro desse mesmo ano, podemos verificar que a Câmara decidiu que os moradores que tivessem casas nas cercas e não as arrumassem em 20 dias, seriam multados:

E llogo na dyta camara a requerym ${ }^{\text {to }}$ do percurador do cõselho acordarão todos jutos que aquelles que tiverão e tem porta da serca a cubra demtro em vyte dyas o q não a cobryr paguará hu tostão a metade $p^{a}$ o cõselho e a metade $p^{a}$ quem ho acuzar $p^{r}$ cada vez $q$ se achar descuberta $[\ldots]^{185}$

Três meses depois, em 14 de dezembro de $1556^{186}$, a ata reafirma o pedido para os moradores arrumarem a cerca:

Aos quatorze dyas do mês de dezebro da era de myll e quynhemtos e syncoeta e seys anos em esta vylla de sãoto ãdre se ajutarão hos ofysyaes em a caza do cõselho $p^{a}$ fazerem camara na quall camara acordadão hos ofysyaes q cubrysem as sercas so pena da pena que estava posta e que fyzesem hos caminhos como dyto [...]

A preocupação com a defesa diante dos ataques de inimigos foi constante.

Para proteger a vila, além das cercas, há a preocupação em controlar a saída das

\footnotetext{
${ }^{184}$ Ibid., p. $287 / 288$.

185 Ibid., p. 299.

${ }^{186}$ Ibid., p. 302.
} 
pessoas para não haver o esvaziamento da vila, conforme aparece na ata de 22 de maio de $1557^{187}$ que aponta a necessidade de um porteiro para garantir o controle do fluxo de pessoas na vila: "E lloguo na dyta camara que asym fyzerão acordarão de fazer hu allcayde e porteyro $\mathrm{p}^{\mathrm{r}}$ vertude de hu apomtam. ${ }^{\text {to }}[\ldots]$..

Também na ata de 21 de agosto de $1557^{188}$ aparece a necessidade de haver um revezamento na vila: metade da população sai num dia e a outra metade no outro, para que a vila não ficasse desprotegida. É o que podemos verificar no trecho a seguir:

Aos vymte e hu do mês dagosto da dyta era em esta vylla de sãoto ãodré da borda do cãopo em ho paço do cõselho se ajutarão hos ofysyais $p^{a}$ fazerem camara e couzas que cõpre a bem do povo a requerym ${ }^{\text {to }}$ do percurador do cõselho a bem do povo a requerym ${ }^{\text {to }}$ do percurador do dyto cõselho e lloguo na dyta camara requereu ho percurador do cõselho aos dytos ofysyais $p^{r}$ quãoto se hyão todos a suas roças e fycava esta vylla sem jemte que se repartisem a metade hu dya e outra metade outro dya de maneyra que não fique a vylla sem jemte so pena de ho que ho cõtrayro fizer pagará s eto e symcoemta rs. $\mathrm{P}^{r}$ quada vez que for co achado e de como asym ho mãodarão ho asynarão aquy [...]

No ano seguinte, em 31 de maio de $1558^{189}$, as discussões na Câmara são referentes as informações de que os índios estão chegando. Diante desse perigo, todos os moradores deveriam reparar os muros e tinham oito dias para fazerem isso. Havia também a necessidade de se fazerem novas guaritas. É o que aparece no trecho abaixo da ata desse dia:

[...] e o dyto $p .^{\text {dor }}$ do cõselho em nome de todo ho povo requereo aos hos ofysyaes q hera servyço de Deus e ell Rey nosso sõr e proll do povo e be da vylla $p^{r}$ quãoto tynhãomos nova $q$ nobos hymdyos vynhão escõtra nos que se repayrasem hos muros e fazere se allguas guarytas $p^{a}$ nosa defemção $p^{r}$ ser nesesaryo a bem do povo como dyto era e hos dytos ofysyaes co ho dyto povo abaixo asynado acordarão e determinarão que hera muy bem e nesesayros novas sercas e fyzesem garytas asym e da maneyra como pollo dyto $\mathrm{p}^{\text {dor }}$ foy requerydo ho que todos se obrygarão douje a outo dyas prymeyros seguintes a dare todas as obras feytas e não llevare mão dellas ate não ser acabada emtemder-se que ajudarão todos hus aos outros e repayrarão as portas e hera nesesaryo a nosa defemção que todos asynarão de asym cõpryr co hos dytos ofysiaes [...]

\footnotetext{
187 Ibid., p. 308.

188 Ibid., p. 313.

189 Ibid., p. 320.
} 
A partir daí, não podemos mais usar as atas para saber o que aconteceu, pois as próximas que encontramos são as da vila de São Paulo, datadas de 1562 , quando a vila de Santo André já mudara de sede e o perigo dos ataques dos tamoios estava cada vez maior.

Através das atas da vila de Santo André, podemos perceber um pouco da vida dos moradores pela voz dos seus próprios cidadãos. Porém, como os pesquisadores do IHGSP ao estudarem Santo André, sempre tiveram um ponto de vista pré-definido ao consultarem as fontes e nem sempre conseguiram perceber esse mundo, ficando restritos ao olhar que os viajantes, cronistas e jesuítas tinham sobre a vila.

\subsection{Mudança de sede de vila para a casa dos jesuítas}

$\mathrm{Na}$ tentativa de explicar os motivos que teriam levado à mudança da sede de vila, os autores basearam-se nas atas da Câmara da Vila de Santo André e também nas cartas jesuíticas, procurando provar que em Santo André as pessoas passavam fome, que era uma vila desprotegida, em que o gado morria e que não tinha pároco.

Ao citarem essas fontes, esses autores procuravam provar que a mudança ocorreu a pedido dos próprios moradores, porém, com grande influência dos jesuítas.

Os trechos mais usados são das atas da vila de Santo André entre 1557 e 1558; a carta de Nóbrega de setembro de 1557 de São Vicente para o padre Miguel de Torres de Lisboa; as cartas de José de Anchieta de 30 de julho de 1561 ao Padre Laynes e a de 12 de junho de 1561; a carta da Câmara da vila de São Paulo à Rainha D. Catarina, de 20 de maio de 1561 e a ata da Câmara da vila de São Paulo de 12 de maio de 1564.

Na carta do Padre Manuel da Nóbrega de 2 de setembro de 1557 da Baía, ao Padre Miguel de Tôrres, de Lisboa ${ }^{190}$, o Padre Manuel da Nóbrega pede a união das

${ }^{190}$ LEITE, S. Novas Cartas jesuíticas, op. cit., p. 71. 
duas povoações, pois havia carência de alimentos em Santo André. Segundo as suas próprias palavras:

[...] e creio que, se alguma coisa pode fazer que os moradores não despovoem aquela Capitania, será estar ali aquela casa. Também me parece que se devia dizer a Martim Afonso e a Sua Alteza que, se quer que aquela Capitania se não despovoe de todo, que deem liberdade aos homens para que os do Campo se ajuntem todos juntos, no Rio de Piratininga, onde êles escolherem, e os do mar se juntem também todos juntos onde melhor for, por estarem mais fortes, porque a causa de despovoarem, é fazerem-nos viver na Vila de Santo André à Borda do Campo, onde não tem mais que farinha e não se podem ajudar do peixe do rio, porque está três léguas daí, nem vivem em parte conveniente para suas criações; e, se os deixassem chegar ao rio, teriam tudo e sossegariam [...]. Se nisto se não provê com brevidade a mim me parece que aquela Capitania se perderá, e, porque destas coisas devem ser melhor informados pela via de S. Vicente, cesso.

Nessa carta, Santo André é citada como sendo causa do despovoamento do planalto e é interessante notar que Nóbrega não solicita para ir especialmente a São Paulo, mas para algum trecho próximo ao rio Piratininga, "onde elles escolherem".

Nesse mesmo ano, também encontramos na ata da Câmara de Santo André de 20 de setembro de $1557^{191}$, o pedido dos moradores para a mudarem para perto de algum rio. Esse trecho também não prova que almejavam ir para as proximidades da casa dos jesuítas, conforme o fragmento:

Aos vymte dyas do mês de setembro da dyta era asyma escryto em esta vylla de sãoto ãodré em há caza do coselho se ajutarão hos ofysyais da camara $\mathrm{p}^{\text {a }}$ fazer camara a requerym ${ }^{\text {to }}$ do percurador do cõselho e lloguo na dyta camara requereo o percurador do cõselho aos ofysyais em nome do povo como estavão em esta dyta vylla e moryão de fome e paçavão muyto mall e morryão ho guado e que se fosem detro no termo della de llõgo dallgu ryo ...... e llogo na dyta camara requereo e dyse que não cõsemtya em tall mas amtes se nyso se recresesem alguas mortes hou perdas de fazeda de aver o dyto povo dar cota a que de dyreito fose [...]

Provavelmente estavam passando por algum período de carência e queriam ir para uma região mais favorável. Esse pedido complementa o pedido dos jesuítas

191 Atas da Câmara de Santo André da Borda do Campo (1555-1558), op. cit., p. 313. 
exposto acima. Porém o governo não atendeu aos pedidos, pois Santo André ainda era a porta de entrada para o sertão, controlando a rota para o Paraguai e o governo português não queria mudar esse lugar.

Dois anos depois, a justificativa para a mudança não é mais a carência de alimentos, mas sim a defesa, tanto que isso aparece na ata da Câmara da Vila de São Paulo ${ }^{192}$, que cita a extinção de Santo André e a fundação de São Paulo, que teria ocorrido em 1560, para fortalecer a vila e por vontade dos próprios moradores e também dos jesuítas:

[...] assim pelas rezois asima ditas e por as rendas $q$ os ofisiais da dita vila resebem $p^{s} q$ agora fez quatro anos $q$ a esta quapitania veo ho $G^{\text {dor }}$ Me de Sá, $p^{r}$ Ihe ser requerido $p^{r}$ o povo de São Visente, Sãotos e psadres da cõpanhia de q as provese e fortalezase esta vila pelas rezões asima ditas hás quais vistas por ele o fez cõ despovoamento da vila de sãoto ãdre e hos moradores dela recolher e fazer viver nesta dita villa

Os historiadores também usam a carta que Jorge Moreira, Joannes Alves e Antônio Cubas, oficiais da Câmara de S. Paulo, dirigiram à rainha D. Catarina, em 20 de Maio de $1561^{193}$, para confirmarem que os moradores de Santo André também queriam a mudança e que havia mais segurança nas proximidades da casa dos jesuítas:

\begin{abstract}
Este ano de 1560 veio a esta Capitania Mem de Sá, governador geral e [...] mandou que a vila de Santo André, em que antes estávamos, se passasse para junto da casa de São Paulo, que é dos Padres de Jesus, porque nós todos Iho pedimos por uma petição, assim por ser o lugar mais forte e mais defensável, assim dos contrários como dos nossos índios, como por muitas outras causas, que a ele e a nós moveram.
\end{abstract}

O Padre Anchieta na obra Informação do Brasil e de suas capitanias ${ }^{194}$, cita que as duas são a mesma vila e que a mudança ocorreu em 1560 por motivos religiosos, em outras palavras, a falta de pároco:

${ }^{192}$ Actas da Camara da Villa de São Paulo - 1562-1596. Volume I, século XVI. Publicação official do Archivo Municipal de São Paulo. São Paulo: Duprat\&C, 1914, p.12.

${ }^{193}$ História Geral do Brasil, São Paulo, $4^{a}$ ed., I, São Paulo, n. 48 do III vol. Das Cartas, p. 400/401.

194 ANCHIETA, J. de. Informação do Brasil e de suas capitanias [1584]. São Paulo: Obelisco, 1964 (Cadernos de História, 3). 
Esta vila antigamente era da invocação de Santo André e estava três léguas mais para o mar, na borda e estrada do Campo, e no ano de 1560 por mandado do governo de Mem de Sá se mudou a Piratininga, porque não tinham cura e somente dos Padres da Companhia era visitada e sacramentada, assim os portugueses como os índios seus escravos, como nem ainda têm outro cura senão os da Companhia que Ihes ministram todos os sacramentos por caridade $[\ldots]$

O Padre José de Anchieta também reafirma a mudança feita a pedido dos padres em 12 de junho de 1561, na carta escrita de São Vicente ao Padre Geral Diogo Laynes ${ }^{195}$, acrescentando a necessidade de defesa:

\begin{abstract}
Além desta uma povoação de portugueses, que estavam três legoas apartados, se mudou para Piratininga por mandado do governador, a instâncias dos Padres, porque estava em mui grande perigo dos inimigos corporais, dos quais estava já espiada, por caminhos que haviam aberto pelos bosques, donde sua terra temia-se cada dia a vir a destruir, ou ao menos saltear e matar alguns deles, ou seus escravos, como costumavam, e muito mais pelo grandíssimo perigo em que estavam dos inimigos espirituais, pelos quais não só espiada, mas salteada e roubada estava muitas vezes, porque não tinham sacerdote que lhes administrassem os sacramentos, e ainda que em suas enfermidades os socorríamos, e de noite por silvas muito espantosas; todavia sempre o diabo levava muitos dos seus escravos, aos quais muitas vezesnão se podia remediar, que primeiro não morressem. Por estas causas trabalharam muito os Padres que se passassem para Piratininga, onde agora estão muitos deles, quase sujeitos à vontade e disposição dos Padres, no que toca às suas almas [...]
\end{abstract}

É interessante notar que as fontes de 1557 e 1558 citam a carência de alimentos, porém, mesmo com os moradores pedindo a mudança, ela não ocorreu. Nessas fontes não apareceu em nenhum momento, o nome do colégio para, nas suas proximidades, localizar-se a nova sede. Os moradores pedem apenas para que seja em outro local, com maiores facilidades econômicas. Porém, os historiadores, na construção das suas argumentações dos fatores que teriam trazido a necessidade de mudança de sede, deduzem que, nessa época, já existia a vontade de se mudarem para as proximidades da casa dos jesuítas.

É o que podemos observar na carta de São Vicente, que o padre José de

195 Cartas, Informações, fragmentos históricos e sermões do Padre Joseph de Anchieta, S. J. (1554-1594). Op. cit., p. 170-171. 
Anchieta enviou ao padre geral Diogo Lainez em 16 de abril de $1563^{196}$ :

Esta guerra foi causa de muito bem para os nosso antigos discípulos, os quais são agora forçados pela necessidade a deixar todas as suas habitações em que se haviam esparzido, e recolherem-se todos a Piratininga, que eles mesmos cercaram agora de novo com os Portugueses [...]

A Carta de 1 de junho de 1560 de Anchieta ao Padre Geral ${ }^{197}$, além de colocar que a mudança já ocorrera, pois cita "aqui junto da vila", coloca o perigo dos ataques dos índios do sertão, contra os quais vivem em constante guerra:

Quanto aos Índios do sertão, muitas vezes estamos em guerra com eles, e suas ameaças sempre padecemos: matáram ha poucos dias a alguns Portugueses que vinham do Paraguai ficando ensorbebecidos com esta maldade, ameaçando-nos com a morte. Tambem os inimigos com contínuos assaltos que dão nos lugares, destroem os mantimentos, e levam a muitos cativos. No ano passado deram em uma casa aqui junto da Vila, e cativaram muitas mulheres que tinham saído de casa, e iam fugindo: embarcando-se nas canôas as leváram [...]

Porém, foi a necessidade de defesa da posse portuguesa no planalto que levou à mudança. As fontes do período de 1560 colocam essa questão de forma bastante nítida, construindo a argumentação de quais teriam sido as causas da mudança para as proximidades do colégio.

Os jesuítas, como não poderia deixar de ser, valorizaram o lado religioso, argumentando que a falta de pároco teria levado à mudança, como se isso bastasse para o governo português realizá-la.

\subsection{João Ramalho}

As referências a João Ramalho aparecem diluídas nas informações sobre a vila que estão nas atas, no seu testamento, nas cartas jesuíticas e no relato de Schmidel.

196 Cartas, Informações, fragmentos históricos e sermões do Padre Joseph de Anchieta, S. J. (1554-1594). Op. cit., p. 186.

197 Ibid., p. 156. 
Para definir o seu caráter, as principais fontes usadas pelos autores paulistas, são as cartas jesuíticas e a obra de Schmidel. Porém, quando querem provar a sua importância e prestígio no planalto usam as atas de Santo André bem como as de São Paulo.

É interessante notar que até Schmidel é usado para provar a sua influência e prestígio, mesmo com a visão negativa que ele tem a respeito de Ramalho, mostrando que ele era um líder poderoso: "[...] este Ramallo puede reunir em un sólo dia cinco mil índios, em tanto que el rey sólo junta dos mil [...]."198

Por meio desse fragmento, os autores deduzem que ele era o grande chefe do planalto, por comandar aproximadamente 800 cristãos: "[...] Los índios, entre los cuales viven ochocientos cristianos em dos lugares, están sujetos AL Rey de Portugal y em poder Del dicho Juan Ramallo [...]". 199

Por sua vez, a base das criticas que recebe vem da carta que Diogo Jácome escreveu de São Vicente, em junho de 1551, aos Padres de Coimbra ${ }^{200}$. Porém, nessa carta não aparece nem o nome de João Ramalho nem o de Santo André, conforme podemos perceber no trecho a seguir, que é o mais usado pelos autores:

[...] Outros há tão apartados ou mais, pois que são obstinados em este negro peccado, com os quaes trabalha de dia pólos apartar e de noite em como os há de apartar de sua má obstinação em que estão com Indias da terra e tal há que lhe seria melhor um braço cortado que fallar o que falla contra o Padre que com todo amor o reprehende e exhorta com todos os meios que póde e pera isso busca e são que há hi tal que sobre ir d'aqui a 10 leguas sobre uma pessoa que haverá 20 ou 30 annos que está en peccado mortal, sobre com todos os mimos com que primeiro o trouxe, e vendo sua obstinação sobre estar excomunguado pollo Viguairo da terra, quis o nosso Padre ir lá a dizer missa, porque se passa hum anno e dous que não vêem a Deus, nem n'o vem a ver, podendo vir; e, estando lá dizendo missa, entrou este homem, de maneira que the mandou o Padre dizer que se sahisse, que não podia celebrar com elle e sahindo, sahiram também dous filhos seus da terra com elle de maneira que se determinaram pera, como acabasse a missa, de the darem na cabeça, o qual acabando a missa se sahio e veio pera elle, o qual the rogou que não tivesse conta com elle, que era melhor christão que elle e que fazia muito boas obras, mas não dizia si estava apartado do peccado, para the aproveitarem e assim tiveram mão nelle e depois vieram os filhos com suas armas que são uns homens como salvagens contra o nosso mesmo Padre e elle

${ }^{198}$ Schmidel, op. cit., p. 106.

199 Ibid., p. 106.

200 Cartas Avulsas - Cartas jesuíticas II (1550-1568). Rio de Janeiro: Officina Industrial Graphica, 1931, p. 104. 
assentado de joelho diante d'elles apparelhado a receber o que viesse, de maneira que não faltou aqui senão Nosso Senhor alargar sua mão pera o Demonio obrar suas más obras [...]

A carta escrita pelo Irmão Pero Correia ao Padre Belchior Nunes Barreto, de São Vicente, em 20 de junho de $1551^{201}$ descreve problemas entre jesuítas e portugueses sem citar nomes:

[...] muitas das mulheres de Portugal que cá há, e uma destas se achou umas 10 leguas daqui, onde quizeram tratarmal o nosso Padre e o ameaçaram com um pau, e o ameaçador foi um homem que ha 40 annos que está nesta terra e tem já bisnetos e sempre viveu em peccado mortal e anda excommungado, e o Padre não quiz dizer missa com elle, e daqui veiu, depois da missa acabada, a querel-o maltratar, porque elle é possante; mas a India alli preguou muito rijo e com grande fé, offerecendo-sse a padecer de companhia com o Padre se comprise.

O nome de João Ramalho aparece em 1553, quando Manoel da Nóbrega, ao chegar a São Vicente, em viagem com Tomé de Souza, recebe más informações a respeito de João Ramalho, e, em carta de 15 de junho desse ano ${ }^{202}$, as transmitia ao padre Luís Gonçalves da Câmara, em Portugal, escrevendo:

Nesta terra está um João Ramalho. É muito antigo nela e toda a sua vida e a dos seus filhos é conforme à dos Índios e é uma petra scandali para nós, porque a sua vida é principal estorvo para com a gentilidade que temos, por ele ser muito conhecido e muito aparentado com os índios. Têm muitas mulheres. Êle e seus filhos andam com irmãs e têm filhos delas, tanto o pai como os filhos. Vão à guerra com os índios e as suas festas são de índios e assim vivem andando nus como os mesmos índios. Por todas as maneiras o temos provado e nada aproveita, até que o deixamos de todo. Este estando excomungado, por não se confessar, e não querendo os nossos padres celebrar com ele, disse que também os Padres e Irmãos pecavam com as índias [...].

Ao subir a serra e chegar ao planalto, cerca de dois meses depois, após encontrar João Ramalho e com ele tratar, a linguagem do Padre Manoel da Nóbrega fica diferente, como se pode ler na carta que a 31 de agosto de $1553^{203}$ escreveu ao mesmo padre Luís Gonçalves da Câmara:

\footnotetext{
${ }^{201}$ Ibid., p. 92.

${ }^{202}$ LEITE, S. Novas Cartas jesuíticas, op. cit., p. 46.

${ }^{203}$ Ibid., p. 52.
} 
Nesse campo está um João Ramalho, o mais antigo homem que está nesta terra. Tem muitos filhos e mui aparentados em todo êste sertão. E o mais velho dêles levo agora comigo ao sertão por mais autorizar o nosso ministério. João Ramalho é muito conhecido e venerado entre os gentios e tem filhas casadas com os principais homens desta Capitania e todos estes filhos e filhas são de uma índia, filha dos maiores e mais principais desta terra. De maneira que, nele e nela e em seus filhos, esperamos ter grande meio para a conversão destes gentios. Êste homem, para mais ajuda, é parente do Padre Paiva e cá se conheceram [...].

Nessa argumentação, o que é mais provável que tenha acontecido é que Nóbrega, por querer criar a casa de catequese no planalto, na jurisdição de Santo André, preferiu não entrar em atrito com João Ramalho. Mesmo assim, a partir de 1554, com a instalação dos jesuítas no planalto, começaram os conflitos entre eles e João Ramalho, na disputa pela mão- de- obra indígena.

A Carta do padre Balthasar Fernandes, de São Vicente de $1568^{204}$ também cita um homem branco e não especifica que seja João Ramalho, mas é usada como uma referência negativa:

Um homem branco, que há 60 annos que está nesta terra entre este
gentio, que agora é quasi de cem anos, estando entre os índios e
vivendo não sei de que maneira, e não querendo nada de nossas
ajudas nem ministério, deu-lhe Deus de rosto com um accidente,
além de muitos corrimentos e pontadas que tinha. Veiu então um
filho seu que pousava daqui uma légua a dizer-nos que seu pai
morrera; e suspeitando nós que não seria ainda morto, foram dous
Padres cedo a correr por aguas que estavam polo campo por onde
haviam de passar, por ser grande cheia. Chegados à casa do
miserável velho, que não queria nada de deus, veio Deus a visitar
com os nossos, porque o que estava dantes já morrendo, em mau
estado, acudiu-lhe Deus com a confissão que elle fez bôa, pondo-se
em bom estado e commungando; mas não morreu daquelle
accidente, sinão anda para isso apparelhado e posto na verdade,
esperando por sua hora que cedo lhe virá.

Nóbrega, por sua vez, tentou anular o casamento de João Ramalho em Portugal. Diante dessa situação, os autores estudados colocaram que as relações entre eles eram boas. É o que percebemos no trecho a seguir, da carta de Manuel da Nóbrega ao Padre Luiz Gonçalves da Câmara de 31 de agosto de $1553^{205}$ :

\footnotetext{
${ }^{204}$ Cartas Avulsas - Cartas jesuíticas II (1550-1568). Op. cit., p. 501.

${ }^{205}$ LEITE, S. Novas Cartas jesuíticas, op. cit., p. 52/53.
} 
[...] Quando veio da terra, que haverá 40 anos e mais, deixou a sua mulher lá, viva, e nunca mais soube dela, mas que the parece que deve ser morta, pois já vão tantos anos. Deseja muito casar-se com a mãi destes seus filhos. Já para lá se escreveu e nunca veio resposta deste negócio. Portanto é necessário que $V .{ }^{a} R^{a}$, envie logo a Vouzela, terra do P. Mestre Simão, e da parte de Nosso Senhor Iho requeiro: porque se êste homem estiver em estado de graça, fará Nosso Senhor por êle muito nesta terra. Pois estando ele em pecado mortal, por sua causa e sustentou até agora [...] Se o Núncio tiver poder hajam dele dispensa particular para este mesmo João Ramalho poder casar, não obstante que houvesse conhecido outra sua irmã e quaisquer outras parentes dela. E assim para outros dois ou três mestiços, que querem casar com índias de quem têm filhos, não obstante qualquer afinidade que entre eles haja [...]

Assim, pode-se concluir que os autores usaram as atas para valorizar a importância de João Ramalho como chefe militar e o líder do planalto. E usaram as cartas jesuíticas para desvalorizá-lo e, nelas nem sempre há uma referência específica ao seu nome.

Schmidel foi usado tanto para garantir o prestígio de João Ramalho quanto para torná-lo um selvagem, desqualificando, também, a sua vila.

As cartas jesuíticas são usadas para provar que havia oposição entre Ramalho e os jesuítas. O que nem sempre teria ocorrido, conforme observamos na Carta de Nóbrega de 1553. 


\title{
CONSIDERAÇÕES FINAIS
}

No século XX, a história da vila e da cidade de Santo André foi construída pelos "homens bons", os de "sangue limpo", que não exerciam ofícios mecânicos. Foram eles que definiram os lugares de cada um e a imagem a ser construída da cidade.

Segundo José de Souza Martins, os autores que criaram a história local, não a definiram apenas como o reflexo da História do país, embora haja uma forte relação entre essa história local e a história nacional, pois é na história local que estão as circunstâncias da história. Para ele,

\begin{abstract}
A história local não é necessariamente o espelho da História de um país e de uma sociedade. A história local não é nem pode ser uma história-reflexo, porque se o fosse negaria a mediação em que se constitui a particularidade dos processos locais e imediatos e que não se repetem, nem podem se repetir, nos processos mais amplos, que com mais facilidade poderíamos definir como propriamente históricos [...]. ${ }^{206}$
\end{abstract}

Nesse sentido, a história local procura achar o monumental no cotidiano, os seus heróis, os primeiros, a origem, os fundadores, o que permite classificá-la como uma história conservadora.

Segundo José de Souza Martins:

A população local se defende contra esse vazio de sentido, essa marginalidade histórica. Os esforços de seus historiadores e cronistas são no sentido de dar aos pequenos atos de todos os dias e às biografias esvaídas (e construídas) no trabalho duro de muitas décadas o sentido do épico, do ato monumental dos heróis civilizadores, dos grandes acontecimentos que selam o destino das sociedades. Cada um tenta encontrar no seu pequeno universo os indícios da grandiosidade que deveria estar em toda a parte, em toda história. E que seria, também, para o senso comum, critério para definir o que é História e o que não é. A História aí aparece deformadamente como a história dos 'primeiros' [...]. ${ }^{207}$

\footnotetext{
${ }^{206}$ MARTINS, José de Souza. Subúrbio: vida cotidiana e história no subúrbio da cidade de São Paulo: São Caetano, do fim do Império ao fim da república Velha. São Paulo: Hucitec / São Caetano do Sul: Prefeitura de SCS, 1992, p. 12.

207 Ibid., p. 14.
} 
A partir desse ponto de vista podemos entender como o discurso da elite local andreense uni-se ao dos intelectuais do IHGSP da cidade de São Paulo na busca das suas origens: o objetivo era o de atribuir um papel grandioso à cidade em origem. Dessa forma, a origem recente da cidade deveria ser esquecida e substituída por uma nova versão sobre a origem, localizada em um passado remoto, o século XVI. A escolha dessa data coincide com a mais antiga referência sobre a ocupação portuguesa no planalto com o povoado, e depois vila em 1553, de Santo André da Borda do Campo. Esta é a razão para substituir-se o nome do município de São Bernardo pelo de Santo André em 1938, juntamente com a mudança de sede do município. Essa mudança, também foi estratégica, pois valorizou o distrito que havia sido fundado recentemente e, portanto as posses dos Fláquer, principais responsáveis pela mudança.

A partir do momento em que se associa a vila do século XVI com a cidade do século XX, a cidade passa a ser a mais antiga da Grande São Paulo, substituindo a própria cidade de São Paulo. Dessa forma, João Ramalho e os moradores da vila recebem o papel de primeiros povoadores do planalto. Fica, assim, estabelecida a importância da cidade: a responsável pela origem da Nação.

Além ter sido responsável pela origem da Nação no século XVI, o atual município responde pela origem da industrialização do país. Dessa forma, Santo André é o ponto de partida do desenvolvimento econômico da Nação e é a cidade que mais cresce, destronando São Paulo.

O principal historiador que elaborou essa versão da história para a cidade foi Octaviano Gaiarsa que, por ter relações com o IHGSP acabou se influenciando pela sua historiografia e pelas discussões feitas sobre João Ramalho e Santo André, nessa instituição. Porém, acabou criando a sua própria versão.

Os motivos que levaram os autores estudados nessa dissertação a estudarem João Ramalho e Santo André foi o fato de Santo André ter sido uma vila transferida. Na história, há uma continuidade entre as duas vilas, pois os moradores se mudaram de uma sede para a outra por motivos de segurança diante dos ataques indígenas.

Porém, os autores paulistas do IHGSP buscaram explicar essa mudança de outras maneiras e construíram versões em que pesou uma visão dualista da História: a mudança representou o resultado de uma disputa entre o bem e o mal, o moderno e o arcaico, a civilização e a barbárie, com a vitória da civilização. 
Em tal concepção, coube a Santo André o papel negativo, o que justifica a mudança de sede.

Assim, é justamente na busca das origens da vila de São Paulo, elaborada principalmente pelo IHGSP e que ocorreu no calor da propaganda republicana no início do século $X X$, que encontramos os historiadores paulistas preocupados com a origem da vila de Santo André da Borda do Campo e com João Ramalho.

Verificamos que os discursos historiográficos foram bastante discutidos, antes de ocorrer a cristalização de uma versão sobre a memória de Santo André e João Ramalho na historiografia paulista, o que não ocorreu em Santo André, pois Gaiarsa construiu a sua versão da história da cidade praticamente sozinho.

Muitas vezes, as divergências entre os historiadores do IHGSP são apenas aparentes, pois no fundo, representam os interesses de uma mesma elite conservadora, que usa o discurso historiográfico para se legitimar no poder. A partir de tal ponto de vista, as diferentes versões sobre as origens da vila são apenas superficiais.

Observamos também que as primeiras discussões dos historiadores do IHGSP tinham duplo papel: estabelecer as origens das duas cidades e definir quem era João Ramalho, porém sem fugir da mesma linha ideológica elitista, usando as mesmas referências - as obras de Frei Gaspar da Madre de Deus e Pedro Taques.

Porém, esses autores foram diversificando suas fontes, pois tinham também como fonte de pesquisa os documentos civis impressos a partir das traduções e impressões feitas na prefeitura de Washington Luís em 1914.

Posteriormente, a historiografia dependente das obras de Taunay, procurou vincular João Ramalho aos bandeirantes, transformando-o no grande patriarca dos "calções de couro".

Por outro lado, é interessante notar como a historiografia de Santo André aliou-se ao discurso historiográfico de São Paulo com Octaviano Gaiarsa, que procurou engrandecer a cidade, reconstruindo um passado através do bandeirante, do café e da industrialização, "inventando a tradição" e preenchendo o "buraco" temporal entre 1560, data da transferência da sede da vila para São Paulo, ao século XIX, através da argumentação que a cidade "hibernara" ou "adormecera".

Porém, foi só na historiografia andreense, a partir de 1991, com o início da prefeitura de Celso Daniel, que houve a preocupação em construir uma nova versão 
para a história da cidade, mas que na prática, pouco conseguiu fugir da versão da história construída anteriormente.

Assim, pode-se concluir que, na historiografia da cidade de Santo André, há dois momentos historiográficos distintos, o primeiro, construído nas décadas de 1950 e 1960, com Gaiarsa, que se apropriou de boa parte do discurso de Taunay e do IHGSP, forjando uma memória para a cidade, que construiu monumentos e o museu; elaborou o hino, a bandeira e a história oficial e o segundo, criado a partir de 1991, que, a princípio ainda aparece vinculado com Gaiarsa e que procura dar uma esperança para a cidade (o amanhã), em que seria a que mais cresceria, a partir do momento em que um novo grupo estava assumindo o poder, o de esquerda com a prefeitura do PT, na década de 1990.

$E$ esse novo discurso foi sendo modificado no final do século $X X$, conforme percebemos, primeiro no site e, depois, no curso para os professores das redes estaduais e municipais de ensino da cidade, que acrescentou novos grupos sociais, resgatou a migração e o movimento operário na história da cidade e propôs mudanças no que seria a origem da cidade, porém sem romper com a visão do crescimento continuo e acelerado. Contudo, a memória social cristalizada predomina até nossos dias, na data do aniversário da cidade e no hino, que continuaram sendo os mesmos. Nos monumentos e nas homenagens aos heróis fundadores- Bartira, João Ramalho e Tibiriçá, que aparecem em nomes ruas, hospitais, estádios etc.

O brasão e a bandeira receberam modificações em 1972, porém o lema continuou sendo o mesmo "PAVLISTARVM TERRA MATER", rememorando às origens no século XVI.

Dessa forma, é interessante notar a persistência de uma memória social que foi construída a partir da década de 1940 e pouco se modificou no século XX, mesmo ocorrendo grandes transformações na cidade, que deixou de ser industrial e passou para a área de serviços e com a migração substituindo a imigração.

Mesmo com alguns questionamentos sobre se a origem da cidade estaria mesmo no século XVI, que acabou refletindo na historiografia, sua memória social continua sendo a mesma. Não há dois momentos nessa memória.

A cidade passa a ter uma nova função econômica, os prédios industriais viraram shoppings centers ou supermercados. Porém, sua população mantém as mesmas atitudes perante o passado, como se houvesse homogeneidade e continuidade temporal. 


\section{REFERÊNCIAS BIBLIOGRÁFICAS}

\section{FONTES}

Actas da Camara da Villa de São Paulo - 1562-1596. Volume I, século XVI. Publicação official do Archivo Municipal de São Paulo. São Paulo: Duprat\&C, 1914.

ALMEIDA, Cândido Mendes de. "Notas para a história pátria" in Revista do Instituto Histórico e Geográfico Brasileiro. Rio de Janeiro, parte II, v. 40, p. 277-364, 1877. Disponível em http://www.ihgb.org.br/rihgb/rihgb1877t00402.pdf Acesso em: 10 ago. 2010.

ANCHIETA, J. de. Cartas: Informações, fragmentos históricos e sermões. Belo Horizonte: Itatiaia, São Paulo: Edusp, 1988.

ANCHIETA, J. de. Informação do Brasil e de suas capitanias [1584]. São Paulo: Obelisco, 1964 (Cadernos de História, 3).

BERTHOLINI, ZHÔ. Poética Urbana, Coleção Poéticas, Santo André: Editora Alfarrabio 1996.

CALLADO, Antonio. A cidade assassinada. Santo André: DEC, s.d..

Cartas Avulsas - Cartas jesuíticas II (1550-1568). Rio de Janeiro: Officina Industrial Graphica, 1931.

Cartas Jesuíticas III-IV. Rio de janeiro: Imprensa Nacional, 1887.

Cartas, Informações, fragmentos históricos e sermões do Padre Joseph de Anchieta, S. J. (1554-1594). Rio de Janeiro: Civilização Brasileira S.A., 1933.

CHARLEVOIX, Pedro Francisco Javier de. Historia Del Paraguay. Madri: Librería General de Victoriano Suárez, 1914.

CORTESÃO, Jaime. A fundação de São Paulo, capital geográfica do Brasil. Rio de Janeiro: livros de Portugal, 1995.

DE DEUS, Frei Gaspar da Madre. Memórias para a História da capitania de São Vicente, hoje chamada de São Paulo. São Paulo: Livraria Martins Fontes Editora S.A., s/ data.

DIAS, Carlos Malheiro (Dir.). História da Colonização portuguesa no Brasil. V. 3: a Idade Média brasileira (1521-1580). Edição Monumental Comemorativa do Primeiro Centenário da Independência do Brasil. Porto: Litografia Nacional, 1924.

FERREIRA, Jurandyr Pires (orientador). Enciclopédia dos municípios brasileiros. Vol. XXX - São Paulo/RJ: IBGE, 1958. 
GAIARSA, Octaviano. A cidade que dormiu três séculos (Santo André da Borda do Campo; seus primórdios e sua evolução histórica: 1553- 1960). Santo André: Tipografia Bandeirante Ltda São Paulo, 1968. Primeira Edição.

GAIARSA, O. Santo André: Ontem, Hoje e Amanhã. Santo André, São Paulo: Prefeitura municipal de Santo André, 1991.

GURGEL, L. Amaral. Ensaios quinhentistas. São Paulo: Empresa Editora J. Fagundes, 1936.

História Geral do Brasil, São Paulo, 4a ed., I, São Paulo, n. 48 do III vol. das Cartas.

ISGOROGOTA, Judas. Sapatinhos de prata. São Paulo: Edição Saraiva, 1954.

LEITE, Serafim. Novas Cartas jesuíticas (de Nóbrega a Vieira). São Paulo; Rio; Recife; Porto Alegre: Companhia Editora Nacional, 1940.

. Páginas de História do Brasil. São Paulo - Rio de Janeiro - Recife: Companhia Editora Nacional, 1937. Biblioteca Pedagógica Brasileira - Série $5^{\mathrm{a}}$ Brasiliana - Vol. 93.

LEME, Pedro Taques de Almeida Paes. História da Capitania de São Vicente. São Paulo: Melhoramentos. 19-?.

LUÍS, Washington. Na Capitania de São Vicente. São Paulo: Livraria Martins Editora, 1956.

MARQUES, Manuel Eufrásio de Azevedo (coligido por). Apontamentos Históricos, geográficos, biográficos, estatísticos e noticiosos da Província de São Paulo seguidos da cronologia dos acontecimentos mais notáveis desde a fundação da capitania de São Vicente até o ano de 1876. São Paulo: Livraria Martins Editora S.A., 1952. Tomo II.

NEVES, João Alves das. Revista das Comunidades de Língua Portuguesa João Ramalho. N. 19. São Paulo, 2003.

PATERNOSTRO Filho, Luiz (direção técnica geral). Catálogo Oficial da Exposição Industrial do IV centenário da fundação de Santo André da Borda do Campo. 1553/1953. São Paulo: Empresa Editora Cicerone Ltda, 1953.

Revista do Instituto Histórico e Geográfico de São Paulo, no volume VII, de 1902. São Paulo: Typographia do Diário Oficial, 1903.

SAMPAIO, Teodoro. São Paulo nos século XIX e outros ciclos históricos. $2^{\mathrm{a}}$ edição. Petrópolis: Vozes; São Paulo: Secretaria da Cultura, ciência e tecnologia, 1978. Dimensões do Brasil, volume 11. 
SANTOS, Aldo; VALIM, Ana (pesquisa e texto). João Ramalho: de traficante de índios a nome de medalha. São Paulo: CAPES, $2^{a}$ edição. 1997.

SCHMIDEL, Ulrico. Relatos de La conquista Del rio de La Plata y Paraguay. 1534-1554. Madri: Alianza Editorial, 1986.

TAUNAY, Affonso de E. João Ramalho e Santo André da Borda do Campo. São Paulo: Revista dos Tribunais, 1968.

VASCONCELOS, Simão de. Chronica da Companhia de Jesu do Estado do Brasil e do que obraram seus filhos n'esta parte do novo mundo. Lisboa: Casa do Editor A. J. Fernandes Lopes, 1865. Disponível em http://143.107.31.150/bibliotecaPdf/Lt-456.1 Original WEB.pdf Acesso em: 08 ago. 2010.

Crônica da Companhia de Jesus. Petrópolis: Editora Vozes, 1977.

\section{LIVROS}

ABUD, Kátia Maria. O sangue intimorato e as nobilíssimas tradições. São Paulo: FFLCH, 1985. Tese de doutorado.

ANDERSON, Benedict. Comunidades imaginadas. São Paulo: Companhia das Letras, 1991.

ARAUJO, Karina Anhesini. Intercâmbios intelectuais e a construção de uma história: Afonso d'Escragnole Taunay (1911-1929). Franca: UNESP, 2003. Dissertação de mestrado.

ARMELINI, Ângela Inês Micheletti da Silva Quintino. A preservação do patrimônio em Santo André: uma avaliação sobre a contribuição do uso cultural em imóveis tombados. São Paulo, 2008. Dissertação de mestrado.

BANN, Stephen. As invenções da História. Ensaios sobre a representação do passado. São Paulo: Editora da Universidade Estadual Paulista, 1994.

BARDI, Pietro Maria. Miguel Dutra, o poliédrico artista paulista (Itú,1810 Piracicaba,1875). São Paulo: Museu de Arte de São Paulo Assis Chateaubriand, 1981.

BLANCO JR, Cid. As transformações nas políticas habitacionais brasileiras nos anos 1990: o caso do programa integrado de inclusão social da Prefeitura de Santo André. São Carlos, 2006. Dissertação de mestrado.

CARPIM, Thais Regina Pavez. Políticas públicas e ampliação de capital social em comunidades segregadas: o programa Santo André mais igual. São Paulo, 
2005. Dissertação de mestrado.

CATROGA, Fernando. Nação, mito e rito. Fortaleza: Edições NUDOC/Museu do Ceará, 2005.

CERTEAU, Michel de. A escrita da história. Rio de Janeiro: Editora Forense Universitária, 1982.

Coleção das Leis e decretos do Estado de São Paulo. Volume 58 - 1938, Quarto Trimestre - Quarto Volume. São Paulo: Imprensa Oficial do Estado, 1939.

Coleção das Leis e decretos do Estado de São Paulo. Quarto Trimestre - Quarto Volume - 1944. São Paulo: Imprensa Oficial do Estado, 1945.

Coleção das Leis e Decretos do Estado de São Paulo de 1948. Tomo 54. Quarto trimestre - Quinto Volume. São Paulo: Imprensa Oficial do Estado, 1949.

Coleção das leis e decretos do estado de São Paulo de 1553. Tomo 63. Quarto trimestre. Segundo Volume. São Paulo: Imprensa Oficial do Estado, 1954.

Congresso de História da Região do Grande ABC. Santo André: Prefeitura do município de Santo André, 1990.

CORREIA, Eduardo Luiz. A viagem interrompida. São Paulo, 2004. Dissertação de mestrado.

História oral com participação comunitária. São Paulo: Annablume, 2004.

COSTA, Luís Augusto Maia. O ideário urbano paulista na virada do século. 0 engenheiro Teodoro Sampaio e as questões territoriais e urbanas modernas (1886-1903). São Carlos (SP): RIMA, FAPESP, 2003.

CRISTIANINI, Adriana Cristina. Atlas semântico lexical da região do Grande ABC. São Paulo, 2007. Tese de doutorado.

CRUZ, Júlio (editor). Um olhar sobre Vouzela. Viseu: Edem Gráfico,S.A., 1999.

CRUZ, Thais Fátima dos Santos. Paranapiacaba: a arquitetura e o urbanismo de uma vila ferroviária. São Carlos, 2007. Dissertação de mestrado.

DEBES, Célio. Washington Luís (1869-1924). São Paulo: Imprensa Oficial, 1994.

DENALDI, Rosana. Políticas de urbanização de favelas: evolução e impasses. São Paulo, 2003. Tese de doutorado.

ELLIS, Myriam; HORSCH, Rosemarie Erika. Afonso d'Escragnole Taunay no centenário do seu nascimento. São Paulo: Secretaria da cultura, ciência e tecnologia, 1977.

FERREIRA, Antonio Celso. A epopéia bandeirante: Letrados, Instituições, 
invenção histórica (1870-1940). São Paulo: Editora da UNESP, 2002.

FERRETTI, Danilo José Z. A construção da paulistanidade. Identidade, historiografia e política em São Paulo (1856-1930). São Paulo: FFLCH-USP, 2004. Tese de doutorado.

GAIARSA, Octaviano Armando. Brasões e bandeiras do município de Santo André - História. Santo André: Public Grafica e editora Ltda, 2001.

GOFF, Jacques Le. "Memória" in Enciclopédia Einaudi. Volume 1. MemóriaHistória.

GLEZER, Raquel. Chão de terra e outros ensaios sobre São Paulo. São Paulo: Alameda, 2007.

GUIDES, Fátima Regina Mônaco. Moradias urbanas em Santo André (19001950): caracterização da arquitetura popular e seus meios de produção. São Paulo, 2008. Dissertação de mestrado.

HOBSBAWM, Eric; RANGER, Terence na obra A invenção das tradições. São Paulo: paz e terra, 2006. $4^{\mathrm{a}}$ edição.

HOLANDA, Sérgio Buarque; CAMPOS, Pedro Moacyr. (direção). História geral da civilização brasileira. Tomo 1 - Época Colonial - Primeiro volume - Do descobrimento à expansão territorial. São Paulo; Rio de Janeiro: DIFEL, 1976. Quinta edição.

KANTOR, Iris. Esquecidos e renascidos. Historiografia Acadêmica Lusoamericana (1724-1759). São Paulo-Salvador: Editora Hucitec/Centro de Estudos Baianos/UFBA, 2004.

LOZANO, Márcia da Silva. A educação ambiental em uma escola do município de Santo André: análise situacional. São Paulo, 2003. Dissertação de mestrado.

MARCELLOS, Lincoln Nogueira. Desenvolvimento regional e identidade industrial: a faculdade de ciências econômicas e administrativas de Santo André (1950-1960). São Caetano do Sul: IMES, 2006. Dissertação de Mestrado em Administração.

Disponível em http://www.uscs.edu.br/posstricto/administracao/dissertacoes/2006/lincoln marcellos Idissertacao lincoln marcellos.pdf. Acesso em: 31 jul. 2010.

MARTINS, José de Souza. Subúrbio: vida cotidiana e história no subúrbio da cidade de São Paulo: São Caetano, do fim do Império ao fim da república Velha. São Paulo: Hucitec / São Caetano do Sul: Prefeitura de SCS, 1992.

MARX, Murilo. Cidade no Brasil em que termos? São Paulo: Studio Nobel Ltda, 1999.

MEDICl, Ademir. Migração, urbanismo e cidadania: a história de Santo André contada pelos seus personagens. Santo André: Prefeitura Municipal de Santo 
André, 19-?.

MELLO JR, Donato; SOUZA, Jonas Soares de. A contribuição de Miguelzinho Dutra à iconografia paulista do século XIX. Itu (SP), 2000.

MONTEIRO, Arlete Assumpção. Santo André: dos primórdios à industrialização. Um estudo sobre os imigrantes ao longo da SO Railway. São Paulo: FFLCHUSP, 1995. Tese de doutorado.

Moradia social em áreas de mananciais. São Paulo: Annablume, 2004.

MORAES, Maria Blassioli. A ação social católica e a luta operária: a experiência dos jovens operários católicos em Santo André (1954-1964). São Paulo, 2003. Dissertação de mestrado.

NEVES, Cylaine Maria das. A vila de São Paulo de Piratininga: fundação e representação. São Paulo: FFLCH-USP, 2004. Dissertação de mestrado.

NOGUEIRA, Bene. Trajetória imigrante, tempo de lembrar. Santo André: prefeitura, 2000.

NORA, Pierre. "Présentation/ La Fin de l'Histoire-Mémoire" in Les Lieux de Mémoire. Vol.1. Paris: Gallimard, 1984.

OLIVEIRA Jr, Paulo Cavalcante de. Afonso d' E. Taunay e a construção da memória bandeirante. Rio de Janeiro: Instituto de Filosofia e Ciências Sociais da Universidade Federal do Rio de Janeiro, 1994. Dissertação de mestrado.

PASSARELLI, Sílvia Helena F. Levantamento cartográfico de Santo André. São Paulo: FAU-USP, 1993. Trabalho programado para o curso de pós graduação.

PETRONE, Pasquale. Aldeamentos paulistas. São Paulo: EDUSP, 1995.

PINHO, Rodrigo Altair. Santo André (re) ordenação sócio espacial e implicações do período técnico- científico- informacional a partir dos anos 90 . São Paulo, 2007. Dissertação de mestrado.

PULHEZ, Magaly Marques. Espaços de favela, fronteiras do ofício; histórias e experiências contemporâneas de arquitetos em assessorias de urbanização. São Carlos, 2007. Dissertação de mestrado.

RIBEIRO, Laerte M. Magno. 20 gerações de João Ramalho e Bartyra, seus descendentes mineiros de andrelândia e outras grandes famílias. São Paulo: L.M.M. Ribeiro, 1989.

RODRIGUES, Marly. Linhas e trajetos: história do serviço de transporte coletivo em Santo André. Santo André: Memórias, acessória e projetos, 2001.

ROSSI, Márcio José. João Ramalho: o precursor de uma geração. Trabalho de evento - resumo - nacional. São Paulo: USP, 2007. CD-ROM. 
SAMPAIO, Teodoro. O rio São Francisco e a Chapada Diamantina. São Paulo: Companhia da Letras, 2007.

SANTOS, Magda Carmo dos. Águas revoltas: história das enchentes em Santo André. Santo André: Santo André. Prefeitura municipal, 2002.

SANTOS, Wanderley dos. Antecedentes históricos do ABC paulista. 1550-1892. Prefeitura do município de São Bernardo do Campo: SECE, 1992.

SCHWARCZ, Lilia M. O espetáculo das raças - cientistas, instituições e questão racial no Brasil - 1870-1930. São Paulo: Companhia das Letras, 1993.

SILVA, José Armando Pereira da. A cena brasileira em Santo André: $\mathbf{3 0}$ anos do teatro municipal. Santo André: Fundo de Cultura do Município de Santo André, 2001.

SILVA, José Armando Pereira da. Guido Polanas: retratos da cidade. Santo André: Fundo de Cultura do município de Santo André, Secretaria de Cultura, Esporte e Lazer, 2002.

SILVA, Rosângela Augusta. A qualidade dos mananciais e a inclusão social: a experiência de Santo André na gestão da Bacia Billings. São Paulo, 2003. Dissertação de mestrado.

SOUZA, Jonas Soares de. Miguelzinho Dutra: traços e troças da Itu oitocentista, 2004.

Sumário de dados de 2008. Santo André: Prefeitura de Santo André, s.d.

TERRAZAS, Marcelo (coordenação). Políticas de inclusão social de Santo André: Programa de apoio ás populações desfavorecidas, Programa Santo André mais igual. São Paulo: Projeto empreendedor popular: Banco do povo, 2004.

TIZIO, Ibere Luiz Di. Santo André: a causa toponímica na denominação de seus bairros. São Paulo: FFLCH-USP, 2009. Tese de doutorado.

TORRES, Ruiz Pedro. "Les usages politiques de I'histoire em Espagne. Formes limites et contradictions" in HARTOG, François; REVEL, Jacques (org.). Les usages politiques du passe. Paris: Éditions de L'EHESS, 2001.

UVINHA, Ricardo RICCI. Turismo de aventura: uma análise do desenvolvimento desse segmento na vila de Paranapiacaba. São Paulo, 2003. Tese de doutorado.

VARGAS, Maria Ester. João Ramalho - Bandeirante de Lafões. Viseu: Tip. Beira Alta Ltda, 2000. Coleção "Homens de quinhentos".

VELLOSO, Augusto Carlos Ferreira. Os artistas Dutra: oito gerações: presença de mais de dois séculos na arte do Brasil. São Paulo: Imprensa Oficial do Estado de São Paulo: Sociarte 2000. 
XAVIER, Luiz Felipe. O canteiro é o banheiro, o desenho é a obra. São Paulo, 2009. Dissertação de mestrado.

\section{ARTIGOS E REVISTAS}

AMARAL, Pedro Ferraz do. "Taunay o historiador da vila de São Paulo" in Revista do Arquivo Municipal de São Paulo. N. 189, p. 3/16. São Paulo, 1977.

BLAJ, Ilana. "Mentalidade e sociedade: revisitando a historiografia sobre São Paulo colonial" in Revista de História. São Paulo: USP, n. 142/143, 2000, p. 239/260.

DEBES, Célio. "Washington Luís historiador" in Revista do IHGSP, 1990, vol. 85.

FERLINI, Vera Lúcia Amaral. "João Ramalho: como se índio fosse" in Cadernos Paulistas: história e personagens. São Paulo: Imprensa Oficial do Estado, 2002.

FERRETTI, D. J.; CAPELATO, Maria Helena Rolim. "João Ramalho e as origens da nação: os paulistas na Comemoração do IV centenário da descoberta do Brasil" in Tempo, Rio de Janeiro, v. 4, n. 8, p. 67/87, 1999.

KULCSAR, Rosa. "O resgate da memória da Fundação Santo André" in Revista Fundação Santo André. V. 1., n. 1., p. 11/29, 2002.

LEONZO, Nanci. "Reduto intelectual na intimidade: O Instituto histórico e geográfico brasileiro" in Revista do Instituto de Relações Sociais e Industriais. São Bernardo do Campo, n. 8, p. 4/51, 1987.

MATTOS, Odilon Nogueira de. "Afonso de Taunay e o Instituto Histórico e geográfico de São Paulo" in Revista do IHGSP, v. 88, p. 47/52, 1993.

NEVES, João Alves das (diretor e editor). João Ramalho. São Paulo: Revista das comunidades de língua portuguesa. N. 19, 2003.

SOUZA, Laura de Mello e. "Vícios, virtudes e sentimento regional: São Paulo, da lenda negra à lenda dourada" in Revista de História. São Paulo: USP, n. 142/143, 2000. 


\section{DICIONÁRIOS}

SERRÂO, Joel. Pequeno Dicionário da história de Portugal. Porto: Figueirinhas, 1993.

WEISZFLOG, Walter (editor). Michaellis: moderno dicionário de Língua Portuguesa. São Paulo: Melhoramentos, 1998.

\section{INTERNET}

http://amigoscelsodaniel.blogspot.com/2007/09/biografia.html Acesso em: 30 jul. 2010.

http://augus54.wordpress.com/os-prefeitos. Acesso em: 31 jul. 2010.

http://biografias.netsaber.com.br/ver_biografia_c_4108.html. Acesso em: 30 jul. 2010.

http://cvc.instituto-camoes.pt/figuras/jcortesao.html Acesso em: 03 ago. 2010.

http://dicionarioandreensedepersonalidades.blogspot.com/2009/03/zampol-familiaem-andamento_21.html. Acesso em: 31 jul. 2010.

http://letras.terra.com.br/hinos-de-cidades/942119/. Acesso em: 01 ago. 2010.

http://portaldaculturanegra.wordpress.com/2008/08/28/teodoro-fernandes-sampaio/ Acesso em: 03 ago. 2010.

http://www.academia.org.br/abl/cgi/cgilua.exe/sys/start.htm?infoid=152\&sid=138\&tpl= printerview. Acesso em: 30 jul. 2010.

http://www.al.sp.gov.br/portal/site/Internet/IntegraDDILEI?vgnextoid=2ddd0b9198067 
110VgnVCM100000590014acRCRD\&tipoNorma=9 Acesso em: 19 ago. 2010.

http://www.arqnet.pt/portal/biografias/jaime_cortesao.html Acesso em: 03 ago. 2010.

http://www.cdpb.org.br/dic_bio_bibliografico_almeidajunior.html Acesso em: 10 ago. 2010.

http://www.cmsandre.sp.gov.br/legislativo/historia.htm Acesso em: 17 mai. 2010.

http://www.cm-sjm.pt/175 Acesso em 04/08/2010

http://www.ecsantoandre.com.br/simbolos.html. Acesso em: 02 ago. 2010.

http://www.esec-dr-serafim-leite.rcts.pt/escola/projedu/projedu.htm Acesso em: 04 ago. 2010.

http://www.ihgs.com.br/cadeiras/patronos/freigaspar.html Acesso em: 04 ago. 2010.

http://www.itaucultural.org.br/aplicExternas/enciclopedia_IC/index.cfm?fuseaction=art istas_biografia\&cd_verbete=929\&cd_idioma=28555. Acesso em: 1 ago. 2010.

http://www.netsaber.com.br/biografias/ver_biografia_c_1069.html acesso em: 03 ago. 2010.

http://www.netsaber.com.br/biografias/ver_biografia_c_4830.html acesso em: 04 ago.2010

http://www.nossosaopaulo.com.br/Reg_13/Reg13_SantoAndre.htm Acesso em: 21 ago. 2010.

http://www.novomilenio.inf.br/santos/h0333a11.htm Acesso em: 04 ago. 2010.

http://www.prefeitura.sp.gov.br/cidade/secretarias/cultura/bibliotecas/bibliotecas_bairr o/bibliotecas_a_l/affonsotaunay/index.php?p=93 Acesso em: 04 ago. 2010. 
http://www.santoandre.sp.gov.br/bn_conteudo.asp?cod=1506 Acesso em: 30 mar. 2009.

http://www.santoandre.sp.gov.br/pop_up_noticia.asp?cod=6358 Acesso em: 30 jul. 2010.

http://www.senado.gov.br/senadores/senadores_biografia.asp?codparl=1535\&li=17\& lcab=1878-1881\&lf=17 Acesso em: 10 ago. 2010.

http://www.uscs.edu.br/posstricto/administracao/dissertacoes/2006/lincoln_marcellos /dissertacao_lincoln_marcellos.pdf. Acesso em: 31 jul. 2010.

http://www.puc-rio.br/pibic/relatorio_resumo2009/relatorio/his/livia_u.pdf Acesso em: 04 ago. 2010.

http://wikimapia.org/37983/pt/Pra\%C3\%A7a-Quarto-Centen\%C3\%A1rio. Acesso em: 31 jul. 2010. 


\section{ANEXOS}

1. História da cidade - site da Prefeitura de Santo André.

2. História da Câmara - Site da Câmara dos vereadores.

3. Santo André, caminhos percorridos - Museu de Santo André Dr. Octaviano Gaiarsa.

4. Primeiro Brasão de Santo André. 


\section{ANEXO 1 - HISTÓRIA DA CIDADE - SITE DA PREFEITURA DE SANTO ANDRÉ}

\section{Histórico}

Para contar a história da região na qual Santo André está inserida, temos que retomar, de maneira sucinta, parte da história do Brasil Colonial. Nos primeiros anos dessa história os portugueses tinham grande preocupação em defender as costas brasileiras de possíveis invasões de franceses e holandeses, pois estes dois países não compartilharam da divisão expressa pelo Tratado de Tordesilhas que dividiu o Novo Mundo, a terra a ser descoberta, entre portugueses e espanhóis.

No início do século 16 os países que tivessem terras onde pudessem explorar as riquezas minerais, em especial ouro e prata, estavam à frente dos demais pois essas eram as moedas correntes, indicadoras de riqueza. Explica-se por aí o interesse pelas terras dessa vasta colônia portuguesa. Devido a vários ataques às suas terras, a partir de 1530 Portugal intensificou a colonização das costas brasileiras. Nesse contexto é enviado para cá, por ordem de D.João III, rei de Portugal, Martim Afonso de Souza com a incumbência de fundar vilas para fortificar o litoral.

Aliada a essa história está a figura de João Ramalho, português que representava, nesse momento, uma porta de entrada para o contato com os índios e para a colonização, pois ele conhecia algumas tribos e conseguia se comunicar com elas.

Em contrapartida a sua ajuda, João Ramalho solicitava, desde o início, que o local em que vivia, situado acima da Serra do Mar, fosse transformado em vila. Sua petição foi negada durante vários anos, pois pretendia-se povoar o litoral e não o interior. Seu pedido foi atendido apenas em 8 de abril de 1553, quando foi criada a vila pelo Governador Geral Tomé de Souza. Seu nome era Santo André da Borda do Campo.

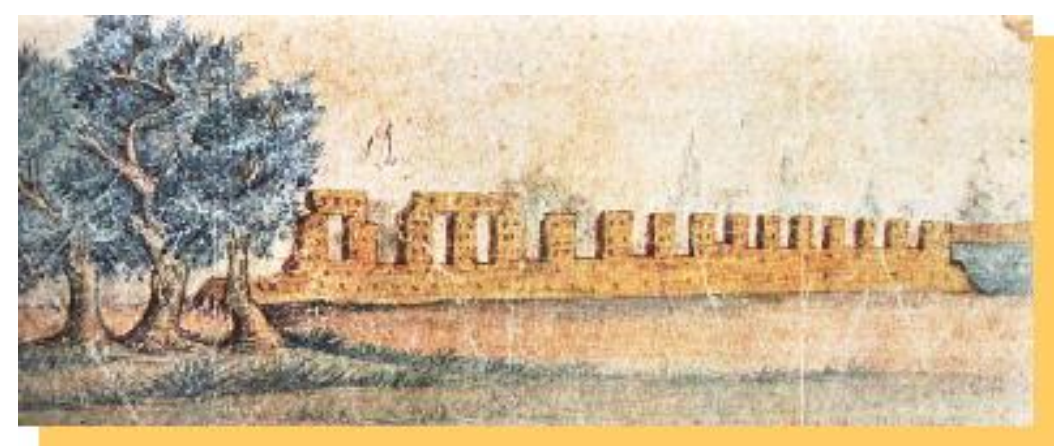

\section{Ruinas de Santo André da Borda do Campo. \\ Autoria : Miguel Dutra \\ Acervo : Museu Paulista}

Nesse período, a busca de metais impulsionou as entradas para o interior e a vila foi se desenvolvendo. Os jesuítas, instalados em São Vicente, tinham interesse em transferir seu colégio para próximo dessa região, nos campos de Piratininga, pois havia uma grande evasão de pessoas do litoral para o interior. Tal fato ocorreu a 25 de janeiro de 1554, com a criação da Aldeia de São Paulo de Piratininga.

Dificuldades de subsistência e de proteção fizeram com que a vila de Santo André fosse transferida para São Paulo de Piratininga em 1560, através de proposta do Padre Manoel da Nóbrega ao Governador Geral Mem de Sá.

A partir de então, Santo André deixou de existir enquanto unidade administrativa, passando a ser um bairro de São Paulo. A região passou por um período de estagnação, tornando-se 
local de passagem entre o Porto de Santos, a capital e o interior. No entanto, já em 1561, grande parte das terras foi concedida como sesmaria a Amador de Medeiros, ouvidor da Capitania de São Vicente. Boa parte dessa sesmaria foi repassada, em 1637, à Ordem de São Bento, formando-se ali a Fazenda São Bernardo, área atualmente ocupada em grande parte pelo município de São Bernardo do Campo. Outra área importante de domínio dos beneditinos era a Fazenda São Caetano, doada à Ordem em 1631 pelo Capitão Duarte Machado e sua esposa Joana Sobrinha. As outras terras eram menores e foram passando por vários donos até o início do século 20, quando foram loteadas.

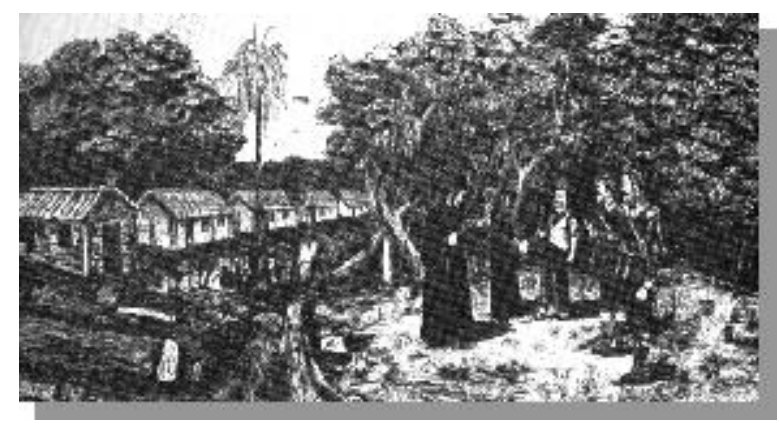

Monges beneditinos tomam posse das terras doadas por Duarte Machado localizadas no Tijucussú, atual São Caetano do Sul. In: Martins, José de Souza, São Caetano do Sul em IV Séculos de História.

Nesse período a atividade econômica ficou restrita à subsistência e à locação de pastagens para as tropas. As duas fazendas dos beneditinos São Bernardo e São Caetano tinham uma atividade mais regular: a primeira produzia gêneros alimentícios e na segunda fabricavam-se tijolos e artefatos de cerâmica. Essas fazendas ficaram sob a propriedade dos beneditinos até 1870, quando foram compradas pelo Estado para a criação de colônias de imigrante. Antes disso, porém, ao redor da fazenda São Bernardo foi se criando um pequeno núcleo urbano, que mais tarde iria garantir a criação do município de São Bernardo.

Um outro fator importante no contexto de modernização da região em meados do século XIX, foi a instalação da ferrovia nas proximidades do Rio Tamanduateí. Esse empreendimento visava a melhoria do transporte de produtos agrícolas do interior para o Porto de Santos, em especial o café que começava a ser produzido em larga escala na Província de São Paulo. Tal situação começou a atrair indústrias que se aproveitavam das facilidades de transporte, da disponibilidade de áreas próximas à linha férrea e ao rio, além dos incentivos fiscais apresentados pelo município.

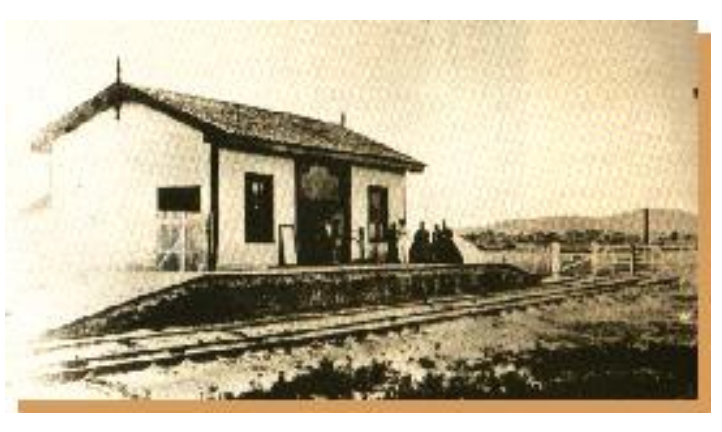

Estação ferroviária de São Bernardo, atual Santo André,1867.Col: RFFSA, reprodução:Museu de Santo André.

Em 1889, quando foi criado o município de São Bernardo, este nasceu sob a marca da industrialização, utilizando, predominantemente, a mão de obra de imigrantes. Este 
município abrangia toda a região do Grande $A B C$. As indústrias que se instalavam na nova cidade eram em geral ligadas à produção química, têxtil e de móveis. Além disso, foram surgindo pequenos negócios como carpintarias, funilarias, sapatarias, barbearias, pequenas pensões e restaurantes, que foram dando uma feição mais urbana à região. Nesse contexto ressurge o termo Santo André, nomeando o distrito criado em 1910 e que compreendia áreas próximas à Estação.

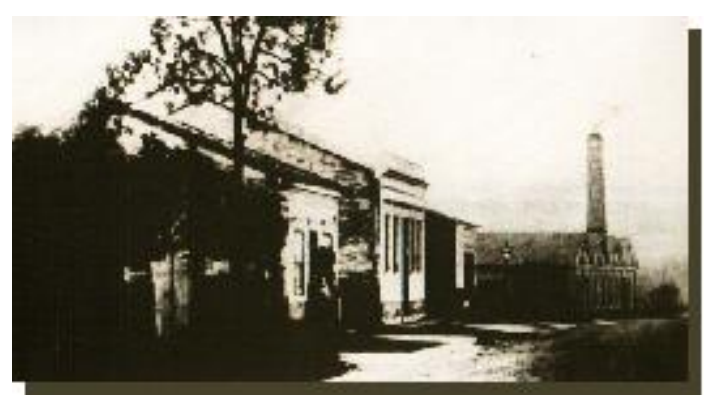

Rua Cel. Oliveira Lima, vendo-se ao fundo a Companhia Streiff,1899. Col: Euclydes Rocco, acervo:Museu de Santo André

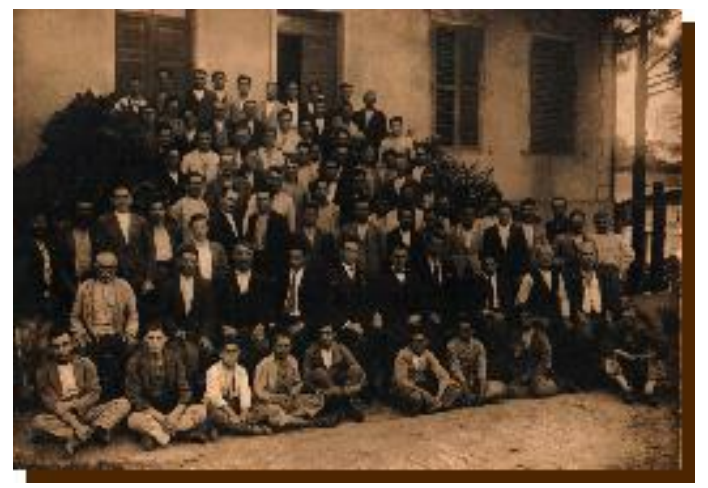

Grupo de operários da Companhia Streff, Rua Cel. Oliveira Lima,c.déc.1920. Col:Mário Batista Canever, acervo: Museu de Santo André

A expansão industrial remonta ao final do século 19 e caracterizou-se por muito tempo por um misto de produção industrial e artesanal. As primeiras indústrias foram a Tecelagem Silva Seabra \& Cia, conhecida também como Fábrica Ypiranguinha por estar sediada na região conhecida por esse nome. Foi inaugurada em 1885 e produzia brim de algodão. Esta indústria operou até a década de 1970. Outra tecelagem instalada ainda no século 19 foi a Bergman, Kowarick \& Cia que iniciou suas atividades em 1889 e fabricava casemiras. A primeira fábrica de móveis foi a Companhia Streiff de São Bernardo, inaugurada em 1897 e produzia, principalmente, cadeiras.

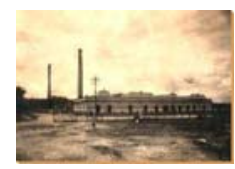

Fábrica de Casemiras Kowarick, situada junto á Estação, onde hoje há um supermecado,déc.de 1920.Col:Mário Batista Canever, acervo:Museu de Santo André 


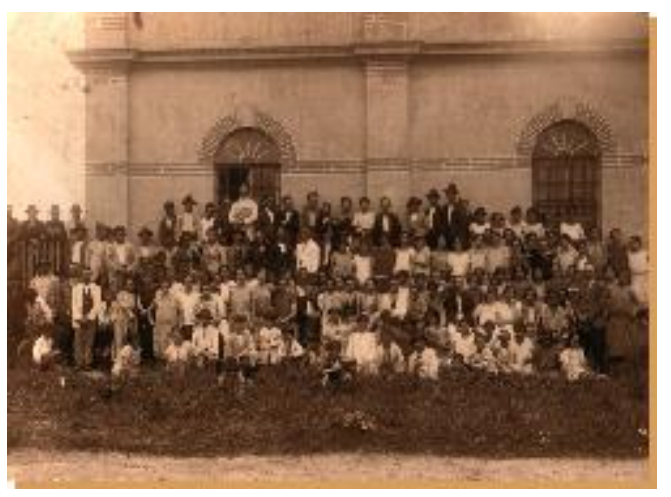

Funcionários da Fábrica de Casemiras Kowarick, déc. de 1920.Col:Mário Batista Canever,acervo:Museu de Santo André

Além disso, outras tecelagens menores foram se instalando no início do século 20 , como a Fiação e Tecelagem Santo André (1908), a Fábrica de Tecidos de Algodão (1920), a Fábrica de Tecidos São Geraldo (1926), o Jutifício Maria Luiza Ltda (1933), entre outras. Essas empresas eram, em sua maioria, pequenos empreendimentos gerenciados por seu proprietário. Todas já desapareceram, principalmente por não conseguirem se impor às inovações tecnológicas, após a década de 1950.

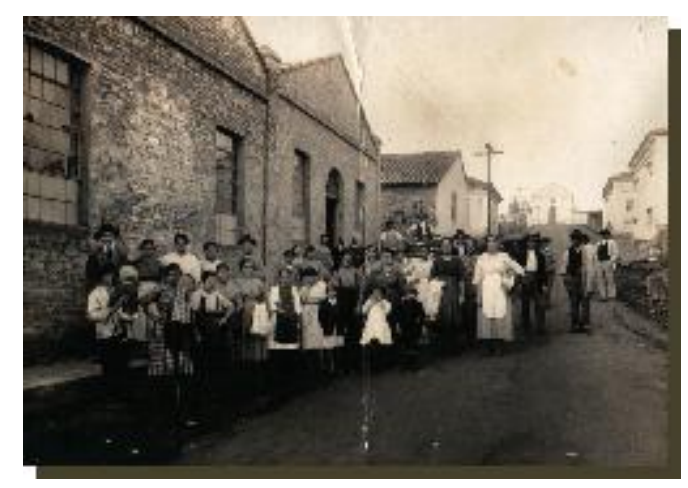

Exterior da Tecelagem Zanolli e seus funcionários, localizada á Rua D. Duarte Leopoldo e Silva.Ao fundo vê-se a antiga Igreja Matriz de Santo André,1925. Col: Silvia Zanolli Brunoro Daniel, acervo museu de Santo André.

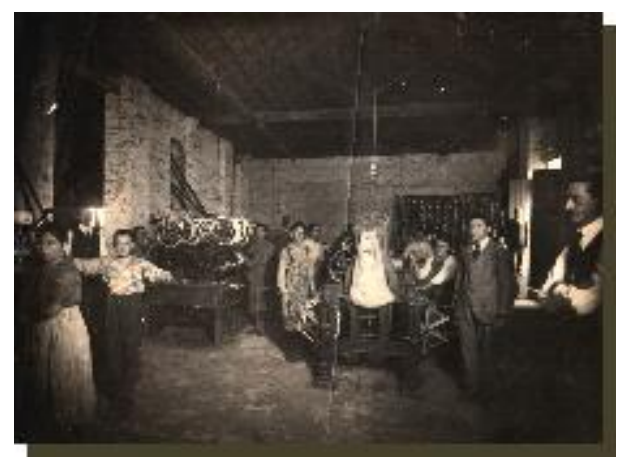

Funcionários da Tecelagem Zanolli no interior da fábrica, 1925. Col: Silvia Zanolli Brunoro Daniel, acrevo: Museu de Santo André.

Outras, porém, fundadas nesse mesmo período modernizaram-se, como a Companhia Chimica Rhodia S/A e a Companhia Brasileira de Seda Rhodiaseta. 


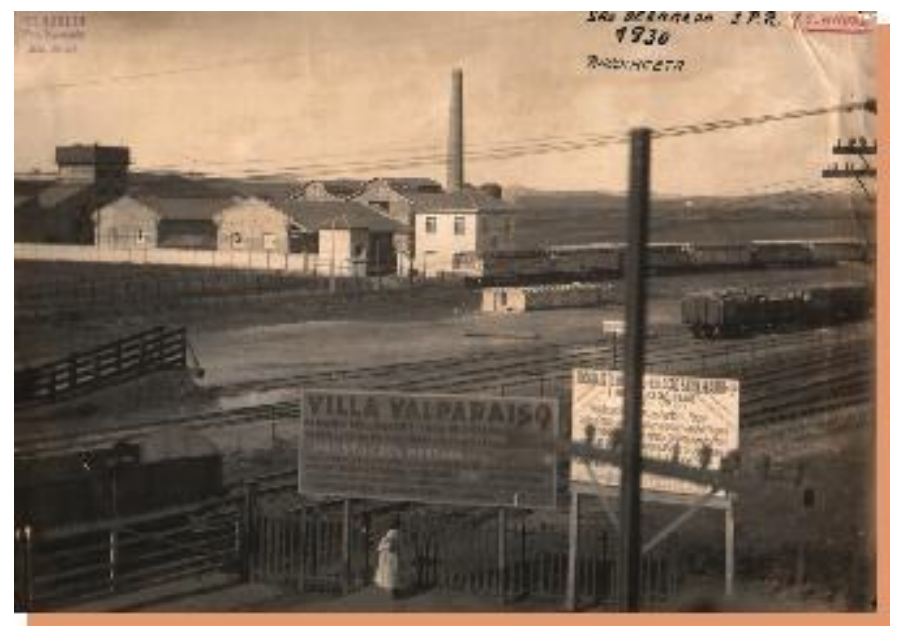

Fábrica Rhodiaceta ao fundo e Estrada de ferro de São Paulo Railway á frente,1930.A fábrica ainda ocupa essa área.Foto Carlos Haukal.Col:Dalvira Ribeiro Cangussú, acervo:Museu de Santo André.

O distrito de Santo André abrigava na década de 1930 várias indústrias importantes, possuía a Estação de São Bernardo por onde era transportada grande parte dos produtos aqui produzidos e tinha entre seus moradores vários políticos influentes. Tal situação levou à transferência da sede do município de São Bernardo para Santo André, em 1939. Toda a região do Grande $A B C$, composta por vários distritos, passou, então, a ser denominada pelo nome Santo André.

No entanto, já na década de 1940 iniciaram-se vários movimentos emancipacionistas e os distritos foram tornando-se municípios. Em 1945 foi a vez de São Bernardo do Campo, em 1949 São Caetano do Sul e em 1953 Mauá e Ribeirão Pires. A partir de então Santo André passou a ter uma área de 174,38 quilômetros quadrados, contando com os seguintes distritos: Sede, Capuava e Paranapiacaba

Na década de 1950, além dessas mudanças, outras puderam ser sentidas no que se refere à tipologia das indústrias da região. Com os investimentos estatais e o capital estrangeiro ocorreu um crescimento no setor automobilístico, mecânico, metalúrgico e de material elétrico. Santo André passou a abrigar várias indústrias de auto-peças.

A indústria foi, então, delineando um outro perfil. A mão de obra tornou-se mais especializada e as máquinas mais produtivas. Neste momento a mão de obra deixou de ser determinante para o aumento da produção.

Na década de 1970 houve um momento de expansão e concentração da indústria na Grande São Paulo. Foi o período denominado de "milagre econômico". Na década seguinte o ritmo de crescimento sofreu um decréscimo, culminando com a recessão dos anos 80.

Nos anos 90 a produção industrial continuou desacelerada, com os incentivos fiscais voltados para outras áreas do estado de São Paulo, além das dificuldades de transporte e o custo de mão de obra. $O A B C$ e, em especial Santo André, perdeu várias indústrias. Hoje em dia, há um grande esforço do setor público e da sociedade para a manutenção das indústrias existentes. Além disso, tem-se observado um aumento de atividades nos setores de serviços e no comércio. O desafio do início deste século 21 está relacionado à criação de novas alternativas para a cidade que vai se transformando, garantindo melhores condições de vida a seus moradores. 


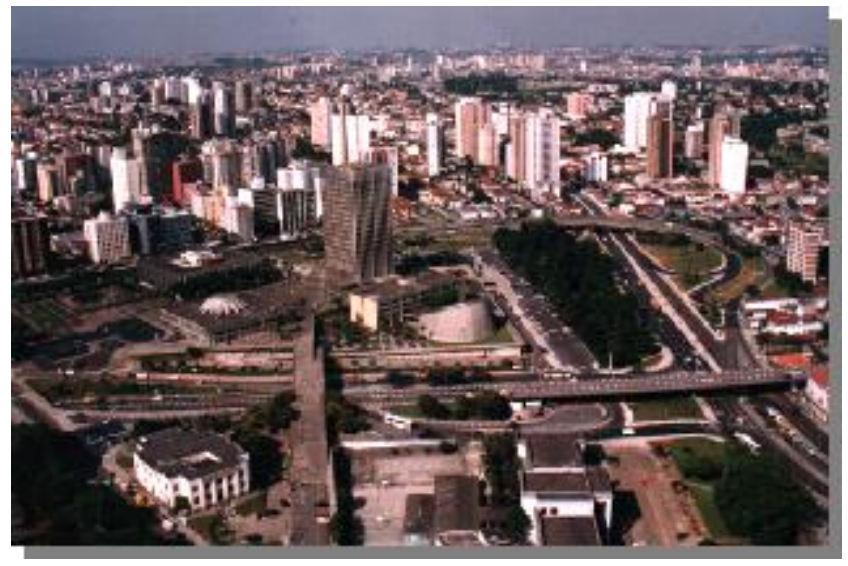

Vista de centro de Santo André, 1998. Foto: Beta Garavello. Col: PMSA, acervo: Museu de Santo André.

Tratado de Tordesilhas - foi celebrado em 1494 em Tordesilhas, município da província de Valladolid, na Espanha. Era um acordo entre os Reis Católicos da Espanha Fernando e Isabel e o rei de Portugal, D. João II, que repartia entre os dois reinos a posse das terras descobertas e a descobrir. Delimitava as esferas de ação de Portugal e Espanha nos descobrimentos marítimos, traçando uma linha imaginária a 370 léguas das Ilhas de Cabo Verde, no Oceano Atlântico. As terras a leste pertenceriam a Portugal e à oeste seriam da Espanha. Esse tratado vigorou até 1750 quando foi revogado.

Martim Afonso de Souza - nasceu em Vila Viçosa, Portugal em 1500 e morreu em Lisboa a 21 de julho de 1564.Era filho do fidalgo Lopo de Sousa e de D. Brites de Albuquerque. Foi militar e administrador colonial da Coroa Portuguesa.

Foi nomeado pelo rei de Portugal, D. João III, capitão-mor da armada contra os franceses na costa do Brasil. A armada partiu de Lisboa no dia 03 de dezembro de 1530 e em 1531 percorreu toda a costa brasileira, aportando no litoral paulista. Em 22 de janeiro de 1532 criou a Vila de São Vicente primeira vila do Brasil.

Aqui no Brasil, Martim Afonso tinha plenos poderes, inclusive sobre a vida e a morte das pessoas, além de distribuir terras em sesmarias, nomear oficiais de justiça, etc. Retornou a Portugal em 1533, recebendo o título de capitão-mor do Mar das Índias e em 1534 foi nomeado donatário da Capitania de São Vicente no Brasil e governador da Índia de 1541 a 1545. Está sepultado no Convento de São Francisco em Lisboa.

João Ramalho - era português, filho de João Velho Maldonado e de Catarina Afonso de Balbode, nasceu aproximadamente em 1470 em Vouzela, distrito de Viseu, Portugal. Era casado com Catarina Fernandes das Vacas. Foi degredado para o Brasil por delitos cometidos enquanto era escudeiro da rainha. Não se sabe exatamente o ano em que João Ramalho foi deixado na costa brasileira - supõe-se que tenha sido entre 1510 e 1530.

No Brasil uniu-se à índia Bartira, posteriormente batizada como Isabel Dias. Ela era filha do Cacique Tibiriçá, da tribo Guaianazes.

Após a fundação da vila de Santo André da Borda do Campo, exerceu vários cargos nesta vila como: guarda-mor, capitão, alcaide e vereador. Faleceu em 1580, sendo provavelmente sepultado na Igreja do Colégio de São Paulo de Piratininga. 
Vila - Para se fundar uma vila e doar suas terras era necessário possuir uma carta de poderes do Rei de Portugal. A vila possuía um ordenamento jurídico-administrativo semelhante às cidades atuais. Tinha Câmara Municipal com vereadores, almotacéis vereadores que serviram a Câmara no ano anterior juiz, procurador, tesoureiro, escrivão, alcaide-mor - espécie de prefeito, além do guarda-mor - que cuidava da segurança da vila. Possuíam também um Pelourinho.

Jesuítas - ordem religiosa fundada em 1539 por Ignácio de Loyola. Tratava-se de um grupo de características militares de combate à Reforma. Nesse mesmo ano foi reconhecida como uma ordem católica romana e em 1540 foi aprovada pelo Papa Paulo III. Os jesuítas chegaram ao Brasil Bahia em 1549 e tinham como função primordial catequisar os índios, ou seja, ensinar a religião católica e as normas de conduta moral e social dos portugueses. Além disso, fundaram colégios, abriram estradas para o interior do país, etc. Entre 1504 e 1604 estiveram no Brasil 174 padres, entre eles: Manuel da Nóbrega, José de Anchieta, Leonardo Nunes e Antonio Vieira.Foram expulsos em 1759 de Portugal e suas colônias, por interferência do Marquês de Pombal. Em 1773 a Companhia foi extinta pelo Papa Clemente XIV. Em 1814 a ordem foi formalmente restaurada pelo Papa Pio VII.

Capitania - foram as primeiras divisões administrativas do Brasil, implantadas por D.João II entre os anos de 1532 e 1536. O sistema de capitanias já era usado por Portugal em Açores, Madeira e Cabo Verde, onde tinha dado certo. As terras eram doadas a donatários através da Carta de Doação que estipulava a área e do Foral que apresentava os direitos e deveres dos donatários. O intuito dessa empreitada era colonizar a colônia com o mínimo de recursos da Coroa Portuguesa. O Brasil foi dividido em quinze capitanias e a maioria delas não prosperaram. As capitanias que tiveram sucesso foram a de São Vicente e a de Pernambuco, onde houve acordos com os índios residentes naquele lugar. Nas demais Maranhão, Maranhão (2. ${ }^{\circ}$ quinhão), Ceará, Rio Grande, Itamaracá, Bahia, Ilhéus, Porto Seguro, Espírito Santo, São Tomé, Santo Amaro e Santana os portugueses estavam cercados por indígenas e as casas e canaviais eram destruídos constantemente. Tal sistema foi sendo suplantado a partir de 1549 pelo sistema de Governo-geral, onde as capitanias inexploradas foram retomadas e o governador-geral, com sua sede em Salvador, passou a ser a referência política da Colônia.

Ordem de São Bento - essa ordem foi criada por volta de 529 d.C. por São Bento, nas proximidades de Roma. A concepção dessa ordem era de que o mosteiro deveria ser uma instituição autônoma financeira e administrativamente, sendo os monges soldados de Cristo, tendo por chefe o abade. Na região do $A B C$, os beneditinos tiveram influência desde 0 século 17, quando receberam por doação terras que formariam duas fazendas: São Bernardo e São Caetano. No final do século 19 as ordens religiosas perderam seu poder, com a separação do Estado e da Igreja. As terras e propriedades dessas ordens foram vendidas ao Estado ou confiscadas e essas ordens religiosas ficaram restritas a seus mosteiros.

Tropas - as tropas de mulas surgiram como meio de transporte a partir da primeira metade do século 18. Era uma resposta à ampliação do movimento comercial entre diversos pontos do Brasil e, em especial, com Minas Gerais, onde a mineração de ouro movia a economia daquele período. Foram abertas várias estradas ligando diversas localidades como, por exemplo Sorocaba São Paulo e Viamão no Rio Grande do Sul, onde se criavam mulas, gado e cavalos. Por essas estradas eram trazidos todos os tipos de produtos: alimentos, ferramentas, tecidos, etc. O tropeiro passou a ser uma figura importante na integração espacial e no escoamento da produção de diferentes e distantes lugares.

Entre o Porto de Santos e São Paulo, havia uma rota que passava pela Serra do Mar através da Calçada de Lorena, inaugurada em 1792 e seguia por vários caminhos dentro da 
região que hoje compreende o $A B C$ : Caminho do Pilar, do Oratório, do Vergueiro, entre outros. Com isso, a região que servia de local de pastagem e pouso para os tropeiros foi sendo povoada, permitindo a posterior criação de freguesias e vilas.

Colônia de imigrantes- essas colônias foram implantadas no ABC, pelo Governo Imperial, a partir de 1877, nas antigas fazendas dos beneditinos. O intuito era de que ali se plantassem produtos agrícolas de subsistência, em apoio às grandes fazendas produtoras de café. As terras das colônias foram divididas em linhas e estas em lotes que eram entregues aos imigrantes italianos que deveriam cultivar produtos agrícolas. Com a renda gerada, poderiam abater suas dívidas com o Governo, tornando-se proprietários das terras. No entanto, a realidade era diferente. O descaso, as más condições de vida e a inaptidão das terras para o cultivo fizeram com que muitos imigrantes abandonassem seus lotes e buscassem no núcleo urbano outro tipo de atividade que lhes garantissem o sustento. Com isso, esse sistema de uso das terras foi abandonado pelo governo, que passou a estimular ainda mais as grandes propriedades que queriam o imigrante apenas como mão-de-obra barata e em larga escala, e não mais como proprietário de um lote de terra.

Site da prefeitura de Santo André

Disponível em: http://www.santoandre.sp.gov.br/bn_conteudo.asp?cod=1506 Acesso em: 30 mar. 09. 


\section{ANEXO 2 - HISTÓRIA DA CÂMARA - SITE DA CÂMARA DOS VEREADORES}

Desde a chegada do bandeirante João Ramalho até hoje, Santo André sempre ocupou lugar de destaque quanto à organização dos poderes públicos.

A Câmara Municipal de Santo André foi instalada em 29 de setembro de 1892, quando tomaram posse os primeiros vereadores.

Devido a ligações com as demais cidades, a Câmara de santo André funcionou em São Bernardo do Campo até 10 de outubro de 1937. A partir de 1948 foi instalada à rua Coronel Alfredo Fláquer, 76, onde seus trabalhos foram realizados até 24 de março de 1954. Depois mudou-se para a Rua Coronel Oliveira Lima, 252, permanecendo neste local até 27 de outubro de 1968.

Com a construção do novo prédio no Centro Cívico, à praça IV Centenário, a atual Casa de Leis foi instalada solenemente em 28 de outubro de 1968.

Desde 1948, a Câmara de Santo André passou por treze Legislaturas, tendo início, em 2005, a décima quarta. Durante toda sua trajetória, o Legislativo andreense sempre teve seu desenvolvimento voltado para uma maior participação popular. Hoje, a Casa abriga 21 vereadores, com representantes de 11 siglas partidárias.

\section{Histórico - Santo André}

A história de Santo André, dividida em duas etapas distintas, confunde-se com a história da região do Grande ABC, que hoje comporta os sete municípios: Santo André, São Bernardo do Campo, São Caetano do Sul, Diadema, Mauá, Ribeirão Pires e Rio Grande da Serra.

A primeira etapa teve vida curta. Em 8 de abril de 1553, o bandeirante J oão Ramalho, que já vivia no Brasil desde 1500, recebeu um documento garantindo-lhe a posse das terras que hoje constituem a região do Grande ABC.

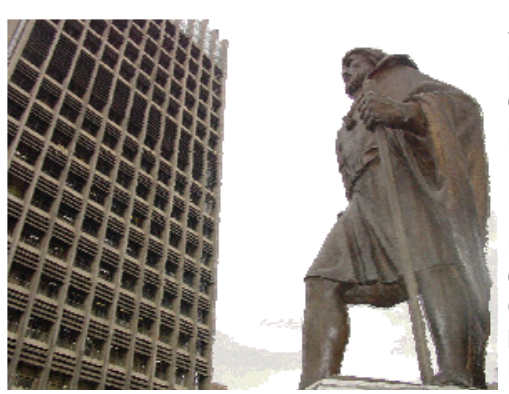
Batizou-as de Santo André da Borda do Campo e dominou-as até 1560, quando toda a população foi transferida para São Paulo de Piratininga, dos jesuítas do Pátio do Colégio, juntamente com toda sua documentação. Esta era a cidade dos personagens J oão Ramalho, Cacique Tibiriçá e sua filha Bartira. Teve pelourinho, poder constituído, atas e ficava num ponto do atual $A B C$ paulista.

Daí em diante, a história deu origem a várias versões sobre os limites da vila. A mais usual é a defendida pelo professor da USP e estudioso da história local, José de Souza Martins, na qual se afirma que situava-se na atual São Bernardo do Campo, na embocadura do córrego da Borda do Campo com o Ribeirão dos Meninos, junto à avenida Senador Vergueiro, onde existiu a empresa Villares e hoje encontra-se o Carrefour.

A Vila de Santo André da Borda do Campo deve ser lembrada por sua importância histórica no planalto e como uma referência do quinhentismo. Nada tem a ver, no entanto, com a segunda cidade, o Município de Santo André dos dias atuais.

Na segunda etapa, século XVIII, fixa-se na antiga vila a sede da fazenda dos benedetinos.

Santo André de hoje nasceu no século XIX, com a passagem da Estrada de Ferro São Paulo Railway, a SPR ou Inglesa, que começou a ser construída em 1860. No ano seguinte, começou a ser formado o primeiro povoado do atual território de Santo André, denominado Alto da Serra ou Vila de Paranapiacaba, que pode ter sua fase inicial dividida em três partes: 1861, data do início da formação da Vila Velha; 1862, ano em que se inicia a formação da parte alta (morro); 1898, início da formação de Vila Nova.

O atual centro histórico de Santo André nasce em 1867, a partir de um povoado formado muito lentamente ao redor da estação férrea São Bernardo, inaugurada naquele ano e que somente nos anos 30 deste século viria a se chamar Santo André.

Consta que houve muitas manifestações solicitando a transformação da vila em município, até que em 12 de março de 1889, um ato do presidente da província de São Paulo, Pedro Vicente de Azevedo, formaliza a criação do município de São Bernardo (correspondente à área de toda a vila - hoje ABC). A instalação oficial deu-se a 11 de maio de 1890, por força de um requerimento de autoria do Coronel Oliveira Lima, Sr. Flaquer (então futuro senador), Padre Lustosa e vários outros moradores. 
A denominação Santo André, em alusão a antiga e desaparecida vila de Santo André da Borda do Campo foi retomada apenas em 1910. O atual município de Santo André recebe o nome oficial em 1938. A comemoração do aniversário é em 8 de abril, que foi a data da instalação oficial da vila.

O Conselho de Intendência nomeado para exercer provisoriamente a administração municipal era composto por: Oliveira Lima, Francisco J osé da Silva e J osé Dal Zotto, este nomeado como primeiro intendente municipal, cargo similar a prefeito. A Câmara Municipal foi instalada em 29 de setembro de 1892, quando tomaram posse os primeiros vereadores.

\section{José Dal Zotto O Primeiro Prefeito}

Pouco se sabe sobre Dal Zotto.Era imigrante italiano e chegou a São Bernardo em 1878. Era filho legítimo de Ângelo Dal Zotto e Maria Dal Zotto, casado com Giuseppina Dal Zotto. Era negociante (comerciante). Exerceu a Intendência com 38 anos e permaneceu no cargo até 27 de março de 1892 . Faleceu em 10 de Janeiro de 1897 e foi sepultado na quadra 7, sepultura perpétua 23, do Cemitério Municipal (hoje da Vila Euclides), em São Bernardo. A sepultura foi cedida graciosamente pela Câmara Municipal.

Nenhum dos trabalhos sobre a história local cita o nome de J osé Dal Zotto, no caso, NOSSO PRI MEI RO PREFEI TO.

\section{Desenvolvimento Econômico}

A Freguesia de São Bernardo criada em 1812, abrangia, praticamente, toda a área do atual ABC e sempre teve sua sede junto ao velho Caminho do Mar, depois Estrada do Vergueiro e hoje rua Marechal Deodoro, em São Bernardo. A Freguesia foi elevada a município autônomo em 12 de março de 1889, sempre abrangendo toda a região do ABC. A Estação São Bernardo serviu, a princípio, à sede dessa Freguesia, hoje centro de São Bernardo do Campo, a oito quilômetros de distância.

O Bairro da Estação, à época da criação do Distrito de Santo André, já se destacava como o principal polo de industrialização do Município de São Bernardo. Atraía, ao mesmo tempo, fábricas de várias modalidades e um operariado vindo basicamente do interior do Estado. Também atraía muitos moradores da Vila de São Bernardo, em sua maioria italianos, interessados em melhores condições de trabalho no parque fabril que se formava.

A proximidade com a estação ferroviária, as terras planas ao longo do Vale do Tamanduateí, os estímulos fiscais, a facilidades de comunicação com a Baixada Santista e Capital foram alguns dos fatores que podem explicar o rápido crescimento do parque industrial de Santo André, que, em poucos anos, passou a ser a maior força econômica da região, seguido por São Caetano (também servido por estação ferroviária), e só depois pela Vila de São Bernardo, que continuava sendo a sede do Município.

\section{Limites e Abrangência}

Hoje o município de Santo André corresponde ao espaço central do antigo Bairro da Estação, às áreas de Utinga e Capuava e à vasta área do setor de mananciais da região Sudeste da Grande São Paulo, incluindo Paranapiacaba, Campo Grande e 18 loteamentos além da represa Billings.

Historicamente, somente em 1989 a Prefeitura assumiu, na prática, a área de mananciais, criando posteriormente o Escritório Regional da área de Mananciais, com sede no parque Represa Billings-gleba 2, inaugurado em 24 de Fevereiro de 1991, e sub-sede em Paranapiacaba, inaugurada em 8 de Março do mesmo ano.

Hoje, Santo André tem consciência de que seu território não se limita à sede e ao Distrito Capuava. Há um avanço para fora do eixo do vale do Tamanduateí, atingindo as áreas de mananciais, onde a cidade incorpora e administra bairros ao longo da represa Billings, entre os quais o Parque Represa Billings, Jardim e Parque das Graças, Jardim J oaquim Eugênio de Lima, Rio Pequeno etc, atingindo os antigos Campo Grande e Paranapiacaba. Os escritórios da área de mananciais mostram, claramente, que Paranapiacaba, por exemplo, é Santo André, como o são os bairros do porte de uma Vila Bastos, ou Parque das Nações.

Santo André, portanto, comemora, anualmente, em 8 de abril, o aniversário da instalação oficial da Vila de Santo André da Borda do Campo e não do atual Município. Isto porque a vila quinhentista de João Ramalho, que foi formada em 1550 e oficializada em 8 de abril de 1553, chegou ao fim em 1560, quando seus moradores e autoridades transferiram-se daqui para o Pátio do Colégio, na São Paulo de Piratininga;

\section{Criações e Desmembramentos}

Durante seis anos (1938-1944) todo o ABC se chamou Santo André. Em 1944 o então Distrito de São Bernardo (incluindo Diadema) obteve a emancipação político-administrativa, separando-se do Município de Santo André e sendo instalado em 1o de janeiro de 1945 com o nome de São Bernardo do Campo. Em 1948 foi a vez de São Caetano, que 
separava-se surgindo o C de ABC, São Caetano do Sul. Em 1953 foi a vez de Mauá e Ribeirão Pires (incluindo Rio Grande, atual Rio Grande da Serra) obterem suas independências.

1812 - Foi criada a Freguesia de São Bernardo, por aprovação régia do bispo diocesano e por alvará de 12 de outubro. A Freguesia, espécie de distrito de São Paulo, abrangia área que não tinha limites exatos. Não equivale ao território atual da Região do Grande $A B C$, pois dela não fazia parte o bairro rural de São Caetano.

1890 - Foi instalado o Município de São Bernardo, abrangendo toda a área da atual Região do Grande ABC, com sede em São Bernardo.

1896 - Criação do Distrito de Paz de Ribeirão Pires (incluindo os atuais Municípios de Ribeirão Pires e Rio Grande da Serra, parte de Mauá e o atual Distrito de Paranapiacaba).

1907 - Criado o Distrito de Paranapiacaba.

1910 - Criado o Distrito de Santo André (incluindo o atual Município de Santo André, São Caetano e parte de Mauá).

1916 - Criado o Distrito de São Caetano.

1934 - Criado o Distrito de Mauá.

1938 - O Município de São Bernardo passou a denominar-se Santo André. O Distrito Sede do Município passa a ser o Distrito de Santo André, englobando o Distrito de São Caetano, mantendo as demais divisas distritais.

1944 - O Distrito de São Bernardo é elevado à Município com a denominação de São Bernardo do Campo. A instalação do novo Município ocorreu em 1 ㅇ de janeiro de 1945.

1948 - O subdistrito de São Caetano é elevado à condição de Município com a denominação de São Caetano do Sul.

1953 - O Município de Santo André, inicialmente termo da Comarca de São Paulo, obteve pela Lei no 2.420 de 18/12/1953 sua autonomia jurídica, criando assim a Comarca de Santo André.

1954 - Os distritos de Mauá e Ribeirão Pires (incluindo o atual Município de Rio Grande da Serra), são elevados à condição de Município.

1958 - É criado o Município de Diadema.

1963 - É criado o Município de Rio Grande da Serra.

1985 - Em parte da área do 2o Subdistrito é criado o Distrito de Capuava.

\section{Prefeitos de Santo André}

\begin{tabular}{ll|}
\hline \multicolumn{1}{|c|}{ Mandato } & \\
janeiro de 2005 a 2008 & João Avamileno - PT \\
janeiro de 2002 a 2004 & João Avamileno - PT \\
\hline 2001 a janeiro de 2002 & Celso Daniel - PT \\
1997 a 2000 & Celso Daniel - PT \\
1993 a 1996 & Newton da Costa Brandão - PTB \\
1989 a 1992 & Celso Daniel - PT \\
\hline 1983 a 1988 & Newton da Costa Brandão - PTB \\
\hline 1978 a 1982 & Lincoln dos Santos Grillo - MDB/PMDB \\
\hline 1973 a 1977 & Antonio Pezzollo - ARENA \\
\hline 1968 a 1972 & Newton da Costa Brandão - ARENA \\
\hline 1964 a 1967 & Fioravante Zampol - ARENA \\
\hline 1964 & Lauro Gomes de Almeida - PSD \\
\hline 1962 a 1963 & Clovis Sidney Thon - UDN \\
\hline 1961 & José Silveira Sampaio - PRP \\
\hline
\end{tabular}




\begin{tabular}{|ll|}
\hline 1960 & Oswaldo Gimenez - PRP \\
\hline 1956 a 1959 & Pedro Dell ‘ Antonia - PTB \\
\hline 1952 a 1955 & Fioravante Zampol - PSP \\
\hline 1951 & Francisco A. A. Barone - PDC \\
1948 & Antonio Fláquer - PDC/PSP \\
\hline 1947 & $\begin{array}{l}\text { Alfredo Maluf * (Armando Mazzo foi cassado pelo Supremo Tribunal } \\
\text { Eleitoral antes de tomar posse) }\end{array}$ \\
\hline 1940 & José de Carvalho Sobrinho \\
\hline 1938 & Décio de Toledo Leite \\
\hline 1934 a 1937 & Felício Laurito \\
\hline 1933 & Justino Paixão \\
\hline 1931 & Armando Arruda Pereira \\
\hline 1930 & Armando Setti \\
\hline $1928 ; 1926 / 27 ; 1923 / 24 ; 1920 / 22 ;$ & Saladino Cardoso Franco \\
$1916 / 19$ e $1914 / 15$ & Alfredo Luiz Fláquer \\
\hline 1908 a 1910 e 1911 a 1913 & João Batista de Oliveira Lima \\
\hline 1905 a 1907 & Agenor de Camargo \\
\hline 1896 a 1897 e 1898 a 1904 & Capitão J osé de Oliveira Cata Preta \\
\hline 1892 a 1896 & João do Prado \\
\hline 1889 a 1891 & \\
\hline
\end{tabular}

Disponível em http://www.cmsandre.sp.gov.br/legislativo/historia.htm Acesso em 17 mai. 2010. 


\section{ANEXO 3. SANTO ANDRÉ, CAMINHOS PERCORRIDOS - MUSEU DE SANTO ANDRÉ Dr. OCTAVIANO GAIARSA}

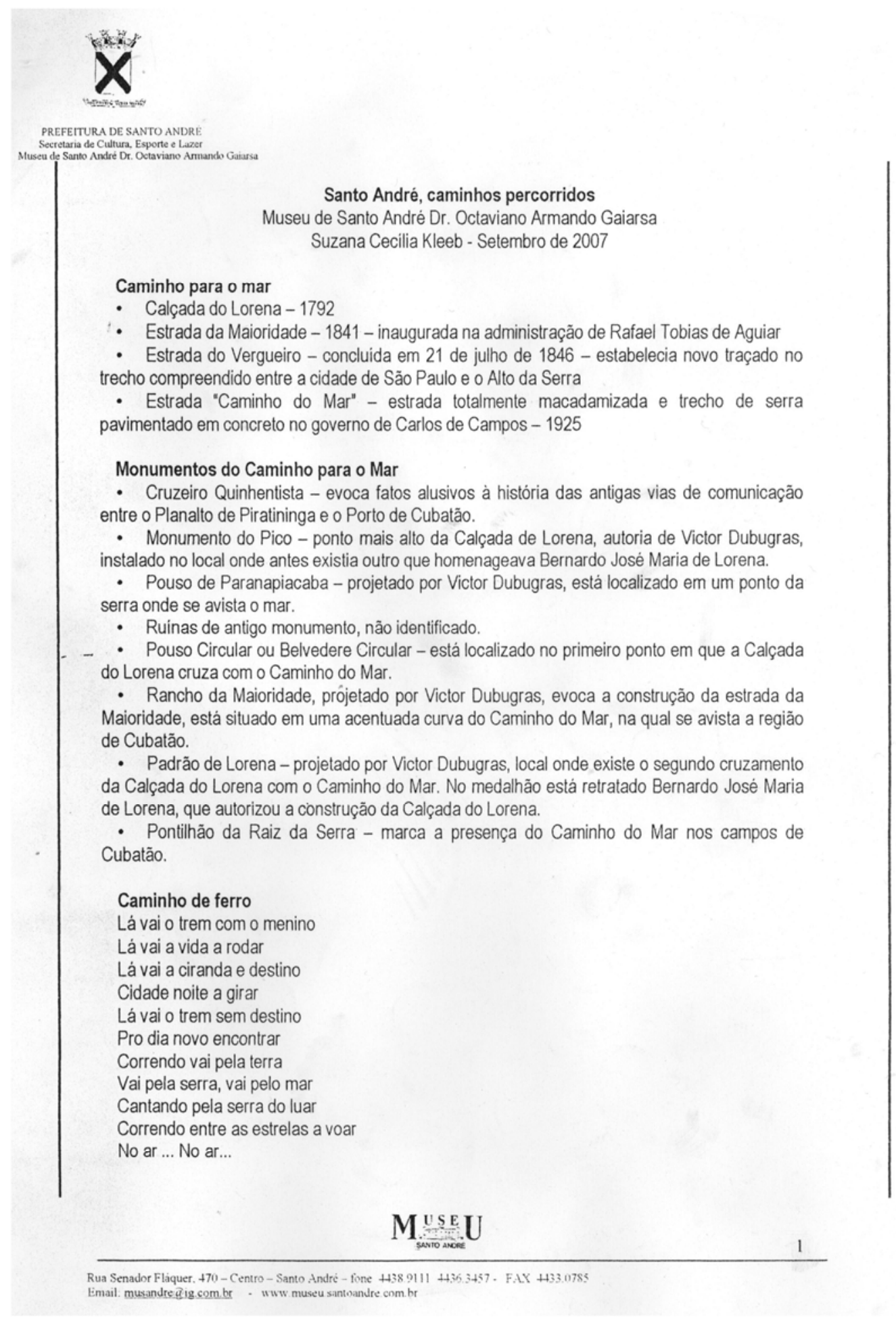




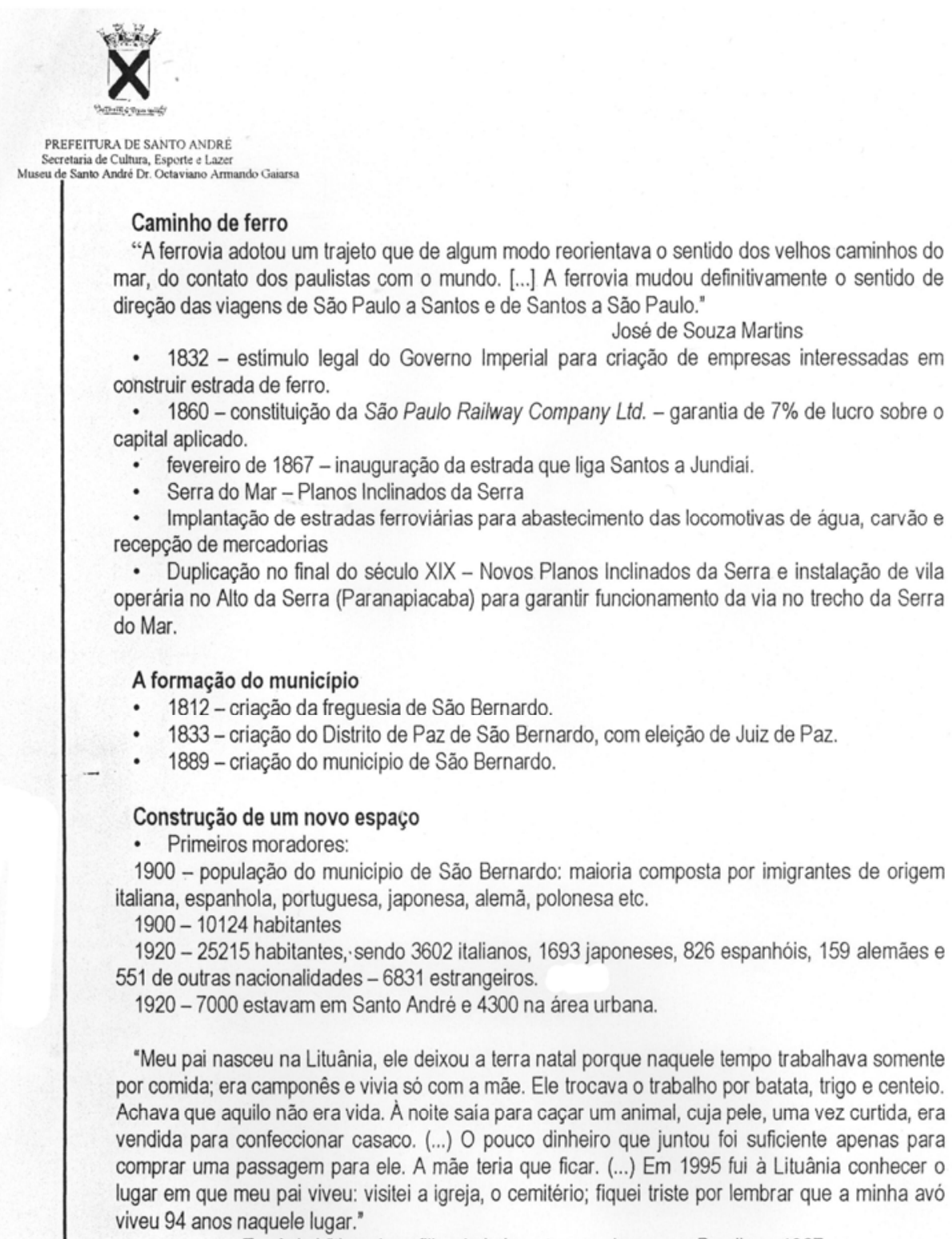

"A ferrovia adotou um trajeto que de algum modo reorientava o sentido dos velhos caminhos do mar, do contato dos paulistas com o mundo. [...] A ferrovia mudou definitivamente o sentido de direção das viagens de São Paulo a Santos e de Santos a São Paulo."

José de Souza Martins

- 1832 - estimulo legal do Governo Imperial para criação de empresas interessadas em construir estrada de ferro.

- 1860 - constituição da São Paulo Railway Company Ltd. - garantia de 7\% de lucro sobre o capital aplicado.

- fevereiro de 1867 - inauguração da estrada que liga Santos a Jundiai.

- Serra do Mar - Planos Inclinados da Serra

- Implantação de estradas ferroviárias para abastecimento das locomotivas de água, carvão e recepção de mercadorias

- Duplicação no final do século XIX - Novos Planos Inclinados da Serra e instalação de vila operária no Alto da Serra (Paranapiacaba) para garantir funcionamento da via no trecho da Serra do Mar.

\section{A formação do municipio}

- 1812 - criação da freguesia de São Bernardo.

- 1833 - criação do Distrito de Paz de São Bernardo, com eleição de Juiz de Paz.

- 1889 - criação do municipio de São Bernardo.

\section{Construção de um novo espaço}

- Primeiros moradores:

1900 - população do municipio de São Bernardo: maioria composta por imigrantes de origem italiana, espanhola, portuguesa, japonesa, alemã, polonesa etc.

1900 - 10124 habitantes

1920 - 25215 habitantes, sendo 3602 italianos, 1693 japoneses, 826 espanhóis, 159 alemães e 551 de outras nacionalidades -6831 estrangeiros.

1920 - 7000 estavam em Santo André e 4300 na área urbana.

"Meu pai nasceu na Lituânia, ele deixou a terra natal porque naquele tempo trabalhava somente por comida; era camponês e vivia só com a mãe. Ele trocava o trabalho por batata, trigo e centeio. Achava que aquilo não era vida. Ȧ noite saia para caçar um animal, cuja pele, uma vez curtida, era vendida para confeccionar casaco. (...) O pouco dinheiro que juntou foi suficiente apenas para comprar uma passagem para ele. A mãe teria que ficar. (...) Em 1995 fui à Lituânia conhecer 0 lugar em que meu pai viveu: visitei a igreja, o cemitério; fiquei triste por lembrar que a minha avó viveu 94 anos naquele lugar."

Eugênia Vitkauskas, filha de imigrante que chegou ao Brasil em 1927.

\section{$\mathrm{M}$}




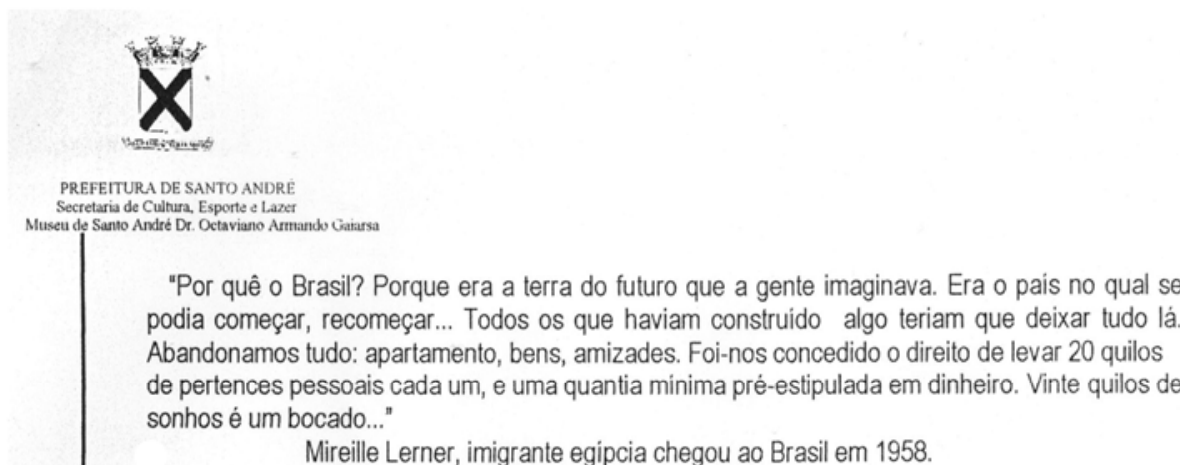

Mireille Lerner, imigrante egipcia chegou ao Brasil em 1958.

\section{Construção de um novo espaço}

- Primeiras indústrias:

- 1885: Silva \& Seabra Cia - fábrica de tecidos;

- 1889: Fábrica de Casemiras Bergman,Kowarick \& Cia;

- 1897: Companhia Streiff - fábrica de móveis.

Decreto de isenção de impostos durante $1^{\circ}$ ano de atividade - 1894

\section{Construção de um novo espaço}

Indústria - primeiros tempos:

- Fábricas - de bebidas de Marcos Cereja (1904), de meias de Oswaldo Zanotto (1907), de Móveis Irmãos Pezzolo (1911), de Móveis e Serraria Catatruzzi (1911), de Tecidos Zanolli, Costa \& Cia (1913), Fábrica de Adubos Quimicos Fernando Hachradt \& Cia (1918), Cia Rhodia Brasileira - lança perfume e produtos quimicos (1919).

\section{Construção de novas relações}

"os salários que atingiam $170 \$ 000$ (cento e setenta mil réis) mensais foram reduzidos para $90 \$ 000$ (noventa mil réis); a jornada de trabalho iniciava às 5:30 horas da manhã e estendia-se até às 18:30 horas, com uma hora de almoço; a produção diária deveria ser de 40 metros de pano, sob pena de demissão sumária; na tinturaria, 150 operários, na maioria crianças, trabalhavam com ácidos e tinta de água a 50 graus, em uma sala com apenas quatro janelas; o armazém da empresa que fornecia mantimentos para os operários, através de créditos, tinha preços muito elevados e os trabalhadores com seus baixos salários, acabavam ficando presos à fábrica, pendurados por empréstimos para os aluguéis e as contas do armazém."

Referente à greve de 1906 na Fábrica de Tecidos Ipiranquinha, Aloisio Mercadante Oliva, Imagens da Luta.

\section{Construção de novas relações}

- 1906 - ano de greves entre operários de diversas áreas e ferroviários por jornada de trabalho de oito horas;

- 1907 - greve no municipio de São Bernardo - vitória com jornada semanal de 48 horas, e criação da Liga Operária de São Bernardo, de inspiração anarquista.

Construção de um novo espaço

- 1908 - criação do Cemitério de Santo André.

- 14.12.1910 - criação do Distrito de Paz de Santo André, através da lei estadual $n^{\circ} 1222^{a}$.

- 1912 - criação do Serviço de Água e Esgotos. A primeira rede de água e esgoto de Santo André foi entregue em maio de 1914. 


\section{$x$}

PREFEITURA DE SANTO ANDRE

- 1912 - criação da Santa Casa de Misericórdia, mantida pela Irmandade de Misericórdia. composta por pessoas ilustres da cidade

- 25.03.1914 - inauguração da Paróquia de Santo André.

- 16.07.1914 - instalado o I Grupo Escolar de São Bernardo

\section{Construção de um novo espaço}

- 31.05.1914 - inaugurado o Matadouro Municipal.

- 1919 - pedra fundamental para a construção da Paróquia de Nossa Senhora do Carmo.

- Atividades para além da indústria: secos e molhados (farinhas, grãos, café, óleos, bebidas etc.), louças, remetente (transportador), ferreiro, restaurante, sapateiro, ferragens, fazendas e armarinhos, calçados, padaria, olaria, açougue, bilhar, barbeiro, carpinteiro etc.

\section{A cidade cresce}

\section{Década de 1920: 85 empreendimentos industriais.}

Entre elas: Companhia Lidgerwood do Brasil (1920), Fichet, Schwartz \&Hautmont (1923), Companhia Nacional de Cobre - Conac, depois Pirelli (1924), Atlantis Brasil (1924), Fábrica de Móveis Artisticos Gianoglio (1924), Fábrica de Calçados Antonio Galuzzi (1926), Cia Brasileira de Sedas Rhodiaseta (1929)

Olarias - Cerâmica Santo André - N. Dale \& Caiuby (1922), Cerâmica Klaussner (1922)

Distritos de Santo André e São Caetano : "centros industriais de primeira grandeza, pois - possuiam fábricas de tecidos, móveis, adubos, produtos quimicos, louças, oficinas metalúrgicas, além de fábricas 'menores'. "FCMSB : Relatório da Comissão de Melhoramentos de São Bernardo, 28/03/1928.

\section{A cidade cresce}

- Década de 1920

- primeiros auto-ônibus que ligavam o municipio a São Paulo, que complementavam o itinerário dos trens:

- linha de bondes - Empreza Immobiliaria São Bernardo.

- 1925 - 350 veiculos particulares, entre carga, aluguel ou de condução pessoal, 6 motocicletas.

- 1926 - 19 veiculos identificados como auto-ônibus.

- Final década de 1920 - linhas que atendiam bairros mais distantes: Santa Terezinha, Vila Metalúrgica e, mais tarde Parque das Nações, Camilópolis, Vila Guarará e Vila Luzita.

- Década de 1930 - 70 ônibus em todo o municipio.

- Década de 1940 - ônibus a gasogênio.

\section{Amadurecimento de novas relações}

- Década de 1930 - comunismo na luta por melhores condições de trabalho.

- Pós - Revolução de 1930 - algumas conquistas: a CLT, o salário mínimo e a Justiça do Trabalho.

- Implantação de estrutura sindical corporativista, atrelada e dependente ao Estado.

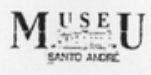




\section{$x$}

PREFEITURA DE SANTO ANDRE

- $\quad A B C$ - periodo de reorganização do movimento e das lutas sindicais, processo de formação dos sindicatos - Sindicato dos Marceneiros (1932), Sindicato dos Têxteis (1932), Sindicato dos Químicos (1938).

- Sindicato dos Metalúrgicos - fundado em 23/09/1933.

- 1935 - greve por melhores salários na Pirelli, que se expandiu entre os químicos e tecelões.

Greves intensas até fim da ditadura de Getúlio Vargas, 1945.

- 1942 - fundação da Cooperativa de Consumo dos Trabalhadores Sindicalizados, resultando em ampla campanha pró-sindicalização de trabalhadores, fortalecimento dos sindicatos.

\section{Vida de Sindicato}

"É ai que coube uma grande ilusão para aqueles que estavam na proa do movimento sindical. Inclusive, e isso eu tenho vivência, os comunistas. Achavam que com o enquadramento sindical, estava garantida a organização sindical, sem precisar mais se reunir no meio do mato. Mas, como era enquadramento sindical, e o nome diz muito bem, estava atrelado ao Ministério do Trabalho. Então, o sindicato deixava de ser livre para ser atrelado. " Armando Mazzo, Imagens da Luta, 1987.

"Não havia imposto sindical ... Então como é que a gente pagava a sede? Como é que comprava máquina de escrever? Como comprava bancos para por dentro da sede? Como se comprava escrivaninhas? Tudo isso era feito na base da coleta. Fazia pic-nic. O pessoal dava pedaço de bolo, vinho ... Eles mesmos faziam e doavam. Faziamos finanças e pagávamos a sede. - De vez em quando corria um chapéu fazendo coleta." Armando Mazzo, Imagens da Luta, 1987.

\section{Novos rumos no movimento sindical}

- Pós 1945 - Clima de liberdade, democracia e participação popular, impulsionada pela queda da ditadura de Getúlio Vargas e o final da Segunda Guerra Mundial.

- Nova investida repressora ocorreu com a intervenção do Sindicato dos Metalúrgicos de Santo André em 1947. Perseguições e caça aos comunistas eram freqüentes; mesmo simpatizantes eram presos para averiguações. A capacidade de organização dos trabalhadores ficou bastante reduzida durante os governos seguintes.

- 1947 - eleição de Armando Mazzo, operário comunista, para prefeito de Santo André, cassado antes de ser empossado.

- Intervenção no Sindicato durou até 1956

Municipio muda de nome e periodo de emancipações

- Decreto $n^{\circ} 9775$ de 30/11/1938 - transferência da sede administrativa do municipio para Santo André e conseqüente mudança do nome do municipio.

- 1944 - inicio do processo de formação dos atuais municipios do ABC com a emancipação politica de São Bernardo do Campo; 1948 - São Caetano do Sul; 1953 - Mauá e Ribeirão Pires, 1958 - Diadema de São Bernardo do Campo; 1958 - Rio Grande da Serra de Ribeirão Pires.

\section{USEU}




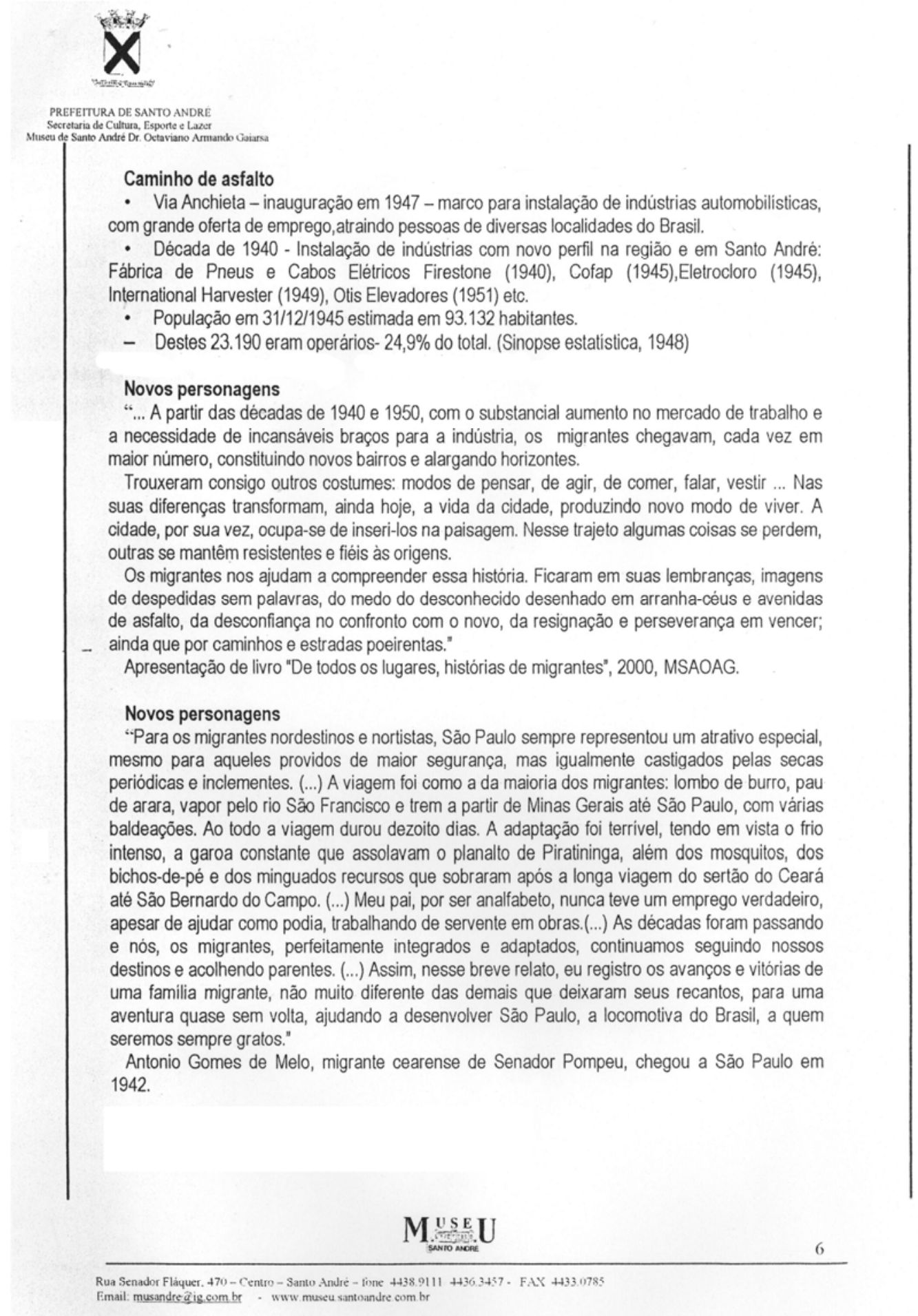




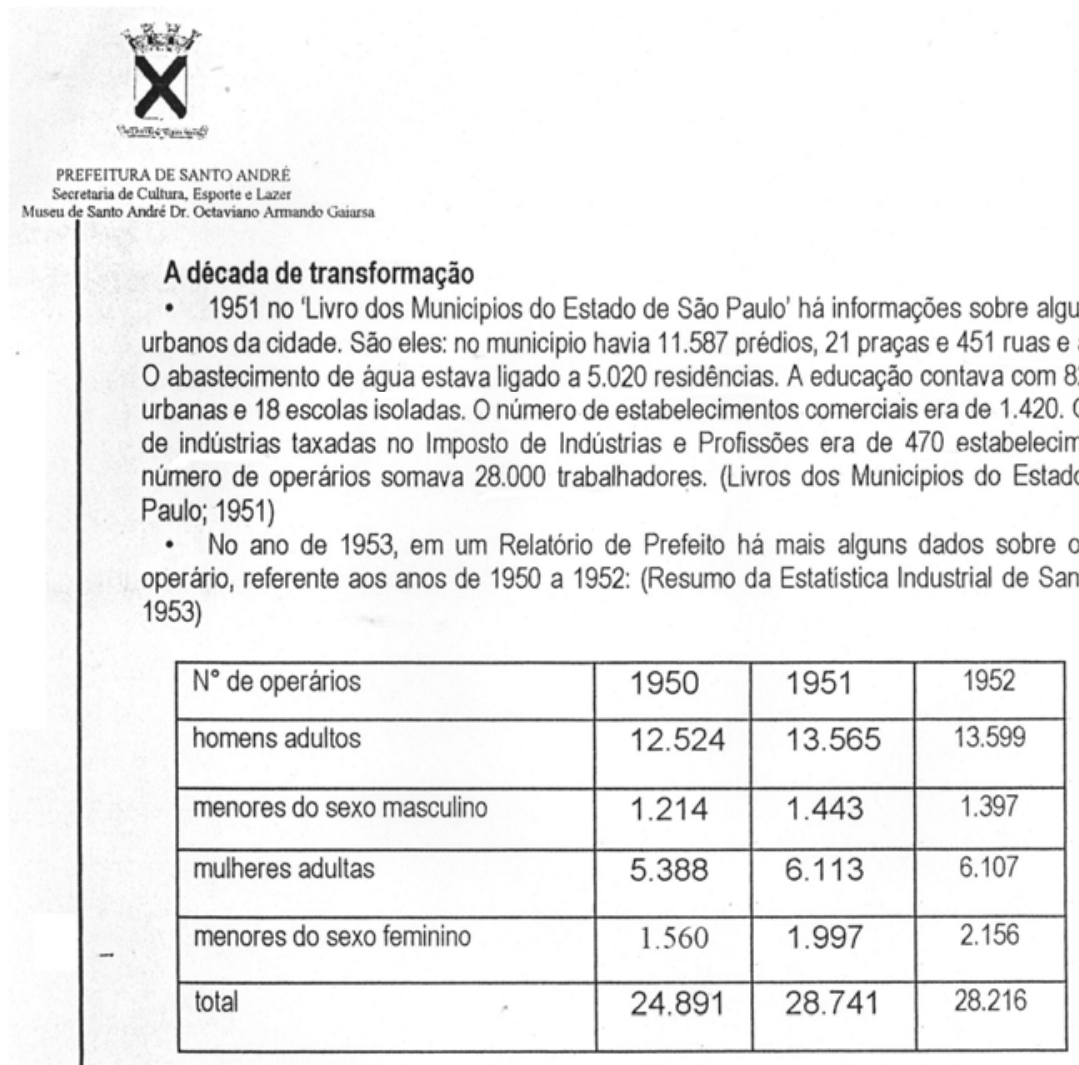

\section{A década de transformação}

- 1953 - realizada a Exposição Industrial e Comercial em comemoração ao IV Centenário de fundação da Vila de Santo André da Borda do Campo, foi realizada uma Exposição Industrial. Essa exposição abrangeu indústrias de todo o ABC.

- Foi montada em parte da praça IV Centenário, em área atualmente ocupada pelo Centro Civico de Santo André. Dali pode-se aferir que aquela que abrigava maior número de empregados era a Pirelli S.A. Cia, com 4.500 operários. Outras empresas que superavam os 1.000 empregados eram: Companhia Brasileira de Artefactos de Metais (1.000 operários), Cia Brasileira Rhodiaceta - Fábrica de Raion(2.892 operários), Companhia Quimica Rhodia Brasileira (2.245 operários), Companhia Swift do Brasil S.A. (4.056 operários), Firestone S.A. Indústria de Pneus (1.530 operários), Laminação Nacional de Metais (1.500 operários), Santo André Têxtil S. A. (2.200 operários). As demais indústrias discriminadas possuiam menos de 100 operários; exceção feita a Lanificio F. Kowarick S.A., que possuia 800 operários em suas instalações.

\section{A década de transformação}

- 1954 - inaugurada a Refinaria União, no bairro Capuava. Década de 1970 - conglomerado de indústrias quimicas formando o Pólo Petroquimico União - PqU - integrado desde a produção de produtos petroquimicos básicos até as indústrias de produtos de $2^{\mathrm{a}}$ e $3^{\mathrm{a}}$ gerações (plásticos, pvc etc)

\section{$\mathrm{M}$}




\section{$x$}

PREFEITURA DE SANTO ANDRE

\section{Para além da Indústria}

- Década de 1950 - atividades de comércio e de serviços se afirmaram na cidade - resultado : Santo André como centro de atração da região.

- Década de 1970 - redução quase que completa da dependência desses setores de São Paulo.

Trabalhadores e sindicatos

- Década de 1950 - 1960: ABC contava com cerca de 40.000 trabalhadores sindicalizados.

- Nesse periodo novas campanhas envolviam os trabalhadores do ABC: salário familia e abono de Natal (décimo terceiro salário, que só viria a ser aprovado em 1962).

Trabalhadores e sindicatos

- Década de 1960, pós-golpe de 31 de março de 1964, marcada por intervenções aos sindicatos e prisões de suas principais lideranças. 0 intuito era desarticular o movimento que voltava a se fortalecer em novas bases, com o apoio de setores da Igreja católica como a JOC Juventude Operária Católica.

- Interventores, nomeados pelo governo militar, tinham a função de afastar os trabalhadores que demonstrassem simpatia pelas antigas causas operárias. O resultado foi o esvaziamento das ações de mobilização contra o arrocho salarial, e dos próprios sindicatos, que passaram a contar com poucos sócios e assumiam posturas cada vez mais assistencialistas.

\section{- Trabalhadores e um novo sindicato}

- Sindicato dos Metalúrgicos de São Bernardo e Diadema organizou em 1977, uma campanha de reposição salarial, que desencadeou o processo de greves que tiveram inicio em 1978 e prosseguiram durante os anos iniciais da década de 1980. A situação não era pacifica, as intervenções no Sindicato dos Metalúrgicos se sucediam uma a uma. As conquistas operárias eram poucas, mas algumas delas significativas como em 1985 a conquista pelas 40 horas de jornadas semanais.

\section{Um novo sindicato}

Os sindicatos mais atuantes travavam negociações em nivel politico, estimulando além dos interesses da categoria, que os trabalhadores tivessem uma consciência mais cidadã. No $A B C$, foi criada a Câmara Regional do $\mathrm{ABC}$, na qual os sindicatos buscavam intervir junto "aos poderes públicos e aos empresários no sentido de exigir medidas que revigorassem a região como área industrial, geradora de empregos, combatendo os absurdos niveis de desigualdade social da região, materializados nos indices de analfabetismo, carências na área da saúde, déficit habitacional, violência e desamparo à criança". (www.smabc.org.br)

A população de Santo André nos últimos tempos

- $1960: 245$ mil habitantes

- $\quad 1970: 419$ mil habitantes

- 1980:530 mil habitantes

- 2000: 649 mil habitantes

Fonte:www.santoandre.sp.gov.br 


\section{$x$}

PREFEITURA DE SANTO ANDRE

Economia em Santo André nas últimas décadas

- Segunda metade da década de 1970, houve queda no ritmo de crescimento econômico e elevação do preço do petróleo. Essa situação atingiu vários setores e, especialmente no $A B C$, os setores industriais que passaram de centro do complexo metal-mecânico do pais, para uma fase de reestruturação produtiva, que tem seus primeiros sinais nesse momento.

- Década de 1980 - perda de empregos e desconcentração industrial, surgimento de novos centros de comércio e serviços diversificados, como oficinas, pequenos bazares, costura, bares etc.

- Ano 1990 e inicio do século 21, aumento de emprego informal

- O setor que mais agregou empregados foi o de serviços/profissionais liberais, com 43.303 empregados. As atividades industriais empregaram 26.868 pessoas e os empregados das atividades comerciais foram da ordem de 27.966 pessoas.

- Estabelecimentos de serviço:13.700 unidades;

- Estabelecimentos comerciais: 9.603 unidades;

- Estabelecimentos industriais : 1.058 unidades. (dados de 2003)

\section{Economia em Santo André nos últimos anos}

- A questão da reestruturação produtiva, com a introdução de inovações tecnológicas tanto nos processos como nos produtos, vem sendo discutida nos últimos anos e vem recebendo contribuições de pesquisas que apontam que em Santo André os ramos do complexo quimico e petroquimico, são os que mais têm crescido e se caracterizam como a principal fonte de arrecadação do ICMS. Em 2002, a arrecadação do ICMS chegou a $64 \%$ do total arrecadado. (Observatório Econômico; jullago/set/2003).

- Do ponto de vista do emprego, as empresas que mais empregaram foram as de serviços e comércio. Segundo dados do RAIS (Relação Anual de Informações Sociais), no ABC as indústrias de transformação empregaram $36,98 \%$, o comércio empregou $14,68 \%$ e o setor de serviços empregou 37,96\% (2003).

- Em Santo André, "ó setor de serviços tornou-se de fundamental importância no atual perfil sócio-econômico da cidade".'(Observatório Econômico; jul/ago/set/2003 : 3) Este setor respondeu por $44,58 \%$, contra $21,28 \%$ do setor de comércio e $22,90 \%$ do setor de indústria de transformação (dados de 2003).

- Discussões regionais: Câmara Regional do ABC e Consórcio Intermunicipal do ABC.

Rua Senador Flaquer +70 - Centro - Santo Andre - tone $4389111+4363457$. FAY +433 678

Rua Senaudor Flaquer. 470 - Centro - Santo Anure- tone +4589111 


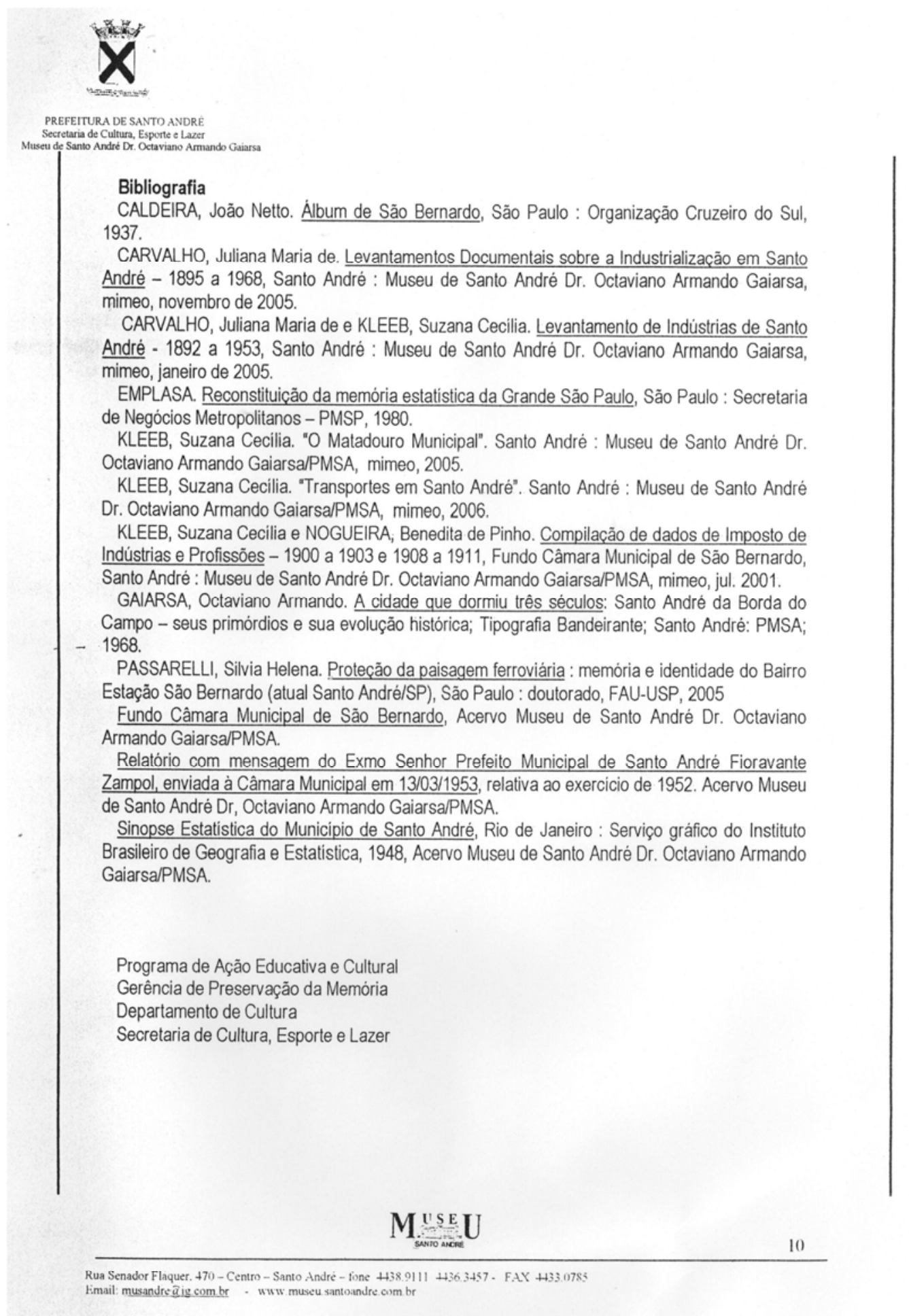


ANEXO 4. PRIMEIRO BRASÃO DE SANTO ANDRÉ.

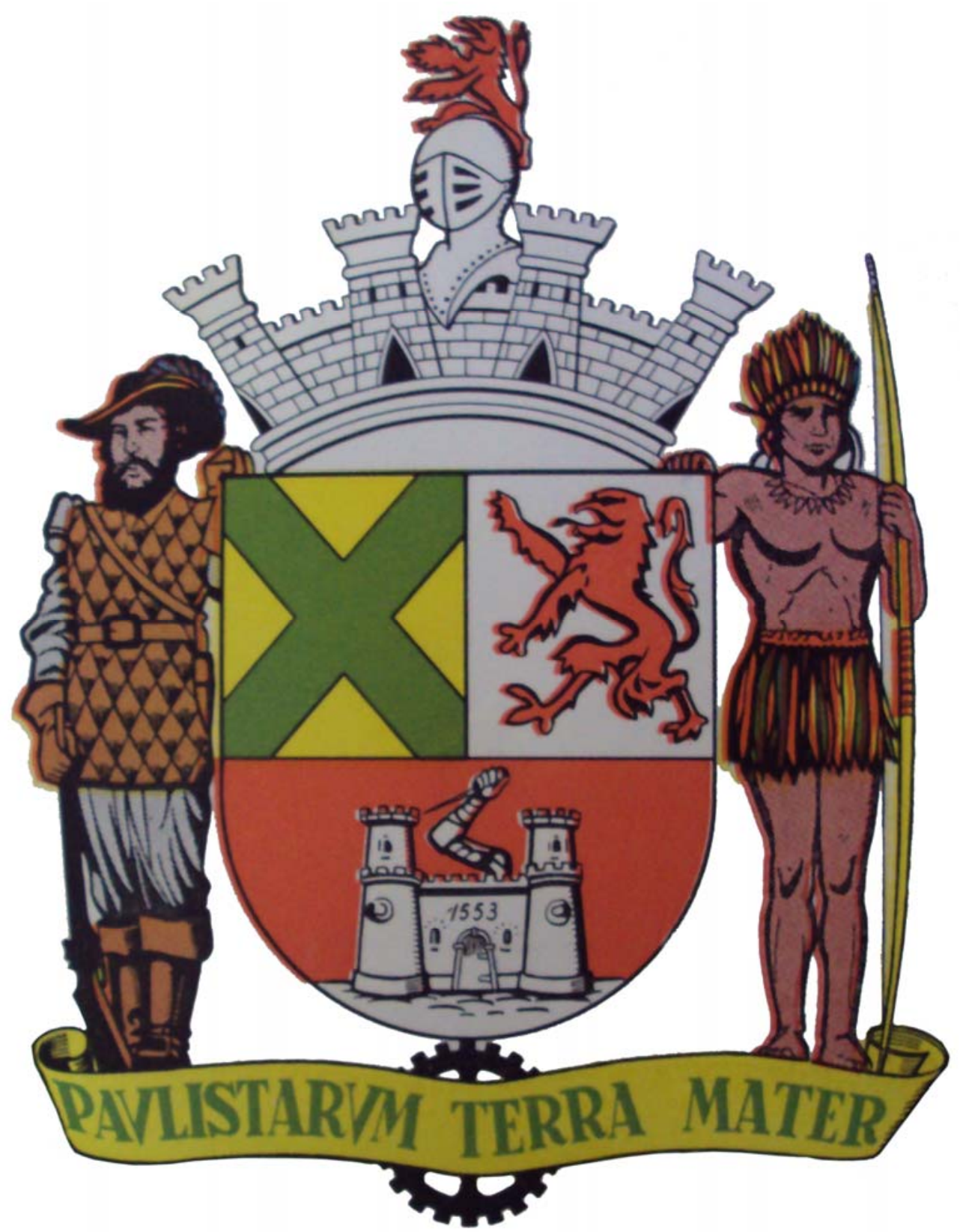

Imagem extraída da pasta 981.411 - Mapa, bandeira e brasão de Santo André Hemeroteca do Museu de Santo André Dr. Octavianno Gaiarsa 


\section{RELAÇÃO DE ILUSTRAÇÕES}

\section{RELAÇÃO DE FOTOS}

Foto 1. Montagem de fotos do Museu Dr. Octaviano Gaiarsa 28

Foto 2. Montagem de fotos sobre o Complexo Quarto Centenário 29

Foto 3. Capa do Catálogo da exposição Industrial do IV Centenário da 30 fundação de Santo André da Borda do Campo

Foto 4. Brasão de Santo André $\quad 31$

Foto 5. Bandeira de Santo André 32

Foto 6. Nome de rua com a data da fundação da cidade 36

Foto 7. Montagem de fotos da Estátua João Ramalho no paço municipal de $\mathbf{4 2}$ Santo André

Foto 8. Montagem de fotos - Parque e vila João Ramalho 42

Foto 9. Av. João Ramalho 43

Foto 10. E.C. Santo André 43

Foto 11. Montagem de fotos com os nomes de ruas dos personagens 45 quinhentistas ligados a João Ramalho

Foto 12. Hospital Bartira $\quad 46$

Foto 13. Montagem de fotos com nomes de bairros dos personagens 46 quinhentistas ligados a João Ramalho 


\section{RELAÇÃO DE FIGURAS}

Figura 1. Ruínas de Santo André da Borda do Campo

Figura 2. Logotipo do E. C. Santo André

Figura 3. Mascote do E. C. Santo André

Figura 4. Jornal A gazeta - 9 de julho de 1557 


\section{RELAÇÃO DE MAPAS}

Mapa 1. Contextualização de Santo André no Estado de São Paulo e no Brasil.

Mapa 2. Principais vias de Santo André.

Mapa 3. Povoamento do território paulista no século XVI.

Mapa 4. A freguesia de São Bernardo em 1832

Mapa 5. Oficialização do município de Santo André em 1938

Mapa 6. Núcleos urbanos e povoamento no município de São Bernardo em 1906

Mapa 7. Estradas, caminhos e ferrovias no município de São Bernardo 1906

Mapa 8. Santo André em 1954

Mapa 9. Bairros e distritos de Santo André 